RAFAEL HAMZE ISSA

O CONTROLE JUDICIAL DOS ATOS NORMATIVOS DAS AGÊNCIAS REGULADORAS

Dissertação de Mestrado

Orientador: Professor Titular Dr. Floriano de Azevedo Marques Neto

UNIVERSIDADE DE SÃO PAULO

FACULDADE DE DIREITO

São Paulo - SP

2015 


\title{
O CONTROLE JUDICIAL DOS ATOS NORMATIVOS DAS AGÊNCIAS REGULADORAS
}

Dissertação de Mestrado apresentada ao Departamento de Direito do Estado da Faculdade de Direito da Universidade de São Paulo, como requisito parcial para a obtenção do Título em Mestre em Direito do Estado, Subárea Direito Administrativo.

Orientador: Professor Titular Dr. Floriano de Azevedo Marques Neto.

\author{
UNIVERSIDADE DE SÃO PAULO \\ FACULDADE DE DIREITO \\ São Paulo - SP \\ 2015
}


Nome: ISSA, Rafael Hamze.

Título: O controle judicial dos atos normativos das agências reguladoras.

Dissertação de Mestrado apresentada ao Departamento de Direito do Estado da Faculdade de Direito da Universidade de São Paulo, como requisito parcial para a obtenção do Título em Mestre em Direito do Estado, Subárea Direito Administrativo.

Orientador: Professor Titular Dr. Floriano de Azevedo Marques Neto.

Aprovada em:

Banca examinadora:

Professor Dr.

Instituição

Julgamento

Assinatura

Professor Dr.

Instituição

Julgamento

Assinatura

Professor Dr. Instituição

Julgamento Assinatura 
Para Camila e Clara: meus amores. 
"Dado, pues, que en la teoría del Estado, lo mismo que en la ciencia del derecho y en todas las demás ciencias que no operan sólo con formas mentales desnudas de realidad, los contenidos de los conceptos no pueden derivarse del principio de la formación racional $\mathrm{y}$, por conseguiente, son irracionales, no puede haber en esas ciencias un sistema cerrado de conceptos; el contenido irracional interviene siempre, aqui, en la formación y en la estructura de las diferentes formas particulares, lo mismo que en sus relaciones recíprocas y, por esta razón, tambien en la estructura de la sistemática. No es posible, en estas ciencias, un sistema en el sentido de una definitiva fijación sistemática de las cuestiones; porque aun las mismas ciencias cambian com las aspiraciones e ideas de los hombres.

La conexión sistemática por la que la teoría del Estado, como ciencia, há de ordenar sus conocimientos no puede, pues, ser la de una concatenación lógica. Su construcción y la articulación de sus resultados serán determinadas, preferentemente, y hasta donde sea posible, por el objeto, es decir, por la relación que guardan los hechos concretos con la estructura del Estado". (Herman Heller, Toría del Estado, 1998 [trad. ed. 1934], p. $52)$. 


\section{AGRADECIMENTOS}

Apesar de a responsabilidade pelo quanto escrito no presente trabalho ser exclusivamente minha, o percurso para a elaboração dele contou com muitos colaboradores. Se não podem ser considerados como coautores, até porque não quero que sejam responsabilizados pelos erros aqui constantes - e que são muitos, reconheço -, o fato é que a dissertação de mestrado jamais poderia ter sido sem a colaboração de todos vocês a quem agradeço neste momento, seja no que se refere aos ensinamentos acadêmicos, seja no que se refere ao apoio, à força e à serenidade que me concederam no percurso que levou até o presente trabalho. Passo a listar meus credores, não do ponto de vista jurídico, mas sim moral, na esperança de um dia poder retribuir-lhes ao menos um pouco em tudo aquilo que têm me auxiliado.

À minha esposa, CAMILA, fonte de toda a minha inspiração e força nos momentos mais difíceis. Não sei o que seria da minha vida sem você, sem seu carinho, apoio, afeto e tudo aquilo que torna os nossos momentos mais comuns em especiais.

À ClARA, nossa filha, que veio para iluminar ainda mais nossas vidas, com a ternura e a doçura de uma criança muito especial. Saiba, minha filha, que cada dia é mais gostoso e gratificante ser seu pai...um dia você entenderá o que digo.

Aos meus pais PAUlo e MARIA LÚCIA. Em primeiro lugar, por terem me dado a vida, por todo o amor e carinho com que criaram a mim e à minha irmã, bem como por transmitirem o valor da educação e do estudo. Apesar de todas as dificuldades pelas quais passamos juntos, jamais permitiram que nossa educação fosse prejudicada. À minha irmã DENISE, cuja alegria contagiante me ajuda a enxergar o lado bom da vida.

Aos meus sogros José Roberto e HelenA, por suprirem minha ausência com o carinho e afeto dados à Camila e à Clara. Sem este apoio, o presente trabalho jamais teria sido possível.

Ao Professor Floriano de Azevedo Marques Neto. Em primeiro lugar, por realizar um processo seletivo de orientandos transparente e republicano, no qual a 
aprovação para uma das concorridas vagas concede a segurança e a confiança de que os aprovados estão preparados para enfrentar um duro período de estudos. Ser seu orientando foi e sempre será um grande orgulho. Em segundo lugar, pela orientação firme da presente dissertação, sempre com comentários e críticas construtivas, no sentido de tornar o trabalho melhor. A seriedade acadêmica da orientação foi algo que ficará marcado e servirá de exemplo a ser seguido na carreira acadêmica. Em terceiro lugar, por me convidar para participar dos seus projetos acadêmicos, bem como para a monitoria da graduação, oportunidades de aprendizado rico e frutífero. Para um orientando que nutre profunda admiração pelo orientador - que considera como um exemplo a ser seguido -, as oportunidades de estar próximo e de aprender com o seu mestre são sempre proveitosas e marcantes. Por fim, pela amizade e pelo apoio sempre firme nestes mais de três anos de convívio - contando o período no qual fui seu ouvinte na pós-graduação -, bem como por todos os ensinamentos transmitidos, ao longo de todo o período, que alteraram completamente a minha forma de ver e perceber o direito administrativo. Por tudo isso, Professor, muito obrigado.

Aos Professores cujos excelentes créditos tive o prazer de cursar: CELSO Fernandes Campilongo, Maria Sylvia Zanella di Pietro, Fernando Dias Menezes de Almeida, Vitor Rhein Schirato e Ronaldo Porto Macedo Júnior. Os ensinamentos transmitidos, além de devidamente anotados em cadernos, estão gravados na memória. Também agradeço aos Professores VITOR RHEIN SCHIRATO e Jean Paul Cabral Veiga da Rocha pelas importantes críticas e comentários que fizeram quando da realização da banca do exame de qualificação.

No período em que cursei os créditos do Mestrado, além de muito estudo e dedicação, tive a sorte de conhecer amigos com quem dividi as inseguranças, as esperanças, bem como pude aprender e refletir sobre o Direito. A CARLOS EDUARDO Begamini Cunha, Alexandre Jorge Carneiro da Cunha Filho, Guilherme Frederico Dias Reisdorfer, Rafael Roque Garofano, Camila Viana, Mariana Chiesa, Lívia Wanderley, Marina Zago, Marina Cardoso, entre tantos outros, ficam aqui meus sinceros agradecimentos por tornarem a vivência acadêmica mais agradável. 
Três amigos da Academia merecem destaque. JulianA BONACORSI DE PALMA, que tive o privilégio de conhecer e de absorver conhecimentos semanais em um grupo de pesquisa coordenado pelo Professor Floriano e no qual ela chefiava os pesquisadores. Com a Juliana, aprendi não apenas a realizar pesquisas acadêmicas em grupo e a superar os meus limites no estudo e na busca pelo desenvolvimento do direito adminitrativo, mas principalmente que seriedade acadêmica, empenho e genialidade não elidem a simplicidade, a humildade e a vontade de ajudar. A ela devo muito da minha formação acadêmica e do contato com diversos autores que são citados na presente dissertação. JOSÉ JAIR MARQUES JÚNIOR, companheiro de créditos e de monitoria, sempre disposto a conversar e refletir a respeito das matérias e das questões de seminário aplicadas aos alunos. Além disso, tem sido um importante apoio na empreitada acadêmica e nos desafios profissionais. ANDRÉ RosilHo, com quem tenho tido o privilégio de aprender a cada dia mais, tanto com seus artigos, quanto com nossas conversas e reflexões. Sua amizade sempre firme tem sido fundamental para que eu possa seguir em frente.

Ainda no que se refere à empreitada acadêmica, devo um especial agradecimento à Professora Christianne DE CARvalho StropPa, que me deu a primeira oportunidade de conhecer o mundo acadêmico, aceitando-me como seu monitor na graduação da PUC-SP, nos idos de 2007. O período de quatro anos durante os quais tive o prazer de a acompanhar foram de profundo aprendizado $\mathrm{e}$ amadurecimento. Pela oportunidade de aprendizado, pela amizade e pelo apoio ficam aqui os meus agradecimentos. Agradeço também aos amigos que cultivei em tal período, Juliana Bastos e Pedro Ivo, pelo constante incentivo e troca de ideias a respeito do direito administrativo.

No campo da advocacia, devo um especial agradecimento aos meus ex-colegas do escritório Camilo Advogados. Ao Ruy Pereira Camilo Júnior, por ter me dado a oportunidade de, mesmo inexperiente, fazer parte do corpo de advogados do seu escritório, bem como por toda a paciência e afeto com que me construiu como advogado. As lições aprendidas ao longo de seis anos de convívio são inesquecíveis e me marcaram profundamente do ponto de vista profissional e pessoal. Sua imensa capacidade e conhecimentos acadêmicos somente não são maiores que sua generosidade para emprestar livros, mesmo raros, e discutir os assuntos jurídicos. Ao Michel BRAZ DE OLIVEIRA, com quem aprendi praticamente tudo o que sei a respeito de licitação e 
improbidade administrativa, pela amizade diária cultivada no escritório e por todos os ensinamentos transmitidos ao longo dos anos. Ao ANDRÉ Luís IERA LEONARDo DA SILVA, que vi entrar no escritório como estagiário e hoje já se mostra um advogado cada vez mais completo, pela amizade e pelo apoio constantes para a elaboração do presente trabalho. Aos demais integrantes do escritório Denise, Helena, Tatiana, Jefferson, Anselmo, Cristiano, Wil, Elisete, Márcia, Cleonice e, principalmente, Marcos (Marquito), fica meu agradecimento por fazerem um clima de trabalho tão agradável e único.

Aos meus colegas na nova casa, o Lacaz Martins, Pereira Neto, Gurevich E Schoueri Advogados. Aqui, a lista é grande. Aos sócios-fundadores RicARdo Lacaz Martins, Miguel Pereira Neto, Luís Eduardo Schoueri e Eduardo IsAíAs GUREVICH, pelo constante estímulo aos advogados do escritório para que realizem trabalhos cada vez melhores e tenham crescimento profissional. Ao GUREVICH devo um agradecimento especial pela recepção calorosa, pelo apoio sempre firme para a elaboração do presente trabalho e pela preocupação com a minha adaptação ao escritório. Às sócias da área de direito administrativo, MARIA BEATRIZ CAPOCCHI Penetta (Bia), Mariana Campos de Souza e Vanessa de Sousa Rosa, pela confiança depositada e pelo apoio nas tarefas do quotidiano. Às minhas colegas de equipe: Tatiana de Souza Neves, Carolina Mosseri, Amanda Morete, Caroline Botsman Brandt, Carolina Brumati Ferreira, Camila Rodrigues da Silva, Aline Satie Okano, Natália Arantes Gonçalves Chaves, Mariana de Cássia CARLino e ANDRESA Montorso, por todo o apoio e a amizade na empreitada diária.

À BIA, devo um agradecimento especial, tanto por acreditar em mim, como me fazer perceber que é possível render mais e melhor, além de possuir um bom humor contagiante. Como ela sempre diz: "Um ótimo dia e vamos que vamos!". À TATIANA, AMANDA e NATÁLIA também devo um agradecimento especial por tornarem o dia-a-dia na advocacia mais agradável.

Aos funcionários da biblioteca do escritório, por sempre atenderem com rapidez às minhas incessantes solicitações de livros. 
Também devo um agradecimento a amigos de outras áreas do escritório: TATIANA MARA UlhÔA SCORSATO - pelas conversas a respeito do Estado enquanto indutor da economia -, Fabiana de Souza Gonçalves, Luiz Fernando Siqueira Ulhôa Cintra, Renato Vinícius de Moraes, Luiz HenRiQue SigOlo LeVy, SÉrgio Teixeira de Andrade Filho, Renato Rossato Amaral, Mateus Calicchio Barbosa, Ricardo André Galendi Júnior e Henrique Malerba Cravo. Pela amizade e companheirismo, fica aqui o meu agradecimento.

A Quem tudo devo e sempre deverei. 


\section{SUMÁRIO}

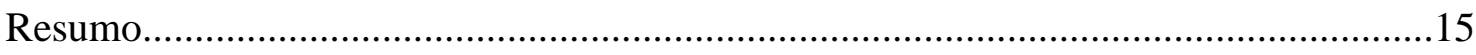

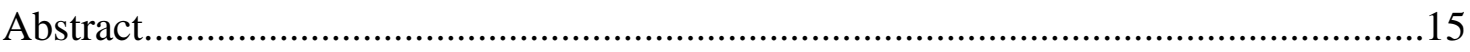

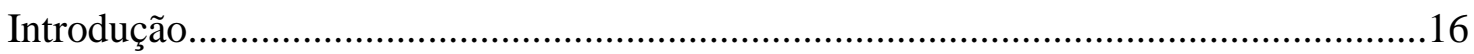

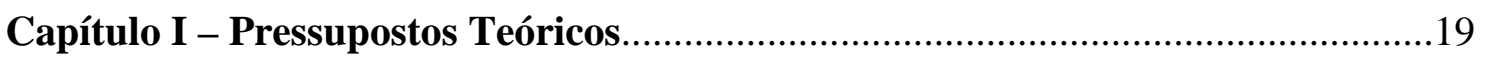

I.A - A Ideia de Separação de Poderes em Montesquieu...............................................22

I.B - Análise Evolutiva da Separação de Funções e da Legalidade................................25

I.B.1 - O Estado Liberal de Direito..........................................................................25

I.B.2 - O Estado Social de Direito de Intervenção na Economia...................................34

I.B.3 - O Estado Social de Direito de Intervenção Sobre a Economia..........................48

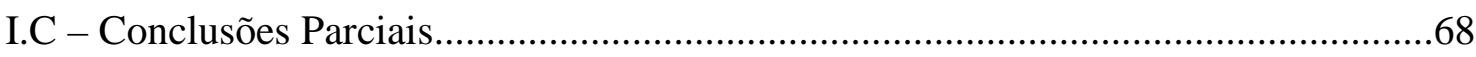

Capítulo II - A Atividade Normativa das Agências Reguladoras...........................70

II.A - A Natureza Jurídica da Competência Normativa: A Delegação Legislativa........70

II.B - A Expedição do Ato Normativo Regulatório Enquanto Atividade

Processualizada: A Legitimação pelo Procedimento................................................... 87

II.B.1 - A Legitimidade Democrática das Agências Reguladoras................................90

II.B.2.1 - Breve Panorama do Rulemaking Norte-Americano......................................94

II.B.2.2 - A Atividade Normativa das Agências Reguladoras no Direito Brasileiro: as

Pautas Procedimentais a Serem Respeitadas pelas Agências.

II.C - Os Aspectos Materiais a Serem Analisados na Expedição do Ato Normativo

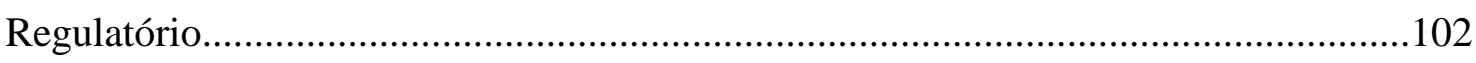

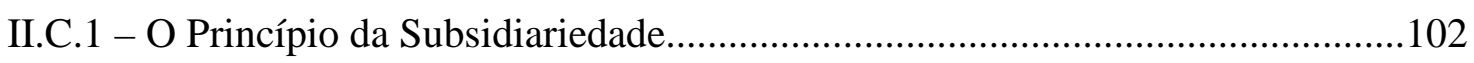

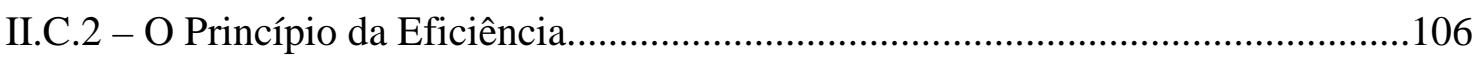

II.C.3 - Os Princípios da Razoabilidade e da Proporcionalidade..................................112

II.C.3.1 - O Princípio da Razoabilidade..................................................................... 114

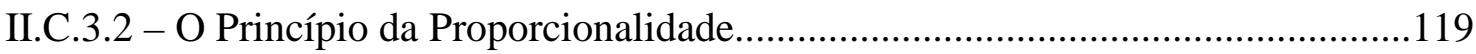

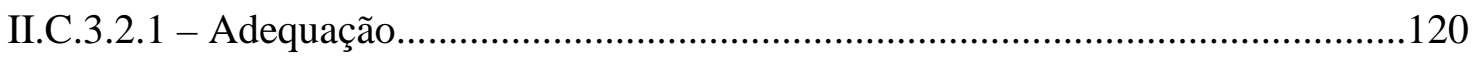

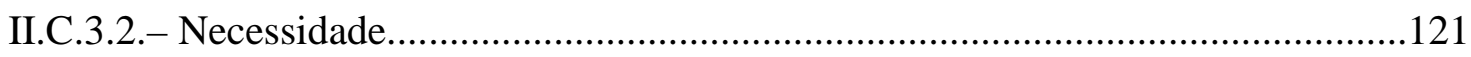

II.C.3.2.3 - Proporcionalidade em Sentido Estrito....................................................122

II.D - A Discricionariedade na Atividade Normativa Regulatória..............................122 
II.D.1 - Fundamentos da Discricionariedade e Delineamentos Gerais

II.D. 2 - A Discricionariedade na Atividade Normativa Regulatória.

.131

II.E - A Motivação de Acordo com os Elementos do Procedimento.

II.F - Conclusões Parciais.

144

\section{Capítulo III - O Controle Judicial dos Atos Normativos das Agências Reguladoras} no Brasil.

III.A - Colocação do Problema: O Judiciário Brasileiro e o Controle da Administração Pública entre a Bipolaridade e a Explosão da Conflituosidade. .146

III.B - A Legitimidade do Judiciário para o Controle de Atos Normativos Regulatórios. 156

III.C - Os Problemas Institucionais do Controle Judicial dos Atos Normativos das Agências Reguladoras. 159

III.C.1 - Os Problemas Ligados às Diferenciações entre Administração e Judiciário..160

III.C.1.1 - Imutabilidade da Coisa Julgada e Mutabilidade Técnico-Econômica das Relações do Mercado. 161

III.C.1.2 - Restrição da Visão Judicial aos Elementos do Caso e Visão Macro da Administração a Respeito do Sistema Regulado. 164

III.C.1.3 - Vedação Judicial ao non liquet e Possibilidade de Postergação da Decisão pela Agência Reguladora. 166

III.C. 2 - O Problema de Quem Realiza a Política Regulatória. .168

III.D - Entre Ativismo Judicial e Leniência com o Abuso de Poder: o Controle Judicial da Atividade Normativa das Agências Reguladoras e seus Contornos Institucionais..171 III.D.1 - O Controle Judicial sobre as Formalidades do Procedimento Regulatório....172 III.D.2 - O Controle Judicial com Relação ao Mérito do Ato Regulatório. .174

III.D.2.1 - Ainda a Questão do Controle Judicial do Mérito do Ato Administrativo...174 III.D.2.2 - Um Importante Parâmetro do Direito Estrangeiro: A Hard Look Doctrine. 179

III.D.2.3 - A Hard Look Doctrine e sua Aplicabilidade no Direito Brasileiro. .181 III.D.2.3.1 - O Controle Material da Regulação de Acordo com os Elementos do Procedimento Administrativo e com os Princípios e Postulados Incidentes Sobre a Regulação. 182

III.D.2.3.2 - O Resultado do Controle Material da Regulação. 185 
III.E. - Um Fundamental Parâmetro a ser Observado pelo Judiciário: o

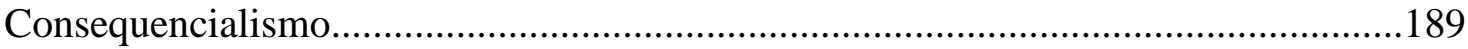

III.E.1 - O Consequencialismo: Noção Geral e sua Presença no Direito Brasileiro....190

III.E.2 - A Importância do Consequencialismo na Atividade de Controle da

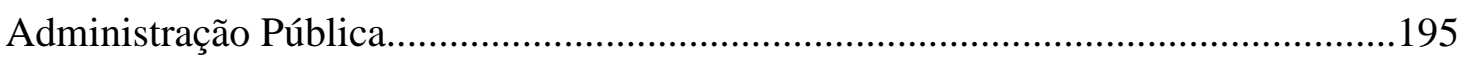

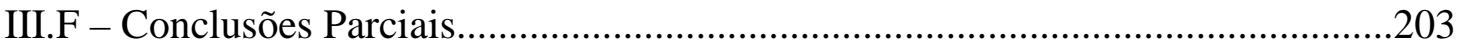

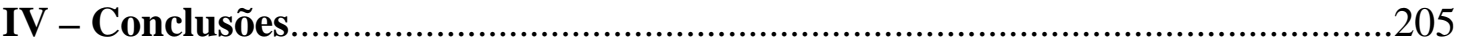

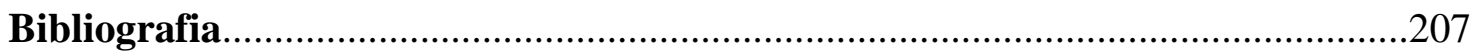




\section{RESUMO}

ISSA, Rafael Hamze. O controle judicial dos atos normativos das agências reguladoras. 221 fls. Dissertação (Mestrado) - Departamento de Direito do Estado, Faculdade de Direito, Universidade de São Paulo, 2015.

A presente dissertação possui por objeto discutir o controle judicial da atividade normativa das agências reguladoras no direito brasileiro. $\mathrm{O}$ trabalho é dividido em três partes. Na primeira, é analisa a evolução do princípio da separação de poderes ao longo dos séculos XIX e XX, bem como a receptividade dele no início do século XXI, notadamente em virtude do processo de retirada do Estado da intervenção direta na economia, como prestador de serviços aos cidadãos, e sua recolocação como regulador das atividades econômicas. Também é analisada na primeira parte como tais mudanças econômicas e sociais implicaram em uma alteração do papel do Poder Judiciário que, inicialmente criado como o menos ativo dos poderes, tornou-se órgão central para a efetivação dos direitos da democracia contemporânea. Na segunda parte, é analisada a atividade normativa das agências reguladoras, com a defesa da tese da delegação legislativa, bem como com a verificação dos requisitos procedimentais e materiais que devem ser observados pelas agências reguladoras na expedição dos atos normativos e de como tais requisitos acabam por limitar a discricionariedade dos entes reguladores. $\mathrm{Na}$ terceira parte, é feita a verificação do controle judicial da regulação, tendo como premissas a adoção pelo direito brasileiro do sistema da unidade de jurisdição e as diferenças funcionais entre o Judiciário e a Administração no estabelecimento de políticas públicas, com a defesa de que o controle judicial dos atos normativos das agências reguladoras deve se dar de modo negativo, ou seja, sem que o Judiciário possua competência para a estipulação da política regulatória a ser seguida, e de forma responsiva, ou seja, com a análise das consequências do controle judicial sobre o setor regulado, devendo o magistrado analisar não apenas os aspectos de legalidade do normativo questionado, mas também a finalidade do sistema regulado e os impactos que a decisão judicial terá sobre ele.

Palavras-chave: Agências Reguladoras - Separação de Poderes - Legalidade Delegação Legislativa - Controle Judicial - Consequencialismo. 


\begin{abstract}
$\underline{\text { ABSTRACT }}$
ISSA, Rafael Hamze. The judicial control of the regulatory agencies' normative rulings. 221 pages. Master's Degree Thesis - Department of Public Law, Faculty of Law, Universidade de São Paulo, 2015.

The object of the current thesis is to discuss the judicial control of the normative activity of the regulatory agencies according to Brazilian law. This paper is divided into three parts. At first, the evolution of the principle of the separation of powers across the Nineteenth and the Twentieth century will be analyzed, as well as the reception of such principle in the early Twenty-one century, especially due to the process of disengagement of the State from the direct intervention in the economy (as a provider of services to the citizens) and its replacement as a regulator of economic activities. Also in the first part, it will be analyzed how such economical and social changes caused a modification of the role of the Judiciary branch which, initially, was created as the less active of the State powers, becoming the central body for the effectiveness of the contemporary democracy rights. The second part analyzes the normative activity of the regulatory agencies, with the defense of the thesis of legislative delegation, as well as with the verification of the procedural and material requirements that must be observed by the regulatory agencies in the issuance of normative rulings and how such requirements end up limiting the discretion of the regulatory bodies. In the third part the verification of the judicial control of such regulation is carried out, having as its premises the adoption, by Brazilian law, of the unity of jurisdiction system and the functional differences between the Judiciary branch and the Public Administration in the establishment of public policies, being defended that the judicial control of the regulatory agencies' normative rulings must be made in a negative manner, i.e., without the Judiciary having the competence for the stipulation of the regulatory policy to be followed, as well as in a responsive manner, i.e., with the analysis of the consequences of the judicial control over the regulated sector, being the magistrate responsible for analyzing not only the aspects of legality of the questioned normative rulings, but also the objective of the regulated system and the impacts of the judicial decision on it.
\end{abstract}

Key-words: Regulatory Agencies - Separation of powers - Legality - Legislative Delegation - Judicial Control - Consequentialism. 


\section{INTRODUCÃO}

O Estado está constantemente em evolução. Sendo ele constituído, entre outros, pelo povo, à medida que a sociedade se altera, é necessário que o Estado também acompanhe a mutação, com a finalidade de manter a sua legitimidade enquanto ente soberano, o que inclui a alteração tanto de sua estrutura, quanto de suas funções.

Tal evolução do Estado e de suas instituições foi muito acentuada no decorrer do século XX, em cujo início o Legislativo despontava como o grande protagonista e que assistiu, paulatinamente, ao protagonismo do Executivo, hoje ombreado pelo Judiciário.

O fato é que as circunstâncias econômicas, sociais e políticas colocaram o Judiciário na condição de partícipe no estabelecimento e concretização do interesse público, juntamente com a Administração, uma vez que o princípio do amplo acesso à jurisdição permite que qualquer tipo de ato administrativo seja objeto questionamento judicial.

Desde a inabilitação em uma licitação pública até o manejo de recursos para a publicidade institucional, todo o tipo de ato administrativo é passível de questionamento junto ao Judiciário que, pela principiologia e pela força vinculante das normas constitucionais, possui condições, ao menos, de dizer o que não deve ser feito pela Administração.

Surge, então, a seguinte questão: em um quadro de conflituosidade social acentuada e no qual os conflitos que envolvem a Administração deixam de ser meramente calcados na relação liberdade x autoridade, mas passam a envolver políticas públicas e regulatórias e alocação de recursos, como deve ser exercido o controle judicial?

A nosso ver, tal questão impõe a análise dos fatores que levaram ao presente contexto, o que é muito bem verificado no âmbito das agências reguladoras e seu controle judicial. 
Neste sentido, o surgimento das agências reguladoras no direito brasileiro provavelmente represente uma suma das principais alterações por que passaram o Estado e o Direito nas últimas décadas. Em primeiro lugar, representa o momento de retirada do Estado da prestação direta dos serviços à população, para a utilização de mecanismos concessórios e de privatização, com a criação de diversos setores regulados, que possuem finalidades próprias e racionalidades específicas.

Ademais, os setores regulados representam a própria conflituosidade social. Cada um deles possui diversos agentes com interesses antagônicos, que lutam entre si para o atendimento de suas pretensões, o que se traduzirá na processualidade necessária à tomada de decisões por tais entes, com a necessidade de oitiva de todos os interessados de determinado setor regulado, bem como com a necessidade de que a decisão do processo reflita efetivamente os debates ocorridos no processo administrativo.

Não obstante, as agências reguladoras representam importante mecanismo para o exercício das atividades normativas pela Administração Pública, o que fez reacender o debate a respeito da delegação legislativa e dos limites da normatização pelo Executivo, notadamente em um cenário no qual a tecnicidade tende a se sobrepor ao caráter político das escolhas administrativas.

Também as agências reguladoras demonstram a limitação à discricionariedade administrativa imposta pela constitucionalização do direito, pelos princípios, pela procedimentalização da atividade administrativa e pela necessidade de motivação dos atos administrativos de modo congruente e racional.

Por fim, no que toca ao controle judicial, os debates envolvendo as agências representam, em grande medida, os debates que cercam o controle judicial de políticas públicas, ou seja, o quanto que a intervenção judicial pode auxiliar ou atrapalhar o desenvolvimento de determinado setor, bem como a efetivação dos direitos nele envolvidos. 
Para tratarmos de tal assunto, dividimos o presente trabalho em três capítulos de desenvolvimento. No primeiro, tratamos dos pressupostos teóricos, demonstrando quais as razões que levaram o Judiciário, inicialmente concebido como o mais retraído dos poderes, a hoje ombrear com a Administração Pública o protagonismo na efetivação de políticas públicas e demais questões de interesse coletivo.

No segundo capítulo, analisamos o procedimento normativo das agências reguladoras, com a finalidade de estabelecer a natureza jurídica do poder normativo conferido às agências, bem como quais são os requisitos de validade, processuais e materiais, para a expedição dos atos normativos regulatórios.

Por fim, no terceiro capítulo, tratamos do controle judicial dos atos normativos das agências reguladoras, com a finalidade de verificar até onde pode ir o Judiciário ao ser colocado diante deles, levando em conta a sua relevante função de partícipe na consecução das finalidades de interesse público. 


\section{CAPÍTULO I - PRESSUPOSTOS TEÓRICOS.}

"Las categorías políticas [...] son históricamente mudables y las mismas funciones y, con mayor motivo, la estrutura del Estado actual, dependen de la historia. Toda historia es un proceso único, una corriente cuya dirección no admite regresión, y la estructura estatal que pueda existir dentro de una determinada estrutura social general es, esencialmente, inaplicable para cualquier outra situación histórica”. (Herman Heller ${ }^{1}$ )

O presente capítulo tem por objetivo delimitar e explicitar os pressupostos teóricos que servem de base para o desenvolvimento da dissertação e para a análise dos limites e possibilidades do controle judicial dos atos normativos das agências reguladoras. Os pressupostos teóricos são: o princípio da legalidade, a separação de funções do Estado $^{2}$, o surgimento e desenvolvimento das agências reguladoras, e o papel central do Poder Judiciário no atual contexto do Estado.

Como todos estes pressupostos estão interligados por fatores sociais e econômicos, uma alteração, por exemplo, no princípio da legalidade, implica em alteração na separação de funções e na forma de controle judicial da administração. Daí porque optamos por fazer uma análise histórico evolutiva de tais elementos.

A intenção desta exposição é demonstrar que os pressupostos não podem ser analisados de forma estanque, isolada de seu contexto, sob pena de se perder as razões que levaram à existência dos entes reguladores e da forma pela qual o Poder Judiciário exerce o controle sobre eles.

\footnotetext{
${ }^{1}$ Teoría del estado, 1998 [trad. ed. 1934], p. 79.

${ }^{2}$ A despeito de reconhecermos que a doutrina durante décadas criticou o termo separação de poderes, por ser o poder do Estado uno e indivisível, não faremos aqui um inventário da evolução de tal debate, por entendermos desnecessário no atual estágio do debate a respeito da divisão das funções. Com efeito, parece-nos desnecessário repisar a celeuma doutrinária, uma vez que, a nosso ver, a existência dos Poderes Executivo, Legislativo e Judiciário é simplesmente a forma institucional de incorporar a divisão de funções em órgãos distintos e com competências próprias. É dizer: o termo Poder (Executivo, Legislativo e Judiciário) é apenas uma encarnação institucional da função primordial exercida por cada órgão, sem que o fato de a Constituição Federal prever que "[S]ão Poderes da União, independentes e harmônicos entre si, o Legislativo, o Executivo e o Judiciário" (art. $2^{\circ}$ ) represente a dissolução do Poder unitário do Estado, uma vez que, por exemplo, a função jurisdicional do Estado será exercida pelo Poder Judiciário. Assim, para os fins do presente trabalho, os termos função e poder, quando referidos ao Executivo, Legislativo e Judiciário, serão tomados como sinônimos.
} 
Além disso, a separação das funções inicialmente formulada por Montesquieu no século XVII recebeu diversas interpretações e aplicações ao longo da história ${ }^{3}$, de acordo com o contexto político e social na qual foi inserida, de tal forma que interessanos aqui menos o estudo da formulação teórica e mais as formas como esta teoria foi aplicada ao longo do tempo.

A despeito disso, não desconhecemos que tratar da divisão da evolução do Estado em eras ou períodos, com a finalidade de classificar e analisar os diversos estágios de evolução histórica do Estado, seja algo que traga problemas metodológicos. Em primeiro lugar, como todo objeto de estudo, a classificação não pode ser considerada como correta ou incorreta, mas sim útil ou inútil para os fins a que se propõe $e^{4}$ Em segundo lugar, tal divisão em períodos não retrata uma evolução linear e constante do Estado, nem uma ruptura total com o período anterior e o surgimento de movimentos totalmente novos. Tal divisão é feita por motivos didáticos, com a finalidade de destacar os principais aspectos e características do período em estudo.

Para o presente trabalho optamos por fazer uma divisão centrada na figura do Judiciário e seus impactos sobre o controle judicial da administração, ou seja, os períodos que implicaram em formas diferenciadas dessa relação. Assim, entendemos que a principal classificação a ser feita se dá entre o Estado Liberal e o Estado Social, sendo este último dividido em Estado Social de intervenção direta na economia e Estado Social de intervenção subsidiária na economia.

Outro aspecto importante para a delimitação da exposição que faremos se refere ao fato de que o ponto inicial da exposição será a doutrina de separação de poderes formulada por Montesquieu. Apesar de reconhecermos que a noção de separação de funções aparece bem antes de Montesquieu, a análise será feita a partir do tratadista francês por duas razões.

\footnotetext{
${ }^{3}$ De acordo com MARCos PAulo Veríssimo, baseado na obra de Mateucci, "a noção de separação de poderes acabou conduzindo, ao longo do tempo, a concepções jurídicas bastante distintas, não sendo portanto unívoca em sua formulação e em seus significados. Oscilou, genericamente, entre um princípio tendente ao desenvolvimento de mecanismos de controle interno do poder, e outro, bastante distinto, direcionado à elaboração de uma tipologia das funções estatais". (Aproximação sistemática ao controle judicial das agências de regulação econômica no Brasil, p. 13).

${ }^{4}$ A respeito das classificações e seus problemas metodológicos, cf. Agustín Gordillo, Tratado de derecho administrativo, tomo I, $7^{\mathrm{a}}$ ed., 2003, p. I-20 e segs.
} 
Em primeiro lugar, pois a formulação de Montesquieu tomou como base o Estado Inglês do século XVII, já considerado como manifestação do Estado Moderno, assim entendido como o Estado Absoluto que se substitui ao Medievo, e que possui como características principais a concentração do poder absoluto nas mãos do monarca e a separação entre sociedade civil e Estado ${ }^{5}$.

Em segundo lugar, a formulação por ele feita foi a que serviu de inspiração para o Constitucionalismo dos séculos XVIII e XIX nos países adeptos dos sistemas jurídicos ocidentais que serviram de base para o desenvolvimento do presente trabalho, a Civil Law e a Common Law, mais especificamente o direito norte-americano. Nesse passo, enquanto nos países de tradição romanística a leitura feita por Montesquieu levou à vedação ao controle judicial da Administração Pública, com a solidificação da jurisdição administrativa enquanto modo de evitar a intervenção judicial sobre matérias administrativas $^{6}$, nos Estados Unidos o Judiciário sempre teve um papel central na limitação do poder estatal, sendo-lhe permitido o controle dos atos estatais.

Para a finalidade do presente capítulo faremos a análise evolutiva de acordo com a tradição romanística. Não que desconheçamos a influência que o direito norteamericano teve sobre o direito brasileiro ${ }^{7}$ e, notadamente sobre o direito administrativo da primeira metade do Século XX. No entanto, o fato é que a temática do controle judicial da Administração foi tratada pelo direito administrativo brasileiro ${ }^{8}$ muito mais

\footnotetext{
${ }^{5}$ A esse respeito cf. Floriano de AZEVEDo MARQues NeTO, Regulação estatal e interesses públicos, 2002, p. 29 e seguintes.

${ }^{6}$ Dizemos solidificação, pois a jurisdição administrativa francesa já existia antes da Revolução Francesa, justamente com a finalidade de garantir a independência dos administradores e evitar a ingerência dos juízes - à época alocados no Parlamento - sobre os assuntos da Administração. (JACQUES CHEVALLIER, L'état de droit, Revue du Droit Public et de la Science Politique em France et a l'Étranger, 1988, p. 326).

${ }^{7}$ A respeito da influência do direito norte-americano no direito administrativo brasileiro, cf. CAIO TÁcito, Presença norte-americana do direito administrativo brasileiro, Temas de Direito Público, $1^{\circ}$ volume, 1997, p. 13-25; MARIA SYLVIA ZANELA DI PIETRO, O direito administrativo brasileiro sob influência dos sistemas de base romanística e da Common Law, Revista Eletrônica de Direito Administrativo Econômico, $\mathrm{n}^{\mathrm{o}} \quad 8, \quad$ nov./dez. 2006, disponível em http://www.direitodoestado.com/revista/REDAE-8-NOVEMBRO-2006-MARIA\%20SYLVIA.pdf, acesso em 11.12.2010; e MARIA PAULA DALLARI BUCCI, Direito administrativo e políticas públicas, $1^{\text {a }}$ ed., $2^{a}$ tir., 2006, p. 74-79.

${ }^{8} \mathrm{Na}$ realidade, ao dizermos direito administrativo brasileiro referimo-nos à doutrina e à jurisprudência. $\mathrm{O}$ direito administrativo no Brasil, como de resto em praticamente todos os países, sempre foi um direito de baixa densidade normativa, sendo fruto da construção doutrinária e pretoriana, não da legislação, o que o levou a ser muito mais um direito de interpretação temporal e pontual dos institutos, com a constante
} 
com base nos pressupostos originários do direito francês do que do direito norteamericano, o que, a despeito de ser uma inegável contradição ${ }^{9}$, implicou em uma lenta e gradual evolução dos limites da atividade controladora. Assim, o tema do controle judicial dos atos administrativos se liga muito mais à matriz romanística do direito administrativo do que à norte-americana.

\section{I.A. A Ideia de Separação de Funções do Estado em Montesquieu}

A doutrina de Montesquieu a respeito da separação de funções do Estado não foi concebida apenas como ideia teórica, pois tinha como pano de fundo a Constituição Inglesa de $1688^{10}$, originada da Revolução Gloriosa, pela qual a nobreza e a burguesia impuseram uma série de limites à atuação do Rei.

São frutos de tal movimento revolucionário as bases da primeira formulação da legalidade administrativa e da separação de poderes, quais sejam: (i) o império da lei, com a subordinação do monarca às leis editadas pelo parlamento; e (ii) supremacia do parlamento, com a prevalência das leis editadas por tal órgão sobre a common law revelada pelos tribunais ${ }^{11}$.

O cerne da obra de Montesquieu está na garantia das liberdades individuais em face do Estado, o que é feita pelo equilíbrio entre os poderes estatais, através de um sistema de freios, com a finalidade de evitar que um deles se sobressaia sobre demais, o que poderia levar à tirania ${ }^{12}$.

necessidade de atração dos institutos do direito privado e da sua adaptação ao direito administrativo, do que uma construção realizada de acordo com a lei.

9 Dizemos contradição, pois, a despeito do Brasil ter adotado a unidade de jurisdição quando da proclamação da República, com a extinção do Conselho de Estado, os limites do controle judicial sempre foram muito estritos, inclusive no que se refere aos aspectos da legalidade do ato administrativo, conforme será visto ao longo do presente trabalho, especificamente no capítulo III.

${ }^{10}$ A esse respeito, cf. JOSÉ LeVI Mello do AMARAL JÚNIOR, Sobre a organização de poderes em Montesquieu: comentários ao capítulo VI do livro XI de o espírito das leis, Revista dos Tribunais, $\mathrm{n}^{\circ}$ 868, p. 54.

${ }^{11}$ PAULO OTERO, Legalidade de administração pública: o sentido da vinculação administrativa à juridicidade, p. 45-46.

${ }_{12}$ Marcos PaUlo Veríssimo, Aproximação sistemática..., cit., p. 15. 
De acordo com o pensador francês ${ }^{13}$, há três poderes distintos no Estado. $\mathrm{O}$ primeiro é o Legislativo, que tem por incumbência elaborar, corrigir ou revogar as leis. O segundo é o "poder executivo das coisas que dependem direito das gentes", pelo qual se "determina a paz ou a guerra, envia ou recebe embaixadas, estabelece a segurança, evita invasões"14. O terceiro é o "poder executivo das coisas que dependem do direito civil", também chamado de poder executivo do Estado, pelo qual o príncipe ou magistrado "pune os crimes ou julga as questões dos particulares"15.

Após descrever os poderes que compõem o Estado, Montesquieu descreve o funcionamento de cada um deles, afirmando que a divisão dos poderem em órgãos diversos é uma necessidade de garantia da liberdade política, que estaria comprometida se os três poderes fossem reunidos em uma mesma pessoa ou órgão ${ }^{16}$.

No entanto, não basta separar organicamente os poderes do Estado, sendo necessário criar mecanismos de freios entre eles, de tal forma que le pouvoir arrête le pouvoir.

Assim, o Legislativo seria dividido em dois órgãos, sendo um composto por nobres (Câmara Alta) empossados pelo critério hereditário, e outro (Câmara Baixa) composto por representantes eleitos pelo povo. Tais órgãos se limitariam mutuamente, através da faculdade de estatuir, definida por MONTESQUIEU como "o direito de ordenar por si próprio ou de corrigir o que foi ordenado por um outro", e da faculdade de impedir, qual seja o "direito de tornar nula uma resolução tomada por qualquer outro"17.

\footnotetext{
${ }^{13}$ MONTESQuieu, De l'esprit des lois, s.d., p. 142-143.

${ }^{14}$ MontesQuieu, De l'esprit..., cit., p. 143, traduzimos. Como aponta José Levi Mello Do AMARAL JÚNIOR, trata-se de função tipicamente de chefia de Estado, uma vez que o ius gentium é o direito dos povos, ou seja, o direito internacional (Sobre a organização de poderes..., cit., p. 55).

${ }^{15}$ Idem, ibidem.

${ }^{16}$ Conforme afirma Montesquieu em sua célebre passagem: "Lorsque dans la même personne ou dans le même corps de magistrature la puissance législative est réunie à la puissance exécutrice, il n'y a point de liberté, parce qu'on peut craindre que le même monarque ou le même sénat ne fasse de lois tyranniques pour les exécuter tyranniquement. Il n'y a point encore si la puissance de juger n'est pas séparée de la puissance législative et de l'éxecutrice. Si elle étoit jointe à la puissance législative, le pouvoir sur 1 avie et la liberté des citoyens seroit arbitraire; car le joge soroit législateur. Si elle étoit jointe à la puissance exécutrice, le juge pourroit avoir la force d'un oppresseur. Tout seroit perdu si le même homme, ou me même corps des principaux, ou des nobles, ou du peuple, exerçoient ces trois pouvoirs: celui de faire des lois, celui d'exécuter les résolutions publiques, et celui de juger les crimes ou les différends des particuliers". (De l'esprit..., cit., p. 143).

${ }^{17}$ Idem, p. 196.
} 
Nesse passo, a formulação de Montesquieu leva a uma limitação feita pelo próprio Legislativo à sua atividade, uma vez que "Somente pela exata coincidência de vontades entre câmara alta e câmara baixa, é que o poder legislativo estatui. Do contrário, uma câmara neutraliza a outra. Trata-se, portanto, de um bicameralismo igual, em que a câmara alta tem papel moderador, servindo de contrapeso à câmara baixa"18 .

A atividade legislativa também sofre limitação pela faculdade concedida ao Executivo de participar do processo legislativo ao possui a faculdade de impedir a promulgação de uma lei, com a finalidade de evitar que o Legislativo venha a se tornar um poder tirano ${ }^{19}$.

O Judiciário, por sua vez, acaba por ser, nas próprias palavras de Montesquieu, "de algum modo nulo" ${ }^{20}$, uma vez que os juízes são apenas "a boca que pronuncia as palavras da lei, seres inanimados que desta não podem moderar nem a força nem o rigor" ${ }^{21}$. Em outro trecho, afirma o autor francês que os julgamentos deverão ser fixos "a tal ponto que não representem nunca senão um texto fixo da lei. Se representassem uma opinião particular do juiz, viver-se-ia na sociedade sem saber quais os compromissos que nela se contratavam"22.

Assim, da lição de Montesquieu, o juiz somente possui a função de explicitar perante o caso concreto o desígnio já posto na lei, como que numa atividade mecânica de mera subsunção automática. A finalidade precípua de tal ensinamento é a garantia da segurança jurídica, evitando-se qualquer interpretação fora do texto seco da lei.

No entanto, a despeito de tais lições terem influenciado tanto os constituintes da Europa continental, quanto os norte-americanos, a recepção e o desenvolvimento de tais lições de Montesquieu se deram de maneira diversa em tais sistemas jurídicos, o que trouxe impacto para o direito brasileiro.

\footnotetext{
18 José LeVi Mello do AMARAL JÚNIOR, Sobre a organização de poderes..., cit., p. 61.

${ }^{19}$ MONTESQuiEu, De l'esprit..., cit., p. 150.

${ }^{20}$ Idem, p. 148.

${ }^{21}$ Idem, p. 151.

${ }^{22}$ Idem, p. 193.
} 


\section{I.B - Análise Evolutiva da Separação de Funções e da Legalidade}

\section{I.B.1 - O Estado Liberal de Direito}

A análise começa com o surgimento do Estado de Direito, por ser o período considerado como marco histórico do surgimento do direito administrativo enquanto ciência dogmática, em virtude da ascensão do princípio da legalidade e da tripartição de funções do Estado, marcos do constitucionalismo moderno ${ }^{23}$.

Antes dessa fase ${ }^{24}$, no entanto, é possível identificar manifestações da função administrativa, ainda que não sistematizada e organizada do modo como a conhecemos hoje, uma vez que, como bem anota Oswaldo ARANHA BANDEIRA DE MELlo, sempre houve normas que regulam a atividade estatal, sua organização e a criação de utilidades públicas para a sociedade ${ }^{25}$. Nesse passo, válidas as palavras de JEAN-LOUIS MESTRE ${ }^{26}$, que, após fazer importante incursão na doutrina administrativista francesa a respeito da data de criação do direito administrativo, afirma que:

Incontestavelmente, sob o Antigo Regime, é elaborado um verdadeiro corpo de regras relativas à administração. Decerto, a autonomia deste corpo de regras não foi proclamado de modo absolutamente formal. Decerto, estas regras provinham de origens diversas e não estavam ligadas entre si de modo sistemático. Mas elas

\footnotetext{
${ }^{23}$ A esse respeito ensina MARIA SYlvia ZANELla DI PIETRO: "O direito administrativo nasceu junto com o constitucionalismo. O princípio da legalidade, junto com o princípio da separação dos poderes, o princípio da isonomia, o princípio da justicialidade (que exige o controle judicial dos atos estatais)". Da constitucionalização do direito administrativo: reflexos sobre o princípio da legalidade e a discricionariedade administrativa, in Maria Sylvia Zanella di Pietro; Carlos Vinicius Alves Ribeiro, Supremacia do interesse público e outros temas relevantes do direito administrativo, São Paulo: Atlas, 2010, p. 175-196, especificamente, p. 179.Na mesma linha, cf. ODETE MEDAUAR, O direito administrativo em evolução, $2^{\mathrm{a}}$ ed., 2003, p. 23-26; OsWALDO ARANHA BANDEIRA DE MELLO, Princípios gerais de direito administrativo, vol. I, $2^{\mathrm{a}}$ ed.,p. 52.

${ }^{24}$ A respeito do direito administrativo antes da era do constitucionalismo, cf. MARIA SYLVIA ZANELLA DI PIETRO, 500 anos de direito administrativo brasileiro, Revista Eletrônica de Direito do Estado, Salvador: Instituto de Direito Público da Bahia, $\mathrm{n}^{\circ}$ 5, janeiro/fevereiro/março de 2006, disponível em www.direitodoestado.com.br, acesso em 15.06.2011. Para uma análise do instituto da concessão desde o tempo de Roma e Grécia até o Antigo Regime, cf. FloriANO DE AZEVEDO MARQUES NETO, A concessão como instituto do direito administrativo, 2013, p. 46-64.

${ }^{25}$ Princípios gerais de direito administrativo, vol. I, $2^{\mathrm{a}}$ ed., 1969, p. 51. Na mesma linha, cf. SABINO ÁlVAREZ-GEDín, Tratado general de derecho administrativo, Tomo I, p. 138-140.

${ }^{26}$ Introduction historique au droit administratif français, 1985, p. 13 (tradizimos). No original: "Incontestablement, sous l'Ancient Régime, s'est élaboré un véritable corps de règles relatives à l'administration. Certes, l'autonomie de ce corps de régles n'a pas été proclamée de façon absolument formelle. Certes, ces règles provenaient d'origines diverses, et n'étaient pas reliées entre elles de façon systhématique. Mais, elles dotaient l'administration d' un régime juridique d'ensemble, qui établissait une sorte d'équilibre entre les exigences de l'intérêt général et le respect des droit des administrés".
} 
dotaram a administração de um regime jurídico de conjunto, que estabeleceu uma espécie de equilíbrio entre as exigências de interesse geral e o respeito aos direitos dos administrados.

Diante disso, conclui o autor ser possível escrever uma história do direito administrativo francês que "transponha a cesura da Revolução de 1789"27.

Dessa forma, para os fins do presente trabalho, interessa-nos a evolução do direito administrativo após as Revoluções liberais dos Séculos XVIII e XIX, por ser o período de consolidação de tal disciplina tal como é entendida hoje. O Estado de Direito é fruto de tais Revoluções, que tiveram como objetivo principal romper com as estruturas e instituições do Absolutismo monárquico, notadamente, com o poder ilimitado do governante e de dotar o cidadão de direitos em face do Estado ${ }^{28}$.

Trata-se de um processo de substituição do Rei pela Nação, como detentora do poder estatal, bem como de repartir as funções do Estado entre órgãos independentes e de mútua fiscalização, com a finalidade de evitar que um mesmo órgão exerça as funções estatais até então identificadas, a legislação, a administração e a jurisdição. $O$ poder estatal continua uno e indivisível, assim como no surgimento do Estado Moderno $^{29}$, com o Absolutismo monárquico, mas as funções desempenhadas pelo Estado como manifestação do seu poder são cindidas e a legitimação para a atuação estatal deixa de estar enfeixada na figura do monarca, passando a recair sobre a Nação.

Tem-se a dessacralização do poder, para usar expressão de JACQUES CHEVAllier $^{30}$, uma vez que o Poder passa a ser detido não mais por critérios sobrenaturais, por mandamento da divindade, mas sim pelo exercício do Poder da

\footnotetext{
${ }^{27}$ Introduction historique au droit administratif français, p. 14.

${ }^{28}$ De acordo com Norberto BOBBIO, "O pressuposto filosófico do Estado liberal, entendido como Estado limitado em contraposição ao Estado absoluto, é a doutrina dos direitos do homem elaborada pela escola do direito natural (ou jusnaturalismo): doutrina segundo a qual o homem, todos os homens, indiscriminadamente, têm por natureza e, portanto, independentemente de sua própria vontade, e menos ainda da vontade de alguns poucos ou de apenas um, certos direitos fundamentais, como direito à vida, à liberdade, à segurança, à felicidade - direitos esses que o Estado, ou mais concretamente aqueles que num determinado momento histórico detêm o poder legítimo de exercer a força para obter a obediência a seus comandos devem respeitar, e portanto não invadir, e ao mesmo tempo proteger contra possível invasão por parte dos outros". (Liberalismo e democracia, 2000, p. 11).

${ }^{29}$ Nesse sentido cf. Floriano de Azevedo Marques Neto, Regulação estatal e interesses públicos, 2002, p. 29-41.

${ }^{30}$ La dimension symbolique du principe de légalité, Revue du Droit Public et de la Science Politique en France et à l'Étranger, nº 6, 1990, p. 1663.
} 
Nação e em nome desta. Afirma GARCIA DE ENTERRÍA, que “a Revolução 'desencanta' o poder, o reduz a um mecanismo humano, comum, ordinário, racional"31. A derrocada da forma estamental, histórica e pessoal do poder, característica típica do Antigo Regime, implica, a um só tempo, na impossibilidade de exercício do Poder em nome próprio, uma vez que este deve ser feito em nome da Nação, e na delegação do seu exercício aos representantes do povo ${ }^{32}$, alocados, à época, no Parlamento ${ }^{33}$. Com isso começamos a delinear uma das principais características deste período: o protagonismo do legislativo frente às demais funções do Estado.

Tal protagonismo do legislativo se deve a uma construção que está na base do Estado de Direito, estruturada sobre (i) a ordem jurídica estática, vinculada a outras normas superiores hierarquicamente, com a possibilidade de controle judicial desta relação, (ii) a submissão do Estado ao Direito, o que implica na criação de mecanismos de controle da ação estatal e (iii) um conteúdo de garantia dos direitos dos cidadãos em face do Estado ${ }^{34}$.

O controle da atuação estatal se dá pela adoção nos sistemas jurídicos do princípio da justicialidade, pelo qual as questões que envolvam o Estado devem ser passíveis de revisão pelo Poder Judiciário, através da aferição da legalidade da atuação, o que implica "na conformação judicial de toda a vida do Estado" ${ }^{3}$.

De acordo com tal princípio, então, é necessário que haja um procedimento litigioso, que seja processado perante a jurisdição, para possibilitar o controle da atuação estatal, sob o prisma da legalidade. Conforme MANOEL GonÇALVES FERREIRA

\footnotetext{
${ }^{31}$ La lengua de los derechos. La formación del derecho publico europeo tras la revolución francesa, $3^{\mathrm{a}}$ ed., 2009, p. 121.

32 EduARdo Garcia de ENTERria, La lengua..., cit., p. 122-123.

${ }^{33}$ Tal marca das Revoluções Burguesas é bem demonstrada por três dispositivos normativos da época. Por meio do art. $3^{\circ}$ da Declaração dos Direitos do Homem e do Cidadão, de 1789, "O princípio de toda a soberania reside, essencialmente, na nação. Nenhum corpo, nenhum indivíduo pode exercer autoridade que dela não emane expressamente". Posteriormente, em 1791, quando da promulgação da Constituição, o art. $1^{\circ}$, do Título III (Dos Poderes Públicos), determinava que "A Soberania é una, indivisível, inalienável e imprescritível. Pertence à Nação; nenhuma parte do Povo, nem nenhum indivíduo pode atribuir-se seu exercício". Por sua, vez, o artigo $2^{\circ}$ do mesmo Título da Constituição afirmava que "A Nação, de quem unicamente emanam todos os Poderes, somente pode ser exercida por delegação. A Constituição francesa é representativa: os representantes são o corpo legilativo e o rei”.

${ }^{34}$ JaCQues Chevallier, L'état de droit, Revue du Droit Public et de la Science Politique en France et à l'Étranger, no 2, 1988, p. 317.

${ }^{35}$ Carl Schimtt, Teoría de la constitución, 1966, p. 154, apud MANOEl GonÇAlves FERREIRA FILHO, Estado de direito e constituição, $4^{\mathrm{a}}$ ed., 2007, p. 32.
} 
FILHO, "O campo de preferência da justicialidade é a aferição da legalidade. Toda questão de legalidade deve ser resolvida segundo um procedimento litigioso e perante um juiz. Isto é, alguém que há de dizer o Direito. A função do magistrado que julga é exatamente essa: dizer o Direito" ${ }^{36}$.

No entanto, a despeito de ganhar importância como instância de aferição da legalidade da atuação do Executivo, o Judiciário é limitado em demasia pela concepção de legalidade que se tinha em tal época.

Com efeito, a burguesia que ascendia ao Poder necessitava, para se consolidar, de um sistema que lhe assegurasse a manutenção das premissas do sistema econômico, notadamente do direito de propriedade ${ }^{37}$, eliminando o caráter de insegurança gerado pela manutenção do poder normativo apenas nas mãos do monarca, o que seria feito através de um veículo de introdução de normas que represente a vontade da população, posto por meio de um procedimento previamente estabelecido por norma de hierarquia superior.

Impulsionada pelo racionalismo filosófico dominante nos Séculos XVIII e XIX, tornava-se necessário afastar, além dos dogmas sobrenaturais do poder real, o aspecto metajurídico do jusnaturalismo ${ }^{38}$, positivando os valores difundidos por tal doutrina, como forma de estabelecer segurança jurídica nas relações entre os indivíduos e o Estado, o que se deu, num primeiro momento, com o art. $2^{\circ}$ da Declaração dos

\footnotetext{
${ }^{36}$ Estado de direito..., cit., p. 33.

${ }^{37}$ A respeito da importância capital do direito de propriedade para o Direito burguês dos Séculos XVIII e XIX, cf. MARCUS FARO DE CASTRO, Formas jurídicas e mudança social: interações entre o direito, a filosofia, a política e a economia, 2012, p. 130-133.

${ }^{38}$ Conforme ensina MARCUS FARO DE CASTRO, ao tratar das diversas formas de positivismo jurídico surgidas no Século XVIII e no denominador comum de todas elas: "Quanto aos positivismos jurídicos, torna-se claro que a resultam de uma rejeição da exigência de fazer as 'formas' da doutrina jurídica repousarem sobre fundamentos metafísicos. De fato, no direito, o abandono da metafísica setecentista significaria deixar de levar em conta as elucubrações filosóficas dos jusnaturalistas: os discursos elaborados por meio da dialética especulativa sobre o que eram o Estado de Natureza, o Contrato Social, a Sociedade Civil, as considerações ou quase devaneios da antropologia filosófica, sobre os 'princípios' da 'razão natural', os deísmos e assim por diante. Dessa nova orientação nascem diversas espécies de 'positivismo jurídico' (textualista, utilitarista, historicista etc., conforme se verá a seguir). Nesse sentido, o denominador comum de todas essas abordagens caracterizáveis como positivismo jurídico será o ser pressuposto da exclusão metodológica da possibilidade de recorrer à especulação moral como meio de elaboração das 'formas' jurídicas. Proibir a livre especulação moral para o jurista ocupado em sua tarefa de determinar o sentido inteligível dos referenciais normativos constitutivos do direito - aí estava a característica básica dos positivismos jurídicos que surgiriam a partir de finais do século XVIII".
} (Formas jurídicas..., cit., p. 142). 
Direito do Homem e do Cidadão de 1789, ao determinar que "A finalidade de toda associação política é a conservação dos direitos naturais e imprescritíveis do homem. Esses direitos são a liberdade, a propriedade, a segurança e a resistência à opressão".

A lei surge, então, como o instrumento próprio para servir aos anseios da burguesia, por ser um veículo normativo posto pelos representantes do povo, alocados no Legislativo, onde a burguesia possuía representatividade, e produzido num ambiente controlado, ou seja, num sistema hierarquizado, pelo qual a norma inferior, somente é válida se obedecer aos comandos superiores.

Nessa fase de início e afirmação do Estado de Direito, a lei, entendida como "l'expression de la volonté général" ${ }^{39}$, e o sistema jurídico por ela criado são dotados de características $^{40}$ que lhes atribuem aspectos míticos da perfeição e da completude, vinculando diretamente o administrador e o Juiz, que somente podem agir de acordo e nos estritos limites dos comandos normativos. A análise do juiz é meramente gramatical, com o predomínio do brocardo in claris cessat interpretatio.

A primeira característica de que é impregnada a lei pelos juristas pósrevolucionários, que a transformam em um mito incontestável, é a autoridade, em virtude da sua emanação pelo Estado, o que implica num privilégio de transcendência: por ser a depositária do senso da sociedade e única detentora da palavra legítima, ela possui uma identidade social o que lhe concede uma identidade indiscutível ${ }^{41}$.

A segunda característica apontada é a racionalidade do texto legal, que decorre, de um lado, do seu método de elaboração, fruto de um processo no qual os indivíduos são representados pelos parlamentares, de tal forma que "a lei se torna uma palavra na qual qualquer um pode se reconhecer, já que é presente, ao menos indiretamente ou de

\footnotetext{
${ }^{39}$ Artigo $6^{\circ}$ da Declaração dos Direitos do Homem e do Cidadão de 1789.

${ }^{40}$ JACQUES CHEVALLIER, La dimension symbolique..., cit., p. 1654-1661.

${ }^{41}$ JACQUES CHEVALLIER, La dimension symbolique..., cit., p. 1654. Anota ainda o autor, que tal dimensão transcendental, nas sociedades primitiva e medieval, decorria da vontade dos deuses ou de Deus, ao passo que, após a teoria da soberania, passou a ser identificada com a figura do Estado. (op. cit, p. 1654-1655).
} 
maneira mediata, na sua elaboração" ${ }^{42}$. Trata-se da racionalidade em virtude dos postulados majoritário e representativo ${ }^{43}$.

De outro lado, a racionalidade decorre de suas características formais ${ }^{44}$. De início, há a lógica, pela qual a lei é concebida com um ato coerente, decorrente de proposições normativas articuladas, o que evita a existência de contradições. Além dela, a generalidade é outra característica da lei, de tal forma que as regras sociais são colocadas de modo mais e mais abstrato, com a finalidade de evitar particularismos, de modo que, diante da lei, todos são iguais em virtude de sua imparcialidade e neutralidade. Por fim, a lei é estável, o que garante aos cidadãos a possibilidade de prever, antes da prática do ato, quais as suas consequências e quais as regras aplicáveis.

A terceira característica é a justiça que cerca a lei posta. Originalmente pensada pelos revolucionários como modo de conter o poder do Estado, a lei passa a ser método de garantir a igualdade entre os indivíduos, o que é considerado como manifestação de justiça. Para tanto, a lei é dotada de características de generalidade e abstração, o que concede a possibilidade de ser aplicada de forma idêntica aos indivíduos ${ }^{45}$.

A quarta característica liga-se à ordem estabelecida pela lei, tanto no que se refere à normatividade quanto à sistematicidade. Assim, a característica da ordem significa tanto a ordem posta pela lei, o seu mandamento para os indivíduos e o Estado, quanto a noção de ordem jurídica, ou seja, de um conjunto coerente de leis que formam um todo unitário de elementos que se ligam por relações lógicas.

\footnotetext{
42 JACQUES CHEVALliER, La dimension symbolique...., cit., p. 1656, traduzimos. No original: "la Loi deviant une parole dans lequelle chacun peut se reconnaître puisqu'il est présent, aumoins indirectement ou de manière médiate, das son élaboration".

${ }^{43}$ Conforme Manuel GarcíA-Pelayo, "La discusión parlamentaria es el procedimiento adecuado para descobrir la racionalidad objetivaen su dimensión normativa, del mismo modo que lo es la libre concurrencia en el mercado para actualizar una racionalidad económica objetiva. Partiendo de estos supuestos, la ley, genérica y abstracta, como lo es la razón, crea ella misma uma racionalidad objetiva, un orden racional al que deben adaptarse y al que pueden reducirse las conductas y los acontecimentos". (Las transformaciones del estado contemporâneo, 1977, p. 62).

${ }^{44} \mathrm{~A}$ respeito das características formais da lei, cf. JACQUES CHEVALLIER, La dimension symbolique...., cit., p. 1657-1658.

${ }^{45}$ Conforme ensina Manoel Gonçalves Ferreira Filho, "Enfim, somente é lei a regra geral. Para a norma ser qualificada como lei, é essencial que ela disponha de in abstracto para reger todos os casos da mesma natureza, concebida sem acepção de pessoas, destinada, pois, a se aplicar a todos os indivíduos que se achem nas mesmas condições que preveja. Assim, ao limitar a liberdade em vista das exigências sociais, a lei necessariamente irá impor em todos os casos os mesmos limites para todos os homens, e nisto já está uma garantia de que ela servirá à justiça. (...) Da generalidade da lei, pois, deflui a igualdade. Sendo regra geral, a lei é regra igual para todos". (Estado de direito..., cit., p. 21).
} 
Por fim, a quinta característica é a infalibilidade da lei, que "é o corolário lógico dos atributos precedentes: encarnação da Verdade, da Razão, da Justiça, a Lei é percebida como um ato incontestável e no qual o fundamento não será posto em dúvida" ${ }^{\prime 4}$.

Cria-se, então, um sistema jurídico (i) nitidamente preocupado com o controle do poder, notadamente do Poder Executivo, (ii) que tem o seu centro de ação focado na lei, como instrumento de limitação do poder, através da submissão de todos à ela, e (iii) que busca a sua legitimidade no próprio processo de formação das leis, entendido como um processo democrático no qual há a manifestação da Nação, ainda que indiretamente por meio de representantes o povo.

Se o Legislativo era o locus ideal para o debate político, sendo o veículo da decisão por ele tomada (a lei) um ato racional e infalível, o Judiciário dessa época seria absolutamente imune às pressões políticas, cabendo-lhe uma função unicamente técnica: a de aplicar a lei ao caso concreto, sem discussão a respeito do conteúdo da norma posta, uma vez que tal discussão seria travada no âmbito apenas da política, o que era feito pelo Parlamento. Instaurava-se o processo de separação entre Política e Direito, com a finalidade de imunizar o Juiz das pressões e dos debates políticos, fazendo dele um aplicador mecânico da lei posta pelo Parlamento, pela Nação, através do método da subsunção ${ }^{47}$. Afinal, "a independência do Judiciário tem por preço sua dependência à lei" ${ }^{48}$.

\footnotetext{
${ }^{46}$ JACQUES CHEVALLIER, La dimension symbolique....., cit., p. 1660.

${ }^{47}$ Conforme ensina TÉRCIO SAMPAIO FERRAZ JÚNIOR, "A neutralização foi acompanhada de uma desvinculação progressiva que iria sofrer o direito de suas bases sociais. Inicialmente, ela significaria neutralização política, para depois exigir distanciamento ético. Assim, com a canalização de todas as projeções normativas com pretensão de validade para o endereço político do Legislativo e o consequente tratamento oportunístico dos valores máximos (cresce a força e a importância do positivismo jurídico), a neutralização do Judiciário se apoiará na centralização organizada da legislação (só a lei, votada e aprovada pelos representantes do povo, obriga) e reforçará lugar privilegiado da lei como fonte do direito. Este reforço ocorre não só pela exaltação da do princípio da legalidade e a consequente proibição da decisão contra legem, mas também pelo ato jurisdicional como um processo de subsunção do fato à norma. Ao sublinhar-se a subsunção como o método de aplicação do direito, neutraliza-se para o juiz o jogo dos interesses concretos na formação legislativa do direito (se esses interesses serão atendidos ou decepcionados não é problema do juiz, que apenas aplica a lei). Por conseguinte, sua atividade jurisdicional guiada superiormente pela lei e pela constituição não se vincula a nenhum direito sagrado ou natural nem exige um conteúdo ético ainda que teleologicamente fundado. Acima de tudo, o importante é que a lei seja cumprida". (O judiciário frente à divisão dos poderes: um princípio em decadência?, Revista Trimestral de Direito Público, no 9, p. 41-42).

${ }^{48}$ Celso Fernandes CAMPILONGO, Política, sistema jurídico e decisão judicial, $2^{a}$ ed., 2012, p. 35.
} 
Tal construção limitadora da função do juiz foi elaborada com um triplo objetivo.

Em primeiro plano, evitar que a nobreza derrotada pelas Revoluções liberais obstruísse as reformas provocadas pela burguesia, uma vez que a classe dos magistrados era formada essencialmente pelos nobres. Afinal, "a recepção de Montesquieu na França pós-revolucionária foi caucionada por um contexto que via no poder dos juízes (em larga medida vinculados ao Ancient Régime) o inimigo a ser combatido"49. Conforme anota LÉON DUGUIT ${ }^{50}$, durante o Antigo Regime vigorava a máxima de que “Toda justiça emana do Rei”, sendo que esta não contestada pelos revolucionários franceses que a adotam como verdadeira, de modo que o Judiciário não é visto como função autônoma, mas como função subordinada ao Rei. Além disso, aponta o autor francês, através da detida análise dos discursos da Assembleia Constituinte de 1789, que o que se temia era o abuso da função judicial com a sua intervenção sobre o exercício da Administração Pública. Neste cenário político, por óbvio, não há espaço para a estipulação do controle judicial da atividade administrativa, uma vez que os juízes são vistos como inimigos da revolução, adotando a Constituição francesa uma configuração que, na visão de ROGER BONNARD ${ }^{51}$, implicou numa visão distorcida do pensamento de Montesquieu, com uma ideia de separação de poderes por meio da abstenção de atuação de um sobre o outro.

Em segundo lugar, imunizar o Judiciário das pressões políticas do soberano, permitindo que a decisão judicial seja tomada não de acordo com os anseios deste, mas conforme critérios previamente estipulados na lei, o que dará a legitimidade ao ato emanado pelo Estado-Juiz ${ }^{52}$.

\footnotetext{
${ }^{49}$ Celso Fernandes Campilongo, Política ..., cit., p. 30.

${ }^{50}$ La separación de poderes y la asamblea nacional de 1789, 1996, p. 118-119.

51 Le contrôle jurisdictionnel de l'administration, 1934 [reimp. 2006], p. 99. A respeito de uma interessante leitura das razões da vedação à análise judicial dos atos administrativos em tal período, conferir ALBERT VENN DICEY, Introduction to the study of the law of the constitution, $9^{\mathrm{a}}$ ed., 1956, p. 338-343.

${ }^{52}$ A esse respeito, cf. Celso Fernandes Campilongo, Política ..., cit., p. 32.
} 
Em terceiro plano, a decisão judicial que simplesmente reproduz mecanicamente a Lei possui alto grau de previsibilidade e segurança jurídica, o que atendia aos anseios daquela sociedade.

Nas palavras de PAUlo Otero, que trata do sistema jurídico Inglês do século XVII, mas que veio a ser a base da separação de funções do Estado e da legalidade espraiadas pelo Estado Liberal, "Fazendo do monarca e dos tribunais simples órgãos de aplicação da lei, o parlamento britânico consolida-se como instituição política suprema, traduzindo-se a lei formal na fonte primeira do ordenamento jurídico: o Direito de origem parlamentar deixa de conhecer quaisquer limites e torna-se o fundamento de actuação de todo o poder",53.

Como resultado de tal fase de afirmação do Estado de Direito, em contraposição ao regime absolutista anterior, tem-se, para o que interesse ao presente trabalho: (i) a exaltação do legislador sobre o administrador e o juiz, que tinham a mera função de cumpridores das determinações legais; (ii) a lei como produto racional e perfeito do processo legislativo, de seguimento obrigatório pelos administradores e juízes, que não podiam fugir ao cumprimento mecânico e automático das disposições legais ${ }^{54}$.

\footnotetext{
${ }^{53}$ Legalidade de administração pública..., cit., p. 46. Tal contexto foi bem sintetizado por CELSO FERNANDES CAMPILONGO, ao afirmar: "No modelo de Estado liberal, ao Legislativo era atribuída a verdadeira função de governo. O Executivo e o Judiciário eram poderes coadjuvantes do protagonismo político do Legislativo. No processo de superação do antigo regime absolutista, a tese da divisão de poderes, com o destaque conferido ao Legislativo, surge como fórmula capaz de atingir os seguintes objetivos: deslocar o centro de decisão política para uma arena na qual a burguesia tinha assento (o Parlamento); impor limites à atuação do monarca, isto é, controlar o Executivo; dotar o Judiciário de uma posição institucional protegida das interferências do sistema político e orientada por critérios transparentes e previamente conhecidos (certeza jurídica, previsibilidade e garantia das expectativas)". (Política..., cit., p. 31-32).

${ }^{54}$ Demonstrando visão pessimista e crítica a respeito de tais características da separação de funções e da legalidade em tal período, ANTOINE DE SAINT GIRONS escreveu: "Les ideés sur la souveraineté du peuple, font traiter le pouvoir exécutif en ennemi. Le roi garde quelques honneures et vains titres: il n'a plus de puissance. Le pouvoir législatif est omnipotent; les tribunaux affaiblis et availis, rendent la justice précaire et vénale. Ni liberté politique, ni liberté civile: voilá le triste résultat de tant d'efforts et de sacrifices". (Essai sur la séparation des pouvoirs dans l'orde politique, administratif et judiciaire, 1881, p. 134).
} 


\section{I.B.2 - O Estado Social de Direito de Intervenção na Economia ${ }^{55}$}

No entanto, estes pressupostos teórico-políticos de predomínio do Legislativo e de seu produto, a lei, sobre as demais funções do Estado não foram capazes de se manterem ao longo do Século XX. O advento da sociedade industrializada trouxe consigo uma série de desigualdades sociais que não poderiam ser solucionadas pelo modelo liberal de Estado de Direito, que tinha como objetivo central a proteção da propriedade e da liberdade, a não interferência na esfera do indivíduo.

O Estado, para manter a sua legitimidade frente à sociedade, necessitou de mudanças na sua forma de atuar. Deixou de ser o garante da ordem econômica e social e passou a ser o grande interventor tanto na Economia quanto na sociedade para manter as condições de vida mínimas da população ${ }^{56}$.

Tais mudanças na missão do Estado, que se transformou “de 'guarda nocturno' em suprema entidade repartidora de rendimentos e prestadora de bens e serviços" ${ }^{\text {57, }}$ implicou na alteração da forma como este se relaciona com a sociedade. No Estado Liberal havia uma separação total entre sociedade e Estado, sendo este concebido como organização racional, de estrutura hierárquica, com a racionalidade marcada pela edição de leis abstratas e pela divisão de poderes como forma de garantir a liberdade e a propriedade, ao passo que aquela era tomada como um outro sistema independente, dotado de racionalidade movida pelas leis econômicas e de competição, que acabavam

\footnotetext{
${ }^{55}$ Conforme bem pontua EROS ROBERTO GRAU, a intervenção estatal na economia poderá se dar de três formas: (i) por absorção ou participação, (ii) por direção e (iii) por indução. No primeiro caso, o Estado atua no domínio econômico, ao atuar como agente econômico, o que poderá ser feito por absorção de atividades, com a constituição de monopólios em seu favor, impedindo que os privados prestem tal atividade, ou por participação, hipótese em que atua em regime de competição com os particulares. Nos segundo e terceiros casos, o Estado atua sobre o domínio econômico por direção, quando estipula regras cogentes a serem seguidas pelos agentes econômicos, ou por indução, quando se utiliza dos instrumentos econômicos para induzir os privados a tomar determinadas atitudes no âmbito econômico sem, contudo, se valer de instrumentos de imposição de obrigações, o que se dará, por exemplo, através da concessão de benefícios fiscais para aqueles que agirem de determinada forma. (A ordem econômica na constituição de 1988, $12^{\mathrm{a}}$ ed., 2007, p. 148-151).

${ }^{56}$ Conforme MANUEl GARCíA-PElAyo, "si el Estado quería subsistir había de disponerse a controlar permanentemente los aspectos económicos, sociales y culturales de la sociedade. Y si el Estado democrático liberal de Derecho quería continuar tendo vigencia había que adaptar sus valores a las nuevas exigencias y añadir a sus objetivos los de la regulación permanente del sistema social. (Las transformaciones del estado moderno, 1977, p. 24).

57 JOSÉ MANUEL SÉRVULO CORREIA, Legalidade e autonomia contratual nos contratos administrativos, 1987, p. 44.
} 
com a subordinação de uma classe pela outra ${ }^{58}$. No Estado Social, por outro lado, tem-se uma lógica distinta. Em virtude da necessidade da presença do Estado para estruturar as ordens social e econômica, cujos mecanismos de auto-regulação levam à irracionalidade $^{59}$, a sociedade passa a querer influir nos rumos da política estatal, o que leva à uma dupla coerção entre o Estado e a sociedade.

O Estado passa a ser obrigado a atuar de forma a mitigar as desigualdades sociais, o que implica na promoção de ações para fornecer aos menos favorecidos as prestações de serviços que o mercado não é capaz de oferecer. Inicialmente, nas últimas décadas do século XIX, essas prestações eram setorizadas, não tendo por objeto a real mudança social da população, mas apenas remediar e corrigir as péssimas condições de vida da população menos amparada materialmente. Com o passar das décadas, tem-se uma atuação cada vez mais ampla, de tal forma que a política setorial passa a ser generalizada, abrangendo setores não apenas ligados às desigualdades sociais, mas também conectados à cultura, lazer, educação, defesa do meio-ambiente, promoção do desenvolvimento de regiões atrasadas etc ${ }^{60}$. Assim, a política que era setorial passa a ser universal, como forma do Estado controlá-las de modo organizado e sistematizado ${ }^{61}$, de modo que "a Administração Pública tende a ocupar-se praticamente de tudo, desenvolvendo a sua atividade em todos os sectores da vida económica e social”,62.

O Estado deixa apenas de se preocupar em garantir as condições sociais e passa a se voltar a evitar situações futuras de risco sobre as políticas realizadas, com a finalidade de evitar uma maior degradação da sociedade. Trata-se da alteração apontada por PAUlo OTERO ${ }^{63}$, de um Estado-Zorro, protetor dos "fracos, das minorias, dos deserdados, das vítimas de um desenvolvimento descontrolado, prestando serviços e distribuindo compensações e rendimento sociais", para um Estado-segurança ou

\footnotetext{
${ }^{58}$ MANUEL GARCÍA-PELAYO, Las transformaciones..., cit., p. 21-22.

${ }^{59}$ Idem, p. 22-23.

${ }^{60}$ Idem, p. 18-19.

${ }^{61}$ Conforme ensina MANOel GonÇAlves Ferreira FILHO: "Quando, por influência dos socialistas e cristãos-sociais, se veio a entender o Estado como a providência dos malsucedidos, começou-se a abandonar a fórmula setecentista de Estado de Direito. O Estado-Providência, preocupado em dar a todos condições adequadas de vida, intervém no domínio econômico e social. Tendo, por isso, a reduzir a autonomia individual e, tomado de racionalismo (no que é digno herdeiro do pensamento setecentista), quer ordenar os mais diferentes setores da vida social". (Estado de direito..., cit., p. 42).

${ }^{62}$ MARIA JOÃO ESTORNINHO, A fuga para o direito privado: contributo para o estudo da actividade de direito privado da Administração Pública, 2ª reimp., 2009, p. 37.

${ }^{63}$ Legalidade..., cit., p. 157.
} 
Estado-preventivo, "preocupado em dominar potenciais situações futuras de risco sobre a segurança do grau de vantagens prestacionais ou planeadas". Conforme o autor português ${ }^{64}$ :

\begin{abstract}
Há aqui uma ampliação do horizonte material e temporal de actuação do Estado sobre a sociedade: além de visar a transformação da sociedade existente num determinado momento histórico, aumentando o nível presente de qualidade de vida ou de bem-estar da colectividade, o Estado desenvolve também uma função prospectiva, antecipando e prevenindo riscos e defendendo interesses das gerações futuras no contexto de uma sociedade globalizada, de alto risco em termos científicos e tecnológicos e, por último, pulverizada de interesses contraditórios, conflituantes e quase sempre inconciliáveis nas suas permanentes reivindicações.
\end{abstract}

No campo econômico, a atuação estatal passa a ser marcante. Se o Estado Liberal tinha como objetivo no campo econômico o laissez faire, que, na arguta lição de FÁBIO Konder COMPARATO ${ }^{65}$, se tornava o laissez ne pas faire, o Estado social pretende a intervenção na economia com a finalidade de corrigir as falhas ocorridas no mercado, diminuir desigualdades regionais, investir em infraestruturas em setores que não interessavam à iniciativa privada, além de mitigar as desigualdades entre empresas e setores econômicos. Na lição de AleXAndre SANTOS DE ARAgÃo, a intervenção estatal na economia "devia-se a razões de equidade social e a imperativos do próprio sistema econômico, tais como a criação de infra-estruturas vultosas não-lucrativas ou de lucratividade diferida, a necessidade de evitar a monopolização de setores da economia e o fomento de regiões menos desenvolvidas" ${ }^{66}$.

Conforme Odete Medauar, "Se no Estado do século XIX, como se expôs, se encontram algumas medidas estatais nesse campo, passou a vigorar a política estatal de permanente direção do sistema econômico, embora se mantenha o princípio da iniciativa privada e do mercado, formando no conjunto o que os alemães denominaram de economia social de mercado" ${ }^{67}$. De acordo com ERNST FORSTHOFF ${ }^{68}$, a partir do momento em que o Estado percebe a ordem social não como um dado posto pela livre iniciativa dos cidadãos, mas como algo objeto de conformação, a atuação estatal deve

\footnotetext{
${ }^{64}$ Idem, ibidem.

${ }^{65} \mathrm{O}$ indispensável direito econômico, Revista dos Tribunais, ${ }^{\circ}$ 923, set./2012, p. 40.

${ }^{66} \mathrm{O}$ poder normativo das agências reguladoras independentes e o estado democrático de direito, Revista de Informação Legislativa, $\mathrm{n}^{\circ}$ 148, p. 277.

${ }^{67} \mathrm{O}$ direito administrativo em evolução, $2^{\mathrm{a}}$ ed., 2003, p. 88.

${ }^{68}$ Tratado de derecho administrativo, 1958, p. 109.
} 
ser voltada à melhora das condições de vida dos cidadãos, uma vez que a ordem social movida apelas pelos privados não pode ser considerada fundamentalmente justa.

A sociedade, por sua vez, passa a coagir o Estado a atuar com a finalidade de criar de condições de vida dignas aos menos favorecidos, além de intervir de modo a racionalizar setores da vida social que haviam perdido a capacidade de autorregulação. Assim, todas as camadas sociais passam a exigir do Estado que aja de modo a conceder à sociedade a ordenação que esta não conseguia se impor ${ }^{69}$. Tem-se, então, que, ao contrário do quanto ocorria no Estado Liberal, a realidade do século $\mathrm{XX}$, com a crescente dependência da sociedade em relação às prestações estatais, tornou impossível a consideração de que ambos são autônomos e detentores de ordenamentos distintos e antagônicos ${ }^{70}$, de tal modo que se impôs uma interpenetração entre Estado e sociedade. Nas palavras de MANUEl GarcíA-PELAYO:

\begin{abstract}
"Em resumo, Estado e sociedade já não são sistemas autônomos, autorregulados, unidos por um número limitado de relações e que recebem e enviam insumos e produtos definidos, mas dois sistemas fortemente inter-relacionados entre si através de relações complexas, com fatores reguladores que estão fora dos respectivos sistemas e com um conjunto de subsistemas interseccionados, do que são mostras o cumprimento de funções estatais através de empresas de constituição jurídica privada, a realização de importantes funções públicas pela via do contrato, a presença de representantes do setor privado nas comissões estatais e nos loci das decisões etc. (...) Na realidade se trata de uma nova proposição do problema clássico das relações entre o Estado e a sociedade que, em termos de abstração sistêmica, poderia expressar-se da seguinte maneira: o sistema estatal e o sistema social, sem prejuízo de sua respectiva autonomia, são partes de um metasistema, é dizer, há de considerá-los desde a perspectiva de um sistema mais amplo no qual cada um dos termos serve a finalidades complementares e possuem qualidades e princípios estruturantes igualmente complementares" ${ }^{, 71}$.
\end{abstract}

A sociedade, por seu turno, também passava por importantes transformações em tal período. À medida em que as diferenças sociais começam a se acentuar, a classe

\footnotetext{
${ }^{69}$ Nas palavras de MANUEl GaRCíA-PELAyo, "la sociedad ejercía uma acción coercitiva sobre el Estado dado que por su solo juego era incapaz de resolver los conflictos existenciales que albergaba en su seno o, dicho de otro modo, había perdido su capacidad de autorregulación y había de buscar en el Estado la acción reguladora de la que carecía. Y, em efecto, por todos los grupos de la sociedad cualquiera que fuera su status económico se postulaba enérgicamente, aunque em sentidos distintos y contrapuestos, la acción del Estado para dar a la sociedad el orden que ésta era incapaz de darse. En resumen, el Estado era incapaz de subsistir sin proceder a la reestructuración de la sociedad y la sociedad por su parte era incapaz de subsistir sin la acción estructuradora del Estado". (Las transformaciones..., cit., p. 24).

${ }^{70}$ MARIA JoÃo ESTORNINHO, A fuga..., cit., p. 39.

${ }^{71}$ Las transformaciones..., cit., p. 25.
} 
burguesa passa a encontrar nos proletários e camadas menos favorecidas adversários na condução dos rumos do Estado $^{72}$.

Formam-se grupo de pressão, que passam a exigir do Estado o atendimento aos seus interesses, que não mais se focam apenas nas questões de educação e saúde, mas também incluem aquelas ligadas à cultura, meio ambiente, direitos das minorias etc. Tais grupos, não são rivais do $E_{s t a d o}{ }^{73}$, mas, pelo contrário, pretendem utilizar a autoridade estatal para legitimar a acolhida de suas pretensões ${ }^{74}$, o que se dará mediante duas formas de institucionalização: (i) de um lado, tais grupos pressionam o Estado para que este positive na legislação as suas pretensões; (ii) de outro, o que ocorrerá mais a partir do final da década de 80 e início do século XXI, como decorrência da primeira forma de institucionalização das pretensões, tais grupos passam a buscar uma interpretação normativa que obrigue o Estado a realizar suas pretensões, o que levará à judicialização de tais pretensões ${ }^{75}$. Interessa-nos, para a presente parte do estudo a análise da institucionalização de pretensões via positivação do direito, ante as alterações que provoca na legalidade e na separação das funções do Estado.

Na medida em que os grupos não pretendem digladiar com o Estado, mas sim se valer da sua estrutura para obter suas finalidades, é necessário que os instrumentos jurídicos sejam manejados em prol dos grupos de pressão. Afinal, é por meio da lei ou do ato administrativo que a manifestação legítima do Estado é exteriorizada.

\footnotetext{
72 Conforme aponta ODETE MedAUAR, a universalização do sufrágio, antes censitário, permitiu que os representantes das classes menos abastadas pudessem concorrer aos cargos eletivos do Legislativo, formando-se os partidos políticos com ideologias diversas da mera manutenção da liberdade e da propriedade. Ao mesmo tempo, os sindicatos de empregados passaram a exercer pressão sobre o Estado para garantir melhores condições de vida aos trabalhadores. "Por influência das idéias e dos partidos socialistas reivindicava-se intensamente que a igualdade formal se tornasse real, que as liberdades afirmadas nos textos constitucionais tivessem efetividade, que houvesse justiça social, que se assegurasse o suficiente para as necessidades básicas da vida." (O direito administrativo em evolução, cit., p. 83).

${ }^{73}$ FERNANDO DíEZ MORENO, EI Estado social, 2004, p. 79.

${ }^{74}$ Vale notar que tal reconhecimento da pluralidade social e da sua interpenetração com o Estado é a principal característica que diferencia tal período do assistencialismo do Antigo Regime. Com efeito, a noção de que o Estado deveria ser o responsável pela garantia do bem estar dos indivíduos, o que implicava uma assunção maior de atividades por ele para satisfazer tais necessidades foi marca típica do Estado Absoluto (cf. FernANDo DíEZ Moreno, El Estado..., cit, p. 29-32, e ReINHOLD ZiPPELIUS, Teoria geral do estado, $3^{a}$ ed., 1997, p. 370). No entanto, tal forma de Estado, o precursor do chamado Estado Moderno, não era admitida a pluralidade de grupos e de interesses sociais, muito menos a sua interpenetração destes com o Estado. A esse respeito, ensina Floriano de Azevedo Marques Neto que "é pressuposto do Estado Moderno um viés de universalidade e homogeneidade da sociedade. Para que se construa o discurso da Modernidade é imprescindível que a sociedade seja vista como um todo uniforme, monolítico, homogêneo, ungido por uma racionalidade que lhe dá coesão interna". (Regulação estatal..., cit., p. 115).

${ }^{75}$ A esse respeito conferir CELSO FERNANDES CAMPILONGO, Interpretação do direito e movimentos sociais, Rio de Janeiro: Elsevier, 2012, especialmente p. 73 e seguintes.
} 
O Estado, cuja manifestação se dá na seara jurídica para ser legítima, passa a ser o principal mediador entre os diversos grupos antagônicos, sendo a exteriorização da decisão estatal por agir de determinada forma um ato jurídico (lei ou ato administrativo), que irá servir de coordenador dos diversos interesses conflitantes ${ }^{76}$. Afinal, afirma REINHOLD ZIPPELIUS, "o governar e o legislar no Estado pluralista são um negociar contínuo, caso a caso, de compromissos entre forças e opiniões conflitantes" $" 77$.

Também importantes as considerações de PAULO OTERO:

\begin{abstract}
"Verificando-se que cada grupo pretende fazer valer os respectivos interesses nas instâncias decisórias públicas, o Estado aparece agora como interlocutor junto aos diversos grupos de interesses económicos, sociais e culturais existentes na sociedade, encontrando-se a legitimidade das suas próprias decisões normativas e não normativas num procedimento negocial visando obter o consenso dos 'parceiros sociais' que, implementando uma política de 'concertação social', traduzem, deste modo, uma nova visão orgânica da sociedade, qualificada já de 'democracia neocorporativa' ou de 'neocorporativismo", 78 .
\end{abstract}

A lei, neste contexto, passa a ser um instrumento do Estado para legitimar a sua atuação. De instrumento de garantia do cidadão, característica típica do Estado Liberal, a lei passa a ser a legitimadora da atuação estatal que, visa, na realidade, à consecução de um bem, de uma finalidade, como a diminuição das desigualdades sociais, a intervenção no domínio econômico, a proteção do meio ambiente, dos consumidores etc. A lei se torna instrumento político, posto pelo Estado para a concretização de uma

\footnotetext{
${ }^{76}$ A respeito desse cenário e dos motivos que levam à inflação legislativa, fundamental o magistério de REINHOLD ZIPPELIUS: "A fim de transformar as aspirações das forças sociais e políticas em realidade jurídica, é necessário uma lei, um acto administrativo ou um outro acto jurídico em que possam estar ponderados os mais variados interesses e influências. Neste sentido, uma lei, p. ex., pode ser o resultado das múltiplas forças económicas, ideológicas e confessionais que colidem no seio da entidade legislativa. As competências integram, no Estado moderno, um sistema homogéneo, estando submetidas à mesma supremacia das competências. Em resumo, a indiscutível pluralidade das forças políticas e sociais desenvolve a sua eficácia jurídica numa ordem homogénea de competências jurídico-públicas. (...) A ordem jurídica serve como esquema para uma canalização e coordenação específica dos interesses e das influências existentes numa comunidade. Se estas pretendem ser juridicamente eficazes, devem manifestar-se por intermédio de competências jurídicas. Desde que os poderes sociais não tenham força para romper por via revolucionária a ordem jurídica e constitucional vigente, ficam condicionados a fazer valer as suas influências dentro do esquema da ordem jurídica, não podendo, mesmo facticamente, - dada a profunda organização do moderno aparelho do poder estatal - subtrair-se à aplicação do direito nacional. (Teoria..., cit, p. 310).

${ }_{77}^{77}$ Teoria..., cit., p. 311.

${ }^{78}$ Legalidade..., cit., p. 140.
} 
política governamental, sem que possua qualquer valor ou finalidade intrínseca à norma, mas somente dentro do contexto do programa para o qual foi idelizada ${ }^{79}$.

Na medida em que há mais grupos de pressão e que estes grupos necessitam da lei para legitimar e institucionalizar o atendimento às suas pretensões pelo Estado, que, por sua vez cresce em tamanho institucional e passa a chamar para si a função tanto de realizador das necessidades sociais, quanto de solucionador dos conflitos entre classes e grupos antagônico, assiste-se a três consequências muito bem apontadas por MANUEL GARCÍA PELAYO ${ }^{80}$ : (i) a lei não possui como único objeto os valores jurídicos, mas passa a girar em torno de outros valores, de tal modo que "pode converter-se em elemento auxiliar para a consecução de outros valores, passando assim a ser um instrumento para a execução de decisões de espécies distintas" ${ }^{" 1}$, tais como a econômica, a ambiental, a social etc; (ii) sendo a lei um meio de atuação do Estado na formulação e aplicação das políticas estatais, o elemento central da ação estatal deixa de ser o Direito e passa a ser o sistema de decisão pública adotado pelo Estado, o que implica no inegável crescimento da política enquanto objeto de estudo; (iii) a legislação tende a aumentar tanto em quantidade como em diversificação de matérias tratadas, o que poderia levar à situação limite na qual a grande acumulação de leis levaria à própria ausência de segurança jurídica, razão de ser da legislação.

Em tal cenário, o Direito infla. Questões que para o Estado Liberal seriam solucionadas no campo da política ou da economia, por exemplo, passam a ser atraídas pelo âmbito jurídico. Todas as pretensões dos grupos de pressão acolhidas pelo Estado, seja quais forem os seus substratos, passam a ser regradas pelo Direito, como que, se num passe de mágica, ao serem exteriorizadas por um comando jurídico, tais pretensões fossem autoaplicáveis e de vigência imediata ${ }^{82}$.

Ainda neste plano, a lei passa por um processo de desprestígio. Com efeito, com a finalidade de pacificar a sociedade, o legislador passa a incorporar na lei

\footnotetext{
${ }^{79}$ Manuel GonçAlves Ferreira Filho, Estado de direito..., cit., p. 47-49.

${ }^{80}$ Las transformaciones..., cit., p. 63.

81 FERnANDo DíEz MoReno, El Estado Social, cit., p. 146. No original: “... puede convertirse en elemento auxiliar para la consecusión de otros valores, pasando así a ser um instrumento para la ejecución de decisiones de distinta espécie".

${ }^{82}$ A respeito da expansão do Direito sobre todos os setores da sociedade, cf. JúLIO AURÉLIO VIANNA LOPES, A invasão do direito: a expansão jurídica sobre o Estado, o mercado e a moral, Rio de Janeiro: Editora FGV, 2005.
} 
interesses conflitantes sem que decida, ex ante, qual deles é o vitorioso, colocando propositadamente no texto legal referências abertas e que deverão ser colmatadas pelo aplicador quando da verificação no caso concreto do interesse que deve prevalecer. Nesse passo, ao invés de conceder certeza aos cidadãos, a lei delega àquele que irá decidir o caso concreto de conflito (o administrador ou o Juiz), a tarefa de definir como ponderar os interesses conflitantes.

Logo, ao invés de equacionar ex ante os conflitos sociais, o que concederia segurança e estabilidade às relações jurídicas, o legislador determina que a Administração ou o Judiciário deverão definir ex post qual o interesse prevalente em determinado caso, o que implica na necessidade de interpretação do direito posto e ponderação dos interesses conflitante, o que gera insegurança jurídica e falta de efetividade da norma. A banalização da lei, que é instrumento para tratar de todos os assuntos da sociedade implica na perda do respeito que nutriu no período liberal do Estado de Direito ${ }^{83}$.

Ademais, a inflação legislativa possui como característica a positivação de interesses sociais de caráter eminentemente técnicos, que devem ser resolvidos de forma cada vez mais rápida, em sentido oposto ao lento e demorado processo legislativo. Com efeito, ao tratar de assuntos da sociedade tais como meio ambiente, direitos do consumidor, direitos da criança e do adolescente, ordem econômica e social etc., o

\footnotetext{
${ }^{83}$ GUSTAVO BINENBOJM, Uma teoria do direto administrativo, $2^{\mathrm{a}}$ ed., 2008, p. 128. A respeito da perda de segurança jurídica e de efetividade da norma, valiosas as considerações de Paulo Otero que, a despeito de longas, são colacionadas na íntegra ante a íntima relação com a temática ora tratada:"Neste último contexto [de desprestígio da lei pelas contradições intrínsecas que o texto normativo deve conter como fruto da negociação legislativa dos grupos conflitantes], verifica-se que, ao invés aquilo que sucedia no séculos XVIII e XIX, as sucessivas alterações legislativas conduzem a um modelo instável de legalidade administrativa, que faz do Direito Administrativo um campo de batalha dos partidos políticos e interesses de grupos. Num tal cenário de interesses concorrentes e contra-interesses sobre o sentido disciplinador de certa matéria apenas se consegue alguma estabilidade se o texto das leis incluir referências literais habilitadoras de uma argumentação justificativa da satisfação das diversas pretensões formuladas e em conflito. Surgem no texto da lei, deste modo, ambiguidades terminológicas intencionais, obscuridades propositadas e lacunas conscientes. Remete-se para as teorias da argumentação a defesa daquela que será a solução mais conforme à lei, sacrificando-se a certeza e a uniformidade na concretização aplicativa do Direito ao caso concreto em nome do consenso político e social: o procedimento decisório absorve e subverte a razão de ser da lei. A perfeição da lei cede agora lugar a uma temporária paz social que se visa obter com um texto normativo obtido num certo momento de consenso entre alguns dos interessados mais reivindicativos. A verdade é que a lei resultante de todo este procedimento legitimador, apesar de algumas vezes alheio à melhor prossecução do interesse público, não tem nada de perfeito, nem traduz revelação de qualquer verdade absoluta: a legalidade administrativa mostra-se contingente, precária e eivada de interesses contraditórios". (Legalidade..., cit., p. 161).
} 
legislador é limitado pela falta de conhecimentos técnicos, o que o obriga a, durante o trâmite do projeto de lei, ouvir comissões técnicas e diversos setores da sociedade civil interessados no assunto tratado pela futura lei, fatores que tornam lento o processo de aprovação da norma ${ }^{84}$.

Nesse passo, o legislador é incapaz de prever na lei todas as hipóteses de aplicação e de conceder ao administrador a descrição precisa de como agir em cada caso concreto. O texto legislativo passa, então, a ser cada vez mais aberto à interpretação do aplicador para solucionar, no caso concreto, a melhor alternativa para adequar a norma ao caso. Deste conjunto de falhas do processo legislativo (falta de tecnicidade e falta de celeridade), ganha vigor o protagonismo da Administração Pública através (i) do aumento da competência regulamentar, (ii) do aumento da estrutura administrativa e (iii) da discricionariedade administrativa, tanto na edição do regulamento, quanto na emissão de atos concretos.

Diversamente do que ocorreu no período do Estado Liberal, no qual, conforme visto, o protagonismo era do Legislativo, a necessidade de ação rápida para solucionar conflitos sociais, que guardam em si interesses divergentes e complexidade técnica, colocou o Executivo no centro da atuação estatal, por ser o responsável pela execução de ações com a finalidade de solucionar os conflitos sociais. Passa-se da nomocracia, sistema no qual o objeto central do Estado é a edição da norma jurídica, para a telocracia, no qual o ponto central da atuação estatal é o atendimento às finalidades públicas previstas nos textos normativos.

\footnotetext{
${ }^{84}$ Conforme lição de CLÈMERSON MERLIN CLÈVE, "Com a sociedade técnica, o tempo adquiriu velocidade. A sociedade passou a exigir respostas prontas e rápidas para questões não poucas vezes novas e particularizadas. Sem contar o fato de que os assuntos que 'estão penetrando nas pautas estatais revestem-se cada vez mais de maior complexidade'. A administração vê-se compelida a socorrer-se do auxílio de especialistas que, em nome da objetividade ou infalibilidade da ciência ou técnica, nem sempre estão dispostos a dialogar com os integrantes do Legislativo. Afinal, há uma radical oposição entre o discurso do tecnocrata, auxiliar do governo, e o jurista ou político. Enquanto aquele tem em mira o resultado, estes se preocupam com a legitimidade da decisão (o processo de tomada da decisão). Há uma tensão permanente entre o discurso do resultado ou dos fins do tecnocrata e o discurso dos meios e da legitimidade da decisão professado pelo jurista ou pelo político, pelo menos pelo político no melhor sentido da expressão. (...) O vir à tona do Estado social e da sociedade técnica dificulta o exercício, pelo parlamento, da função legislativa. Primeiro, porque o Estado social e a sociedade técnica exigem do Legislativo um preparo técnico que não pode ser encontrado num órgão cuja composição não é de especialistas, e sim de mandatários eleitos. Depois, porque o processo legislativo nem sempre pode ser célere. De uma estrutura colegial, formada por um número nem sempre pequeno de congressistas, não se pode exigir que a tomada de decisão seja tão rápida como a do Executivo". (Atividade legislativa do Poder Executivo, $3^{\mathrm{a}}$ ed., 2011, p. 50-51).
} 
Como bem aponta FÁBio Konder COMPARATO ${ }^{85}$, a necessidade do alcance de finalidades pública por meio de programas governamentais implica na alteração da lógica da separação de funções realizada pelo Estado Liberal, que tinha no Legislativo o protagonista. Ao buscar a sua legitimidade não mais na emissão da lei como expressão da vontade geral, mas sim na execução de finalidades coletivas, o critério a ser utilizado para a separação das funções estatais deixa de ser a produção do texto normativo e passa a ser a realização de políticas ou programas de ação governamental.

Nesse passo, foram criados diversos órgãos centrais, além de entes com personalidade jurídica própria, com a finalidade de atuar em setores específicos, muitos dos quais até então reservados apenas à iniciativa privada, como o caso das atividades comerciais e industriais. Passa-se a ter uma administração descentralizada, com diversos centros de poder autônomos, dotados de personalidade jurídica, orçamento, servidores, competências etc. próprios, possuindo, então, menor grau de ligação e dependência do poder central ${ }^{86}$.

Esta realidade foi muito bem percebida por MASSIMO SEVERO GIANNINI ${ }^{87}$, ao tratar do surgimento do Estado pluriclasse, que gerou uma ploriferação da Administração Pública, antes concebida, no Estado burguês, para ser a menor possível, com a menor intromissão no âmbito social. Assim, no decorrer do Século XX, "quase toda a atividade humana encontra correspondência dentro da administração pública: interesses científicos, religiosos e culturais, assim como interesses econômicos, produtivos ou profissionais, acabam tendo um ponto de apoio em algum Poder Público legalmente reconhecido".

À inflação legislativa soma-se a inflação de entes administrativos. É a época na qual ganham corpo e número as empresas estatais, como forma de intervenção direta do

\footnotetext{
85 Ensaio sobre o juízo de constitucionalidade das políticas públicas, in Revista de Informação Legislativa, n. 138, abr/jun. 1998, p.43-44.

${ }^{86}$ Conforme a lição de Odete Medauar: "A administração por entes gerou, então, um panorama de difusão de centros administrativos, um panorama de fragmentação. À concepção de Administração unificada, típica do século XIX, seguiu-se a Administração desagregada, a ponto de suscitar dúvidas quanto à sua controlabilidade pelo poder central; da imagem da pirâmide para cada ministério passou-se à imagem de uma rede de pirâmides, acrescentando-se ainda o rol de órgãos destituídos de personalidade jurídica, como staffs consultivos, sistemas de controle horizontal, grupos formados em torno de projetos, comissões e conselhos de vários tipos. A confusão organizacional torna-se em regra." (O direito administrativo em evolução, cit., p. 127).

${ }^{87}$ Diritto amministrativo, vol. I, 1993, p. 49-50.
} 
Estado no domínio econômico, com a finalidade de (i) atuar em setores nos quais ou eram considerados estratégicos para a economia nacional, ou (ii) de garantir a prestação de atividades de interesse coletivo, mas que, em virtude de altos investimentos de retorno econômico duvidoso, não atraíam a iniciativa privada para a prestação, o que implicava na necessidade de prestação direta pelo Estado.

Ao atuar na economia como agente econômico, o Estado teve que assumir a forma das empresas privadas, uma vez que a conformação de pessoas de direito público não possuía o condão de fornecer a característica de eficiência que marcam as pessoas privadas atuantes no cenário econômico ${ }^{88}$. Surgem, então, as empresas estatais em virtude da necessidade do Estado intervir na ordem econômica e social com vistas à transformação do cenário então vigente, o que implicava na assunção da forma de entes de direito privado. De acordo com Themístocles BRANDÃo CAVAlCANTi ${ }^{89}$, o desenvolvimento das empresas estatais está ligado à assunção de uma maior gama de atividades pelo Estado, uma vez que "São novos setores de atividade que foram abertos à sua iniciativa, são novos os tipos de atividade, que exigem uma diferenciação maior na estrutura dos serviços, no seu funcionamento, na organização de seu patrimônio, na sua administração". Assim, sendo a atividade do Estado não mais voltada àquelas típicas e tradicionais, mas sim atividades industriais e comerciais, foi necessária a criação de entidades regidas pelo direito privado, ainda que influenciadas por princípios de direito público ${ }^{90}$.

Aponta ANDRÉ DE LAUBADÈRE ${ }^{91}$ que no período entre as duas guerras mundiais, o Estado atuava na economia predominantemente por meio de pessoas jurídicas de direito público, sendo que, após a Segunda Guerra Mundial, o Estado teve que lançar mão de outras figuras para a intervenção econômica, uma vez que as figuras tradicionais não se mostravam mais suficientes para tal função. Aponta o autor as seguintes razões para tal necessidade: (i) em primeiro lugar, as atividades de intervenção se tornaram cada vez mais diversificadas, de tal modo que as figuras clássicas da intervenção administrativa, rígidas e uniformes, tornaram-se insuficientes;

\footnotetext{
${ }^{88}$ ERnST FORSTHOFF, Tratado..., cit., p. 114 e segs.

${ }^{89}$ A intervenção do Estado e as suas conseqüências na estrutura administrativa, in Themístocles Brandão Cavalcanti, Carlos Medeiros Silva e Victor Nunes Leal, Cinco Estudos, 1955, p. 48.

${ }^{90}$ Idem, p. 52.

${ }^{91}$ Droit public économique, 1974, p. 424-427.
} 
(ii) em segundo plano, começa a se intensificar a desconfiança na atuação dos estabelecimentos públicos administrativos, sentimento que já havia começado a surgir no entre guerras; (iii) além disso, surge a preocupação de utilizar organismos profissionais para a gestão das atividades intervencionistas, profissionalizando tais prestações $^{92}$.

Nesse cenário, aponta LOREnZO MARTín-RetoriLlo BAQUER, que a consequência do aumento das tarefas atribuídas ao Estado é que as principais atuações estatais se dão por meio da Administração Pública, de tal forma que esta "há de ser considerada como a mais importante 'organização' de quantas atuam no âmbito do ordenamento estatal" ${ }^{\prime 93}$. Assim, desloca-se o eixo de importância central do Legislativo ao Executivo, uma vez que o Estado deve agir de modo cada vez mais direto no domínio econômico e social, saindo da sua inação típica do período liberal.

No que se refere à discricionariedade administrativa, esta também sofre grande impacto em tal período, uma vez que o caráter mais aberto das leis emanadas pelo Legislativo acaba atribuir ao agente público, no momento de aplicação da norma, a competência para definir como será realizada a atuação administrativa. Em virtude do aumento das funções atribuídas ao Estado, que são realizadas pela função administrativa, percebe-se que esta é muito mais complexa do que a mera execução

\footnotetext{
92 Anota ainda ANDRÉ DE LAUBADÈRE, que a utilização de tais figuras que trouxe uma complexização à "morfologia das instituições" 92 encontrou terreno jurídico na jurisprudência do Conselho de Estado dos anos anteriores à Segunda Guerra, que separou os elementos orgânico e material do serviços público, admitindo a gestão deste por um organismo privado (arrêt Caisse primaire, de 13.05.1938), além de reconhecer a existência de empresas privadas de interesse geral (arrêt Vézia, de 20.12.1935). (Droit public économique, cit., p. 425).

No Brasil, tal tendência também foi observada, com a criação de diversas empresas estatais para a prestação dos mais diversos serviços. Marca da época dos anos de 1930 em diante, a estatização da economia de dava através da constituição em favor da União de monopólios de determinadas atividades, conforme previsto nos artigos 116 da Constituição de 1934, 146 da Constituição de 1946, 157, §8 $8^{\circ}$, da Constituição de 1967, e 163 da EC n 0 01/69, ou através da previsão expressa da nacionalização de setores econômicos, como fez o art. 144 da Constituição de 1937.

Durante a vigência de tais textos constitucionais, diversas empresas estatais foram criadas, como bem aponta Caio Tácito, tais como o Instituto de Resseguros do Brasil (1939), a Companhia Siderúrgica Nacional (1941), a Companhia Vale do Rio Doce (1942), Petrobrás (1953) e Eletrobrás (1961), sendo estas duas últimas criadas em expresso regime de monopólios de suas atividades. (As empresas estatais no direito brasileiro, in Temas de Direito Público, $1^{\circ}$ vol., 1997, p. 680).

${ }^{93}$ La configuración jurídica de la administración pública y el concepto da "daseinsvorsorge", in Revista de Administración Pública, n. 38, maio/agosto 1962, p. 44-45 - traduzimos. No original: "De ahí que la Administración Pública haya de ser considerada como la más importante <<organización〉> de cuantas actuán en el ámbito del ordenamiento estatal".
} 
mecânica de enunciados de lei, ou mesmo que o administrador poderia continuar a assistir passivamente aos conflitos dos diversos grupos sociais.

Torna-se necessário agir de modo rápido e eficaz, o que, conforme se viu acima, é incompatível com o moroso processo legislativo. De outro lado, o aumento da complexidade social torna impossível ao legislador prever, na norma geral e abstrata, todas as hipóteses de atuação. A atuação do administrador com certa margem de liberdade, dentro dos padrões concedidos pela própria lei, aparece como corolário do próprio exercício da função administrativa.

Como destaca ERNST FORSTHOFF ${ }^{94}$, a atuação administrativa é diferente caso se trate de atuar de acordo com mandato normativo concreto ou uma norma mais aberta, chamada pelo autor de norma geral. No primeiro caso, a Administração atua de acordo com a execução, a realização do comando normativo. No segundo, por outro lado, a atuação administrativa se dará de acordo com considerações práticas e operacionais, externadas por meio de uma série de atos administrativos, que não estão detidamente especificados na lei, adquirindo papel preponderante os conhecimentos técnicos, a experiência e a tradição.

A edição de leis com conteúdos cada vez mais abertos à interpretação e aplicação pela Administração, consequentemente, com maior espaço para as decisões discricionárias, leva àquilo que PAULO OTERO ${ }^{95}$ denomina de normas legais em branco, em alusão às normas penais em branco do direito penal. Aponta o administrativista português que tais normas são compostas de abertura e indeterminação que deverão ser densificadas pelo administrador no momento da aplicação normativa, o que implica na existência de "uma verdadeira remissão habilitante do poder legislativo para o poder administrativo completar, desenvolver ou concretizar a legalidade" ${ }^{96}$, de acordo com o limites postos pela própria lei "incompleta". Ao tema da discricionariedade administrativa retornaremos no capítulo II.

\footnotetext{
${ }^{94}$ Tratado..., cit., p. 96-97.

${ }^{95}$ Legalidade..., cit., p. 893-899;

${ }^{96}$ Ob. cit., p. 897.
} 
No entanto, a despeito do significativo aumento das atividades da Administração Pública, o controle jurisdicional da função administrativa, nos países que adotaram a unidade de jurisdição, e especialmente no Brasil, permaneceu tímido. Ao mesmo tempo em que o número de leis cresce exponencialmente e a própria atividade judicial ganha expansão, decidindo questões não mais apenas ligadas à liberdade e propriedade, como ocorria no período liberal, mas também ligadas a outros tipos de questões, tais como os conflitos trabalhistas ${ }^{97}$, o controle judicial da atividade encontrase limitado ${ }^{98}$, seja pelo apego excessivo ao formalismo, de tal forma que, se a lei havia permitido uma escolha de atuação pela Administração, esta estaria legitimada a agir por qualquer das formas legalmente autorizadas, seja pelo conceito de "mérito" do ato administrativo, enquanto campo imune a qualquer tipo de verificação judicial. A tal tema - controle judicial da administração - retornaremos posteriormente no capítulo IV do presente trabalho.

De qualquer modo, as principais características de tal período importantes para o presente trabalho são: (i) a intervenção direta do Estado no domínio econômico e social, como agente participante através da criação de entes e órgãos que prestarão os mais variados tipos de serviços públicos e atividades econômicas; (ii) em decorrência disto, o agigantamento do aparato estatal; (iii) uma maior atividade normativa da Administração Pública, em virtude da edição de leis com textos cada vez mais abertos e de necessária completude pelo órgão executor da ação neles previstas; (iv) o aumento dos espaços para a discricionariedade administrativa, seja no que se refere ao conteúdo dos regulamentos, seja no que tange à atuação concreta da Administração; e (v) como consequência de todas essas características, a inversão na ordem de importância da separação de funções, sendo o Executivo colocado como o centro da atuação estatal.

\footnotetext{
${ }^{97}$ É justamente neste período em que é criada no Brasil a Justiça do Trabalho, por meio do Decreto-Lei ${ }^{\circ}$ 1.237/1939, cujo artigo $1^{\circ}$ determina que "Os conflitos oriundos das relações entre empregadores e empregados, reguladas na legislação social, serão dirimidos pela Justiça do Trabalho".

${ }^{98}$ Maria Sylvia Zanella di Pietro, Discricionariedade..., cit., p. 25. Durante décadas, o entendimento que vigorou no direito público brasileiro foi o de que o Judiciário somente poderia analisar os aspectos da legalidade do ato administrativo, o que implicava na aferição apenas das formalidades extrínsecas do ato, quais sejam, competência, forma e respeito às prescrições legais do agir administrativo. Neste sentido, por exemplo, Alcides Cruz, no início do século XX, afirmava que:

"Todo acto administrativo deve revestir-se de três elementos:

$1^{\circ}$ - O de emanar de uma autoridade administrativa, isto é, ha necessidade de que a pessoa de onde baixa ele, se ache no exercício de funcções inherentes a algum cargo, conferidas pelo direito público; $2^{\circ}$ - O de enquadrar-se nas attribuições da autoridade administrativa, ou nas de qualquer agente ou corporação que tenha jurisdicção administrativa;

$3^{\circ}$ - O de estar sempre em conformidade com o direito, e a este submetido." (Direito administrativo brazileiro, 1914, p. 38).
} 


\section{I.B.3 - O Estado Social de Direito de Atuação Sobre a Economia}

Chamamos de Estado Social de Direito de atuação sobre a economia o Estado que se apresenta a partir do final dos anos 80 do século $\mathrm{XX}$, também chamado pela doutrina de Estado Pós-Social, Estado Regulador, Estado Neoliberal, entre outras.

Preferimos tal denominação, pois, a nosso ver, as principais características do Estado Social apontadas no item precedente - intervenção do Estado nos domínios econômico e social, com a finalidade de diminuir as desigualdades sociais e promover o desenvolvimento da população $0^{99}$; mitigação da separação Estado-sociedade, com o reconhecimento por aquele da pluralidade de grupos e interesses conflitantes; e atuação estatal cada vez mais centrada na Administração Pública - continuam a existir em tal cenário, tendo, no entanto, sido modificadas pela chamada crise econômico-gerencial do Estado, o que fez aumentar a importância do papel do Poder Judiciário na dinâmica da separação de funções, conforme será visto.

O Estado no decorrer da década de 1980 ingressa numa crise institucional gerada por ele próprio. $\mathrm{Na}$ ânsia de tentar atender a todas as demandas sociais o Estado se tornou o garante universal de todas as mazelas sociais e econômicas presentes e futuras, o que o obrigou a aumentar a sua estrutura e a quantidade de prestações realizadas em prol da população. A necessidade de legitimação do Estado pelas prestações conferidas aos privados implicava, ainda que os administradores públicos e a população não percebesse, na necessidade do dispêndio de gastos realizados com o dinheiro público.

Em tal quadro, como num movimento cíclico, o aumento das demandas sociais implica no aumento do aparato estatal e no aumento das prestações realizadas pelo Estado, o que, por sua vez, aumenta as demandas sociais em outras áreas, seja por novos

\footnotetext{
${ }^{99}$ Não vemos, portanto, antinomia entre o Estado Social do período anterior e o atual, no que se aos objetivos da atuação estatal no ou sobre o domínio econômico, uma vez que ambas possuem como finalidade a diminuição das desigualdades sociais, ainda que o façam por meios diferentes, o que pode ser observado pelo fato de que todas as Constituições brasileiras a partir de 1934, com exceção da de 1937, trouxeram dispositivos a respeito da ordem econômica, baseados tanto na livre iniciativa, quanto na valorização do trabalho ou da dignidade humana, a despeito de aquelas anteriores ao Texto de 1988 terem um caráter de muito maior intervencionismo direto do Estado na economia do que a atual, conforme já demonstramos.
} 
grupos sociais, seja por aqueles que já foram atendidos anteriormente, mas que passam a realizar novas demandas em face do Estado, justamente por terem obtido êxito na institucionalização de suas demandas anteriores ${ }^{100}$, seja por aqueles que se viram atingidos em seus interesses pela ação estatal em outro campo.

Assim, por exemplo, a construção de uma usina hidroelétrica, que vem a atender aos anseios da população pelo fornecimento de energia em maior quantidade e qualidade e dos grupos empresarias para a expansão da produção e dos lucros, acaba por gerar efeitos sobre o meio ambiente, a população a ser desapropriada para a inundação da área do reservatório de recursos hídricos, de população indígena, o que implica na manifestação de grupos ambientalistas, pró-indígenas, de defesa dos moradores da região e assim por diante.

Tal aumento desenfreado das demandas sociais, ocorrida também pela geração de efeitos em cadeia de uma ação estatal, implica na necessidade de um maior aumento dos gastos públicos para conter tais manifestações, com a finalidade de mitigar a crise de governabilidade. A necessidade de diálogo e de atendimento a demandas sociais faz com que o Estado tenha que se tornar cada vez mais um provedor de benesses. Nesse passo, ao mesmo tempo em que a grande quantidade de entes criados para a prestação de serviços gerava gastos, o atendimento às demandas sociais implicava na concessão de verdadeiros direitos subjetivos aos cidadãos, que não poderiam ser posteriormente suprimidos, sob pena de geração do caos social ${ }^{101}$.

No entanto, como é sabido, os recursos são finitos e, mais cedo ou mais tarde, a conta decorrente do inchaço do aparato estatal teria que ser paga, o que ocorreu nas décadas de 1980 e 1990 em praticamente todo o mundo ocidental, quando da chamada crise fiscal do Estado.

\footnotetext{
100 Conforme Floriano DE AZEVEdo MARQues NeTO, ao analisar os movimentos sociais e suas reivindicações em face do Estado, "particularmente a partir do êxito no atendimento de parte das demandas que levavam ao agrupamento inicial, tais movimentos adquirem uma certa institucionalidade interna e alguma estabilidade organizacional, podendo, inclusive, espraiar seu raio de ação para fora dos limites e objetivos inicialmente traçados. Neste segundo momento tais movimentos passa a pelejar não mais apenas por questões concretas do seu dia-a-dia, incorporando também pautas de reivindicações "pósmaterialistas', como a preservação do meio ambiente, o pacifismo, a condição de gênero e outras tantas". (Regulação estatal..., cit., p. 117-118).

${ }^{101}$ JOSÉ EDUARDO FARIA, O direito na economia globalizada, $1^{\mathrm{a}}$ ed., $4^{\mathrm{a}}$ tir., 2004, p. 120-121.
} 
As empresas estatais, ao longo da segunda metade do século $\mathrm{XX}$, se tornaram uma das principais fontes de gastos de recursos públicos. Ao invés de garantirem uma atuação estatal de acordo com padrões e critérios típicos da iniciativa privada - a principal razão da criação de tais entes -, as estatais se tornaram a grande fonte de ineficiência do Estado ${ }^{102}$.

Assim, ao invés de contribuir para o crescimento econômico e industrial do Estado, as empresas estatais acabaram se tornando verdadeiras fontes de gastos desenfreados. Sendo deficitária a empresa, bastava ao gestor captar recursos junto à Administração central para sanear as contas, o que sempre foi repetido ano a ano nas estatais, notadamente nas brasileiras.

Ora, num cenário de contingência social, marcada pela intensa conflituosidade entre os grupos sociais pelo acesso aos recursos públicos, o que implica, como visto, no

\footnotetext{
${ }^{102}$ Aponta GASPAR ARIÑO ORTIZ que diversas razões levaram, e ainda levam, as empresas estatais a serem ineficientes, sendo que tal análise empírica, como o próprio autor consignou, pode ser verificada em diversos países e em diversas empresas. Como causas para a ineficiência das empresas estatais, que o autor chama de "casa sem amo", são apontadas: (i) aquilo que denomina de relaciones de agencia. Tal problema se resume à ausência de um proprietário da empresa estatal, uma vez que, sendo ela do Estado, pertence aos eleitores, que não possuem capacidade de direção e controle sobre a empresa. Assim, não há proprietários, mas meros agentes que agem de acordo com o título político derivado do processo eleitoral, o que permite a influência de burocratas, que pretendem aumentar seus campos dentro da empresa, e políticos, que veem na estatal uma possibilidade de reeleição e de assegurar votos; (ii) diante disso, a capacidade decisória resta diluída entre os gestores, os burocratas e os políticos, de tal modo que a responsabilidade também se dilui; (iii) a influência política nas estatais leva à rápida alteração dos presidentes, o que impede que haja possibilidade de planejamento a médio ou longo prazo; (iv) a síndrome da imagem, pela qual os Presidentes das estatais possuem grande preocupação com a imagem que eles e as empresas possuem, que despendem recurso e tempo no relacionamento com a mídia, sendo que as propostas de mudanças dos rumos e objetivos da empresa possuem apenas efeitos midiáticos; (v) falta de incentivos financeiros aos funcionários das empresas estatais ou utilização dos incentivos como forma de abuso de poder e influência política; (vi) ausência de controle de resultados e de objetivos definidos, o que torna os funcionários meros cumpridores de regras, sem preocupação com a boa execução dos serviços; (vii) manipulação dos resultados financeiros da empresa, com a finalidade de apresentar resultados positivos durante o mandato do presidente da estatal, gerando problemas a serem solucionados pelo próximo a ocupar o cargo; (viii) atuação dos buscadores de rendas, o que se manifesta ante a baixa exigência de retorno financeiro positivo das estatais e da facilidade em captar recursos junto ao Estado, o que permite, além de apadrinhamentos de aliados políticos na estrutura da empresa, a existência de altos salários aos dirigentes. Soma-se a isto o fato de que a sindicalização dos empregados das empresas estatais impede ou dificulta qualquer tentativa de reorganização dos cargos; e (ix) a impossibilidade de falência das empresas estatais, decorrente da certeza da ajuda estatal em caso de dificuldade financeira ${ }^{102}$, leva as empresas a não terem qualquer preocupação com a contenção de gastos, e a realizarem investimentos de alto risco ou em setores fora do objeto social inicial da estatal, gerando maiores prejuízos, ante a atuação fracassada em tais setores. (De la empresa pública a la empresa com participación pública: privatización o reforma? Quizas ambas cosas, in Revista de Administración Pública, n. 138, set./dez. 1995, p. 19-28).
} 
cada vez maior dispêndio de recursos do erário, tornou-se praticamente impossível, a manutenção dessas megaestruturas caras, ineficientes e dispendiosas, o que levou à crise fiscal do Estado.

Tal crise fiscal, por sua vez, levou a três fenômenos que nos interessam no presente estudo: (i) a retirada do Estado da atuação direta na economia através de empresas e entes, passando a atuar de modo subsidiário, através da republicização de atividades, abrindo campo para o surgimento das agências reguladoras e da maior atividade normativa da Administração; (ii) ao aumento da conflituosidade social, ante a impossibilidade do Estado atender a todos os anseios e prestações exigidas pela coletividade; e (iii) como decorrência de tal aspecto, a judicialização de tal conflito, tornando o Judiciário, ao lado da Administração, a principal função estatal.

No que se refere à retirada do Estado da prestação direta de serviços, é justamente neste momento que surgem as agências reguladoras nos países cujo direito administrativo tem origem no sistema europeu continental, como é o caso do Brasil ${ }^{103}$. E tal modelo não se deu de modo aleatório, sendo pautada por dois fundamentos.

Em primeiro lugar, a retirada do Estado da prestação direta de determinadas atividades econômicas teve como efeito a necessidade de atrair os privados para assumir tais encargos, o que gerou a necessidade de uma atuação estatal pautada por aspectos técnicos e econômicos do serviço do que pelas decisões políticas, que, por sua própria natureza, são variáveis de acordo com a vontade do governante, o que possui o nítido efeito de afastar os investidores privados ou majorar demasiadamente os custos da prestação $^{104}$, tendo em vista que os riscos do rompimento do contrato ou mesmo da sua

\footnotetext{
${ }^{103}$ Não que o modelo de regulação por agências fosse totalmente desconhecido pela doutrina pátria anterior a tal período, uma vez que, na década de 40 do século XX, BILAC PINTO destacava que uma das formas de garantir a efetiva regulação da prestação de serviços públicos se daria por comissões independentes, que hoje são as agências (Regulamentação efetiva dos serviços de utilidade pública, $2^{\text {a }}$ ed., atualizada por Alexandre Santos de Aragão, 2002, p. 34 e segs).

${ }^{104}$ A esse respeito são diretas as palavras de GUSTAVO BINENBOJM: "Com efeito, a superação da crise econômico-gerencial do Estado brasileiro, cujo auge se atingiu na década de 1980, passava pela reformulação das estratégias de intervenção do Estado na economia. Através de desestatizações, privatizações e flexibilização de monopólios, o modelo de Estado empresário, calcado em forte intervenção direta na economia, foi substituído, a partir dos anos 1990, pelo modelo de Estado regulador, cuja intervenção opera-se de modo indireto. O sucesso de aludida conversão dependia, contudo, de maciça atração do capital privado, e, para tanto, fazia-se imprescindível superar a histórica crise de credibilidade do país de suas instituições. Ou seja: era preciso vender o Brasil como um bom negócio, garantindo aos investidores a manutenção dos contratos celebrados e o direito de propriedade. Nisso
} 
brusca alteração por meio da mudança da vontade política serão precificados e embutidos pelo prestador nos custos do serviço. Assim, aponta VITOR RHEIN SCHIRATO $^{105}$ que "as agências funcionam como instrumento de mitigação dos riscos políticos inerentes a um determinado setor, uma vez que exercem (ou devem exercer) exclusivamente as funções de regular e fiscalizar determinado setor de acordo com as competências que lhe foram atribuídas, independentemente de critérios políticos".

De outro lado, as privatizações também levaram à quebra dos monopólios estatais sobre as referidas atividades, sendo permitida a prestação de serviços públicos por privados em regime de competição, inclusive em competição com o próprio prestador estatal $^{106}$, o que impede que a regulação seja feita pela própria empresa estatal que prestará o serviço, sob pena de frustração da competição que deve ocorrer em igualdade de condições.

Nesse sentido, Floriano de Azevedo MARques Neto aponta que o cenário de "fortalecimento do papel do regulador do Estado em detrimento do papel do Estado produtor de bens e serviços" ${ }^{107}$ levou tanto à retirada das empresas estatais da prestação de determinados serviços, como no caso das telecomunicações, quanto à permanência de tais entes como prestadores, mas em regime de competição com os privados, de acordo com as regras de mercado, como nos setores de energia elétrica e de petróleo. Assim, a grande relevância da retirada do Estado da prestação direta de bens e serviços é (i) a separação entre o regulador e o operador estatal no setor, e (ii) possibilidade de competição dos privados com o ente estatal (operador público), o que implica no surgimento da noção de regulação para a competição ${ }^{108}$. Logo, podemos concluir que a chamada privatização não implica obrigatoriamente na alienação das empresas estatais

reside, fundamentalmente, a razão da escolha pelo modelo de agências reguladoras: entidades com grau reforçado de autonomia, investidas de funções técnicas e, sobretudo, imunizadas das ingerências políticopartidárias". (Uma teoria..., cit., p. 252-253).

${ }^{105}$ A regulação para os serviços públicos como instrumento para o desenvolvimento, Interesse Público, n. 30, mar./abr. 2005, p. 84.

${ }^{106}$ No Brasil, o artigo 16 da Lei 8.987/95 deixou expressa a possibilidade de prestação de serviços públicos em regime de competição, ao dispor que “A outorga da concessão ou permissão não terá caráter de exclusividade, salvo no caso de inviabilidade técnica ou econômica justificada no ato a que se refere o art. $5^{\circ}$ desta Lei". O artigo $5^{\circ}$ mencionado no dispositivo trata do edital da licitação para a outorga da concessão ou permissão. A respeito da prestação de serviços públicos em regime de competição, cf. a excelente obra de VITOR RHEIN SCHIRATO, Livre iniciativa nos serviços públicos, Belo Horizonte: Fórum, 2012.

${ }^{107}$ Agências reguladoras independentes: fundamentos e seu regime jurídico, 2005, p. 29.

${ }^{108}$ Idem, p. 29-31. 
ao setor privado, mas poderá se dar também através da manutenção da existência de tais entes como integrantes da Administração indireta, que passam a atuar em regime de competição com as empresas privadas em dado setor ${ }^{109}$.

Na mesma linha, Vital Moreira e Fernanda MaÇÃS ${ }^{110}$ afirmam que "se antigamente existia uma mistura entre a intervenção directa do Estado na actividade econômica e as tarefas regulatórias", a quebra dos monopólios públicos e o ingresso dos agentes privados na execução dos serviços "trouxe consigo a necessidade de separar as funções de estabelecer regras de funcionamento desse mercado em relação à função de intervir directamente no mesmo enquanto sujeito económico".

A intervenção do Estado deixa de se dar na economia para se dar sobre a economia, com a estipulação de regras a serem seguidas pelos agentes privados, o que inclui as próprias empresas estatais ainda existentes e que participem da competição com os privados. E tal forma de atuação do Estado é diversa daquela que pautava a intervenção direta no domínio econômico.

A atuação do Estado nas atividades econômicas passa a ser pautada pelo princípio da subsidiariedade, segundo o qual a atuação da autoridade estatal é eventual, com a finalidade de estimular e fomentar os particulares a conduzirem suas atividades econômicas, não se justificando a intervenção direta do Estado no domínio econômico quando os particulares puderem e tiverem interesse em fazê-lo de maneira eficaz para a sociedade ${ }^{111}$.

\footnotetext{
${ }^{109}$ A respeito da inexistência de fórmula única para a realização da privatização, conferir EROS ROBERTO GRAU, A ordem econômica na constituição de 1988, $12^{\mathrm{a}}$ ed., 2007, p. 287-289.

${ }^{110}$ Autoridades reguladoras independentes: estudo e projecto de lei-quadro, 2003, p. 10-11.

111 Conforme RoberTo Dromi, "Deste modo, a subsidiariedade institucional, valor administrativo de ordem ou de distribuição, deve ser observada em sua dupla manifestação: por um lado, a que impede que o Estado suplante aos particulares à hora de satisfazer uma determinada necessidade social que pode ser assumida por estes, de modo razoavelmente eficaz; também implica que o Estado deve intervir, subsidiariamente, naqueles casos em que sua participação resulte imprescindível, ou seja, indubitavelmente conveniente, porque os particulares não podem levá-la a cabo. Por conseguinte, isso será realizado sem suprimir nem proibir de nenhum modo a atividade dos particulares". (Sistema jurídico e valores administrativos, p. 224-225). Na mesma linha, cf. MARIA SYLVIA ZANELLA DI PIETRO, Parcerias na administração pública, p. 15-22; JosÉ AlFredo DE Oliveira BARACHO, O princípio da subsidiariedade: conceito e revolução, Revista de Direito Administrativo, no 200, p. 21-54, especialmente, p. 42-48; SÉRGIO GUERRA, Direito administrativo e a nova hermenêutica: uma releitura do modelo regulatório brasileiro, Revista de Direito Administrativo, $\mathrm{n}^{\circ}$ 243, p. 168-207, especificamente, p. 196.
} 
Nesse quadro, o Estado passa a ter uma nova atuação, deixando de ser agente da atividade econômica e passando a regulá-la ${ }^{112}$, como agente externo capaz de impor regra que tenha por finalidade manter o equilíbrio do mercado, garantir a eficiência dos serviços públicos, tutelar os interesses públicos incidentes sobre determinada prestação etc. Conforme ensina JACQUES CHEVALLIER:

\begin{abstract}
"A regulação se distingue dos modos clássicos de intervenção do Estado na economia: ela consiste em supervisionar o jogo econômico, estabelecendo certas regras e intervindo de maneira permanente para amortecer as tensões, compor os conflitos, assegurar a manutenção de um equilíbrio do conjunto; pela regulação, o Estado não se põe mais como ator, mas como árbitro do processo econômico, limitando-se a enquadrar a atuação dos operadores e se esforçando para harmonizar as suas ações. A implantação dessa função pressupõe a reunião de diversas condições: uma posição de exterioridade relativamente ao jogo econômico; uma capacidade de arbitragem entre os interesses em jogo; uma ação contínua a fim de proceder aos ajustes necessários" ${ }^{113}$.
\end{abstract}

A moderna regulação estatal possui quatro vetores fundamentais ${ }^{114}$ que possuem importância central para o presente trabalho: (i) quanto aos pressupostos, a intervenção é mais pautada pela mediação de interesses do que pela imposição unilateral de objetivos e metas pelo Estado, o que implica na necessidade de um diálogo entre o regulador e os diversos agentes do setor regulado (operadores econômicos, consumidores etc.); (ii) quanto aos objetivos, os interesses albergados pela intervenção estatal deixam de ser os do Estado-Nação e passam a se identificar com a sociedade, ou seja, tanto os interesses dos agentes econômicos quanto dos consumidores; (iii) quanto aos instrumentos, a regulação estatal implica na necessidade de que o Estado crie mecanismos que permitam a interlocução com os interesses conflitantes no setor regulado, o que implica na necessidade de procedimentalização da atividade regulatória para a permeabilidade dos interesses conflitantes; e (iv) quanto às metas, a moderna regulação se baseia na necessidade de busca e manutenção do equilíbrio dentro do sistema regulado ${ }^{115}$, o que traz a dificuldade do se equacionar os interesses privados dos diversos grupos conflitantes com as metas de interesse público a serem alcançadas, o

\footnotetext{
${ }^{112}$ O que foi devidamente acolhido no Brasil pela Constituição de 1988, cujo caput do artigo 174, que, diga-se, já consta com a redação atual desde o dia da promulgação do Texto Maior, determina: artigo 174, caput, que dispõe: "Como agente normativo e regulador da atividade econômica, o Estado exercerá, na forma da lei, as funções de fiscalização, incentivo e planejamento, sendo este determinante para o setor público e indicativo para o privado". (g.n.)

${ }_{113}$ O estado pós-moderno, 2009, p. 73.

${ }^{114}$ FLORIANO DE AZEVEDO MARQUES NETO, Agências reguladoras independentes..., cit., p. 31-34.

${ }^{115}$ Idem,, p. 33-34 e VitAl MOREIRA e FERNANDA MAÇÃs, Autoridades reguladoras..., cit., p. 13-14.
} 
torna o setor regulado frágil às intervenções externas que não sejam introduzidas por meio da ponderação e do equacionamento dos interesses.

Destaca BILAC PINTO ${ }^{116}$ que dentre as finalidades da regulação dos serviços públicos estão: (i) assegurar serviço adequado; (ii) fixar tarifas razoáveis; e (iii) garantir a estabilidade financeira do serviço concedido e regulado. Para assegurar tais finalidades, a regulação implica na integração de três poderes, de acordo com as considerações de MichEL GENTOT ${ }^{117}$ : (iii) o de editar regras, os regulamentos, sobre certas atividades que devem respeitar um equilíbrio entre os interesses das diversas forças sociais presentes, os direitos dos cidadãos e o interesse geral; (iii) o de assegurar a aplicação de tais regras; e (iii) reprimir as infrações. Somam-se a estes, conforme ensina Floriano de AzeVedo Marques $\mathrm{NeTO}^{118}$, o (iv) poder de outorga, pelo qual a agência emite atos concretos de licença, autorização ou outra medida de injunção para autorizar ou vetar o exercício de atividade regulada por particular, o que não deve ser feito na concessão de serviços público, hipótese em que o poder concedente deve ser a Administração central, com a finalidade de manter a imparcialidade do regulador; (v) poder de conciliação, pelo qual o ente regulador media conflitos e concilia interesses dentro do setor regulado, tais como os dos operadores, consumidores ou de agentes econômicos que se relacionam com o setor, a despeito de não explorarem diretamente a atividade setorial regulada, como ocorre nos setores de infraestrutura; e (vi) a prerrogativa de recomendação, pela qual o ente regulador deve (trata-se de dever-poder) encaminhar à Administração central informações que sejam relevantes para o planejamento e aprimoramento de políticas públicas.

Engloba, portanto, a regulação, uma série de atividades, que visam a adequar a atividade de interesse coletivo aos interesses da sociedade, além de garantir a universalização dos serviços públicos, sua prestação em padrões de qualidade, a sua continuidade e sua mutação para se adequar às constantes mudanças tecnológicas da sociedade. Assim, nesse quadro de retirada do Estado da prestação direta de serviços públicos e atividades econômicas, a regulação necessita de ser mais intensa do que

\footnotetext{
${ }^{116}$ Regulamentação..., cit., p. 102.

${ }^{117}$ Les autoritès administratives indépendants, $2^{\text {a }}$ ed., 1994, p. 41.

${ }^{118}$ Agências reguladoras..., cit., p. 60-61.
} 
aquela feita anteriormente ${ }^{119}$, quando o próprio ente estatal prestava e regulava a atividade $^{120}$.

Conforme ensina CALIXTO SAlOMÃo FILHO $^{121}$, a teoria da regulação pode "representar exatamente a contribuição mais útil de um Estado que decide retirar-se da intervenção econômica direta (através da prestação de uma gama bastante variada de serviços) para sua função de organizador das relações sociais e econômicas e que, por outro lado, reconhece ser, para tanto, o mero e passivo exercício de um poder de polícia sobre os mercados". Assim, a regulação "engloba toda forma de organização da atividade econômica através do Estado, seja a intervenção através da concessão de serviços públicos ou o exercício do poder de polícia", uma vez que "o Estado está ordenando ou regulando a atividade econômica tanto quando concede ao particular a concessão de serviços públicos e regula a sua utilização impondo preços, quantidades

119 Conforme Diogo de Figueiredo Moreira Neto, "Assim é que, com o declínio dos modelos de Mega-Estado referidos e, com eles, das formas de intervenção concorrencial e monopolística da economia, ou seja, com a devolução da execução das atividades econômicas aos entes da sociedade, evidenciou-se a necessidade de abandonar a ingênua presunção de que os serviços públicos estavam realmente sendo submetidos a regras e controles de interesse público e, com isso, de republicizar os controles sobre algumas delas, tanto sobre aquelas legalmente definidas como serviços públicos, como sobre outras mais, de relevante interesse geral, como, destacadamente, as capazes de oferecer riscos à segurança e à saúde públicas". (Mutações do direito administrativo, p. 198).

Segundo FloRiano DE AZEVEDo MARQUes Neto, "A explicação para esse fenômeno é simples. Aumenta a necessidade regulatória porque, deixando o Estado de ser ele próprio provedor do bem ou serviço de relevância social, tem ele que passar a exercer algum tipo de controle sobre essa atividade, sob pena de estar descurando de controlar a produção de uma utilidade dotada de essencialidade e relevância. (A nova regulação estatal e as agências independentes, in Carlos Ari Sundfeld (coord.), Direito Administrativo Econômico, p. 75).

Importante notar, que já na década de 40 do século passado, BILAC PINTO afirmava haver três formas de do Estado regular o serviço público: (i) a regulação puramente contratual; (ii) a regulação por meio de comissões (hoje chamadas de agências); e (iii) a regulação direta pelo Poder Público. Dentre estas formas, afirmava o autor que a mais eficiente era a realizada por comissões (agências), uma vez que a feita diretamente pelo Poder Público somente é aplicável ao regime das sociedades de economia mista e à propriedade pública. Com relação à regulação contratual, tal autor entendia ser ineficiente e, portanto, ter caído em descrédito. (Regulamentação efetiva..., cit., p. 34 e segs.).

De acordo com a lição de FRANCISCO CAMPOS, a regulação por contrato é insuficiente para a regulação efetiva, uma vez que, em síntese: (a) todas as obrigações do concessionário estão previamente previstas no instrumento contratual, o que não faria com que a empresa integrasse à prestação as novas tecnologias criadas pelas indústrias; (b) como o controle do Estado é apenas precontratual, inexiste a possibilidade de se exigir da concessionária a ampliação da prestação do serviço, preferindo esta prestá-lo apenas em locais de grande densidade populacional, que possam pagar por tarifas calculadas em graus máximos, não em mínimos; (c) sendo a tarifa de remuneração do concessionário fixada no contrato, esta terá embutido os riscos do negócio, que serão pagos pelos usuários, mesmo que os riscos não se verifiquem (Pareceres, p. 189-194, apud Bilac Pinto, Regulamentação..., cit., p. rodapé p. 36-37.)

${ }^{120}$ Nessa fase, a regulação era feita mais em favor e interesse do próprio ente regulado do que tendo em vista o interesse da coletividade. A esse respeito, Floriano de AZeVEdo Marques Neto, A nova regulamentação... cit., p. 8.

${ }^{121}$ Regulação da atividade econômica (princípios e fundamentos jurídicos), p. 20-21. 
produzidas etc. - como quando edita regras no exercício do poder de polícia administrativa".

Dentro de uma ordem econômica posta na Constituição Federal nos moldes do art. 170, parece-nos haver um norte a ser seguido pela atividade regulatória do Estado. Com isto queremos dizer que nos parece claro haver um norte, um ponto de chegada para o qual deve convergir a regulação estatal de atividades econômicas em suas diversas manifestações, o que interdita ao legislador e ao regulador a tomada de medidas que sejam contrárias a tais finalidades constitucionalmente asseguradas, típicas de um Estado de índole social.

Diante desta pluralidade de objetivos e de poderes, podemos afirmar, na linha de AleXAndre Santos de Aragão,

\begin{abstract}
"que a regulação estatal da economia é o conjunto de medidas administrativas, legislativas e convencionais, abstratas ou concretas, pelas quais o Estado, de maneira restritiva da atividade privada ou meramente indutiva, determina, controla ou influencia o comportamento dos agentes econômicos, evitando que lesem os interesses sociais definidos no marco da Constituição e orientando-os em direções socialmente desejáveis" 122 .
\end{abstract}

Resta afastada de tal conceito de regulação, conforme nos lembra o autor, a "atividade direta do Estado como produtor de bens ou serviços e como fomentador das atividades econômicas privadas, que, junto com a regulação, constituem espécie do gênero da intervenção do Estado na economia" ${ }^{123}$.

Diante dessa nova realidade, foi necessária a criação de entes independentes da Administração Direta e, portanto, não sujeitos ao controle hierárquico desta, dotados de intensa capacidade técnica, com a finalidade de regular a prestação dos serviços públicos pelos particulares, de modo a que os interesses legítimos dos diversos atores presentes na prestação do serviço público (concessionária, poder concedente e usuário) possam ser mais bem equacionados ${ }^{124}$.

${ }^{122}$ In J. J. Gomes Canotilho et alli, Comentários à Constituição do Brasil, 2014, p. 1835.

${ }^{123}$ Idem, ibidem.

${ }^{124}$ Conforme ensina CAIO TÁCITO, “A função das Agências Reguladoras - objeto de valiosa e abundante bibliografia nacional - mantém o adequado equilíbrio entre a política de privatização e a preservação do interesse público, harmonizando a liberdade com a adequação dos fins básicos da manutenção dos interesses da comunidade. A privatização transfere o serviço público à gestão privada. O poder público 
E tal modelo de regulação por meio de agências independentes possui total compatibilidade com o sistema jurídico brasileiro, uma vez que, conforme a assertiva de CARlos ARI SundFelD ${ }^{125}$, “A regulação é - isso, sim - característica de um certo modelo econômico, aquele em que o Estado não assume diretamente o exercício de atividade empresarial, mas intervém enfaticamente no mercado utilizando instrumentos de autoridade. Assim, a regulação não é própria de certa família jurídica, mas sim de opção de política econômica".

Ora, tendo o constituinte brasileiro optado por um modelo econômico de retirada do Estado da intervenção na economia para a intervenção sobre a economia, nada mais natural que a adoção do modelo de agências reguladoras independentes para a condução dos rumos da economia e da prestação das atividades aos particulares.

A legalidade, por sua vez, neste contexto sofre uma tripla mutação.

De um lado, conforme visto, a emergência dos entes de regulação da prestação de serviços implica na consolidação e solidificação da atividade normativa pela Administração, uma vez que as matérias de cunho técnico passam a predominar em detrimento das decisões de caráter meramente político. Assim, mais do que no período anterior, a necessidade de tomada rápida de decisões técnico-econômicas, implica na atribuição de poderes normativos a tais entes.

Com efeito, a tecnicidade cada vez mais complexa, aliada à necessidade de criar um ambiente seguro para os investimentos da iniciativa privada em setores estratégicos da economia, fez com que se tornasse imperativa a normatização de tais setores por entes especializados, afastados dos debates político-partidários, que marcam a Administração Direta. Conforme ensina Diogo DE FigueIREdo MoreIRA NeTO:

“Com efeito, essa competência normativa atribuída às agências reguladoras é a chave de uma desejada atuação célere e flexível para a solução, em abstrato e em concreto, de questões em que predomine a escolha técnica, distanciada e isolada

retém, contudo, a supervisão, sobre o exercício regular da atividade, em garantia os conselheiros e usuários, na preservação do interesse geral, que o Estado representa". (Agências reguladoras da administração, Revista de Direito Administrativo, no 221, 2000, p.5).

${ }^{125}$ Introdução às agências reguladoras, in (coord.)., Direito administrativo econômico, p. 23. 
das disputas partidarizadas e dos complexos debates congressuais em que preponderam as escolhas abstratas político-administrativa, que conformam a arena de ação dos parlamentos, e que depois se prolongam nas escolhas administrativas discricionárias, concretas e abstratas, que prevalecem na ação dos órgãos burocráticos da administração direta" ${ }^{\text {126 }}$.

De outro lado, nos países de tradição europeia continental, a Constituição passa a ter, um valor cada vez maior como instrumento de previsão de direitos aos cidadãos. $\mathrm{Na}$ realidade, o processo de fragmentação social levou, como visto, à perda da capacidade das leis terem o caráter de generalidade e abstração, passando a prever políticas pontuais e setoriais. Diante disso, os grupos sociais passaram a encontrar no texto constitucional o locus de generalidade e abstração antes detido pela lei, o que implica no inchamento da Constituição com direitos e deveres impostos ao Estado ${ }^{127}$.

Nesse contexto, os métodos de interpretação do direito passam a conferir efetividade normativa direta aos textos constitucionais, o que possui o efeito de permitir a ponderação direta de direitos a partir da Constituição. Para os estritos limites do presente trabalho, não nos interessam as causas que levaram a tal cenário de constitucionalização do direito. Interessa-nos a constatação de que, no atual cenário jurídico, a Constituição é vista como fonte de obrigações para o Estado, de tal forma que, além de observar a lei, deve ele observar, também, as normas constitucionais ${ }^{128}$.

\footnotetext{
${ }^{126}$ Mutações no direito administrativo, cit., p. 214.

${ }^{127}$ Conforme ensina ODETE MEDAUAR: "Quanto à inflação de normas, pode-se pensar que, ante esse quadro, a aspiração ao geral, impessoal e estável transferiu-se para a Constituição; isso ficou muito claro no período de elaboração da Constituição brasileira de 1988, em que transparecia a expectativa de estabilidade, segurança jurídica, efetividade dos preceitos que acolhesse. A Constituição passou a ter o papel de núcleo estável em meio à inflação e mutabilidade das normas, funcionando como um articulador dos textos dispersos e como constante memória dos valores primordiais do ordenamento. Disso oferece prova também a crescente importância adquirida pelo controle de constitucionalidade de leis e outros atos estatais, sobretudo em países que não tinham essa tradição; a criação e funcionamento das cortes constitucionais levaram à valorização, sobretudo na França, na Alemanha e na Espanha, dos princípios subjacentes a todo o ordenamento, previstos expressamente na Constituição ou extraídos dos preâmbulos e da caracterização do Estado como de direito. No Brasil também ocorre essa valorização". (O direito administrativo em evolução, cit., p. 106). Tal tendência é expressa e clara na Constituição Federal de 1988, que contempla os mais variados direitos de grupos tidos como antagônicos. Conforme aponta o percuciente trabalho de ANDRÉ ROSILHO, a elaboração de tal Constituição se deu com ampla participação popular, o que implicou na realização de 125 audiências públicas e 122 emendas populares ao projeto de texto constitucional em trâmite na Assembleia Nacional Constituinte, além da rejeição ao projeto elaborado pela "Comissão de Notáveis" presidida por Afonso Arinos, por não representar os anseios populares. Afinal, "A ideia era inverter a lógica das coisas: se, antes, a decisão vinha de "cima para baixo', agora, numa Democracia, teria que vir 'de baixo para cima'; o que se queria era ouvir o povo, que por tanto tempo deixara de ter voz. E, de fato, o povo teve voz". (A constituição de 1988 e suas políticas em quatro atos, in Carlos Ari Sundfeld e André Rosilho, Direito da regulação e políticas públicas, 2014, p. 22-24).

${ }^{128}$ De acordo com a lição de Luís ROBERTO BARROSO, "A ideia de constitucionalização do direito aqui explorada está associada a um efeito expansivo das normas constitucionais, cujo conteúdo material e
} 
Diante disso, as prestações devidas ao Estado para os cidadãos passam a ter embasamento não apenas na lei, mas também na Constituição, o que aumenta ainda mais a pressão sobre a Administração. Por mais que eventualmente alguma prestação estatal não tenha previsão em lei, mas possua previsão constitucional, a Administração pode ser compelida a fornecê-la, como ocorre, por exemplo, nos casos de prestação de medicamentos e serviços de saúde.

Assim, a legalidade administrativa passa a ser ampliada, uma vez que a Administração deve respeitar não apenas os preceitos legais, mas também as normas constitucionais, o que implica na quebra do paradigma da inércia administrativa quando inexiste previsão legal.

Em terceiro plano, a legalidade passa a ter uma lógica diversa daquela verificada em períodos anteriores. Passam a figurar na pauta de debates jurídicos a pressão social por "novos direitos", como direito à moradia, direito por um meio ambiente urbano saudável e equilibrado, o direito à previdência social, as questões relacionadas ao acidente de trabalho, os direitos das minorias etc., situação que já se desenhava no período anterior, mas que acabava sendo contida pela assunção pelo Estado de tais prestações.

No entanto, diversamente do que ocorreu no período anterior, o Estado não aumenta sua estrutura para o atendimento a tais contingências econômicas e sociais, mantendo-se como agente regulador das atividades econômicas, como indutor de comportamentos que venham a gerar os melhores resultados, e também não passa a atuar isoladamente na solução destes problemas, impondo tal ônus também à sociedade civil. Passa-se àquilo que é chamado de direito social ${ }^{129}$, com a intenção de evitar que as desigualdades sociais impliquem na desintegração do tecido social.

axiológico se irradia, com força normativa, por todo o sistema jurídico. Os valores, os fins públicos e os comportamentos contemplados nos princípios e regras da Constituição passam a condicionar a validade e o sentido de todas as normas do direito infraconstitucional" (A constitucionalização do direito e suas repercussões no âmbito administrativo, in Alexandre Santos de Aragão; Floriano de Azevedo Marques Neto. Direito Administrativo e Seus Novos Paradigmas, p. 32).

${ }^{129}$ JOSÉ EDUARDO FARIA, O direito na economia globalizada, cit., p. 269-280. 
Ora, sendo o direito de índole social composto de leis com finalidades promocionais, que, de um lado, "em vez de se cingirem apenas à definição das 'regras do jogo', são especialmente concebidas para modificar os resultados desse jogo, alterando implicitamente suas regras" ${ }^{130} \mathrm{e}$, de outro, serão aplicadas se e quando determinadas condições econômicas e políticas ocorrerem, sendo que, ainda que implementadas, as políticas - tidas como direitos subjetivos pelos grupos beneficiários - poderão ser alteradas ante a existência de cenário de contingência e de necessidade de atendimento a tantos outros interesses, não é difícil perceber que, em países que adotaram o sistema de unidade de jurisdição, como o Brasil, mais cedo ou mais tarde o Poder Judiciário seria provocado a controlar as decisões e omissões administrativas.

Vale notar que o próprio sistema jurídico, na atual configuração brasileira, acaba estimulando os grupos sociais a ingressarem em Juízo para a conquista de seus direitos. De um lado, a abertura da cláusula do art. 5, XXXV, da Constituição Federal, permite que toda lesão ou ameaça seja levada ao Judiciário. De outro, a função judicial é a única, em relação às demais, que está obrigada a decidir, em virtude da previsão do Código de Processo Civil da regra que veda o non liquet ${ }^{131}$. Assim, enquanto o Legislativo e o Executivo podem postergar a decisão para um momento menos conflituoso, o Judiciário é obrigado a decidir. Além disso, ao menos em tese e na configuração clássica, o Judiciário é exercido por agentes neutros politicamente, estando mais imune às pressões políticas que os demais Poderes.

É justamente nesse cenário que cresce a judicialização das políticas públicas e decisões não mais apenas jurídicas dos órgãos e entes da Administração. Com efeito, a implementação de políticas públicas é feita de acordo com o "cálculo do dissenso tolerável"132, ou seja, pela análise do quanto de dissenso é possível gerar em determinados grupos sociais para atendimento de dada política pública, sem gerar uma reação adversa de tais grupos. A partir do momento, no entanto, que o dissenso se torna intolerável, sem conseguir sucesso em suas reivindicações junto à Administração Pública, os grupos sociais desatendidos ou afetados pelas políticas públicas passam a

\footnotetext{
${ }^{130}$ JoSÉ EDUARDO FARIA, O direito na economia globalizada, cit., p. 275.

131 Trata-se da regra do artigo 126, que determina: "O juiz não se exime de sentenciar ou despachar alegando lacuna ou obscuridade da lei. No julgamento da lide caber-lhe-á aplicar as normas legais; não as havendo, recorrerá à analogia, aos costumes e aos princípios gerais de direito".

132 JOSÉ EDUARDO FARIA, O direito na economia globalizada, cit., p. 269-270.
} 
buscar fora do ambiente político a tutela de seus interesses, o que leva à colocação do Judiciário no centro de tal debate.

No entanto, o controle judicial a ser exercido sobre as decisões de implementação de políticas públicas não é o mesmo daquele feito nas duas fases anteriores o Estado, sob dois aspectos.

Em primeiro plano, tais conflitos levados a Juízo não são mais retributivos, mas sim distributivos, ou seja, trata-se da luta entre os diversos grupos para o acesso aos escassos recurso públicos e, além disso, à redistribuição das cargas sociais para a diminuição de desigualdades econômicas e sociais ${ }^{133}$.

Em segundo lugar, e como consequência do primeiro aspecto, há alteração no critério temporal de exercício do controle, em relação aos períodos anteriores do Estado, na medida em que nestes a função judicial tinha como aspecto temporal o momento posterior à realização do ato em julgamento, aplicando o direito ao fato consumado, ao passo que no atual cenário, o controle de tais políticas ocorre na perspectiva prospectiva, ou seja, tendo em vista os efeitos futuros. Valemo-nos mais uma vez da lição de JOSÉ EDUARDO FARIA ${ }^{134}$ :

\footnotetext{
"em vez de aplicar regras gerais, abstratas e impessoais a fatos anteriormente ocorridos entre partes formalmente iguais perante a lei, os magistrados são condicionados por uma visão prospectiva dos casos 'subjudice'; não se trata mais de julgar uma conduta tal como efetivamente ocorreu, porém como ela irá ser realizada; não se trata de responsabilizar as partes pelo que deixaram de fazer ou pelo que fizeram de certo ou errado nos termos da ordem jurídica vigente, mas de induzir uma delas a tomar uma dada iniciativa em face da sua 'hipersuficiência' econômica ou das suas 'obrigações sociais'; não se trata de penalizar e de obrigar a dar, entregar ou receber algo, porém de assegurar as condições de realizabilidade de determinadas pretensões da parte considerada materialmente débil".
}

Este segundo aspecto possui importância especial para o presente trabalho, no que se refere à aplicação da lei pelos Tribunais. Habituados a lidar com leis de redação fechada e de aplicação a situações predeterminadas, os magistrados se veem diante de leis que, ao instituírem programas e políticas, são de aplicabilidade condicionada a

\footnotetext{
${ }^{133}$ ARTHUR SANCHEZ BADIN, Controle judicial das políticas públicas, 2013, p. 16.

${ }^{134} \mathrm{O}$ direito na economia globalizada, cit., p. 275.
} 
fatores sociais, econômicos e políticos, o que implica na intensa mutabilidade das decisões judiciais. Ao invés de conceder segurança e previsibilidade, o direito social implica em insegurança e imprevisibilidade.

O constante recurso a cláusulas abertas, conceitos indeterminados e princípios implica na estipulação de "regras de julgamento" ${ }^{135}$, que serão interpretadas de acordo com o contexto da disputa, de modo que, em determinado caso, o direito à moradia poderá prevalecer sobre a preservação ambiental, sem que tal decisão possa ser aplicada a outro conflito semelhante, mas posto em outro contexto. A conflituosidade gerada na atual fase implica no balanceamento e na ponderação de todos os interesses envolvidos em determinada lide, o que faz as decisões judiciais se tornarem cada vez mais próximas da cláusula rebus sic stantibus, ou seja, a decisão judicial será determinada muito mais pelo contexto político, econômico e social, do que pelo texto expresso da lei, sendo certo que determinado precedente judicial poderá ser aplicado ou não de acordo com o contexto, não apenas com a invocação genérica da norma posta.

Não bastasse, o caráter aberto dos preceitos normativos e a intensa conflituosidade dos grupos sociais levam o Judiciário a, por vezes, ter que se substituir na posição da Administração Pública, notadamente ao conceder aos cidadãos prestações de cunho positivo que lhes foram negadas por aquela, do que são exemplos corriqueiros os casos de tratamento de saúde e de vagas em escolas públicas. Ainda que essas atuações do Judiciário não sejam diretamente voltadas a interferir na política pública setorial, elas acabam, ainda que de modo indireto, a influí-las, uma vez que o medicamento concedido em medida liminar a uma pessoa pode significar o cancelamento da aquisição de dezenas ou centenas de vacinas para tantas outras pessoas.

Tem-se, então, um conflito entre os próprios Poderes do Estado ${ }^{136}$, uma vez que a política elaborada pela Administração Pública poderá, em sede de ação judicial, ser

\footnotetext{
135 A respeito da utilização dessas "regras de julgamento", cf. JOSÉ EDUARDO FARIA, O direito na economia globalizada, cit., p. 276-278.

${ }^{136}$ Conforme exposto por CELSO FERNANDES CAMPILONGO, “Já se escreveu, com razão, que o próprio conflito jurídico, que no contexto do Estado liberal apontava para a litigiosidade interindividual e no Estado social acentuava a componente classista, em alguns casos (como o italiano), no final do século $\mathrm{XX}$, assumiu o perfil de um conflito constitucional. É essa a observação de Pasquale Pasquino: 'As partes do conflito não são, neste caso, aquelas habituais do cenário político: direita e esquerda, católicos e laicos,
} 
questionada e, a depender dos interesses envolvidos, das peculiaridades do caso e do cenário econômico, social e político, ser impactada pela decisão judicial.

Levados muito mais pelas circunstâncias institucionais e pela falha na atuação da Administração que, tomada pela falta de planejamento e de estratégias para solucionar os imensos problemas sociais, o Judiciário acaba sendo acionado para assegurar direitos daqueles que foram excluídos pela ação administrativa. Afinal, conforme aponta JosÉ RENATO NALINI ${ }^{137}$,

\begin{abstract}
A cena judicial é simbólica. Abstraída a lide interindividual, daquelas questões que envolvem apenas pessoas, o século XXI é pródigo em outra tipologia de demandas. Cada vez mais o cidadão é desenvolto para litigar contra o Estado, em suas inúmeras configurações. E o Judiciário é o único poder que tem condições de colocar o Estado em xeque. Em tese, o autor se encontra em pé de igualdade com o Estado-réu. Este, em juízo, não é o senhor onipotente, titular de soberania, inatingível e invulnerável. É alguém que poderá responder por seus atos ou por sua desídia.
\end{abstract}

É justamente nesse momento de uma maior atuação do Poder Judiciário frente às demais funções, notadamente a administrativa, que se insere o debate que será travado no presente trabalho. Afinal, num clima de intensa fragmentação social e de conflituosidade entre os diversos grupos antagônicos, no qual o Judiciário é constantemente provocado a se manifestar sobre os mais diversos problemas e situações de índole coletiva, cabe a reflexão a respeito dos limites da atividade judicial em tais tipos de conflitos.

No que se refere às agências reguladoras e seus atos normativos, tema específico do presente trabalho, a problemática que se coloca é que tais atos têm como principal finalidade estipular uma política regulatória, de acordo com as peculiaridades econômicas, sociais e técnicas do setor regulado, que formam aquilo que podemos chamar de racionalidade do setor regulado.

empresários e sindicatos e assim por diante. São, ao contrário, órgãos do próprio Estado; sujeitos que representam as nossas próprias instituições. A magistratura, de uma parte, o governo expressão da maioria parlamentar, de outra”. (Política..., cit., p. 41)

137 O Poder Judiciário na Constituição de 1988, in Ives Gandra da Silva Martins et alli, Tratado de Direito Constitucional, vol. 1, 2010, p. 981. 
Essa racionalidade se expressa sobretudo por meio do caráter procedimental que a regulação estatal possui, ou seja, os atos normativos regulatórios são expedidos de acordo com procedimentos nos quais há a intensa e ampla participação dos diversos interessados no setor regulado (consumidores, prestadores etc.).

Tais atos normativos são expressos por meio de Resoluções, Portarias ou outros veículos introdutores de normas gerais e abstratas que possuem por finalidade regrar aspectos do setor regulado. Tal tema será melhor desenvolvido no capítulo seguinte, dedicado à atividade normativa das agências reguladoras, mas desde logo é possível afirmar que os atos normativos regulatórios são expedidos dentro de uma lógica de análise pelo ente regulador da melhor solução para um caso concreto, conforme uma pluralidade de interesses conflitantes. A Administração, nesses casos, atua não apenas através da imposição de direitos e deveres de modo extroverso e unilateral, mas, também, através da composição de interesses dos diversos agentes envolvidos no setor regulado.

Diante disto, parece-nos que o controle judicial da atuação regulatória possui algumas peculiaridades que merecem uma atenção detida em tal assunto. Queremos com isto dizer que, por mais que o Judiciário possua hoje uma função primordial no que se refere à concretização de direitos, sendo demandado a intervir nos mais diversos conflitos sociais, a intervenção judicial nos conflitos que envolvam setores regulados demandam cautelas especiais.

Com efeito, ao contrário dos diversos atos normativos infralegais, que costumam ter uma racionalidade meramente jurídica, ou seja, na condição de executores da lei, trazendo os pormenores que esta deixou para regulamentação pelo Executivo, o ato normativo regulatório atende a uma racionalidade ao mesmo tempo jurídica, econômica, política e técnica, de tal forma que se trata de um ato jurídico que implementará uma dada política regulatória, de acordo com a racionalidade econômica do setor regulado e em atenção aos diversos interesses econômicos colidentes, na conformidade das técnicas possíveis de serem implementadas no setor.

Em breve síntese, pois tal tema será objeto do capítulo II, cada um desses elementos que integram a racionalidade complexa do ato normativo regulatório pode ser 
assim explicado: (i) sob o prisma jurídico, o ato normativo deverá se conformar à Lei que instituiu a agência e à Constituição Federal, além de guardar determinada lógica redacional interna e adequação com a razoabilidade e a proporcionalidade; (ii) do ponto de vista econômico, o ato normativo deverá levar em consideração a lógica econômica do setor, ou seja, a existência ou não de monopólios naturais, as falhas de mercado, a possibilidade ou não de concorrência na prestação dos serviços regulados, as fontes acessórias e principais de recursos para o custeamento do serviço etc; (iii) com relação ao prisma político, as agências possuem certa liberdade de escolha do momento de implementação de determinada política regulatória previamente fixada na respectiva Lei de criação. Dizemos certa liberdade, pois por vezes pode ser que o próprio sistema regulado, sua racionalidade ou mesmo os usuários exijam a adoção de determinada política, o que a tornará necessária por parte da agência; (iv) no que se refere ao aspecto técnico do ato normativo, ele implica na determinação de que a política regulatória seja implementada do modo tecnicamente mais adequado para o dado setor regulado, o que poderá sofrer limitações de ordem econômica.

Vale notar, que tais elementos que integram o ato normativo regulatório são analisados de acordo com o setor regulado, de tal forma que esta insularização setorial implica na possível diferenciação da racionalidade regulatória de setor para setor, de tal forma que aquilo que é considerado a melhor política regulatória para o setor de telecomunicações pode não o ser para o de distribuição de energia elétrica.

Tal característica implica em uma especificidade em relação ao debate em relação ao controle judicial das políticas públicas, uma vez que a política regulatória não se confunde com estas. Conforme aponta Floriano DE AZEVEDO MARQUES NETO ${ }^{138}$, as políticas públicas têm por objetivo o atendimento a um objetivo de interesse geral, conjugando tanto políticas de Estado, que estão postas na Constituição e nas leis, quanto políticas de governo, que se referem à orientação política que se pretende imprimir em determinado setor, sendo as políticas públicas definidas necessariamente de acordo com mediações políticas.

\footnotetext{
${ }^{138}$ Agências reguladoras..., cit., p. 85-87.
} 
No que se refere às políticas regulatórias, aponta o autor ${ }^{139}$ que elas se referem à implementação das políticas públicas setoriais, sendo o órgão regulador responsável por ponderar a intensidade, o momento e a necessidade da intervenção estatal no setor, bem como os instrumentos e meios que serão utilizados em tal intervenção. Assim,

\footnotetext{
"compete ao regulador introduzir no setor regulado as pautas de interesse geral contidas nas políticas públicas, atuando no sentido de que o sistema regulado absorva essas pautas, retomando o seu equilíbrio interno. Nesta perspectiva, a política regulatória envolverá a margem de liberdade do regulador em ponderar os interesses regulados e equilibrar os instrumentos disponíveis no sentido de intervir no sistema sem inviabilizar os seus pressupostos"
}

De nossa parte, entendemos que há mais uma diferença entre as políticas públicas e as políticas regulatórias. Enquanto aquelas são realizadas em áreas nas quais o próprio Estado é o prestador do serviço à população, tais como educação, saúde, moradia, entre outras, sendo tais ações financiadas por meio de recursos públicos, na maioria das vezes não objeto de contraprestação pelo particular, os setores regulados se caracterizam pela retirada do Estado do campo da prestação direta ou, no limite, à sua atuação por meio de empresas estatais, em regime de competição com os agentes privados, o que implica na necessidade de criar um ambiente atrativo para os investimentos privados nas respectivas áreas, o que torna mais complexo o alcance do equilíbrio setorial.

Com efeito, enquanto na política pública custeada mediante recursos públicos a sua implementação e expansão pode se dar mediante o aporte de mais dinheiro público, no setor regulado, a expansão deve ser feita respeitando-se as cláusulas econômicas dos contratos de concessão ou, em setores no quais a atividade é aberta à iniciativa privada apenas mediante outorga de autorização pelo Poder Público, de acordo com a necessidade de manutenção do equilíbrio econômico entre os interessados em tal setor.

E justamente essa necessidade de manutenção do equilíbrio dentro do setor regulado implica em um elemento de complexização do controle judicial de tal atividade estatal, na medida em que a verificação da validade/invalidade do ato não poderá se dar apenas com relação ao aspecto jurídico, uma vez que a verificação do

\footnotetext{
${ }^{139}$ Idem, p. 87-88.

${ }^{140}$ Idem, p. 88.
} 
caráter lícito/ilícito da norma deve ser feita, também, de acordo com as lógicas econômica, política e técnica.

Assim, o controle judicial da atividade normativa regulatória traz como elemento complicador a manutenção de um ambiente equilibrado, com a finalidade de não desestimular os investimentos privados e colocar em risco a continuidade e a qualidade da prestação regulada. É justamente sobre este tema que nos debruçaremos ao longo dos próximos capítulos.

\section{I.C - Conclusões Parciais}

Ao longo do presente capítulo pretendemos ter demonstrado que a configuração da separação de funções realizada por Montesquieu no século XVII é inaplicável ao atual contexto social, político e econômico. Se, quando da formação do pensamento da separação das funções do Estado o pensador francês definiu o Judiciário como a simples boca que pronuncia a lei, tal formulação chegou ao início do século XXI de forma oposta, ou seja, nesses conflitos distributivos de índole prospectiva, a lei acaba sendo aquilo que é constituído pelo juiz ao sopesar os diversos interesses em jogo no caso concreto ${ }^{141}$.

Impulsionado para o centro dos debates contemporâneos, nas suas mais variadas áreas, o Judiciários chega ao século XXI como o grande filtro de depuração dos conflitos cotidianos, uma vez que praticamente todas as questões da vida em sociedade, sejam elas de direitos individuais ou coletivos, acabam por encontrar, seja pela literalidade da redação legal, seja por alguma das formas de interpretação, alguma identidade no cenário jurídico, o que implica, no contexto de conflituosidade dilatada, na provocação do Estado-Juiz para dirimir controvérsias.

\footnotetext{
141 Importantes as considerações de JOSÉ RENATO NALINI: "É cada vez maior, portanto, a responsabilidade do juiz. Se ele já foi o mero aplicador da lei, que a boca pronunciadora das palavras da lei, o enfraquecimento do produto do Parlamento o converte em porta-voz do direito. Na divisão tradicional das funções estatais, o elaborador das regras era o poder de maior relevância. Restava ao juiz cumprir a lei na controvérsia e atuar como sancionador dos costumes. Hoje, a justiça já não é o braço armado do poder político. Ela continua a existir no mundo de valores em frangalhos. O crepúsculo axiológico vem a coincidir com a aurora da justiça. O justo já não coincide sempre com a lei. Em outras palavras, a lei não detém o monopólio do justo. A justiça é cada vez mais constitucional e revive como espaço de arbitragem permanente entre os interesses em conflito”. (O Poder Judiciário..., cit., p. 981).
} 
Da limitação ao controle judicial da Administração proclamada no século XIX, a evolução da separação de funções levou ao cenário no qual as próprias decisões tomadas pelos governantes no âmbito do debate político, por encontrarem correspondência direta ou indireta em algum texto legal, possam ao menos ser objeto de postulação junto ao Judiciário, ante a abertura da cláusula do art. $5^{\circ}, \mathrm{XXXV}$, da Constituição Federal.

Dentro deste quadro, a institucionalização de entes reguladores que possuem por finalidade a manutenção do equilíbrio intrassistêmico, exarando atos que se revestem de forma jurídica (atos administrativos infralegais), a despeito de dotados de complexidade que une aspectos econômicos, políticos, jurídicos e técnicos, implica, indubitavelmente, na possibilidade, ao menos em tese, da provocação do Judiciário para analisá-los.

Saber os limites de tal atuação judicial é justamente o que será visto nos capítulo III do presente estudo. 


\section{CAPÍTULO II - A ATIVIDADE NORMATIVA DAS AGÊNCIAS REGULADORAS}

No capítulo anterior, analisamos como a evolução social e econômica dos séculos XIX e XX implicaram na alteração da configuração da doutrina da separação de poderes tal qual concebida originariamente por Montesquieu. $\mathrm{O}$ intento foi $\mathrm{o}$ de demonstrar que a dinâmica da evolução do Estado Liberal para o Estado Social, com o crescente tecnicismo que domina as relações sociais implicou na necessidade de revisitação do dogma da separação de funções concebida como marco para a defesa da liberdade dos cidadãos frente ao Estado Absolutista.

Dois fenômenos foram apontados como marcas desta alteração de configuração. De um lado, a insuficiência do Legislativo como produtor de leis completas o suficiente para regrar todas as relações envolvendo a Administração Pública, o que levou esta a ser cada vez mais uma produtora de normas, ainda que tais normas sejam limitadas em seus âmbitos material e adjetivo pelas leis do Parlamento. De outro, a incorporação das demandas sociais por meio de estatutos jurídicos (leis, decretos, regulamentos, atos administrativos concretos etc.), somada ao sistema de unidade de jurisdição e à cláusula de sua inafastabilidade (art. 5 $5^{\circ} \mathrm{XXXV}, \mathrm{CF}$ ), implicaram na colocação do Judiciário no centro dos debates políticos, econômicos e sociais que são corporificados pelas normas jurídicas. No presente capítulo, trataremos do primeiro efeito acima destacado.

\section{II.A - A Natureza Jurídica da Competência Normativa: A Delegação Legislativa}

O primeiro aspecto a ser analisado no que se refere à competência ${ }^{142}$ normativa dos entes reguladores é a que diz respeito à sua natureza jurídica, ou seja, qual o instituto jurídico que justifica a atribuição de competências normativas pelos entes reguladores.

\footnotetext{
${ }^{142}$ Preferimos a utilização do termo competência normativa a poder normativo, na medida em que aquela remete à ideia de competência para o exercício da função pública, de tal forma que os poderes manejados pelo regulador o são dentro do dever de utilizá-los na perseguição do interesse público. A esse respeito, cf. Celso Antônio Bandeira de Mello, Curso..., cit., p. 146-150.
} 
De acordo com EROS RoBERTO GRAU, a conferência de poderes normativos a entidades administrativas corresponde à capacidade normativa de conjuntura, "via pela qual se pretende conferir resposta à exigência de produção imediata de textos normativos, que as flutuações da conjuntura econômica estão, a todo o tempo, a impor" ${ }^{143}$. Tal capacidade normativa não decorre de delegação legislativa, na medida em que tratar-se de função regulamentar, que abrange tanto a função legislativa, quanto a função normativa, esta última detida pela Administração e pelo Judiciário ${ }^{144}$.

LEILA CUÉLlAR, em importante obra a respeito do tema ${ }^{145}$, afirma que o poder normativo das agências reguladoras não decorre de delegação legislativa, tendo em vista que (i) esta técnica é vedada no ordenamento constitucional brasileiro; (ii) a delegação por ser sempre precária e excepcional, poderia ser cassada pelo Legislativo a qualquer momento, com a extinção da agência ou frustração de sua natureza jurídica, e (iii) no direito brasileiro inexiste qualquer forma de controle político sobre os atos regulamentares das agências, o que implica na impossibilidade de controle pari passu de tal competência delegada. Diante disto, defende a autora que o poder normativo das agências reguladoras decorre de um poder regulamentar autônomo, possível no Brasil ante a existência de limites à edição de regulamentos autônomos.

Outros autores ${ }^{146}$ sustentam que a competência normativa das agências decorreria do fenômeno da deslegalização ou delegificação, que consiste na "adoção, pelo próprio legislador, de uma política legislativa pela qual transfere a uma outra sede normativa a regulação de determinada matéria" ${ }^{147}$. Tal corrente doutrinária defende a técnica da delegificação como forma de evitar a delegação legislativa, que seria vedada pelo artigo $2^{\circ}$ da Constituição Federal, com a concessão de uma autorização pelo

\footnotetext{
${ }^{143} \mathrm{O}$ direito posto e o direito pressuposto, cit., p. 232.

144 Op. cit., p. 241 e segs.

145 As agências reguladoras e seu poder normativo, 2001, p. 107 e segs.

${ }^{146}$ Nesse sentido, cf. SÉRGIO GUERRA, Discricionariedade e reflexividade: uma nova teoria sobre as escolhas administrativas, 2008, p. 214 e segs.; DiOGO DE FIGUEIREDO MOREIRA NeTO, Direito regulatório, 2003, p. 170 e segs.; e MARCOS JURUENA VILLELA SOUTO, Direito administrativo regulatório, $2^{\mathrm{a}}$ ed., 2005, p. 49 e segs.

147 AlEXANDRE SANTOS DE ARAGÃO, Agências reguladoras e a evolução do direito administrativo econômico, $2^{\text {a }}$ ed., 2003, p. 423.
} 
legislador para que "entes descentralizados do poder público possam estruturar a 'moldura normativa', o marco regulatório de determinado subsistema especializado"148.

De nossa parte, no entanto, entendemos que a melhor sustentação para a existência de competência normativa pelas agências reguladoras é a delegação legislativa, o que demanda um aprofundamento do tema.

No que se refere à competência normativa da Administração Pública, a doutrina publicista brasileira é fortemente influenciada pela corrente que CARLOS ARI SUNDFELD chama de monista ${ }^{149}$, denominação decorrente do fato de enxergar na atividade administrativa a de mera execução de lei, de tal forma que "teria de ser limitada à simples concretização de deliberações legislativas anteriores, não podendo ser juridicamente criativa" ${ }^{150}$.

Baseada em uma interpretação literal da separação de poderes cunhada por Montesquieu, tal doutrina sustenta, em síntese, que o ato de legislar é indelegável e, em decorrência disto, à Administração Pública, ao editar um regulamento, somente restaria a mera reprodução e estipulação de procedimentos para a concretização dos comandos legais. Afinal, como faz questão de ressaltar tal linha doutrinária, os decretos e demais regulamentos existem para possibilitar a "fiel execução" da lei.

Talvez o maior expoente de tal corrente seja CELSO ANTÔNIO BANDEIRA DE MELlo, para quem somente por meio de lei se pode criar direitos e obrigações, de tal forma que "restrição alguma à liberdade ou à propriedade pode ser imposta se não estiver previamente delineada, configurada e estabelecida em alguma lei. E só para cumprir dispositivos legais é que o Executivo pode expedir decretos e regulamentos"151.

Nesta linha, por considerar que os regulamentos são meios apenas de pormenorizar os comandos legais, sem qualquer possibilidade de inovação no ordenamento - por serem os regulamentos formas de permitir a fiel execução da lei -, entende o autor que a competência legislativa é indelegável ao Executivo, como

\footnotetext{
148 SÉrgio GuERrA, Discricionariedade..., cit., p. 218-219.

${ }_{149}$ Administrar é criar?, in ___ Direito Administrativo para Céticos, $2^{\text {a }}$ ed., 2014, p. 231 e segs.

${ }^{150}$ Carlos Ari Sundfeld, op. cit., p. 233.

${ }^{151}$ Curso de direito administrativo, $30^{\text {a }}$ Ed., 2013, p. 353, com destaque no original.
} 
decorrência do art. $2^{\circ}$ da Constituição Federal ${ }^{152}$, de tal forma que o descumprimento de tal regra implicaria em "procedimento abusivo, inconstitucional e escandaloso"153. Traz, então, o autor, em duas passagens célebres e que bem demonstram o cerne do pensamento de tal corrente doutrinária, as situações que demonstrariam a ocorrência da delegação legislativa. Afirma:

\begin{abstract}
"Há inovação proibida sempre que seja impossível afirmar-se que aquele específico direito, dever, obrigação, limitação ou restrição já estavam estatuídos e identificados na lei regulamentada. Ou, reversamente: há inovação proibida quando se possa afirmar que aquele específico direito, dever obrigação, limitação ou restrição incidente sobre alguém não estavam já estatuídos e identificados na lei regulamentada. A identificação não necessita ser absoluta, mas deve ser suficiente para que se reconheçam as condições básicas de sua existência em vista de seu pressupostos, estabelecidos na lei e nas finalidades que ela protege ${ }^{, 154}$.

"Considera-se que há delegação disfarçada e inconstitucional, efetuada fora do procedimento regular, toda vez que a lei remete ao Executivo a criação das regras que configuram o direito ou que geram a obrigação, o dever ou a restrição à liberdade. Isto sucede quando fica definido ao regulamento definir por si mesmo as condições ou requisitos necessários ao nascimento do direito material ou ao nascimento da obrigação, dever ou restrição. Ocorre, mais evidentemente, quando a lei faculta ao regulamento determinar obrigações, deveres, limitações ou restrições que já não estejam previamente definidos e estabelecidos na própria lei. Em suma: quando se faculta ao regulamento inovar inicialmente na ordem jurídica. E inovar quer dizer introduzir algo cuja preexistência não se pode conclusivamente deduzir da lei regulamentada" ${ }^{, 155}$.
\end{abstract}

Assim, para tal corrente doutrinária, os regulamentos serviriam apenas para indicar de modo geral para toda a Administração o modus operandi para a aquisição de direitos e constituição de obrigações já previamente disciplinados em lei e trazer outros pormenores necessário à fiel execução da norma expedida pelo Legislativo. Tais autores, ao que parece adotam a mesma concepção do legislador que inspirou JosÉ ANTÔNIO PIMENTA BUENO, em 1857, a afirmar que:

“O poder legislativo é a mais alta expressão da soberania nacional; salvo os principios constitucionaes do Estado, os da moral e justiça natural, que elle deve sempre respeitar é a sua omnipotencia politica. É quem crea o direito, a obrigação e as penas, quem regula os outros poderes e os cidadãos, quem decreta as normas que devem reger a sociedade, em summa, é quem faz, interpreta e desfaz a lei.

\footnotetext{
152 Op. cit., p. 361.

${ }^{153}$ Op. cit., p. 363.

154 Op. cit., p. 359, com destaques no original.

155 Op. cit., p. 362-363, com destaques nos original.
} 
Quanto é grande a sua missão! Tem em suas mãos todos os elementos sociaes; dispõe, combina, coordena, determina, dá e não recebe preceitos. E' como que o credor que communica a vida, imprime sua sabedoria, dirige as forças e movimentos sociaes, todas as relações e interesses do Estado e dos individuos" 156 .

No entanto, com o devido respeito dos adeptos de tal corrente, entendemos que os tempos mudaram, as necessidades sociais se alteraram e, em tal conjuntura, não verificamos qualquer inconstitucionalidade ou escândalo na prática da delegação legislativa.

Em primeiro lugar, não nos parece que a técnica de delegação legislativa esteja vedada pelo Texto Constitucional. Diversamente da Constituição de 1946, cujo artigo $36, \S 2^{\circ}$, expressamente vedava tal possibilidade, ao afirmar que "É vedado a qualquer dos Poderes delegar atribuições”, a Carta de 1988 não trouxe tal restrição, de tal forma que não pode intérprete pretender encontrar princípios restritivos ao poder normativo da Administração onde eles não existem.

Com efeito, trouxe a Constituição expressamente a possibilidade de delegação legislativa, uma vez que concedeu ao Congresso Nacional a competência para "sustar atos normativos do Poder Executivo, que exorbitem do poder regulamentar, ou dos limites da delegação legislativa", conforme o artigo 49, inciso $\mathrm{V}$, de tal modo que o poder normativo poderá ser exercido pelo Poder Executivo, o que abrange as agências reguladoras ${ }^{157}$, uma vez que o este é mais amplo que apenas o Presidente da República, a teor do art. 76.

Vale notar, neste aspecto, que não nos parece que o artigo 25 do Ato das Disposições Constitucionais Transitórias - $\mathrm{ADCT}^{158}$ - represente impossibilidade para a

\footnotetext{
${ }^{156}$ Direito publico brazileiro e analyse da Constituição do Império, $1^{\mathrm{a}}$ parte, 1857, p. 47, grafia do original.

${ }^{157}$ A esse respeito, Floriano DE AZEVEdo MARQues NeTO, em dois trabalhos: Agências...cit., p. 108109; e Princípios da proporcionalidade e da legalidade na regulação estatal, Revista de Direito Administrativo, $n^{\circ} 232$, p. 368-397, especificamente, p. 372-374. Na mesma linha, ARY CASAGRANDE FILHO, Estado regulador e controle judicial, p. 103-104. Também parece ser o entendimento de AleXANDre DE Moraes, Agências reguladoras, in____ (org.), Agências Reguladoras, cit..., p. 17. 158 “Art. 25. Ficam revogados, a partir de cento e oitenta dias da promulgação da Constituição, sujeito este prazo a prorrogação por lei, todos os dispositivos legais que atribuam ou deleguem a órgão do Poder Executivo competência assinalada pela Constituição ao Congresso Nacional, especialmente no que tange a:

I - ação normativa;

II - alocação ou transferência de recursos de qualquer espécie.
} 
delegação legislativa, pois tal norma determina a revogação de atos editados pelo Executivo em substituição à competência do Congresso Nacional o que, no âmbito legislativo, parece-nos representar atos normativos editados sem qualquer standard em regra legal, ou seja, inovações primárias no ordenamento por meio de atos do Executivo, em manifestação de renúncia do Legislativo de exercer sua competência constitucional $^{159}$, o que era muito comum no regime constitucional anterior ${ }^{160}$.

No caso das agências reguladoras, a situação é totalmente diversa daquela objetivada pelo art. 25 do ADCT, pois as leis criadoras de tais entes previamente fixam os standards para a edição de atos normativos, de tal forma que não se trata de inovação primária no ordenamento jurídico, mas sim de normas secundárias expedidas pelas agências.

A grande questão a ser enfrentada em tal temática se refere aos limites de tal delegação legislativa, ou seja, quais as vedações impostas pela própria Constituição à possibilidade do Congresso delegar ao Executivo o tratamento pormenorizado de dadas matérias. Assim, na linha de TÉRCIO SAMPAIO FERRAZ JÚNIOR, é necessário verificar qual o "âmago intransferível dessa competência política" legislativa -, ou seja, até que ponto é possível que o Legislativo transfira ao Executivo a pormenorização de determinados segmentos sociais e econômicos. Afinal, conforme pontifica SÉRgio VARElla Bruna, "é, pois, chegada a hora de deixarmos de debater sobre a existência ou não de regulamentos autorizados (ou por delegação), para

$\S 1^{\circ}$ - Os decretos-lei em tramitação no Congresso Nacional e por este não apreciados até a promulgação da Constituição terão seus efeitos regulados da seguinte forma:

I - se editados até 2 de setembro de 1988, serão apreciados pelo Congresso Nacional no prazo de até cento e oitenta dias a contar da promulgação da Constituição, não computado o recesso parlamentar;

II - decorrido o prazo definido no inciso anterior, e não havendo apreciação, os decretos-lei alí mencionados serão considerados rejeitados;

III - nas hipóteses definidas nos incisos I e II, terão plena validade os atos praticados na vigência dos respectivos decretos-lei, podendo o Congresso Nacional, se necessário, legislar sobre os efeitos deles remanescentes.

$\S 2^{\circ}$ - Os decretos-lei editados entre 3 de setembro de 1988 e a promulgação da Constituição serão convertidos, nesta data, em medidas provisórias, aplicando-se-lhes as regras estabelecidas no art. 62, parágrafo único".

159 TÉRCIO SAMPAIO FERRAZ JÚNIOR, Agências reguladoras..., cit., p. 148.

${ }^{160}$ LUÍS ROBERTO BARROSO, Princípio da legalidade - Delegações legislativas - Poder regulamentar Repartição constitucional das competências legislativas. Boletim de Direito Administrativo, jan. 1997, p. $20-21$.

${ }^{161}$ Agências reguladoras: legalidade e constitucionalidade. Revista Tributária e de Finanças Públicas, $\mathrm{n}^{\mathrm{o}} 35,2000$, p. 149. 
voltarmos nossas preocupações aos métodos de controle dessa modalidade de poder normativo" $" 162$.

Uma leitura atenta da Constituição permite verificar que um primeiro limite reside nas matérias sobre as quais incide a reserva de lei, ou seja, as matérias nas quais o constituinte expressamente determinou que somente por lei podem ser estipuladas as hipóteses de incidência normativa. Tal ocorre, por exemplo, com o direito tributário (art. 150, inciso I, da CF) e com a definição de crime (art. 5, XXXIX, CF). Assim, as matérias referentes à exigibilidade e majoração de tributo e à definição de crimes estão sujeitas única e exclusivamente ao âmbito de definição da lei ${ }^{163}$.

Trata-se, aqui, daquilo que TERCIO SAMPAIO FERRAZ JÚNIOR chama de função de bloqueio do princípio da legalidade, caracterizado pela colocação da lei enquanto meio/condição (fundamento autorizador da atividade) e fim (limite da atividade), de tal forma que a lei "dá ao administrador a equação completa da sua ação: ela concede ao agente competência, isto é, poder de praticar aqueles atos ou de produzir as condições para que tenham lugar aqueles efeitos jurídico que forem postulados pelas necessidades do serviço considerado, necessidades que, porque previstas pelo legislador, são as únicas que podem determinar o agente" ${ }^{164}$. Em tal relação de bloqueio, a validade da norma se dá de forma condicional, ou seja, uma lei, de hierarquia superior condiciona a validade da norma de hierarquia inferior, na medida em que preestabelece o modo de sua edição. Assim, por exemplo, "uma norma constitucional que impõe uma vedação (proibição de instituir tributo que não seja uniforme) valida normas legais que estatuam tributações se respeitada a vedação, independente de se os fins (provimentos de recursos adequados às necessidades) estão ou não sendo alcançados" ${ }^{165}$. A lei, aqui, é uma estrutura condicional.

No entanto, ao contrário do quanto os doutrinadores da corrente monista sustentam, há outra função atribuída à legalidade, qual seja, a função de legitimação, que enxerga tal princípio como um instrumento de exercício da atividade administrativa, na medida em que a lei não é uma estrutura condicional, mas sim uma estrutura

\footnotetext{
${ }^{162}$ Agências reguladoras: poder normativo, consulta pública, revisão judicial, 2003, p. 94.

${ }^{163}$ Nesse sentido, cf. TÉRCIO SAMPAIO FERRAZ JÚNIOR, Agências reguladoras..., cit., p. 149-150.

${ }^{164}$ Agências reguladoras..., cit., p. 153.

165 Idem, ibidem.
} 
finalística. Em tal estrutura finalística, uma norma validará a de hierarquia inferior, na medida em que estabelecer as finalidades que deverá alcançar, remetendo a análise desta à verificação da razoabilidade e proporcionalidade de suas determinações. Por fundamentais, transcrevemos as palavras de TERCIO SAMPAIO FERRAZ JÚNIOR ${ }^{166}$ :

\begin{abstract}
"Já uma norma valida outra, finalisticamente, se preestabelece fins que devam ser alcançados, devendo ser encontrados os meios adequados. Neste caso, a validade da norma subseqüente localiza-se na solidariedade entre fins e meios, donde a questão da validade levantar problemas de proporcionalidade, razoabilidade, adequação etc. Por exemplo, é o caso de uma norma constitucional que preestabeleça o regime legal para concessões e permissões e nele o respeito aos direitos dos usuários, política tarifária e obrigação de manter o serviço adequado. Neste caso a validade constitucional da norma legal exige respeito à solidariedade de meios e fins".
\end{abstract}

É justamente em virtude dessa matriz finalística que surge a possibilidade - e mesmo o dever - de se delegar à Administração Pública a possibilidade de editar atos normativos que permitem um regramento óptimo do setor regulado, tarefa que não pode ser alcançada pelo legislador.

Assim, de acordo com a própria Constituição, o Legislativo pode delegar ao Executivo - leia-se Administração Pública - o regramento pormenorizado de determinado seguimento social e econômico, salvo no caso daquelas matérias submetidas à legalidade estrita nos termos constitucionais, ou seja, dependentes de lei para a especificação dos seus aspectos de incidência.

Nessa linha, aponta VITOR RHEIN SCHIRATO que somente seria ilegítima a delegação legislativa se houvesse a "abdicação pelo Poder Legislativo de sua função precípua (legislar) e de acúmulo pelo Poder Executivo de duas funções essenciais do Estado (editar e executar as leis)"167, o que não se verifica no caso das agências reguladoras, tendo em vista que é a Lei que concede e delimita a competência normativa de tais entes.

\footnotetext{
166 Idem, ibidem.

167 As agências reguladoras independentes e alguns elementos da Teoria Geral do Estado, in Alexandre Santos de Aragão e Floriano de Azevedo Marques Neto (Coord.). Direito Administrativo e Seus Novos Paradigmas, 2008, p. 512-513.
} 
Vale notar que não estamos aqui a afirmar que as agências reguladoras, ao menos no Brasil, possuem competência para a edição de regulamentos autônomos, assim entendidos como aqueles que podem inovar originariamente na ordem jurídica sem base em lei, o que remete à noção de haver aquilo que os franceses chamas de domaine du réglement ${ }^{168}$, ou mesmo a possibilidade do Executivo normatizar situações não tratadas pelo Legislativo, na medida em que "[N]ão é possível admitir que a omissão do Legislativo resultaria na admissão para atuação do ilimitada do Executivo. A geração de direitos, deveres, diferenciações entre os sujeitos e assim por diante depende da intervenção dos representantes do povo" ${ }^{169}$.

Em nosso sentir, o princípio da legalidade ainda é central no direito administrativo, o que implica que a competência regulamentar advenha de uma Lei aprovada pelo Legislativo, de tal forma que é ela que determinará os parâmetros a serem seguidos na edição do regulamento. Nesse passo é a lição de FLORIANO DE AZEVEDO MARQUES NETO ${ }^{170}$ :

\begin{abstract}
"Estou convicto de que não se põe possível ao Executivo avocar competências legiferantes, a serem exercidas por meio de regulamento, sob o argumento ou de inércia do Poder Legislativo ou de conveniência de normatização mais célere ou especializada. Porém, não tenho a mesma convicção para afirmar ser defeso ao próprio Poder Legislativo, deliberar por deslegalizar um determinado setor da vida econômica ou social, desde que inexistente vedação constitucional expressa para fazê-lo (v.g., nas matérias estritamente reservadas à lei, como por exemplo o direito penal ou matéria tributária - princípio da legalidade estrita). E não tenho tal convicção por entender que o conceito de lei em torno do qual se constrói a locução constitucional do princípio da legalidade (cf. artigo $5^{\circ}$, II, da Constituição Federal) admite uma intelecção ampla, não restritiva à lei em sentido formal".
\end{abstract}

Não se trata aqui, então, de admitir que a Administração possa editar regulamento que inove totalmente na ordem jurídica, sem qualquer lastro em lei ou com base em fundamento diretamente extraível da Constituição, uma vez que o Executivo no

\footnotetext{
${ }^{168}$ Tal distinção entre o domaine de la loi e o domain du réglement aparece na França por conta da Constituição de 1958 que, em seu artigo 34, dispõe a respeito das matérias que são afetas ao legislador e estabelece, no artigo 37, que as demais matérias diversas daquelas reservadas ao domínio da lei possuem um caráter regulamentar, sendo, portanto, de competência do regulamento. Cf. RENÉ CHAPUS, Droit administratif général, tome 1, 15 ed., 2001, p. 67-73.

${ }^{169}$ MARÇAL JUSTEN FILHO, O direito das agências reguladoras independentes, 2002, p. 506.

170 Princípios da proporcionalidade e da legalidade na regulação estatal. Revista de Direito
} Administrativo, n $^{\circ} 232$, p. 372. 
Brasil não possui tais prerrogativas ${ }^{171}$. O que defendemos é a inexistência de óbice a que a própria Lei, nas hipóteses que não se constituam em matérias postas sob a sua reserva, delegue à Administração Pública a possibilidade de regrar determinada matéria, o que é feito nos exatos termos e limites da Lei. Assim, entendemos plenamente possível que ocorra a "intencional, consciente e voluntária transferência pelo Legislativo em favor do Executivo da competência normativa para disciplinar certa matéria" ${ }^{172}$.

Em segundo lugar, o exercício do direito administrativo brasileiro jamais rejeitou a possibilidade de delegação legislativa, advinda das próprias necessidades práticas da Administração Pública, conforme uma breve incursão histórica é capaz de demonstrar, sendo fruto de verdadeira mutação constitucional de tal matéria.

A vedação às delegações legislativas, como bem aponta CARLOS ROBERTO SIQUEIRA CASTRO ${ }^{173}$, teve por finalidade evitar que se reinstaurasse no Brasil os abusos ditatoriais praticados durante o Estado Novo varguista, que teve como traços marcantes o recesso congressual e a centralização da função normativa no Executivo. Diante disto, a Constituição de 1946 caminhou para o outro extremo, vedando qualquer possibilidade de delegação legislativa, em descompasso com a tendência que ganhava força nos países desenvolvidos da mesma época, "deixando os governos constituídos sob a sua égide muitas vezes sem instrumentos eficazes de regulação dos múltiplos e complexos aspectos da vida social na segunda metade do século XX, que, em contraste, exigiam do Estado atuação pronta e decisiva para o enfrentamento das crises de toda ordem" ${ }^{174}$.

Porém tanto juristas de escol quanto a jurisprudência do Supremo Tribunal Federal jamais deixaram de apontar para a inoperância da cláusula da indelegabilidade, sendo que as necessidades práticas de efetivação da atuação da Administração na impossibilidade de aplicação prática de tal mandamento constitucional. Basicamente, a contestação realizada era de índole pragmática, na medida em que "O ponto de contestação era a profundidade da limitação ao exercício da delegação legislativa, que poderia tolher o dinamismo da produção normativa necessária à consecução de

\footnotetext{
${ }^{171}$ MARÇAL JUSTEN FILHO, O direito das agências reguladoras independentes, cit., p. 504 e segs.

${ }^{172}$ MARÇAL JUSTEN FILHO, O direito das agências reguladoras independentes, cit., p. 511.

${ }^{173} \mathrm{O}$ devido processo legal e os princípios da razoabilidade e da proporcionalidade, $4^{\mathrm{a}}$ ed., 2006, p. 112.

${ }^{174}$ Idem, ibidem.
} 
finalidades públicas, notadamente a prestação de serviços públicos. A preocupação, portanto, era com a governabilidade, incapaz de ser alcançada com um sistema rígido de produção normativa" ${ }^{175}$.

Na realidade, conforme bem ilustram as lições de administrativistas brasileiros contemporâneos à Constituição de 1946, a prática do exercício da função administrativa levou à aceitação de tal tendência. Afinal, "Regulamentar não é sòmente reproduzir a lei, mas ampliá-la e completá-la, segundo o seu espírito e o seu conteúdo, sobretudo nos aspectos que a própria lei, expressa ou implicitamente, outorga à esfera regulamentar" ${ }^{\prime 176}$.

De acordo com CAIO TÁCITO ${ }^{177}$, a atribuição de maiores competências legislativas à Administração é fenômeno que decorre da realidade, sendo observável tanto em países nos quais há a omissão da Constituição a respeito da possibilidade de delegação de poderes, como no caso dos Estados Unidos da América, quanto nos países nos quais há a vedação constitucional a tal prática, o que ocorria no Brasil e foi verificado na Constituição francesa de 1934.

\footnotetext{
175 Juliana Bonacorsi de Palma, Atividade normativa da Administração Pública. Estudo do processo administrativo normativo, 2014, p. 60-61.

${ }^{176}$ CAIO TÁCITO, As delegações legislativas e o poder regulamentar. Temas de Direito Público, $1^{\circ}$ vol., 1997, p. 510. Artigo originalmente publicado na Revista de Direito Administrativo, $\mathrm{n}^{\circ}$ 34, de 1953.

${ }^{177}$ Interpretação da norma administrativa. Métodos. Analogia. Eqüidade. Temas de Direito Público, $1^{\circ}$ vol., 1997, p. 499-500. Texto escrito originalmente em 1960. Em passagem emblemática e que bem descreve o contexto e as razões da maior participação da Administração na produção normativa, afirma o autor: "Fenômeno típico da expansão das atribuições administrativas do Estado é, de outra parte, o progressivo deslocamento da capacidade de determinação normativa, do âmbito dos Parlamentos para os órgãos do Poder Executivo. As delegações legislativas típicas ou dissimuladas são uma constante do direito positivo dos tempos modernos. No silêncio do texto constitucional (como nos Estados Unidos), ou mesmo nos caso de formal interdição (como na atual Constituição e na de 1934, ou na Constituição francêsa de 1946), a fôrça da realidade constitucional impõe a transferência para as mãos do Executivo de parte substancial da função legislativa. A Constituição italiana de 1947, admitindo expressamente a delegação legislativa, ou a Constituição francêsa de 1948, delimitando a matéria privativa da lei e determinando o caráter regulamentar de todo o campo remanescente, ou, ainda, o direito costumeiro inglês ampliando, cada vez mais, o rule making power, a cargo do Poder Executivo, são exemplos significativos da acentuada tendência de deslocar para o Poder Administrativo (encarnado nos órgãos executivos, segundo a expressão tão ao gôsto dos autores norte americanos), em detrimento do poder político dos Congressos, não sòmente a atribuição de realizar o direito, mas, igualmente, a de instituir as normas necessárias às suas finalidades. $\mathrm{O}$ poder regulamentar assume, em conseqüência, um papel substancial na criação do direito positivo, em matéria administrativa". (Op. cit., p. 499. A despeito de a grafia se referir à Constituição de francesa de 1948, cremos que o autor quis se referir à de 1958, haja vista (i) que inexistiu na França Carta Constitucional em 1948 e (ii) foi na Constituição de 1958 que ficou assentada a distinção entre o domaine de la loi e o domain du réglement, conforme nota 13 acima).
} 
Diante de tal realidade, afirma o autor que o regulamento de execução cede espaço gradativamente ao regulamento autônomo ou ao regulamento delegado, na medida em que a regra constitucional pela qual o poder regulamentar deve ser exercido para a execução das leis deve ser entendida como execução da ordem jurídica, o que inclui o "conjunto de ditames e princípios oriundos das leis e da Constituição" ${ }^{178}$. Não nega, entretanto, tal autor, que tais atos devam ser limitados e restringidos pela lei, sendo categorias secundárias de atos normativos.

Em texto publicado em 1986, ou seja, na vigência da Constituição de 1967, com a redação determinada pela Emenda Constitucional n ${ }^{\circ}$ 01/1969, CAIO TÁCITO ${ }^{179}$ se debruçou a respeito do esgotamento da função regulamentar da Administração nos regulamentos editados pelo Presidente da República. À época, o artigo 81, inciso III, de tal Carta atribuía privativamente ao Chefe do Executivo a competência para "sancionar, promulgar e fazer publicar as leis, expedir decretos e regulamentos para a sua fiel execução", texto de teor idêntico ao do art. 84, IV, da Constituição de $1988^{180}$.

Ao analisar tal temática, de acordo com larga reprodução dos ensinamentos dos mais abalizados publicistas nacionais e estrangeiros da época, afirmou o autor que "[S]e o poder regulamentar é em princípio e dominantemente exercido pelo Presidente da República, em razão de sua competência constitucional, nada impede - antes em determinadas circunstâncias aconselha - possa a lei habilitar outras autoridades à prática do poder normativo" 181 .

Em outra passagem no mesmo texto, afirma o autor ${ }^{182}$ :

"É sobretudo no direito econômico, área crescente de intervencionismo estatal, que se multiplica a atividade regulamentar exercida pelas agências administrativas incumbidas do controle do Estado sobre a economia. Impõe-se assegurar aos organismos administrativos uma agilidade de adaptação às exigências mutáveis dos fenômenos financeiros e econômicos que leva necessariamente à ampliação do poder de editar normas".

\footnotetext{
178 Op. cit., p. 499.

179 Comissão de Valores Mobiliário. Poder regulamentar. Temas de Direito Público, 2º vol., 1997, p. 1.075 a 1.093. Artigo publicado originalmente na Revista da CVM - abril-junho, 1986.

${ }^{180}$ Art. 84. Compete privativamente ao Presidente da República: (...)IV - sancionar, promulgar e fazer publicar as leis, bem como expedir decretos e regulamentos para sua fiel execução”.

${ }^{181}$ Comissão..., cit., p. 1.079 .

${ }^{182}$ Idem, p. 1.084.
} 
Ou seja, para tal publicista, baseado em texto normativo idêntico ao da nossa atual Constituição, inexiste qualquer tipo de monopólio da atividade normativa da Administração Pública pelo Presidente da República, uma vez que dita "norma de competência do Presidente da República é enumerativa, não sendo válido o raciocínio $a$ contrario sensu, excludente de outra fórmula de ação normativa que a discricionariedade do legislativo entenda necessária ou conveniente" ${ }^{183}$.

Outro administrativista, VICTOR NUNES LEAL, duplamente injustiçado - uma vez por ter aposentado compulsoriamente do cargo de Ministro do Supremo Tribunal Federal pelo regime militar ${ }^{184}$ e outra vez por suas lições terem sido praticamente abandonadas pelos principais autores de manuais do direito administrativo contemporâneos, vedando que seus ensinamentos chegassem às futuras gerações -, também teceu importantes comentários a respeito da delegação legislativa.

Em texto publicado em $1945^{185}$, referido autor tratou da distinção entre lei e regulamento, asseverando, com base nas lições de Léon Diguit, que, do ponto de vista material e substancial, o regulamento se equipara à lei, na medida em que contem as mesmas características que esta, de tal forma que o regulamento seria lei em sentido material. A distinção entre eles está no aspecto formal, tendo em vista que o regulamento é ato infralegal, a que pode ser submetido a controle de legalidade.

Em artigo publicado originalmente em julho de $1946^{186}$, ou seja, durante os trabalhos da Assembleia Constituinte que gerou a Constituição promulgada em setembro daquele ano, o autor teceu críticas à vedação à delegação legislativa, instituída

\footnotetext{
${ }^{183}$ Idem, p. 1.088.

${ }^{184}$ Por meio do Ato Institucional $n^{\circ} 5$ (AI-5), que também aposentou compulsoriamente os Ministros Hermes Lima e Evandro Lins e Silva.

${ }^{185}$ Lei e regulamento, publicado originariamente na Revista de Direito Administrativo no 1, jan. 1945, p. 371 e segs., e posteriormente republicado na coletânea Problemas de Direito Público, 1960, p. 57-91. As menções ao texto no nosso trabalho se referem à esta última publicação. Para um aprofundamento do pensamento de Victor Nunes Leal a respeito das relações entre lei e regulamento, conferir o excelente artigo de JEAN PAUL CABRAL VEIGA DA RochA, Regulação econômica e separação de poderes: a delegação legislativa na tradição do direito público brasileiro, in Alexandre Santos de Aragão (coord.) Revista de Direito da Associação dos Procuradores do Novo Estado do Rio de Janeiro, vol XI Direito da Regulação, 2002, p. 69-87.

${ }^{186}$ Delegações legislativas, publicado originariamente na Revista de Direito Administrativo $\mathrm{n}^{\mathrm{o}} 5$, jul. 1946, p. 378 e segs., e posteriormente republicado na coletânea Problemas de Direito Público, 1960, p. 92-108. As menções ao texto no nosso trabalho se referem à esta última publicação.
} 
pelo constituinte ante o receio dos abusos do Executivo praticados no período da ditadura Vargas, durante a vigência da Constituição de 1937, que permitia expressamente a delegação legislativa (art. 12).

No entanto, afirma o autor, a experiência de agigantamento do Executivo vinda do Estado Novo em virtude da delegação legislativa da Constituição de 1937 não poderia servir de base para a vedação à tal prática, pois em referido período o Executivo era a única fonte legislativa, ante a ausência de Parlamento. Nas palavras do autor:

\begin{abstract}
"No Estado Novo, o governo era a única agência legislativa, pois não havia parlamento que estabelecesse as diretrizes da legislação ou pudesse revogar as leis em que o executivo fizesse mau uso da autorização recebida. As delegações, que as leis costumavam fazer em favor dos regulamentos, tinham uma valor meramente jurídico, de puro interêsse técnico, mas sem qualquer alcance político, porque em tais casos era o Presidente quem autorizava o próprio Presidente a dispor, em decretos, sobre aquilo que êle mesmo deixara de regular nos decretos-leis. Não é possível confundir semelhante situação com as delegações legislativas feitas pelo Congresso ao Chefe do Executivo"187.
\end{abstract}

Ao lado desta verificação de um "êrro de confundir coisas diversas", coloca o autor que outra razão para a vedação às delegações legislativas seria o conservadorismo da Constituinte, que teria receio no apressamento das reformas sociais que as circunstâncias impõem.

Ainda de acordo com o autor, a vedação à delegação legislativa traria o problema de se verificar o conceito de regulamento. Com efeito, no regime de delegação legislativa, o conceito de regulamento é mais simples, uma vez que "bastará que se contenha nos limites da lei para que o regulamento seja válido e eficaz podendo, por isso mesmo, abrigar inovações expressa ou implicitamente permitidas pela lei" "188. Por outro lado, no regime da vedação à delegação legislativa, o conceito de regulamento é mais dificultoso e elaborado, tendo em vista que "não bastará verificar a sua concordância com a lei; também será imprescindível apurar se a lei regulamentada, nas margens ou nos claros que deixou ao regulamento, infringiu ou não o princípio das delegações legislativas" ${ }^{189}$.

\footnotetext{
${ }^{187}$ VICTOR NUNES LEAL, Delegações..., cit., p. 98.

${ }^{188}$ Op. cit., p. 100.

${ }^{189}$ Idem, ibidem.
} 
E, devendo caber ao Judiciário a análise da legalidade dos regulamentos, afirmava o autor que à jurisprudência que caberia trazer os contornos de tal poder regulamentar, como ocorreu sob a égide da Constituição de 1891. Nesta fase, a despeito de não vedada a delegação legislativa, a jurisprudência do Supremo Tribunal Federal, a despeito de considerar tal delegação como vedada, ampliou o poder regulamentar do Executivo, por meio da permissão a que os regulamentos pudessem inovar na matéria legislada, com o saneamento de lacuna do legislador.

Ou seja, mesmo havendo à época a consideração da invalidade da delegação legislativa, as contingências sociais e econômicas implicariam na chancela jurisprudencial da elasticidade do poder regulamentar da Administração. Assim, seja pela delegação legislativa, seja pelo poder regulamentar estendido, o resultado seria o mesmo: a permissão ao Executivo para a produção de regulamentos tidos como lei em sentido material ${ }^{190}$.

E foi justamente o que ocorreu, com o Supremo Tribunal Federal sendo chamado a se manifestar por diversas vezes a respeito da atividade normativa elaborada pela Administração, sendo que o Tribunal ora recusou a existência de delegação legislativa, atribuindo tal competência ao exercício de atividade normativa do Executivo, ora reconheceu a existência de delegação legislativa nas matérias que envolviam o direito econômico ${ }^{191}$.

Ora, nem mesmo durante a vigência da Constituição de 1946, cujo artigo 36, $\S 3^{\circ}$, expressamente vedava tal prática, foi possível a negação da delegação legislativa, justamente em virtude da ampliação das tarefas atribuídas à Administração Pública no decorrer do século XX. Em tal cenário, o natural, e mesmo desejável, é que sejam deixados cada vez maiores espaços para a atividade legislativa da Administração

\footnotetext{
${ }^{190}$ É o quanto assevera JeAn PAUL CABRAL VeIGa DA Rocha, ao afirmar que o que Victor Nunes Leal tenta mostrar "é que a consagração constitucional da proibição expressa e absoluta das delegações legislativas não terá efetividade ou eficácia social. O Estado contemporâneo não funciona sem mecanismos de transferência de função legislativa para o Executivo. Se os constituintes, num gesto de reação contra a herança varguista, conseguissem proibir as delegações legislativas, o processo político levaria à sua permissão por outro meio: a extensão do poder regulamentar via interpretação judicial. Delegação legislativa e ampliação do poder regulamentar são, portanto, formas jurídicas distintas de se atingir o mesmo resultado: permitir que o Executivo produza lei em sentido material". (Regulação econômica..., cit., p. 78).

${ }^{191}$ A respeito da análise dos julgamentos do STF em tal período, cf. JULIANA BONACORSI DE PALMA,
} Atividade normativa..., cit., p. 62-64. 
Pública, o que se dará por meio da edição de atos normativos, delimitados pela própria lei estatuída pelo Legislativo.

A síntese do desenvolvimento do direito administrativo sob a égide da Constituição de 1946 foi bem pontuada por JULIANA BONACORSI DE PALMA:

\begin{abstract}
"O período do desenvolvimento teórico do Direito Administrativo sob a égide da Constituição de 1946 é mercado, no que toca à atividade regulamentar administrativa, pela contradição entre uma Constituição de extraordinária valorização da lei formal frente ao regulamento e a prática administrativa, o que deu conta a jurisprudência do Supremo à época. Também é um período de dissenso doutrinário: autores foram mais favoráveis à atividade administrativa normativa, o que não implica em desprezo à regra da primazia da lei, enquanto outros defenderam a contenção da esfera regulamentar na Administração Pública. Esse é o retrato do cenário típico de construção das ideias sobre a atividade normativa da Administração Pública na tradição brasileira"192.
\end{abstract}

Tais lições de administrativistas do passado e do presente, bem como os próprios precedentes do Supremo Tribunal Federal nos colocam diante da questão de verificar qual seria o fenômeno jurídico a fundamentar a utilização da competência normativa da Constituição em parâmetros aparentemente contrários tanto à Constituição de outrora, quanto à Constituição hoje vigente no Brasil. Em nosso sentir, tal fenômeno se explica pela mutação constitucional.

Tal fenômeno da mutação constitucional é intimamente ligado à alteração do sentido dos textos plasmados na Constituição, de acordo com as alterações no contexto histórico-social ou fático-axiológico em que aplicado o preceito da Lei Maior ${ }^{193}$.

Com efeito, como bem anota KARL LOWENSTEIN ${ }^{194}$, a Constituição reflete o status quo do momento em que é editada, mas deve ser tratada como um organismo vivo, sempre em movimento e submetido à dinâmica da realidade em que inserida, de tal forma que não pode ser captada por meio de fórmulas fixas e imutáveis, o que implica em acomodações do texto constitucional à realidade. Assim, a despeito de o texto constitucional ser o mesmo, não sofrer qualquer tipo de alteração em sua redação, as alterações na realidade sobre a qual a norma incidirá implica na alteração do

\footnotetext{
${ }^{192}$ Atividade normativa..., cit., p. 66.

193 GILMAR FERREIRA MENDES et alli, Curso de direito constitucional, 2007, p. 123.

${ }^{194}$ Teoria..., cit., p. 164.
} 
conteúdo normativo do texto, de modo que são alterados o sentido e o alcance da norma constitucional $^{195}$.

Na mesma linha, GEORG JELLINECK ${ }^{196}$, retomando o velho brocardo omne ius consensus fecit, aut necessitas constituit, aut firmavit consuetudo, aponta que a necessidade (necessitas) é pouco lembrada como uma das fontes do direito, a despeito de ser de fundamental importância para a vida das Constituições, seja no que se refere a momentos cruciais da história dos Estados (como revoluções e usurpações, importantes para o aspecto constitucional), seja no que se refere ao curso normal da vida destes. De acordo com o autor germânico, é justamente em virtude da necessitas que a organização estatal poderá ser alterada sem a modificação do texto constitucional.

No que se refere aos fatores que levam à mutação constitucional, GILMAR Ferreira Mendes, Inocêncio Mártires Coelho e Paulo Gustavo Gonet Branco afirmam:

\footnotetext{
"Vistas a essa luz, portanto, as mutações constitucionais são decorrentes - nisto residiria a sua especificidade - da conjugação da peculiaridade da linguagem constitucional, polissêmica e indeterminada, com os fatores externos, de ordem econômica, social e cultural, que a Constituição - pluralista por antonomásia -, intenta regular e que, dialeticamente, interagem com ela, produzindo leituras sempre renovadas das mensagens enviadas pelo constituinte" ${ }^{\text {197 }}$.
}

O que nos parece claro, então, é que a delegação legislativa pode ser explicada, ainda que a doutrina analisada anteriormente não a mencione, pelo fenômeno da mutação constitucional, de tal forma que as necessidades da realidade sobre a qual o texto constitucional era e é aplicado levaram à adoção da delegação, com a finalidade de suprir a necessidade de regular os setores econômicos de acordo com agilidade e precisão incompatíveis com a função desempenhada pelo Legislativo.

Justamente por estas três razões expostas entendemos ser a delegação legislativa a melhor teoria para explicar a competência normativa das agências

\footnotetext{
195 Luís Roberto BARroso, Curso de direito constitucional contemporâneo: os conceitos fundamentais e a construção do novo modelo, 2009, p. 123 e 126.

${ }^{196}$ Reforma y mutacion de la constitucion, 1991, p. 29.

${ }^{197}$ Curso..., cit., p. 123.
} 
reguladoras, pois não se destaca dos contextos social e econômico em que gerada, sendo, na realidade, fruto destes, o que a torna fenômeno inevitável.

\section{II.B - A Expedição do Ato Normativo Regulatório Enquanto Atividade Processualizada: A Legitimação pelo Procedimento}

Conforme visto no capítulo anterior, o decorrer do século XX levou à pluralização da sociedade, que passou a contar com diversos grupos antagônicos que lutam entre si para que suas pretensões sejam atendidas pelo Estado, de tal forma que a Administração Pública passa a atuar como árbitra e ponderadora de todos esses interesses. Diante disto, como dito no capítulo anterior, desaparece a separação total entre as esferas do público e do privado, o que se dá pelo reconhecimento de que nem sempre os interesses privados são antípodas ao interesse público, mas, ao contrário, por vezes, o atendimento ao interesse privado significará justamente a realização do interesse público ${ }^{198}$.

Assim, um dos pilares sobre o qual recaiu a formação do Estado Moderno, a unicidade do interesse público, finalidade do agir estatal e base para a separação entre o público e o privado $^{199}$, passa a ser questionada, podendo-se falar em pluralidade de

\footnotetext{
${ }^{198}$ Dois exemplos de atingimento do interesse público pela consecução de um interesse particular podem ser aqui apresentados. Em primeiro lugar, temos a recomposição do equilíbrio econômico-financeiro dos contratos administrativos, nas hipóteses em que, durante a execução do contrato, houver ocorrido o desequilíbrio da equação encargos-remuneração inicialmente previstas quando da apresentação das propostas na licitação. Não se nega que ao Estado interessa obter o melhor serviço prestado pelo menor preço. No entanto, isto não significa dizer que o interesse público estará alcançado se o particular contratado for obrigado a prestar o serviço contrato em situação de prejuízo financeiro, notadamente porque a não recomposição do equilíbrio econômico-financeiro traria prejuízos ao Estado a longo prazo, seja por meio do aumento dos valores das ofertas feitas por privados em certames licitatórios, uma vez que o risco de vir a ser obrigado a prestar serviço em situação de prejuízo financeiro seria precificado na proposta, seja por meio da não participação de empresas capacitadas tecnicamente em certames licitatórios por saberem que, em determinado momento do contrato, serão obrigadas a prestar os serviços de forma deficitária economicamente. (A respeito da manutenção do equilíbrio econômico-financeiro do contrato como manifestação do interesse público, cf. CELSO ANTÔNIO BANDEIRA DE MELLO, O equilíbrio econômico nos contratos administrativos, in

Grandes Temas de Direito Administrativo, 2009, p. 212-214). Outro exemplo pode ser verificado nos tratamentos de saúde financiados com recursos públicos. Do ponto de vista orçamentário, pode ser que o interesse Estado seja o de que cada particular arque com os custos dos seus próprios tratamentos. No entanto, o interesse público da sociedade difusamente considerada reside na prestação dos serviços de saúde a cada um dos particulares. Assim, o particular que vai ao posto de saúde para fazer algum tratamento médico, ao mesmo tempo em que tem o seu interesse privado atendido, acaba por atender também ao interesse público.

${ }^{199}$ A respeito da separação e antinomia entre o interesse público e os interesses privados, preciso é o diagnóstico de VITOR RHEIN SCHIRATO: "Muito embora sempre tenha havido, em grau maior ou menor de centralização, uma autoridade com poder de interferir na vida dos cidadãos, a existência de uma autoridade central desvinculada da figura do soberano e submetida à ordem jurídica é, sem dúvida, o
} 
interesses públicos, todos eles a priori legítimos e exigíveis do Estado. Aponta a esse respeito Floriano de Azevedo Marques Neto, que "[A] sociedade fragmentada não se coaduna com um enquadramento, mesmo teórico, em um bloco homogêneo, inviabilizando os princípios de pretensão uniformizadora." ${ }^{200}$, e arremata ao afirmar que "em sociedades pluralistas, como a que vivemos, há tantos interesses públicos quantas forem as comunidades nela coexistentes" ${ }^{201}$.

Dentro de um ambiente de pluralidade de interesses públicos (= interesses legítimos a priori), vale, mais uma vez, a colocação do autor supra mencionado, no sentido de que

\begin{abstract}
"[O] princípio da supremacia do interesse público, parece-nos, deve ser aprofundado de modo a adquirir a feição da prevalência dos interesses públicos e desdobrando-se em três subprincípios balizadores da função administrativa: (i) a interdição do atendimento de interesses particularísticos (v.g., aqueles desprovidos de amplitude coletiva, transindividual); (ii) a obrigatoriedade de ponderação de todos os interesses públicos enredados no caso específico; e (iii) a imprescindibilidade da explicitação das razões de atendimento de um interesse público em detrimento dos demais" ${ }^{\prime 202}$.
\end{abstract}

Ora, na medida em que o Estado reconhece (i) a existência de interesses contrapostos entre os vários grupos sociais; (ii) que tais interesses não se confundem com o interesse público uno, mas representam diversos interesses públicos a priori; (iii) que a legitimidade das decisões públicas não decorre mais do simples cumprimento da lei - até mesmo por que está é cada vez mais aberta às interpretações -, mas sim da verificação e ponderação dos interesses contrapostos no caso concreto, somente resta ao Estado chamar todos os interessados para debaterem em um procedimento regrado e pré-estabelecido, com a finalidade de se verificar quais são os interesses em jogo e qual(is) dele(s) prevalecerá(ão) e em que medida.

marco fundamental para que se comece a pensar em uma Administração Pública tal como hoje a conhecemos. Verifica-se a existência a partir deste momento, de um Estado sujeito de direitos e obrigações e exercente de distintas funções (jurisdicional, legislativa e executiva), com a finalidade de garantir a ordem pública. Desta forma, é possível afirmar que a concepção iluminista do Estado como a centralização do poder necessária para a realização do bem comum, sobretudo esteada em Hobbes e Rousseau, fez ser atribuída ao Estado uma necessária posição de supremacia em relação aos cidadãos. Afinal, ao Estado caberia, por meio da centralização do poder, realizar o interesse da coletividade e garantir a ordem pública. Ao passo que aos particulares caberia apenas perseguir seus interesses, em detrimento do interesse público, coletivo, não sendo, portanto, cogitável a existência de um regime partidário ou menos verticalizado na relação entre Estado e particulares. O interesse particular, nesta construção, é sempre contrário ao interesse público, justificando sua submissão". (O processo administrativo como instrumento do Estado de Direito e da Democracia, in Odete Medauar e Vitor Rhein Schirato (org.) Atuais Rumos do Processo Administrativo, 2010, p. 11-12).

${ }^{200}$ Regulação estatal...cit., p. 151.

201 Idem, p. 152.

${ }^{202}$ Idem, p. 165. 
Nesse passo, o instrumento colocado à disposição do Estado para verificar e ponderar os interesses conflitantes em determinado caso concreto é o processo administrativo, não mais visto na visão tradicional, como instrumento pelo qual se concretizam os comandos legais, as decisões antecipadamente fornecidas pela lei, sendo o processo mero meio de sua concretização, mas sim como instrumento voltado à efetiva participação dos interessados na decisão administrativa ${ }^{203}$, sendo "veículo para a criação da utilidade pública, para produção de decisões que não estão antecipadamente dadas"204, o que se dará largamente no âmbito da criação de políticas públicas e, para os fins do presente estudo, de políticas regulatórias. Passa-se, então, a considerar o processo administrativo como um instrumento eficaz para a verificação e ponderação

\footnotetext{
${ }^{203} \mathrm{Na}$ realidade, tal mudança de forma de atuação administrativa, que deixa de ser focada no ato administrativo unilateral e passa a ser vista sob o ponto do processo administrativo representa muito mais do que uma simples alteração de modus operandi, para atingir a própria mudança na relação entre Administração e cidadão. Com efeito, há uma nítida mudança na posição do administrado, que deixa de ser encarado pela Administração como súdito, sempre submisso às determinações estatais, e passa a ser encarado como um sujeito de direitos oponíveis contra o próprio Estado, o que implica na necessidade de que este, ao agir, leve em consideração os interesses legítimos daquele.

Na lição de FloRIANO DE AZEVEDo MARQUES NETO, a visão tradicional do direito administrativo tendo como objeto central o ato administrativo tinha como pressuposto uma situação mais passiva do indivíduo frente à Administração Pública, "podendo eventualmente provocar uma atuação administrativa, mas fundamentalmente sendo objeto do agir administrativo que, balizado pela lei, editaria atos de efeitos concretos (constitutivos ou restritivos de direitos) sobre o indivíduo". Prossegue o Professor Titular do Largo de São Francisco afirmando que "esta noção se apoia na ideia de autoridade como fonte do ato administrativo. Confere pouca - ou talvez, nenhuma - importância ao administrado, reduzido a sujeito do provimento administrativo, seja como beneficiário, seja como detentor de direitos a sofrer ablação." (A superação do ato administrativo autista, in Odete Medauar e Vitor Rhein Schirato (coord.). Os Caminhos do Ato Administrativo, 2011, p. 95). Na mesma linha é o quanto ensina JACQUES CHEVALLIER: "Essa perspectiva modifica profundamente o sentido da relação administrativa e a lógica sobre a qual foi edificada a instituição administrativa. Abandonando o estatuto tradicional de súdito constrangido a submeter-se às prescrições administrativas, ou de simples consumidor passivo de prestações cuja consistência não pode negociar, o administrado, promovido ao nível de "ator", vê a si reconhecido um direito de fiscalização, uma capacidade de influência sobre o funcionamento dos serviços. Correlativamente, a administração, convidada a abrir-se aos seus usuários, é conduzida a renunciar a determinados traços essenciais da personalidade burocrática para "democratizar-se": melhor ainda, ela se torna um lugar privilegiado de realização da exigência democrática. Essa mutação testemunha o alargamento e o aprofundamento da concepção da democracia nas sociedades contemporâneas: não apenas o jogo representativo não responde mais aos anseios dos cidadãos, mas ainda esses não aceitam mais um modelo de relações administrativas fundado sobre o distanciamento e unilateralidade; a democratização do funcionamento administrativo permite satisfazer ao mesmo tempo as duas aspirações. Por essa via, produz-se o esmaecimento da tradicional separação estabelecida na teoria liberal entre as duas faces (política/administrativa) da relação com o Estado: trata-se de romper com a concepção do administrado-súdito, centrando a questão da relação administrativa em torno dos direitos dos cidadãos num Estado democrático; na sua relação com a administração, o administrado deve ser considerado primeiramente e sempre como um cidadão". (O Estado..., cit., p. 230-231).

${ }^{204}$ CARLOS ARI SUNDFELD, Processo administrativo: um diálogo necessário entre Estado e cidadão, in
} Revista de Direito Administrativo e Constitucional, 2006, versão digital. 
dos diversos interesses colidentes no caso concreto, através da mediação entre eles e o diálogo entre os detentores dos interesses legítimos ${ }^{205}$.

Tal processualização da atividade administrativa possui três consequências marcantes para a expedição de atos administrativos ${ }^{206}$ : (i) a primeira se refere à permeabilidade que a edição do ato administrativo deve ter aos interesses que serão por ele afetados, de tal forma que todos estes deverão ser levados em consideração pela autoridade ao editar o ato administrativo; (ii) a segunda trata da necessidade de que o ato administrativo não seja meramente editado de acordo com as balizas postas pela lei, mas que tenha um olhar prospectivo, com a ponderação e análise dos impactos da decisão administrativa nos diversos interesses envolvidos no caso concreto, fundamentação da alternativa adotada etc.; (iii) por fim, a terceira consequência se refere à unilateralidade reflexiva do ato administrativo, que significa que as diversas posições e interesses conflitantes na situação em apreço pela autoridade administrativa devem ser consideradas na expedição do ato, inclusive para fins de motivação, de tal modo que, a despeito do caráter unilateral do ato - afinal, não se trata de negócio jurídico administrativo -, tal característica deve ser analisada à luz do conflito de interesses subjacente à expedição do ato.

\section{II.B.1 - A Legitimidade Democrática das Agências Reguladoras}

Esta nova forma de legitimidade das ações estatais está intimamente ligada ao tema do presente trabalho, notadamente ao tema da legitimidade das agências reguladoras.

Conforme verificado no capítulo anterior, as necessidades conjunturais do final do século XX levaram à necessidade, nos países filiados ao direito administrativo

\footnotetext{
${ }^{205}$ Na lição de VITOR RHEIN SCHIRATO: "Há enorme gama de interesses coletivos legítimos, que devem ser considerados na escolha do daquele que deverá prevalecer no caso concreto. Em um contexto democrático em que todos gozam de plena igualdade perante a Administração Pública e no qual diversos atores têm interesses diversos (e não raro contraditórios) com relação a uma decisão, é essencial que cada um possa expor seu ponto de vista e suas razões com relação ao caso concreto, de forma a permitir à Administração Pública, em sua função de mediação, identificar qual o interesse que deverá prevalecer. A garantia do direito de participação no processo decisório do Estado não é, neste contexto, apenas um formalismo decorrente da concepção de democracia, mas sim é um elemento essencial para que a decisão tomada reflita a ponderação de todos os interesses existentes e que são manifestados no exercício de direitos democráticos." (O processo administrativo...cit., p. 40).

${ }^{206}$ Floriano DE AZEVEDO MARQUES NETO, A superação..., cit., p. 110.
} 
europeu continental, da criação de entes reguladores de atividades econômicas (em sentido amplo) dotados de independência gerencial, administrativa e financeira do Poder Central do Estado. No Brasil, tais entes criados são as agências reguladoras.

Elevados à categoria de autarquias em regime especial, a atividade normativa de tais entes é, como sempre foi, objeto de críticas a respeito da sua legitimidade democrática, que podem ser verificadas em dois sentidos: (i) num primeiro plano, o objeto de questionamento é a própria capacidade normativa de tais entes, na medida em que podem normatizar o setor regulado de acordo com as diretrizes legais e constitucionais, o que seria, para boa parte dos publicistas pátrios, usurpação da função legislativa; e (ii) num segundo plano, o objeto de questionamento é a própria independência de tais entes em relação à Administração central, na medida em que a concessão de mandatos fixos aos seus dirigentes, não demissíveis ad nutum, pode ser considerada como uma afronta à legitimidade democrática do Chefe do Executivo, tendo em vista que a troca deste não implica na substituição daqueles.

O primeiro ponto de crítica, a respeito da usurpação da função legislativa foi analisado no item II.A.2 do presente capítulo, de tal modo que iremos agora nos debruçar sobre o segundo aspecto da legitimidade da atividade normativa de tais entes.

O questionamento feito à legitimidade da função normativa das agências reguladoras decorre, basicamente, de um aparente conflito entre o insulamento burocrático de tais entes e a possível diretriz antidemocrática das políticas setoriais tomadas, muitas vezes, em sentido oposto aos interesses do Chefe do Executivo, eleito democraticamente ${ }^{207}$.

\footnotetext{
${ }^{207}$ A questão a respeito da legitimidade democrática das agências foi bem sintetizada por PAULO TODESCAN LESSA MATTOS, nos seguintes termos: "Nesse ponto, o que está em questão é saber em que medida pode ser legítima e democrática a decisão sobre o conteúdo da regulação por um órgão colegiado não eleito e com autonomia decisória em relação à administração direta, em contraposição à decisão monocrática de um ministro de Estado nomeado pelo Presidente da República, este sim eleito pelo voto popular. Ou, ainda, em que medida é legítima a definição de políticas públicas para um setor da economia por meio de uma agência reguladora independente, na medida em que, ao exercer sua função normativa, acaba por especificar (exercendo efetivamente poder normativo) o conteúdo das normas gerais definidas pelos Poder Legislativo (eleito) ou em decreto do Presidente da República (eleito)". (O novo estado regulador no Brasil: eficiência e legitimidade, 2006, p. 207).
} 
Com efeito, para tal corrente, da qual são representantes no Brasil autores como Eros Roberto GraU ${ }^{208}$ e Celso Antônio Bandeira De Mello ${ }^{209}$, a existência de mandatos fixos aos dirigentes das agências reguladoras com prazos superiores aos do Chefe do Executivo, o que é previsto em diversas leis criadoras de tais entes, representaria "fraude contra o próprio povo" ${ }^{10}$, uma vez que a diretriz imposta à Administração Pública pelo governante anterior seria perpetuada no posterior por meio de tais dirigentes.

No entanto, com o devido respeito a tais Professores, entendemos que a mudança do eixo democrático acima apontada, ou seja, a quebra do monopólio da urna como o centro da democracia contemporânea, implica na valorização do procedimento participativo, que nada possui de antidemocrática.

Em primeiro lugar, pela Teoria dos Poderes Neutrais, é necessária a criação de "órgãos estatais com autonomia de gestão e independência funcional para, fora do círculo político-eleitoral, controlar e equilibrar as relações entre os titulares dos cargos eletivos para assegurar a observância dos valores maiores da coletividade" ${ }^{211}$.

Assim, é ínsito à democracia a existência de órgãos infensos às pressões políticas e que se destinem a assegurar direitos e interesses que não possam ficar à mercê da alteração de diretriz política. São exemplos de órgãos criados em virtude de tal teoria os tribunais de contas, as cortes constitucionais, os conselhos com sede constitucional e as agências independentes, todos eles dotados das seguintes características: (i) não eletividade popular dos titulares; (ii) desempenho de funções predominantemente técnicas; (iii) independência em relação ao poderes políticos exercidos pelos detentores de mandatos eletivos populares, o que permite (iv) a atuação imparcial em relação aos diversos interesses privados em jogo, aos interesses do Estado e à vontade majoritária da sociedade ${ }^{212}$.

\footnotetext{
208 As agências, essas repartições públicas, in Calixto Salomão Filho (coord.). Regulação e Desenvolvimento, 2002, p. 25-28.

${ }^{209}$ Curso..., cit., p. 178-180.

${ }^{210}$ Idem, p. 180.

${ }^{211}$ AlEXANDRE SANTOS DE ARAGÃo, Agências reguladoras...,cit., p. 441.

${ }^{212}$ Idem, ibidem.
} 
Em virtude destas características, aponta AlEXANDre SANTOS dE ARAgÃo que estes poderes neutrais "longe de serem antinômicos à democracia em razão da possibilidade de contradição com as forças políticas majoritárias, asseguram o pluralismo no seio do Estado sem retirar totalmente os poderes do Chefe do Poder Executivo e do Poder Legislativo", de tal forma que se revelam como "uma feliz combinação do pluralismo (propiciado por sua autonomia 'reforçada') com o princípio majoritário (os vínculos que mantêm como Poder Legislativo e com a Administração central)" ${ }^{213}$.

Em segundo plano, na lição de GIANDOMENICO MAJONE ${ }^{214}$, o modelo majoritário de democracia não é o único possível, podendo ser adotado o modelo de legitimidade procedimental, que permita a participação dos cidadãos e, principalmente, a transparência na tomada de decisões públicas que gere responsabilização do órgão regulador.

Assim, para que este novo padrão de legitimidade - procedimental - seja implementado, é necessário, conforme visto no item anterior, que ocorra a efetiva participação do administrado na formação do agir administrativo, o que se dará pelos procedimentos e meios postos à disposição para que os diversos grupos conflitantes possam apresentar argumentos em defesa de seus interesses, bem como ver estes argumentos levados em consideração na tomada das decisões.

No âmbito das agências reguladoras, a legitimidade democrática se dará justamente pela abertura à possibilidade de os diversos interessados na expedição do ato normativo regulatório influírem na tomada da decisão do ente, o que se dará por meio da permeabilidade de tais entes aos diversos interesses conflitantes e pela processualização da sua atividade normativa.

Com relação à permeabilidade ${ }^{215}$, ela significa que as agências devem ser entes constantemente abertos ao diálogo com os atores sociais, sob pena de haver risco à legitimidade da regulação, eis que esta será imposta unilateralmente aos regulados, o

\footnotetext{
${ }^{213}$ Op. cit., p. 442.

214 Do estado positivo ao estado regulador, in Paulo Todescan Lessa Mattos (coord.). Regulação Econômica e Democracia: o Debate Europeu, 2006, p. 76-77.

${ }^{215}$ Floriano de Azevedo Marques Neto, Agências reguladoras..., cit., p. 63-66.
} 
que implica em capacidade reduzida de aceitação das diretrizes administrativas a médio e longo prazo.

Nesse passo, a permeabilidade das agências deve permitir que todos os atores do setor regulado participem da tomada de decisões, com a finalidade de poderem influir e tentar fazer prevalecer seus interesses para o setor, o que implica, então, na oitiva constante dos prestadores da utilidade, dos consumidores, dos financiadores e, inclusive, dos potenciais beneficiários da atividade regulada, de tal modo que os possíveis atingidos pela ação regulatória devem possuir um espaço para a interlocução.

No âmbito legislativo nacional, diversas leis criadoras de agências reguladoras estipulam procedimentos prévios à expedição ou alteração de atos normativos, conforme se verifica, por exemplo, dos artigos 17 a 19 da Lei ${ }^{\circ}$ 9.478/97 (ANP), o artigo 42 da Lei $n^{\circ}$ 9.472/97 (ANATEL), art. 63 da Lei n 10.233/01 (ANTT e ANTAQ) etc.

De tudo o que foi exposto, é possível concluir, então, que a legitimidade democrática das agências reguladoras reside justamente na procedimentalização da sua atividade normativa o que implicará na necessidade de analisarmos quais os requisitos a serem observados por referidas entidades, com a finalidade de legitimar tal competência.

\section{II.B.2 - A Atividade Normativa das Agências Reguladoras}

Analisar a normatização por agências independentes como atividade significa que entendemos que a legítima regulação deve ser feita mediante um procedimento que permita a participação de todos os interessados e, mais que isto, que os interesses de todos os participantes do processo sejam devidamente analisados e ponderados pela autoridade.

Como no Brasil e nos países europeus de tradição continental o surgimento das agências reguladoras independentes é deveras recente, entendemos que o estudo da procedimentalização da atividade normativa deve tomar como base o estudo do 
rulemaking do direito norte-americano, por possuir grande desenvolvimento teórico no que se refere à participação dos interessados e aos limites impostos à Administração.

\section{II.B.2.1 - Breve Panorama do Rulemaking Norte-Americano}

Tratar da função normativa das agências reguladoras implica na necessidade de se analisar, ainda que de modo superficial ${ }^{216}$, o rulemaking do direito administrativo norte-americano- notadamente no que se refere aos limites por impostos à atividade normativa das agências -, sem que isto represente qualquer deferência de nossa parte aos institutos de tal tradição jurídica, ou mesmo que entendamos possível a importação destes sem qualquer temperamento para o Direito brasileiro.

O fato é que a republicização de atividades antes de prestação exclusiva do Estado implica na reconfiguração do direito administrativo nacional, baseado primordialmente na tradição europeia continental, passando a ser mais permeável a institutos e regras do direito norte-americano, ante a identidade de situações referentes à regulação de atividades.

Com efeito, o direito administrativo norte-americano, diversamente do direito europeu continental, não estabeleceu a noção de serviço público enquanto atividade monopolizada pelo Estado, ou seja, interditada à iniciativa privada. De acordo com Floriano DE AZEVEDo MARques Neto, “a construção da estrutura econômica e jurídico-institucional que nascia com a Declaração de Independência guardava enorme antipatia com qualquer espécie de privilégio, inadmitia atividades reservadas ou monopolizadas e, por conseguinte, rejeitava institutos como o serviço público e o contrato administrativo"217.

Assim, as atividades econômicas em geral foram prestadas pela iniciativa privada, sendo que o Estado, pouco a pouco, ao longo do século XIX, passou a intervir em tais atividades, com a finalidade de evitar que os detentores das public utilities (bens

\footnotetext{
${ }^{216}$ Para um panorama aprofundado a respeito do rulemaking norte-americano, cf. JULIANA BONACORSI DE PALMA, Atividade normativa..., cit., p. 224-274, e SÉRgIO VARElla BRUNA, Agências reguladoras..., cit., p. 180-249.

${ }^{217}$ A concessão..., cit., p. 98
} 
ou serviços de interesse geral) abusassem dos seus monopólios e prejudicassem as atividades comerciais dos demais agentes econômicos.

Em um primeiro momento, conforme anota BERTRAND DU MARAIS ${ }^{218}$, tal intervencionismo estatal estava ligado às atividades de transporte ${ }^{219}$, com a finalidade de solucionar disputas entre transportadores e fazendeiros, estes últimos geralmente em situação de dependência em relação àqueles, bem como de lutar contra a concorrência desmedida entre detentores de redes de transportes.

Dentro deste cenário, a Suprema Corte norte-americana afirma, ao julgar o caso Munn vs Illinois, em 1877, que a intervenção estatal em matéria de transporte e estocagem de grãos se justificava, pois, a partir do momento em que o prestador presta um serviço ao público, sua atividade se reveste de um interesse público e afeta a comunidade em geral, o que justifica a intervenção pública na regulação da atividade ${ }^{220}$.

Assim, a partir de tal decisão, o direito administrativo norte-americano passou a contar com a figura do regulador, o que foi desenvolvido ao longo do século $\mathrm{XX}$, mas sempre tendo por base a prestação de atividades de interesse coletivo por empresas privadas, sob regulação do poder público.

Paralelamente a tal construção dos norte-americanos, nos países nos quais o direito administrativo sofreu a influência da matriz europeia continental, os serviços de interesse coletivo eram de atribuição do Estado, o que gerou a noção de serviço público e implicou na vedação a que as atividades assim consideradas fossem de livre prestação pelos privados, somente sendo permitida a sua prestação pelo Estado ou quem lhe fizesse as vezes, o que implica na noção de publicatio $^{221}$.

De acordo com tal concepção de serviço público, é necessário que (i) tal atividade se constitua em monopólio estatal, bem como que, em decorrência disto (ii)

\footnotetext{
${ }^{218}$ Droit public de la régulation économique, 2004, p. 94.

${ }^{219}$ Nesse passo, por exemplo, uma das explicações para a criação da Interstate Commerce Comission (ICC), em 1877, a primeira agência reguladora criada nos Estados Unidos, é no sentido de que ela foi instituída para proteger os exportadores, especialmente os pequenos, do monopólio e dos custos de tarifa discriminatórios dos grandes transportadores. (STEPHEN G. BREYER et ali, Administrative law and regulatory policy: problems, texts and cases, $7^{\mathrm{a}}$ ed., 2011, p. 17.

${ }^{220}$ BERTRAND DU MAURAIS, Droit public..., cit., p. 95.

${ }^{221}$ Nesse sentido, cf. VITOR RHEIN SCHIRATO, Livre iniciativa nos serviços públicos, 2012, p. 88-90.
} 
que a prestação seja feita pelo Estado ou por quem lhe faças as vezes, o que implica na interdição à livre prestação entre os privados.

Diante de tal concepção, a regulação do serviço público se dava muito mais pela perspectiva e pelos interesses do próprio prestador, não tendo a intenção de tutelar os interesses dos usuários ${ }^{222}$, sendo tal arcabouço regulatório praticamente inservível para o cenário de concessões de serviços públicos e de competição entre prestadores, o que implica na necessidade de se buscar algum arcabouço teórico para respaldar a análise do poder normativo das agências independentes.

Logo, mais de um século antes de os países de tradição europeia continental, dentre os quais se inclui o Brasil, iniciarem os processos de privatização, o que levou à necessidade de uma regulação independente - o que veio a calhar na criação das agências reguladoras -, o direito administrativo norte-americano já iniciava a regulação independente, construindo ao longo do século XX um importante arcabouço teórico a respeito da normatização por agências reguladoras independentes, razão pela qual entendemos de extrema importância tecer alguns comentários a respeito de tal atividade administrativa.

O rulemaking é o processo de elaboração legislativa pelas agências reguladoras dos EUA, sendo previsto na Lei de Processo Administrativo daquele país - o Administrative Procedure Act (APA), de 1946 -, cuja preocupação se divide entre a necessidade de as agências procederem à oitiva prévia daqueles que vierem a ser atingidos pelo ato regulatório expedido, bem como com a qualidade da própria decisão expedida pelo regulador.

Conforme aponta SÉRgio VARElla BrunA, “o APA foi a forma encontrada para 'domar administradores mal-comportados', sem contudo privar a Administração da flexibilidade necessária à disciplina de condições sociais cada vez mais complexas" ${ }^{223}$, sendo um importante meio de controlar a atuação normativa da Administração, representando um importante mecanismo para limitar a influência política sobre a

\footnotetext{
${ }^{222}$ Floriano De AZEVEdo MARQUes Neto, A nova regulação..., cit., p. 77.

${ }^{223}$ Agências reguladoras..., cit., p. 201.
} 
tomada de decisões nos setores econômicos, com a limitação da discricionariedade $\operatorname{administrativa}^{224}$.

O rulemaking tem por finalidade precípua analisar se os interessados puderam ou não participar do processo de elaboração da norma regulatória, bem como se a norma regulatória decorrente do processo é racional, razoável, arbitrária ou se foi expedida com abuso de discricionariedade ${ }^{225}$, de tal forma que é a partir dos elementos do próprio processo que se instaura a possibilidade de revisão judicial da regulação.

O processo de elaboração normativa das agências norte-americanas possui, basicamente três fases ${ }^{226}$ : (i) a fase de proposta normativa, pela qual a agência é obrigada a divulgar à comunidade a intenção de publicar um regulamento; (ii) a fase de consulta pública, na qual as partes devem apresentar comentários escritos à proposta normativa, podendo fornecer dados e informações às agências; e (iii) a fase de decisão, na qual a agência deve analisar os elementos do processo e expedir uma fundamentação concisa, que não necessita de responder a todos os questionamentos feitos, mas apenas explicitar as razões escolhidas, de acordo com as finalidades legais perseguidas pela agência.

Vale notar, que a exigência da realização de um registro de todos os elementos do processo administrativo passou a ser fortalecida a partir dos anos de 1960, quando Suprema Corte passou a exigir que as agências possuíssem um registro (record) das questões que foram debatidas no processo administrativo, com a finalidade de que os interessados pudessem buscar no Judiciário a contestação do ato regulatório ${ }^{227}$.

Assim, de acordo com os registros do que ocorrera durante o procedimento regulatório tornou-se possível ao Judiciário exercer um controle a respeito dos aspetos procedimentais da atividade normativa das agências reguladoras, o que implicou, inclusive, na análise das questões de racionalidade e razoabilidade dos atos regulatórios, por meio da hard look doctrine que será analisada no próximo capítulo.

\footnotetext{
${ }^{224}$ Idem, p. 202.

${ }^{225}$ MARTIN SHAPIRO, Who guards the guardians? Judicial control of administration, 1988, p. 44.

${ }^{226}$ SÉRgio VARElla BRUNA, Agências reguladoras..., cit., p. 205 e segs.

227 Juliana Bonacorsi DE PALMA, Atividade..., p. 230 e segs.
} 
O que fica claro, então, é o processo de rulemaking possui grande preocupação com a participação efetiva dos interessados no setor regulado, com a finalidade de legitimar a atividade normativa das agências reguladoras, bem como com a motivação do ato, aspectos que possuem importância para o direito brasileiro.

\section{II.B.2.2 - A Atividade Normativa das Agências Reguladoras no Direito Brasileiro: as Pautas Procedimentais a Serem Respeitadas pelas Agências}

No Brasil, a despeito de diversas leis criadoras das agências reguladoras determinarem que os atos normativos serão precedidos de procedimentos administrativos, conforme visto em item anterior do presente texto, inexiste uma disciplina legislativa uniforme a respeito da matéria, o que implica na existência de procedimentos diferentes em cada agência.

No entanto, levando em consideração as lições doutrinárias, a legitimação pelo procedimento de tais entes administrativos, bem como as limitações materiais que tais atos estão sujeitos - ver item II.C do presente texto -, entendemos possível traçar algumas características gerais que devem estar presentes em ditos procedimentos de expedição de normas regulatórias.

A primeira fase do procedimento é a fase interna de colheita de informações e apontamento pela agência das soluções por ela vislumbradas, na qual o regulador deverá verificar todos os aspectos fáticos, jurídicos, técnicos e econômicos que ensejaram a instauração do procedimento, bem como os reflexos da regulação sobre o subsistema regulado e os demais subsistemas com ele relacionados. Nesta fase, aponta MARÇAL JUSTEN FILHO, a agência deve "determinar o âmbito de abrangência das normas que serão editadas, os problemas a enfrentar, as dificuldades técnico-científicas, as exigências sociais, os recursos econômicos necessários à implementação da solução, os reflexos da regulação (custo regulatório)." ${ }^{228}$, tarefa para a qual pode se socorrer de experts externos, que venham a identificar os problemas e as possíveis soluções que,

\footnotetext{
${ }^{228} \mathrm{O}$ direito das agências reguladoras independentes, cit., p. 567.
} 
nesta fase, são tomadas em caráter eminentemente especulativo, com a apresentação de uma minuta de ato normativo.

Vale notar, que o procedimento administrativo deverá ser instaurado pela agência reguladora, com vistas $\mathrm{a}^{229}$ (i) solucionar um problema concreto, (ii) regulamentar alguma conduta ainda desregulamentada ou inovadora ou (iii) aprimorar a qualidade de alguma prática administrativa já regulamentada, o que demanda da agência uma atuação constante de verificação das suas regras vis-à-vis as finalidades públicas por ela perseguida, com o fim de analisar a necessidade de alteração dos atos normativos vigentes.

Dessa forma, é imprescindível que a agência motive a instauração do procedimento administrativo com a explicitação detalhada da situação de fato que o ensejou, bem como com os estudos técnicos, econômicos e/ou jurídicos que deram azo à necessidade de instaurar o procedimento, tendo em vista que é essencial que os interessados tenham o pleno conhecimento do que se pretende normatizar e de qual a situação atual de referido assunto, para que possam opinar de forma devida e completa no procedimento.

A segunda fase do procedimento é a destinada à manifestação dos interessados na norma regulatória a ser expedida pela agência. Por interessados entendemos aqueles que podem ter seu patrimônio jurídico e econômico atingido pela norma reguladora de forma direta ou indireta. Assim, devem ser ouvidos não apenas os prestadores de serviços do sistema regulado e os usuários efetivos (aqueles que já usufruem do serviço prestado), mas também os candidatos a usuários (aqueles que buscam o serviço já instituído, mediante o preenchimento dos requisitos para a fruição da utilidade), os usuários potenciais (aqueles que podem vir a buscar o serviço, mas ainda não tomaram as medidas necessárias para tanto) $)^{230}$, as organizações da sociedade civil que possam apresentar interesse no tema ${ }^{231}$, bem como, eventualmente, prestadores e usuários (nas

\footnotetext{
${ }^{229}$ JUlianA BONACORSI DE PALMA, Atividade normativa..., cit., p. 381.

${ }^{230}$ A respeito das categorias de usuários - usuários efetivos, candidatos a usuários e usuários potenciais -, cf. CeSAR A. Guimarães PeReIRA, Usuários de serviços públicos: usuários, consumidores e os aspectos econômicos dos serviços públicos, $2^{\mathrm{a}}$ ed., 2008, p. 47-50.

${ }^{231}$ Nesse sentido, cf. MARÇAL JUSTEN FILHO, O direito das agências reguladoras independentes, cit., p. 568.
} 
três categorias) de outros setores que puderem ser atingidos de alguma forma pelo ato normativo regulatório expedido.

Nesta segunda fase, deve-se permitir que os interessados apresentem razões técnicas, jurídicas e econômicas na tutela de seus interesses na norma a ser expedida pela agência. Tal fase é eminentemente uma fase de colheita de provas e elementos fáticos, com a finalidade de subsidiar a agência na emissão da norma regulatória.

$\mathrm{Na}$ terceira fase do procedimento, a agência deverá verificar todas as contribuições feitas pelos administrados, com a finalidade de compila-las e, a partir delas, expedir um esboço da norma regulatória. Tal esboço deverá ser submetido a uma segunda fase de análise pelos interessados, tendo em vista que estes não tiveram a oportunidade de se manifestarem a respeito dos arrazoados e provas fornecidos pelos outros $^{232}$.

Independentemente de haver ou não alteração substancial na minuta apresentada inicialmente para discussão, em virtude das contribuições ofertadas pelos interessados, há a obrigatoriedade da realização de uma segunda rodada de consulta ao público, tendo em vista a necessidade de que os interessados conheçam e se manifestem a respeito das contribuições fornecidas uns pelos outros, ante a possibilidade de conflitos de interesses jurídicos, ainda que de forma indireta, o que implica em respeito ao contraditório e ampla defesa constitucionalmente assegurados (art. $\left.5^{\circ}, \mathrm{LV}, \mathrm{CF}\right)$.

Após a segunda rodada de contribuições, caso não haja mais nenhuma contribuição efetivamente inovadora ou nenhuma outra questão a ser solucionada - o que poderia levar à $3^{\mathrm{a}}$ rodada de contribuições -, a agência deverá emitir o ato normativo regulatório, sempre elaborando motivação racional e de acordo com os elementos do processo ${ }^{233}$.

Contra a decisão do procedimento administrativo, isto é, contra o ato regulatório expedido caberá recurso ou pedido de reconsideração, a depender das normas internas e regimentais da agência reguladora. O importante é que seja ofertada

\footnotetext{
232 JUliana BonaCORSI De PALma, Atividade normativa..., cit., p. 421.

${ }^{233}$ A respeito da motivação, conferir o item II.E do presente capítulo.
} 
aos interessados a possibilidade ofertarem elementos com a finalidade de provocarem a revisão da decisão, como manifestação do contraditório, da ampla defesa e do devido processo legal.

\section{II.C - Os Aspectos Materiais a Serem Analisados na Expedição do Ato Normativo Regulatório}

Vistos os aspectos formais que devem observados pelas agências reguladoras para a expedição dos atos normativos, passamos agora a analisar os aspectos materiais que incidem sobre tal atividade, uma vez que não basta à Administração a realização de um procedimento no qual haja ampla participação dos interessados, pois é necessário que o produto de tal procedimento, a decisão administrativa materializada no ato normativo esteja de acordo com os princípios inerentes ao Estado Democrático de Direito.

Em nosso sentir, dentre todos os princípios a que se submete a Administração, merecem especial destaque a análise dos princípios da eficiência e subsidiariedade, bem como dos postulados da razoabilidade e proporcionalidade, que formam um tripé sobre o qual se apoia a regulação materialmente legítima.

\section{II.C.1 - O Princípio da Subsidiariedade}

O primeiro dos princípios que deve nortear a atividade regulatória de um Estado interventor sobre a economia, e não interventor na economia, é o princípio da subsidiariedade, que se constitui em fórmula contrária à estadualização da vida social $^{234}$.

Tal princípio se estende além dos domínios da intervenção do Estado no domínio econômico, incidindo em todas as formas de atuação estatal, com a finalidade de verificar e sedimentar a competência deste para intervir junto à sociedade, no atual cenário jurídico e social do final do século XX e início do século XXI, que apresenta uma sociedade cada vez mais plural, o que implica na necessidade de um Estado cada vez mais aberto para as demandas e anseios sociais.

\footnotetext{
${ }^{234}$ VITAL MOREIRA, A auto-regulação profissional e a administração pública, 1997, p. 97.
} 
Bem destaca Diogo de Figueiredo Moreira Neto que "[O] debate sobre o Estado não situa tanto, como se possa pensar, sobre o se tamanho, embora seja também um tema relevante, mas principalmente, sobre sua competência, vale dizer, quanto às funções que deve desempenhar para se afirmar como um Estado Instrumental e Competitivo, apropriado a sociedades abertas" ${ }^{235}$.

Dentro desta linha, a atuação do Estado deve se dar de modo subsidiário aos privados, ou seja, o Estado somente deve atuar naquelas situações em que a autorregulação social não seja suficiente para atender aos interesses individuais legítimos presentes na relação por ela regulamentada ${ }^{236}$. Aponta ROBERTO DrOMI ${ }^{237}$ que tal princípio possui uma dupla dimensão: (i) de um lado, impede que o Estado vede os particulares de exercer determinadas atividades de suprimento de necessidades sociais, que possam por eles ser desenvolvidas de modo razoavelmente eficaz; e (ii) demanda que o Estado efetivamente intervenha, de modo subsidiário, naquelas situações em que a sua atuação se mostre imprescindível, na medida em que insuficiente a execução da atividade aos moldes dos particulares para o atingimento do interesse comum. Deste modo, continua o autor argentino, haverá a confluência do estatal e do não estatal na execução de tarefas da gestão pública.

Ainda nessa linha de estabelecimento das premissas do princípio da subsidiariedade, MARIA SYLVIA ZANELLA DI PIETRO ${ }^{238}$ indica três ideias inerentes a ele: (i) a limitação à intervenção estatal, na medida em que a inciativa privada possui primazia em relação ao Estado para a execução de atividades que possam ser desenvolvidas pelos privados por suas próprias iniciativas e recursos; (ii) o Estado deve coordenar, fiscalizar e fomentar a iniciativa privada de modo a permitir aos particulares

\footnotetext{
${ }^{235}$ Mutações do direito administrativo, $3^{\text {a }}$ ed., 2007, p. 123.

${ }^{236}$ A esse respeito, cf. JACQUES CHEVALLIER, O estado..., cit., p. 59-60.

${ }^{237}$ Sistema jurídico e valores administrativos, 2007, p. 224-225. Em brilhante passagem afirma o autor: "Assim, o Estado só intervêm quando o interesse comum o exige por razões lógicas, ontológicas ou teleológicas. Se o ser e o fim do bem público não podem existir nem serem alcançados sem o protagonismo do próprio Estado, sua participação é indiscutível. Do contrário, deve-se entender que a gestão social direta, 'auto-suficiente' e 'auto-satisfatória', é suficientemente eficaz para cobrir necessidades comuns. Isso implica a necessidade de que o Estado se abstenha de atuar quando se atinge a gestão social auto-suficiente". Ob. cit., p. 225-226.

${ }^{238}$ Parcerias na administração pública, $7^{a}$ ed., 2009, p. 15-16.
} 
o sucesso em suas empreitadas; e (iii) estabelecer uma parceria entre o público e o privado, com a finalidade de subsidiar a iniciativa privada para suprir suas deficiências.

No que se refere à aplicação de tal princípio no âmbito das atividades econômicas, ele determina que ao Estado somente é dado intervir em alguma atividade econômica, caso esta não possa ser regulamentada e exercida pelos privados, em regime de liberdade, sem que haja ofensa a direitos constitucionalmente assegurados. De acordo com AlEXANDRE SANTOS DE ARAGÃO, "à medida que os valores sociais constitucionalmente assegurados não sejam prejudicados, o Estado não deve restringir a liberdade dos agentes econômicos, e, caso seja necessário, deve fazê-lo da maneira menos restritiva possível" ${ }^{\text {239. }}$.

Trata-se de princípio intimamente ligado ao da livre iniciativa, previsto no artigo 170, caput, da Constituição Federal, de tal forma que a preferência para a exploração das atividades econômicas deve ser conferida aos particulares, sem a prestação concorrente do Estado, ideia esta que vem reforçada no texto constitucional pelo artigo 173, caput, que determina "Ressalvados os casos previstos nesta Constituição, a exploração direta de atividade econômica pelo Estado só será permitida quando necessária aos imperativos da segurança nacional ou a relevante interesse coletivo, conforme definidos em lei”. Neste sentido, de acordo com MARCOS JURUENA VILlELA SOUTO ${ }^{240}$, o Estado somente pode prestar atividades econômicas quando presentes os requisitos da segurança nacional ou relevante interesse coletivo, que demandem a presença estatal para a universalidade da prestação, o que deverá ser feito sem violar a livre iniciativa.

Logo, o motivo que enseja a atuação estatal é a tutela de interesses públicos, portanto, legítimos e institucionalizados, que não possam ser devidamente atendidos com a simples auto-regulação pelos agentes privados, de tal forma que é incapacidade de atendimento a tais interesses pelos próprios indivíduos que faz surgir a legitimidade para a atuação estatal ${ }^{241}$. Como bem observa Floriano DE AZEVEdo MARQUes Neto:

\footnotetext{
${ }^{239}$ Agências reguladoras..., cit., p. 132.

${ }^{240}$ Direito administrativo regulatório, $2^{\mathrm{a}}$ ed., 2005, p. 224-225.

241 Carlos Eduardo Bergamini Cunha, A subsidiariedade como vetor objetivo de restrição à intervenção regulatória do Estado na economia: definição e instrumentalização, 2013, p. 106-107.
} 


\begin{abstract}
“A atuação do Estado sobre o domínio econômico há de ser residual. Isso não a faz desnecessária ou dispensável. Ela é imperativa sempre que a capacidade dos atores econômicas [sic] ou põe em risco um valor de natureza coletiva (o meio ambiente, o uso de um bem escasso, um serviço de relevância social), ou se mostra insuficiente para se atingir uma finalidade de interesse geral da coletividade (a universalização de um serviço, a acessibilidade de uma comodidade, o incremento da competição, a satisfação das necessidades de usuários de um bem essencial etc.). Apenas existindo uma e outra situação é que se fará cogitável a ação estatal sobre o domínio econômico"242.
\end{abstract}

De acordo com a lição do autor, no que se refere às atividades econômicas, o princípio da subsidiariedade impõe um limite à abrangência da regulação estatal, de tal forma que é com base em tal princípio que se poderá aferir a "legitimidade da submissão de um determinado campo da economia à regulação específica"243, sendo que tal limitação se opera tanto no nível da expedição de atos administrativos pelos entes reguladores, quanto no nível legislativo, de tal modo que "opera mesmo limitando a própria prerrogativa do legislador de constituir campos de incidência específica de regulação estatal, quando isto não seja absolutamente sustentável ao lume dos critérios acima expostos" ${ }^{244}$.

No que se refere à incidência na atividade regulatória, o princípio da subsidiariedade será aplicado, em primeiro lugar, no que se refere à atividade do Legislativo, no sentido de identificar algum setor econômico que demande a intervenção estatal para a tutela dos interesses públicos desatendidos pela auto-regulação privada, com a finalidade de que seja definida a política regulatória setorial.

Tal intervenção é feita de acordo com a presunção de que os atores privados não têm sido capazes de atingir determinadas finalidades sociais ou econômicas, o que demanda a intervenção estatal. "Assim, mesmo em sede de planejamento da atividade regulatória não se pode ignorar o dever de que se demonstrar que (i) a regulação vislumbrada conduzirá a concretização do objetivo almejado e (ii) que o mercado

\footnotetext{
242 Limites à abrangência e à intensidade da regulação estatal. Revista Eletrônica de Direito Administrativo Econômico, no 4, nov/dez 2005, jan/2006, p. 13.

${ }^{243}$ Op. cit., p. cit.

${ }^{244}$ Op. cit., p. cit. Neste ponto, por entendermos que tal princípio possui uma finalidade específica de limitar a abrangência da regulação estatal, divergimos daqueles que defendem ser a subsidiariedade um princípio inserto na proporcionalidade, notadamente no requisito da necessidade deste último princípio, tais como Alexandre Santos de Aragão, Agências reguladoras..., cit., p. 132, e CARLOS EdUARDO BERGAMINI CUNHA, A subsidiariedade..., cit., p. 120-122.
} 
teoricamente não se mostra apto a alcançar tais resultados, justificando, assim, a eventual restrição privada"245.

No que se refere às agências reguladoras, o princípio da subsidiariedade representa limite à intervenção regulatória excessiva, é dizer, à normatização pela agência em questões do setor regulado que possam ser devidamente solucionadas pelos próprios agentes do mercado. Isto não significa ausência de fiscalização ou de atuação das agências reguladoras, mas simplesmente que a normatização de determinado setor regulado somente deve ser realizada com vistas a aqueles direitos que não possam ser atendidos pelas livres regras do mercado.

Em suma, o princípio da subsidiariedade incide na atividade regulatória como elemento de legitimação da atividade reguladora, criando para a iniciativa privada uma garantia de que, se o livre desenvolvimento da atividade for suficiente para tutelar os interesses públicos presentes na atividade, não haverá intervenção estatal sob a forma de regulação da atividade. No entanto, se referidos interesses não forem atendidos pelo livre exercício da atividade, então estará aberto o caminho legítimo para a intervenção estatal por meio da atividade de regulação.

\section{II.C.2 - O Princípio da Eficiência}

Outro princípio de grande relevância para nortear a atividade reguladora do Estado é o princípio da eficiência, introduzido expressamente no artigo 37, caput, da Constituição Federal, pela Emenda Constitucional no 19/98. Antes de tal alteração no Texto Constitucional, no entanto, já era possível verificar a existência de tal princípio de forma implícita, através de dispositivos esparsos ao longo da Lei Maior, tais como os artigos 70, caput, 71, inciso VII, 74, inciso II, e 144, $§ 7^{\mathbf{0} 246}$.

\footnotetext{
${ }^{245}$ A subsidiariedade..., cit., p. 128.

${ }^{246}$ A respeito da presença do princípio da eficiência em tais dispositivos, conferir VERA SCARPINELLA BuENO, As lei de procedimento administrativo: uma leitura operacional do princípio constitucional da eficiência, in Carlos Ari Sundfeld e Guillermo Andrés Muñoz (coords.). As Leis de Processo Administrativo (Lei Federal 9.784/99 e Lei Paulista 10.177/98), 2000, p. 352; PAULO MODESTO, Notas para um debate sobre o princípio da eficiência. Revista Trimestral de Direito Público, vol. 31, 2000, p. 50 .
} 
Trata-se de princípio de difícil conceituação, e mesmo aplicação no Direito. Em primeiro lugar, pois a eficiência é o parâmetro de avaliação da Economia, não do Direito, cujo parâmetro se dá pela legalidade ${ }^{247}$, de tal forma que ao enunciarmos o princípio da eficiência, estamos a enunciar um parâmetro linguístico a priori estranho à esta ciência. Justamente em virtude desta "importação" de um parâmetro de avaliação da Economia, parte da doutrina afirma que a eficiência possui vínculo com a economicidade, de tal forma que a Administração deve operar da melhor forma possível, com o menor custo ao erário ${ }^{248}$.

Em segundo lugar, como nos lembra PAULO MODESTO, o termo eficiência "não é privativo de ciência alguma; é um termo da língua natural, apropriado pelo legislador em sua acepção comum ou com sentido técnico próprio" ${ }^{249}$. Diante de tal característica afirma o autor que os juristas são os "responsáveis diretos pela exploração do conteúdo jurídico desse princípio no contexto do ordenamento jurídico nacional" ${ }^{250}$, o que leva à divergência na doutrina pátria tanto com relação à sua utilidade prática, quanto ao seu conceito jurídico.

Em terceiro lugar, na medida que tal princípio abriga em si um valor que é dos mais corriqueiros na sociedade, visto que nenhuma pessoa em sã consciência atua para ser ineficiente ou cria qualquer coisa para gerar ineficiência - especialmente quando se trata da Administração Pública, que tutela interesses alheios -, além de ser um valor fluido, há doutrinadores que defendem a obsolência de tal princípio. É o caso, por exemplo, de Celso ANTÔNio BANDeIRA DE Mello, para quem trata-se de princípio supérfluo, na medida em que retrata "algo mais do que desejável. Contudo é juridicamente tão fluido e de tão difícil controle ao lume do direito, que mais parece um simples adorno agregado ao art. 37 ou o extravasamento de uma aspiração dos que buliram no texto" ${ }^{\prime 251}$.

\footnotetext{
${ }^{247}$ José Reinaldo de Lima Lopes, Raciocínio jurídico e economia. Revista de Direito Público da Economia, out./dez. 2004, versão digital.

248 Nesse sentido, cf. EDILSON PEREIRA NOBRE JÚNIOR, Administração pública e o princípio constitucional da eficiência. Revista de Direito Administrativo, nº 241, jul./set. 2005, p. 220.

249 Notas para um debate..., cit., p. 49.

${ }^{250}$ Idem, ibidem.

${ }^{251}$ Curso..., $22^{\mathrm{a}}$ ed., 2007, p. 117-118.
} 
No entanto, a despeito de tais críticas e dificuldades conceituais, parece-nos que uma análise mais detida de tal princípio permite chegar a conclusões a respeito de seu conteúdo jurídico.

Uma primeira análise é feita no sentido de não se confundir a eficiência administrativa com a mera eficiência econômica ou com a maximização dos lucros, uma vez que isto, além de não ser "o critério primeiro ou último de uma questão jurídica" 252 , por não lhe dar o sentido a seguir (critério da legalidade/ilegalidade), é antípoda ao Estado Social e Democrático de Direito, que possui em sua base a justiça social e a elaboração de políticas de caráter distributivo, com a finalidade de diminuir as desigualdades sociais ${ }^{253}$. Logo, do ponto de vista jurídico, de nada adianta maximizar lucros ou diminuir a perda de recursos públicos, se isto implicar na sistemática violação a direitos sociais constitucionalmente assegurados.

Assim, por mais que do ponto de vista da eficiência apenas econômica possa ser defensável que o Estado não deva aportar recursos para a área de saúde, com a construção de hospitais, postos de saúde, aquisição de medicamentos, contratação de servidores etc., tal atitude estatal certamente afronta o quanto disposto no art. 196 da Constituição Federal.

Da mesma forma, não vemos a eficiência apenas como alcance das finalidades públicas por meio do menor dispêndio de recursos públicos, ou seja, uma mera questão de custo-benefício econômico, na medida que parece-nos que tal princípio no atual estágio do direito brasileiro envolve a concreção de outros valores, tanto no que se refere à finalidade da atuação estatal, quanto aos meios utilizados pela Administração ${ }^{254}$, o que é acentuado no âmbito da regulação estatal. Aparecem aqui algumas diretrizes a serem seguidas.

A primeira delas se refere à necessidade de que as finalidades normativas sejam alcançadas em seus graus máximos. Neste passo, a eficiência implica no respeito e na observância aos aspectos finalísticos das normas, de tal forma que, conforme

\footnotetext{
252 JOSÉ REINALDO DE LIMA LOPES, Raciocínio jurídico e economia..., cit.

${ }^{253}$ A esse respeito cf. PATRÍCIA PESSÔA VALENTE, Análise de impacto regulatório: uma ferramenta à disposição do Estado, 2013, p. 119.

${ }^{254}$ A esse respeito cf. PAUlo MODESTO, Notas para um debate...cit., p. 54.
} 
ensina AleXAndre Santos de ARAGÃo, "todo ato, normativo ou concreto, só será válido ou validamente aplicado, se, ex vi do Princípio da Eficiência (art. 37, caput, CF), for a maneira mais eficiente ou, na impossibilidade de se definir esta, se for pelo menos uma maneira razoavelmente eficiente de realização dos objetivos fixados pelo ordenamento jurídico" ${ }^{255}$.

Por tal vertente, ainda na linha de referido autor, a eficiência implica numa alteração do modo de se aplicar as leis, não mais se contentando o intérprete/aplicador com a mera subsunção automática, mas sim tendo em vista os objetivos postos em referidos textos normativos e no próprio ordenamento jurídico, o que não implica em descumprimento da lei, mas sim no prestígio primeiro aos seus aspectos finalísticos ${ }^{256}$, o que demanda dos reguladores das atividades econômicas em sentido amplo o conhecimento aprofundado da realidade prática do setor regulado, inclusive no que se refere à permeabilidade de tal setor com os demais setores e subsistemas sociais ${ }^{257}$. Nesse ponto, podemos afirmar que é ínsita à eficiência administrativa a interpretação finalística da norma, não valendo a mera interpretação formal/literal divorciada da finalidade do ordenamento a ser atingida pela concreção normativa.

No entanto, e aqui entramos na segunda diretriz, tal alcance das finalidades do ordenamento jurídico deve obedecer aos limites impostos pelos direitos fundamentais dos cidadãos, de tal modo que a eficiência "relaciona-se não apenas com a finalidade normativa, mas especialmente com o modo de execução de tal finalidade. Em um Estado Democrático de Direito não vale a regra do atingimento da eficácia a qualquer custo, mas é essencial que tal objetivo seja alcançado em respeito ao cidadão" ${ }^{258}$.

Por tal vertente, tem-se que a eficiência deve levar à concreção imediata das finalidades normativas do ato expedido pela Administração, o que caracteriza a eficácia

\footnotetext{
${ }^{255}$ O princípio da eficiência, in Thiago Marrara (org.), Princípios de Direito Administrativo, 2012, p. 378.

${ }^{256}$ É o quanto afirma o Professor da UERJ: "Não se trata de descumprir a lei, mas apenas de, no processo de sua aplicação, prestigiar os seus objetivos maiores em relação à observância pura e simples de suas regras, cuja aplicação pode, em alguns casos concretos, se revelar antitética àqueles. Há uma espécie de hierarquia imprópria entre as meras regras contidas nas leis e os seus objetivos, de forma que a aplicação daqueles só se legitima enquanto constituir meio adequado à realização destes”. (op. cit., p. 379).

257 Idem, p. 380.

258 EGON BOCKMANN MOREIRA, Processo administrativo: princípios constitucionais e a lei 9.784/1999, $4^{\text {a }}$ ed., 2010, p. 207.
} 
administrativa $^{259}$, com a menor restrição aos direitos individuais dos cidadãos, o que implica que a relação custo-benefício seja não apenas econômica, mas também referente aos ônus impostos às liberdades individuais ${ }^{260}$.

A terceira diretriz do princípio da eficiência se liga à necessidade de que ele seja aplicado em conjunto com os demais princípios do ordenamento jurídico, de tal forma que não se poderá considerar eficiente um ato ilegal - ilegalidade aqui considerada sobretudo no seu aspecto finalístico -, imoral, praticado ao arrepio da publicidade etc., em virtude da possibilidade de anulação de tal ato e a necessidade de emissão de novo comando administrativo ${ }^{261}$. A respeito desta terceira vertente, importantes os ensinamentos de EGON BOCKMANN MOREIRA:

\footnotetext{
"Daí por que o princípio constitucional da eficiência pode ser compreendido como a necessidade de o ato administrativo atingir e produzir o efeito útil e adequado, tal como previsto em lei, de forma transparente, moral e impessoal. É o cumprimento da finalidade normativa, adequada a gerar os efeitos esperados pelo ordenamento. Trata-se do contraste entre os resultados atribuíveis à ação administrativa em vista das previsões normativas; relação entre o concretamente realizado e a perspectiva ideal da atividade administrativa",262.
}

Assim, ante esta faceta da eficiência é necessário que a Administração atue de modo a atingir as finalidades do sistema jurídico, notadamente dos direitos e garantias individuais, sem sacrificar os demais princípios inerentes à sua atividade.

Por fim, a quarta diretriz da eficiência se liga à imposição de mais um parâmetro de controle da atividade administrativa, na medida em que, sendo um princípio jurídico, é a eficiência dotada de um conteúdo que se impõe às diversas manifestações estatais, de tal forma que "configura parâmetro de definição da atuação

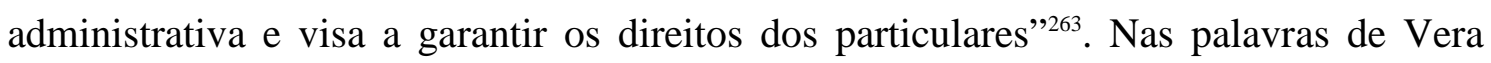
Scarpinella Bueno, "Municia-se o Poder Judiciário com um novo fator de controle da

\footnotetext{
${ }^{259}$ Idem, p. 206.

260 AlEXANDRE SANTOS DE ARAGÃo, O princípio..., cit., p. 375.

${ }^{261}$ EMERSON GABARDO, Princípio constitucional da eficiência administrativa, 2002, p. 97.

${ }^{262}$ Processo administrativo...cit., p. 205-206.

${ }^{263}$ EgOn BocKMann MOREIRA, Processo administrativo..., cit., p. 205. Na mesma linha, cf. EMERSON GABARDO, Princípio constitucional..., cit., p. 96-99.
} 
Administração Pública. Os particulares podem e devem questionar judicialmente a eficiência dos atos administrativos"264.

Nesse passo, sendo a eficiência um princípio a ser seguido pela Administração ele impõe um dever de agir de forma eficiente, de acordo com as quatro diretrizes acima, e evitar que atos ineficientes sejam ou continuem a ser praticados, de modo que a sua positivação no texto constitucional, longe de ser uma inutilidade ou um capricho, significa um importante mecanismo de submissão do agir estatal ao controle de resultados.

Isto não significa dizer que o atingimento da finalidade independe do respeito aos meios legalmente estipulados. O que queremos dizer com tal afirmação desdobra-se em dois pontos que merecem destaque.

Em primeiro lugar, significa que a atividade do controlador não deve se voltar apenas à verificação da correta subsunção da norma ao fato concreto, na medida em que podem ocorrer situações nas quais, a despeito de terem ocorrido eventuais ilegalidades no proceder administrativo, tais ilegalidades foram mínimas, referentes a questões de menor importância, em face do interesse público atingido pelo ato.

Assim, somente será possível a anulação do ato administrativo, caso a ilegalidade praticada tenha violado concretamente outros princípios e regras incidentes sobre no caso, de tal forma que deverá ser demonstrado que a ilegalidade praticada gerou algum prejuízo concreto, não bastando a mera violação ao texto normativo para gerar a invalidação do ato e/ou a aplicação da correspondente sanção ao servidor envolvido.

Em segundo lugar, e até mais importante do que o primeiro aspecto apontado, a atividade do controlador não pode inviabilizar os benefícios gerados à coletividade pelo ato tido como ilegal, de tal forma que a ilegalidade praticada pela Administração não pode ser o único supedâneo para a determinação da nulidade do ato e suspensão de todos os seus efeitos. A isto retornaremos no capítulo III.

${ }^{264}$ As leis de procedimento..., cit., p. 356. 
No âmbito das atividades econômicas em sentido amplo, isto significa que a regulação estatal deve ser exercida por meio de medidas que possuam a menor ingerência possível no desenvolvimento das empresas e dos atores do setor regulado, de tal forma que a expedição do ato regulatório corresponda "à escolha de medidas regulatórias cujos benefícios, se não superem, pelo menos justifiquem os custos a serem incorridos pelo Estado, pelo mercado regulado, pelos usuários de bens e serviços desse mercado e pela sociedade em geral" ${ }^{\prime 265}$.

Ainda no que se refere à eficiência na atividade de regulação, mostra-se imprescindível que as medidas regulatórias sejam tomadas de acordo com os objetivos setoriais determinados pelas leis das agências reguladoras, em virtude da perspectiva finalística de referida legislação ${ }^{266}$, de tal modo que a eficiência será atingida se respeitados os objetivos setoriais legalmente estabelecidos.

\section{II.C.3 - Os Princípios da Razoabilidade e da Proporcionalidade}

Juntamente com os princípios acima mencionados, a atividade normativa das agências reguladoras deve observar os princípios da razoabilidade e da proporcionalidade.

Antes de aprofundar o estudo a respeito de cada um destes princípios, importante anotar que os consideramos como princípios autônomos, por possuírem características, funções e requisitos próprios, que não permitem que sejam intercambiáveis os termos razoabilidade e proporcionalidade ${ }^{267}$.

\footnotetext{
${ }^{265}$ PATRícia Pessôa VALENTE, Análise de impacto regulatório..., cit., p. 111.

${ }^{266}$ TÉRCIO SAMPAIO FERRAZ JÚNIOR, Agências reguladoras..., cit., p. 157.

${ }^{267}$ Fazemos tal observação, uma vez que há intensa divergência doutrinária a respeito da identidade ou não entre os postulados da razoabilidade e da proporcionalidade - tratados por muitos autores como princípios. Nesse passo, na corrente que defende serem princípios equivalentes, destacam-se LUIS RoBerto BARroso (Curso..., cit., p.257-258), José RoBERTO PIMENTA OlIVEIRA (Os princípios da razoabilidade e da proporcionalidade no direito administrativo brasileiro, 2006, p. 192 e segs.) e MARIA SYlVIA ZANELla Di PIETRO (Discricionariedade..., cit., p.191). Para tais autores, tais princípios são idênticos, correspondendo a exigências impostas à Administração, como forma de limitação à edição de atos administrativos e legislativos, diferenciando-se, apenas, em razão da origem da razoabilidade achar-se no Direito Anglo-Saxão e a da proporcionalidade estar no Direito Alemão. Segundo JoSÉ ROBERTO PIMENTA OLIVEIRA, a proporcionalidade é uma faceta da razoabilidade, que permite o controle desse princípio pelos critérios da adequação, necessidade e proporcionalidade em sentido estrito (ob. cit., p. 189-190). Segue o autor ao afirmar: "Entende-se que o desenvolvimento conceitual do princípio da proporcionalidade, nos sistemas de civil law, fornece apenas um dos critérios técnico-jurídicos aptos a dar
} 
Com efeito, conforme será demonstrado, a razoabilidade possui como função a análise de dois vetores da atuação estatal: (i) a verificação da equidade da medida adotada, o que implica na análise do enquadramento ou não de dada situação concreta na hipótese e na finalidade da norma em princípio aplicável; e (ii) a correlação entre critério e medida, ou seja, a verificação da existência de congruência e de equivalência entre aquilo que gerou a atuação estatal (critério) e a atuação in concreto (a medida).

A proporcionalidade, por sua vez, possui por objeto de análise a relação entre o meio empregado pelo Estado na sua atuação e o fim por ele visado, na busca pela existência de causalidade entre elas, ou seja, se adotando-se o meio utilizado chega-se ao fim visado, o que é feito pela utilização de três critérios inerentes ao exame da proporcionalidade: a necessidade, a adequação e a proporcionalidade em sentido estrito.

Outra distinção que pode ser levantada se refere ao fato de que a análise da razoabilidade é feita dentro do próprio ato, sem a necessidade de haver um elemento de comparação, tendo em vista que a "razoabilidade se liga à adstrição da atividade estatal a um nexo lógico, ao juízo de plausibilidade em si. Trata-se, portanto, de uma restrição ao excesso em face da lei e em face dos standards genericamente admitidos pela comunidade num dado momento" ${ }^{268}$. A proporcionalidade, por sua vez, é verificada sempre em comparação com outra medida, uma vez que "algo somente poderá ser desproporcional em relação a outra alternativa possível”269.

ensejo ao controle de razoabilidade das decisões administrativas. Este controle necessariamente é dinâmico,seja em sua aplicação, seja mesmo em sua formulação. Abarca, por exemplo, as injunções impostas pela ponderação de interesses, se conceitualmente diferenciada da máxima da proporcionalidade, bem como as inferências derivadas o mandamento da boa-fé objetiva no tráfego jurídico-administrativo." (ob. cit., p. 197). Na linha dos que defendem a diferenca entre os princípios da razoabilidade e da proporcionalidade, a qual nos filiamos, podemos destacar CELSO ANTÔNIO BANDEIRA DE Mello (Curso..., cit., p. 114-115), Humberto Bergmann Ávila (Teoria..., cit., p. 163 e segs.), CARlos Roberto SiQueira CASTro (O devido processo legal..., cit., p. 145 e segs.), Floriano DE AZEVEDo MARQUes Neto (Limites..., cit.) e Luís Virgílio AFOnSO DA Silva, que afirma: “A regra da proporcionalidade no controle das leis restritivas de direitos fundamentais surgiu por desenvolvimento jurisprudencial do Tribunal Constitucional alemão e não é uma simples pauta que, vagamente, sugere que os atos estatais devem ser razoáveis, nem uma simples análise da relação meio-fim. Na forma desenvolvida pela jurisprudência constitucional alemã, tem ela uma estrutura racionalmente definida, com subelementos independentes - a análise da adequação, da necessidade e da proporcionalidade em sentido estrito -, que são aplicados em uma ordem pré-definida, e que conferem à regra da proporcionalidade a individualidade que a diferencia, claramente, da mera exigência de razoabilidade." (O proporcional e o razoável, Revista dos Tribunais, n 798, abr./2002, p. 30-31).

${ }^{268}$ FloRIANO DE AZEVEDO MARQUES Neto, Limites..., cit., p. 17.

${ }^{269}$ Idem, ibidem. 
Ainda no caráter introdutório de tais princípios, importante diferenciá-los do princípio da subsidiariedade, que também impõe um limite negativo à atividade normativa reguladora. A subsidiariedade implicará na limitação às áreas nas quais o regulador poderá normatizar o setor regulado, devendo ser respeitada a livre iniciativa e as regras de livre mercado, sempre que elas se mostrarem aptas a garantir as finalidades do setor regulado e tutelar os direitos envolvidos.

A proporcionalidade e a razoabilidade, de outro lado, possuem por função analisar a intensidade da medida regulatória, com a finalidade de evitar que sejam impostas restrições excessivas aos agentes do setor regulados, tendo em vista as finalidades de tal segmento do mercado ${ }^{270}$.

Com efeito, possuindo a atividade regulatória caráter restritivo à livre iniciativa, é necessário que a intervenção estatal ocorra na menor medida necessária para o atingimento das finalidades do setor regulado, de tal forma que a proporcionalidade representa importante elemento para aferir se a normatização regulatória exorbitou o quanto necessário à consecução de tais finalidades. Logo, a análise de tais princípios não deve ser feita de acordo com ideias teóricas e conforme aquilo que o intérprete entende como razoável ou proporcional, mas sim de acordo com as finalidades do setor regulado.

Feitas estas considerações, passamos a analisar os princípios em apreço.

\section{II.C.3.1 - O Princípio da Razoabilidade}

O princípio da razoabilidade tem origem no direito anglo-saxão, na cláusula law of tha land, da Magna Carta de 1.215 assinada por João "Sem Terra". Segundo tal regra, inscrita no art. 39 de tal Texto Maior $^{271}$, que determinava que os barões somente poderiam ser julgados pela "Lei da Terra", imposta a todos, e não segundo as penalidades impostas pelo Rei, caso a caso.

\footnotetext{
${ }^{270}$ Idem, p. 19.

${ }^{271}$ Art. 39. "Nenhum homem será preso ou detido em prisão ou privado de suas terras ou posto fora da lei ou banido ou de qualquer maneira molestado; e não procederemos contra ele nem o faremos vir a menos que por julgamento legítimo de seus pares ou pela lei da terra”.
} 
Tal garantia foi a precursora da cláusula do devido processo legal (due process of law), que apareceu em emenda feita por Eduardo III no ano de $1.354^{272}$ e consolidouse nas $5^{\mathrm{a} 273}$ e $14^{\mathrm{a} 274}$ Emendas à Constituição norte-americana, "de onde se irradiou como um dos mais ricos fundamentos da jurisprudência da Suprema Corte" ${ }^{275}$.

Em um primeiro momento, o devido processo legal somente possuía caráter processual (procedural due process), voltando-se, à primeira vista, ao processo penal e, depois, aos processos civil e administrativo. Sua aplicação garantia às partes (a) o contraditório e a ampla defesa, (b) o juiz natural, (c) a proibição de utilização de provas obtidas por meio ilícito, (d) o direito de não ser preso senão a mando da autoridade competente e de acordo com as regras postas no ordenamento jurídico ${ }^{276}$, (e) assistência judiciária, (f) duplo grau de jurisdição, (g) publicidade das audiências ${ }^{277}$ etc.

Após a afirmação de diversas garantias de ordem processual, a jurisprudência norte-americana passou a entender que a cláusula do devido processo legal também continha em si a garantia de razoabilidade dos atos normativos dos Estados Unidos.

Conforme anota CHRISTOPHER WOLFE ${ }^{278}$, tal controle de razoabilidade possuía dois fundamentos: o primeiro se baseava na noção de que há um direito natural de justiça e deve nortear as soluções das controvérsias jurídicas. O segundo argumento se refere à determinação de que a própria 'lei' guarda em si uma garantia contra o abuso e as atitudes desarrazoadas.

\footnotetext{
${ }^{272}$ CHRISTOPHER WOLFE, The rise of modern judicial review, p. 134.

273 "Nenhuma pessoa será levada a responder por crime capital, ou de outro modo infamante, a não ser por declarações sob juramento ou acusação formal de um júri de instrução, exceto em casos surgidos nas forças terrestres ou navais, ou na milícia, quando em serviço em tempo de guerra ou de perigo público; da mesma forma, nenhuma pessoa estará sujeita, pelo mesmo crime, a correr por duas vezes perigo de vida; nem será obrigada, em nenhum caso criminal, a depor contra si mesma, nem será privada da vida, liberdade ou propriedade, sem o devido processo legal; nem a propriedade privada será desapropriada para uso público sem justa compensação". (g.n.)

274 "Todas as pessoas nascidas ou naturalizadas nos Estados Unidos e sujeitas à sua jurisdição são cidadãos dos Estados Unidos e dos Estados onde residem. Nenhum Estado editará ou aplicará qualquer lei que prejudique os privilégios e imunidades dos cidadãos americanos; também nenhum Estado privará qualquer pessoa de sua vida, liberdade ou propriedade sem o devido processo legal, nem negará a qualquer pessoa dentro de sua jurisdição a igual proteção da lei”. (g.n.)

${ }^{275}$ LUIS ROBERTO BARROSO, Curso...,cit., p. 256.

${ }^{276}$ Itens 'a', 'b', 'c', e 'd', cf.: GILMAR FERREIRA MENDES et alli., Curso...cit., p. 603.

${ }^{277}$ Itens 'e', 'f' e 'g', cf.: MARIA SYLVIA ZANELlA DI PIETRO, Discricionariedade..., cit., p. 186.

${ }^{278}$ The rise..., p. 145 .
} 
Nesse período, conhecido como governo dos juízes, a cláusula ganha seu contorno substantivo (substantive due process), caracterizando-se como verdadeira garantia do cidadão em face de atos normativos ${ }^{279}$ desarrazoados, que não guardassem relação entre os meios utilizados e a finalidade da norma.

Nesse período, "o Judiciário passou a desempenhar determinados controles de mérito sobre o exercício de discricionariedade pelo legislador, tornando-se importante instrumento de defesa dos direitos fundamentais - especialmente da liberdade e da propriedade - em face do poder político. O fundamento de tais controles assentava-se na verificação da compatibilidade entre o meio empregado e pelo legislador e os fins visados, bem como na aferição da legitimidade dos fins. Por intermédio da cláusula do devido processo legal passou-se a proceder ao exame da razoabilidade (reasonablesness) e da racionalidade (rationality) das leis e dos atos normativos em geral do direito norte-americano" 280 .

O devido processo legal substantivo ganha relevância como forma de se garantir a livre iniciativa e a propriedade privada dos cidadãos e das empresas, como forma de evitar que o police power impusesse medidas por demais restritivas a esses valores típicos do capitalismo. Nesse período, fins do século XIX, a cláusula do devido processo legal foi muito desenvolvida como forma de contrabalançar os direitos das empresas, prestadora, ou não, de serviços públicos, e os de seus empregados ${ }^{281} \mathrm{e}$ usuários de serviços públicos, que tinham garantias estipuladas pelas leis dos Estados americanos.

\footnotetext{
${ }^{279}$ Legislativos ou administrativos, uma vez que, nos Estados Unidos, a Administração possui função legislativa delegada pelo Poder Legislativo. Cf.: MARIA SYlvia ZANella DI PIETRO, Discricionariedade..., cit., p. 187.

${ }^{280}$ Luis Roberto Barroso, Curso..., cit., p. 256.

${ }^{281}$ Com relação ao conflito entre a legislação trabalhista, que garantia direitos dos empregados, em face da livre iniciativa das empresas, a jurisprudência norte-americana aplicou a razoabilidade para permitir que os salários das mulheres fossem proporcionais ao trabalho realizado, e não apenas ao necessário para suprir as necessidades femininas, conforme Adkins v. Children's Hospital (1923). No caso Lochner v. New York, houve análise de razoabilidade em lei que limitou o trabalho dos padeiros em 10 horas por dia e 60 horas por semana. Tal lei foi considerada desarrazoada, por não haver relação de razoabilidade entre a finalidade, proteção da saúde dos padeiros e o meio utilizado, limitação da jornada, que acaba por limitar a livre iniciativa. Por outro lado, no caso Holden v. Hardy, a Corte entendeu por validar norma que limitava a jornada de trabalho dos mineradores, por entender haver relação entre a finalidade, proteção da saúde dos mineradores, e o mio utilizado, a redução da jornada de trabalho. A respeito desses precedentes, conferir CHRISTOPHER WOLFE, The rise..., cit., p. 151.
} 
Com relação à regulação tarifária, a cláusula aqui estudada foi utilizada pelas Cortes, com a finalidade de estipular tarifas $\underline{\text { razoáveis }}$, que "conciliassem, de um lado, o interesse das empresas - que devem ser remuneradas de forma justa, para que possam manter seu equilíbrio econômico-financeiro - e, de outro lado, o interesse do usuário, que faz jus a serviços adequados, mediante tarifas satisfatórias" 282 .

Com o avançar do tempo, a razoabilidade passou a ganhar diferentes contornos, de acordo com os diversos doutrinadores que abordaram o tema, sendo considerada como vedação ao arbítrio, como exigência de justiça, como standard jurídico, como exigência de bom senso e sensatez na atuação administrativa, como dever de racionalidade, como imposição de proporcionalidade, como mandamento de ponderação e como parâmetro de interpretação ${ }^{283}$.

De nossa parte, conforme já mencionado, a razoabilidade é um princípios que possui por finalidade evitar o abuso por parte do Estado, seja ele o EstadoAdministração, Estado-Legislador ou o Estado-Juiz. Dentre as acepções que podem servir de análise da razoabilidade, ganham relevo três tipologias destacadas por HUMBERTO BERGMANN ÁvILA ${ }^{284}$.

A primeira delas é a da razoabilidade enquanto equidade, que exige a harmonização da norma geral com o caso individual. Nesse passo, a razoabilidade impõe que o intérprete analise a aplicação da norma de acordo com as peculiaridades do caso concreto, o que poderá levar, inclusive, ao afastamento da aplicação da norma, diante da existência de caso anormal. Trata-se, aqui de verificar se, diante das especificidades do caso, não ocorreu algum caso excepcional inviabilizador da aplicação da norma que parece incidente. Em outras palavras, trata-se de considerar as condições individuais do caso, que não foram sopesadas pelo legislador quando da

\footnotetext{
${ }^{282}$ MARIa SYlVIa Zanella Di PIETRO, Discricionariedade..., cit., p. 186-187. Como exemplos de casos nos quais o substantive due process foi utilizado como forma de garantir a livre iniciativa, inclusive através da garantia de taxas justas para remunerar as empresas, pode-se citar os seguintes precedentes da Suprema Corte Americana, que são trazido por ChristoPHER WOLFE (The rise..., cit., p. 149-152): Chicago, Milwaukee and St. Paul Railroad v. Minnesota (1890), considerado o primeiro caso de aplicação do devido processo legal substantivo; Allgeyer v. Louisiana (1897); Smyth v. Ames (1898); Munn v Illinois; Adams v. Tanner (1917); Wolff Packing Co. v. Court of Industrial Relations (1923); Tyson and Bros. v. Banton (1927); New State Ice Co. v. Liebmann (1932).

${ }^{283}$ A respeito das diversas abordagens da razoabilidade, cf. José ROBERTO Pimenta Oliveira, Os princípios..., cit., p. 150-163.

${ }^{284}$ Teoria..., cit., p. 164-172.
} 
instituição da regra, de acordo com a equidade. Com efeito, "Uma regra não é aplicável somente porque as condições previstas em sua hipótese são satisfeitas. Uma regra é aplicável a um caso se, e somente se, suas condições são satisfeitas e sua aplicação não é excluída pela razão motivadora da própria regra ou pela existência de um princípio que institua uma razão contrária. Nessas hipóteses as condições de aplicação da regra são satisfeitas, mas a regra, mesmo assim, não é aplicada" ${ }^{285}$.

A segunda tipologia se refere à razoabilidade enquanto congruência, o que exige a existência de harmonização do conteúdo da norma com as condições externas de aplicação. Integra tal tipologia a análise da existência ou da suficiência do contexto fático para a atuação estatal, de tal modo que o Estado somente pode atuar se houver suporte fático para tanto e, mais do que isto, se tal suporte se mostrar suficiente para o agir estatal, o que implica na vedação às razões arbitrárias e no impedimento à subversão dos procedimentos institucionais para a consecução dos fins almejados. Além disto, em tal tipologia se encontra a necessidade de congruência entre o critério de diferenciação escolhido e a medida adotada, com a finalidade de evitar desequiparações desarrazoadas, no sentido de elegerem um critério antijurídico ou se valerem de uma medida ilegal para tanto.

$\mathrm{Na}$ terceira tipologia, analisa-se a razoabilidade enquanto equivalência entre uma medida adotada e o critério que a dimensiona, com a finalidade de verificar se existe razão entre elas. Como exemplos, podemos mencionar a análise da penalidade a ser aplicada, que deve levar em conta a culpabilidade do agente; a atipicidade da conduta delitiva pela insignificância do bem jurídico atingido; ou mesmo a íntima relação que deve existir entre o valor da taxa cobrada o serviço prestado.

De acordo com tais tipologias, portanto, é possível analisar a legitimidade da medida estatal adotada, o que implica na possibilidade de submissão ao controle judicial dos atos legislativos e administrativos - aqui incluídos os normativos - que não se atentarem para o respeito à relação critério-medida que deve nortear a atuação estatal. A tal ponto retornaremos no capítulo seguinte, mas deixamos claro desde logo que o postulado da razoabilidade implica na ampliação dos parâmetros de juridicidade do agir

${ }^{285}$ Humberto Bergamnn Ávila, Teoria..., cit., p. 166-167. 
administrativo - até porque é pauta de verificação de como foram aplicados os princípios e regras incidentes no caso - e, portanto, implica na elasticidade dos limites do controle judicial da Administração.

\section{II.C.3.2 - O Princípio da Proporcionalidade}

O princípio da proporcionalidade tem origem no direito alemão, utilizado, em primeiro lugar, para realizar o controle de atos administrativos ${ }^{286}$, e, após a Segunda Guerra, das leis, ambos restritivos de direitos fundamentais ${ }^{287}$, com a finalidade de analisar a existência de correlação entre os meios empregados e os fins almejados, tendo em vista os direitos fundamentais objeto de restrição.

Assim, o exame da proporcionalidade possui aplicabilidade restrita àquelas situações nas quais exista uma medida concreta destinada à realização de um fim, de tal forma que se traduz, na linha de CARlos Roberto Siqueira CASTRO, em "orientação deontológica de se buscar o meio mais idôneo, mais eqüitativo e menos excessivo nas variadas formulações do Direito, seja na via legislação ou da positivação das normas jurídica, da administração pública dos interesses sociais, da aplicação judicial dos comandos normativos" 288 .

Ainda de acordo com referido autor, importante destacar que a aplicação do postulado da proporcionalidade (por ele chamado de princípio) não deve ser feita a todo e qualquer conflito de interesses, tendo em vista que isto "seria uma hipertrofia do princípio, uma prodigalização indevida de suas premissas, além de uma utilização desmesurada de suas virtualidades, em situações que apresentem outros contornos que não a análise comparativa de custo/benefício ou de congruência entre meios-fins", o que implicaria em "transformar o postulado em autêntica panaceia para remediar todos os males jurídicos, com isso desacreditando-o" 289 .

\footnotetext{
${ }^{286}$ Luís Roberto Barroso, Curso..., cit., p. 258; Paulo Bonavides, Curso de direito constitucional, $23^{\mathrm{a}}$ ed, 2008, p. 407.

${ }^{287}$ LUÍs VIRGílio AfONSO DA Silva, O proporcional e o razoável..., cit., p. 30. No mesmo sentido, GILMAR FerReIRA MENDES e outros, Curso..., cit., p. 311 e segs.

${ }^{288}$ O devido processo legal..., cit., p. 199.

${ }^{289}$ Op. cit., p 209.
} 
A análise da proporcionalidade de uma medida demanda a realização do exame de três critérios essenciais para a aferição da proporcionalidade de uma medida: a adequação, a necessidade e a proporcionalidade em sentido estrito. Passemos a analisar cada uma delas.

\section{II.C.3.2.1 - Adequação}

Pelo exame da adequação, deve-se analisar se o meio empregado pelo agente conduz ao fim almejado, ou seja, "o meio deve levar à realização do fim. Isso exige que o administrador utilize um meio cuja eficácia (e não o meio, ele próprio) possa contribuir para a promoção gradual do fim" ${ }^{290}$.

Importante mencionar, neste sentido, que o dever imposto ao administrador de observar a exigência de adequação da medida adotada não implica na imposição de que ele adote a melhor, o mais intenso e o mais seguro meio para atingir determinado fim, bastando que adote um meio que simplesmente, minimamente, promova o fim almejado, tendo em vista que ${ }^{291}$ : (i) nem sempre é possível à Administração saber, dentre diversos meios possíveis, qual o melhor, mais seguro e mais intenso para a promoção de determinado fim; e (ii) pela separação de funções, é necessário que haja um mínimo de liberdade de atuação aos agentes públicos, de tal forma que é inerente ao exercício da função administrativa a possibilidade de escolha de um dentre vários meios possíveis para o alcance de dado fim.

Ademais, a verificação a respeito da adequação da medida deve ser feita com relação ao momento no qual foi tomada a decisão pelo administrador, levando-se em consideração as informações e as circunstâncias existentes naquele momento, e não no momento posterior, no qual o julgador avalia a proporcionalidade/desproporcionalidade da medida adotada. Tal necessidade de o controlador realizar uma análise retrospectiva da adoção da medida adotada pelo agente se deve ao fato de que "o exame da proporcionalidade exige do aplicador [administrador] uma análise em que preponderam os juízos do tipo probabilístico e indutivo" ${ }^{292}$, de tal forma que o julgador, se for analisar

\footnotetext{
${ }^{290}$ Humberto Bergmann Ávila, Teoria..., cit., p. 177.

291 Idem, p. 178.

292 Idem, p. 180.
} 
a situação apenas com vistas ao panorama ex post terá uma visão diversa daquela que o administrador teve ao exarar o ato, prejudicando a atividade de controle, pois esta partirá de pressuposto fático diverso, não presente à época da expedição do ato.

\section{II.C.3.2.2 - Necessidade}

O exame da necessidade possui como objetivo analisar se não existiria outro meio menos restritivo aos direitos dos particulares envolvidos e igualmente eficaz para o atingimento da finalidade almejada. Assim, o exame da necessidade passa por uma dupla verificação ${ }^{293}$ : (i) em primeiro plano, deve-se analisar a igualdade de adequação dos meios, com a finalidade de verificar se os meios não adotados pela Administração (meios alternativos) promoveriam igualmente o fim perseguido, ou seja, se a alteração do meio não implica em alteração da promoção do fim; (ii) em segundo lugar, deve-se verificar se os meios não adotados (alternativos) restringiriam em menor medida os direitos fundamentais afetados pela medida estatal adotada. Em síntese, "um ato estatal que limite direito fundamental somente é necessário caso a realização do objetivo perseguido não possa ser promovida, com a mesma intensidade, por meio de outro ato que limite, em menor medida, o direito fundamental atingido" 294.

Tal análise se mostra problemática, uma vez que a verificação da existência de medida alternativa igualmente eficaz para o atingimento do fim almejado, mas, ao mesmo tempo, menos restritiva a direitos fundamentais implica na verificação de hipóteses que não ocorreram no caso em análise, de modo que corre-se o risco de substituição da escolha administrativa pela suposição judicial.

Diante disto, é necessário que se verifique as peculiaridades do caso concreto, conforme a lição de JOSÉ ROBERTO PIMENTA OLIVEIRA: "Na aferição in concreto da necessidade da medida, sobressai a dificuldade de sua configuração e controle em razão das peculiaridades de cada caso apreciado. Deve-se levar na devida conta todos os efeitos provocados pelas medidas em comparação, inclusive efeitos secundários eventualmente deflagráveis com sua adoção" ${ }^{295}$.

\footnotetext{
${ }^{293}$ Humberto Bergmann Ávila, Teoria..., cit., p. 182.

${ }^{294}$ LUÍS VIRGÍlIO AFONSO DA SILVA, O proporcional e o razoável..., cit., p. 38.

${ }^{295}$ Os princípios..., cit., p. 54.
} 
Não obstante, o controle a ser exercido com base na necessidade deve ser um controle residual, ou seja, deve ser respeitada a escolha feita pelo administrador institucionalmente competente para tomar a medida, com o afastamento do meio somente se ele for manifestamente menos adequado que outro ${ }^{296}$.

\section{II.C.3.2.3 - Proporcionalidade em Sentido Estrito}

Pelo exame da proporcionalidade em sentido estrito verifica-se se a realização do fim é proporcional à intensidade da restrição aos direitos fundamentais envolvidos. Como bem pontua Humberto Ávila, tal exame possui a finalidade de responder às seguintes indagações: “As vantagens causadas pela promoção do fim são proporcionais às desvantagens causadas pela adoção do meio? A valia da promoção do fim corresponde à desvalia da restrição causada?" ${ }^{297}$.

Tal exame possui como objetivo verificar a relação custo-benefício da medida, através da verificação do benefício gerado para a coletividade com a atuação administrativa e a restrição aos direitos fundamentais subjacentes ao caso em análise. Nas palavras de CARlos Roberto Siqueira CAStro, busca-se "aferir se foi observada a necessária relação de congruência, de suficiência, de intensidade e de adequada correlação entre a restrição instituída pelo Poder Público e os benefícios coletivos alcançáveis com medida interventiva na esfera de autonomias privadas"298.

\section{II.D - A Discricionariedade na Atividade Normativa Regulatória}

\section{II.D.1 - Fundamento da Discricionariedade e Delineamentos Gerais}

No Estado de Direito, a atuação da Administração Pública está intimamente ligada ao direito - aqui entendido não apenas como a lei em sentido estrito, mas a todo o ordenamento, o que também inclui os princípios jurídicos -, de tal forma que o agir

\footnotetext{
${ }^{296}$ Humberto Bergmann Ávila, Teoria..., cit., p. 183.

${ }^{297}$ Op. cit., p. 185.

${ }^{298}$ O devido processo..., cit., p. 217.
} 
administrativo deve se dar nos limites permitidos pelo ordenamento, que é, ao mesmo tempo, elemento de autorização e condicionante da atuação estatal ${ }^{299}$.

Tal regramento do agir estatal possui sua razão de ser na contenção do poder, com a finalidade de evitar o arbítrio estatal, ou seja, a atuação livre e desimpedida do administrador de acordo com seus interesses e vontades. Assim, é necessário que haja alguma forma de autorizamento da ação estatal no ordenamento jurídico, sob pena de o agir administrativo ser considerado ilegal. No entanto, por mais que o ordenamento jurídico seja fruto, ao menos em nível primário e inaugural, das atividades do constituinte e do Legislativo, afinal é na Constituição e nas leis que se encontram as competências dos entes e agentes estatais, a atuação da Administração não pode ser prevista em suas minucias pelos atos gerais e abstratos do Legislativo.

Em virtude desta limitação material do legislador, o próprio ordenamento concede ao administrador a competência para, em determinadas situações, previamente estipuladas em lei, optar se e como agir, com a finalidade de atingir de forma óptima a finalidade pública disposta na lei.

Figura capital do direito administrativo, a discricionariedade representa, como bem nos lembra CHARLES EISENMANN ${ }^{300}$, um fenômeno um tanto misterioso, inquietante, na medida em que demonstra uma contradição latente entre a ideia de que a Administração Pública integra o Executivo, que tem por missão assegurar a execução da lei - produto do Legislativo -, e a característica da discricionariedade que concede ao agente um campo de escolha para atuação. Diante disto, lembra o autor francês que a discricionariedade é objeto que apresenta necessidade constante de justificação. Na

\footnotetext{
${ }^{299}$ A esse respeito, importantes as considerações de EDUARDO GARCÍA DE ENTERRíA e TOMÁS-RAMÓN FERNÁNDEZ: "Los actos y las disposiciones de la Administración, todo, han de <<someterse a Derecho〉>, han de ser <<conformes〉> a Derecho. El desajuste, la desconformidad, constituyen < infracción del Ordenamiento jurídico〉> y lês priva a actual o potencialmente (distinción entre nulidad y anulabilidad), de validez. El Derecho no es, pues, para la Administración una linde externa que señale hacia fuera una zona de prohibición y dentro de la qual pueda ella producirse com su sola libertad y arbitrio. Por el contrario, el Derecho condiciona y determina, de manera positiva, la acción administrativa, la cual no es válida se no responde a uma previsión normativa. (...) El principio de legalidad de la Administración opera, pues, en la forma de uma cobertura legal de toda la actuación administrativa: sólo cuando la administración cuenta com esa cobertura legal previa su actuación es legítima". (Curso de derecho administrativo, vol. I, $13^{\mathrm{a}}$ ed., 2006, p. 446).

${ }^{300}$ Cours de droit administratif, tomo II, 2014 [reimp. da edição de 1983], p. 289-290
} 
busca, então, por justificar a existência da discricionariedade administrativa, a doutrina aponta os fundamentos de tal competência concedida pela própria lei à Administração.

Em nosso sentir, a despeito de reconhecermos a inexistência de uma nominação unívoca na doutrina a respeito do tema ${ }^{301}$, é possível vislumbrar três fundamentos para a existência da discricionariedade administrativa: o fundamento prático, o fundamento político e o fundamento institucional.

Do ponto de vista prático, a discricionariedade administrativa se fundamenta no fato de ser impossível ao legislador prever de antemão todas as situações que demandarão a atuação da Administração, bem como todas as soluções a serem tomadas pelo administrador na consecução da finalidade pública que demanda a intervenção estatal.

Nesse passo, o estabelecimento prévio de todas as situações de atuação e das correspondentes soluções jurídicas a serem adotadas implicaria em manifesto engessamento da Administração Pública, levando justamente ao resultado contrário da finalidade de sua atuação: ao invés de agir para viabilizar a consecução dos interesses públicos, a atuação administrativa implicaria em afronta a estes, na medida em que tiraria do administrador a possibilidade de valorar situações e conceder a solução que melhor atendesse a tais interesses em prol da coletividade ${ }^{302}$.

Com efeito, conforme pontifica RAFAEL BIELSA, administrar é mais do que simplesmente executar, uma vez que se este é cumprir o que fora ordenado, administrar significa conceber e colocar em prática tal concepção, com critérios de oportunidade, eleição de meios, economia, maior eficiência etc., de tal forma que a discricionariedade é ínsita à noção de administrar. Nas palavras do autor:

“a Lei não pode prever todas as situações que irão se apresentar ao Poder Administrativo; ela, em geral, assinala regras ou normas relativas à competência e às atribuições dos órgãos administrativos, mas não pode prever hipóteses muito circunstanciais, fatos ou fatos complexos. Por isso, que atribui ao Poder administrativo certa faculdade discricionária. Logo, é da natureza do exercício de

\footnotetext{
${ }^{301}$ A respeito das diferentes nomenclaturas da classificação da discricionariedade, cf., por exemplo, LUIS MANUEl Fonseca PIRES (Controle judicial..., cit., p. 156-157) e MARIA SYlvia ZANELla Di PIETRO (Discricionariedade..., $3^{\mathrm{a}}$ ed., p. 62-66).

302 Nessa linha, cf. Celso ANTÔNIO BANDEIRA DE Mello, Curso..., cit., p. 981-982.
} 
todo poder - e especialmente do Poder administrativo - exercitar discricionariamente atribuições próprias" ${ }^{303}$.

Justamente por essa razão que o legislador, quando entende que a finalidade pública subjacente à lei que produz será melhor atendido pelo administrador, diante do caso concreto e dos fatos levados à sua consideração, estipula a discricionariedade para que este tenha margem de apreciação e decisão a respeito da melhor atuação em vista de referida finalidade pública ${ }^{304}$.

Notadamente em uma sociedade complexa, com diversos interesses conflitantes e antagônicos - repetimos, todos legítimos prima facie -, a legislação tende a reproduzir este dinamismo social, por meio do estabelecimento de previsões cada vez mais abertas e amplas, deixando ao administrador o dever de, diante do caso concreto, adotar a solução óptima para a tutela dos objetivos públicos previstos no ordenamento.

Com relação ao fundamento político, este se refere à escolha feita pela Administração entre os diversos interesses colidentes em determinado caso. Conforme verificado no capítulo anterior, a multiplicidade de interesses legítimos incidentes sobre determinado caso implica na necessidade de que o agente público analise e pondere qual(is) interesse(s) irá(ão) prevalecer na situação concreta.

Neste sentido, aponta MASSIMO SEVERo GIANNINI ${ }^{305}$ que, ao lado do interesse público primário - considerado como o interesse que a autoridade possui por atribuição tutelar -, há diversos interesses secundários públicos coletivos e privados e que devem ser levados em consideração na decisão a ser tomada. Tais interesses secundários não possuem a mesma função, tendo em vista que alguns possuem a função de atenuar o interesse primário, outros, o reforçam, outros, por sua vez, são tão fortes que bloqueiam a própria realização do interesse primário.

Com efeito, ante a multiplicidade de interesses incidentes no caso, a escolha do(s) interesse(s) prevalecente(s) será o resultado da discricionariedade administrativa,

\footnotetext{
${ }^{303}$ Derecho administrativo, Tomo I, 1947, p. 149. Tradução nossa. No mesmo sentido, cf. JUAN CARLOS CASSAGNE, El principio de legalidad y el control judicial de la dicricionalidad administrativa, 2009, p. 180.

304 CELSO ANTÔNIO BANDEIRA DE MELlo, Legalidade - discricionariedade - seus limites e controle, in Grandes Temas de Direito Administrativo, 2009, p. 59.
}

${ }^{305}$ Diritto amministrativo, vol. II, 1993, p. 48. 
que, nas palavras do professor italiano consiste em uma "ponderação entre comparativa de muitos interesses secundários em relação a um interesse primário"306.

Assim, é possível afirmar que a distinção entre interesse público primário, como sendo o interesse da coletividade a ser tutelado pela Administração, e o interesse público secundário, como representante do interesse do próprio ente administrativo, cunhada por RENATO ALESSI ${ }^{307}$ e recepcionada no direito administrativo brasileiro ${ }^{308}$ merece uma releitura, no sentido de que o interesse público primário é aquele interesse público que decorre do ordenamento jurídico e deve ser perseguido pela Administração na atuação concreta, sendo o interesse público secundário o conjunto de interesses coletivos e privados que devem ser valorados, ponderados e respeitados pela Administração no momento da implementação daquele, servindo, então, como baliza de atuação do Poder Público.

E, em havendo uma pluralidade de interesses públicos, torna-se necessária a coexistência entre eles ${ }^{309}$, sendo a ponderação dos interesses secundário em vista do interesse primário o mecanismo posto à disposição da Administração para tal coexistência, sendo tal ponderação o momento crucial do exercício da discricionariedade administrativa ${ }^{310}$.

Por fim, no que se refere ao fundamento institucional, este decorre da tripartição das funções do Estado, de tal modo que, se a lei previsse todas as situações e modos de atuação da função administrativa, esta se veria tolhida de atuação pela função legislativa, sem que pudesse atuar com um mínimo de liberdade, gerando desequilíbrio entre as funções ${ }^{311}$.

\footnotetext{
${ }^{306}$ Op. cit., p. 49. No original: "ponderazione comparativa di più interessi secondari in ordine ad um interesse primario".

${ }^{307}$ Sistema instituzionale del diritto amministrativo italiano, 1953, p. 151 e segs.

${ }^{308}$ Conferir, entre outros, CElso ANTÔNIO BANDEIRA DE MeLlo, Curso..., cit., p. 65-70

309 FRANCO BASSI, Note sulla discrezionalitá amministrativa, in Sandro Amorosino (coord.) Le Transformazioni del Diritto Amministrativo: Scritti degli allievi per gli ottanta anni di Massimo Severo Giannini, 1995, p. 52.

${ }^{310}$ Massimo SeVERo Giannini, Diritto..., cit., p. 49.

311 Segundo AFONSO RODRIGUES QUEIRÓ, "Logo a partir do momento em que na realidade da vida jurídico-política se procurou instaurar aquilo que o liberalismo jusnaturalista idealizou como sistema de proteção e garantia dos direitos individuais em relação poder executivo (sujeitando êste poder a uma norma eminente, a Lei, e assegurando a observância desta por meio de uma jurisdição, seja ela a dos tribunais ordinários, ou a de tribunais administrativos especiais, ou simultâneamente de uns e outros) - a partir do momento em que na vida jurídica se instauraram o sistema montesquieuano da divisão dos
} 
Na realidade, é ínsita à separação de funções a atribuição de certa margem de liberdade de decisão com relação ao momento e ao conteúdo dos atos a serem expedidos, variando, no entanto, esta atribuição de acordo com o órgão de poder e o momento histórico no qual se insere o plexo de competências que lhe é atribuído que, conforme visto no capítulo I, é variável conforme o tempo.

Assim, se ao legislador é fornecido um espaço de apreciação para a emitir o ato legislativo de acordo com os cânones constitucionais, ao administrador também é necessário que o ordenamento conceda certa margem regulada de atribuição para apreciar qual a melhor forma de agir para a consecução do interesse coletivo daquela atuação específica.

Ainda dentro das noções gerais deste tema, cabe destacar que a discricionariedade está intimamente ligada ao contexto fático do qual decorre o caso concreto, ou seja, é de acordo com os fatos ocorridos que o administrador verificará (i) se a norma de regência lhe confere mais de uma opção de como agir e (ii) se as peculiaridades do caso concreto, analisadas sob os princípios jurídicos administrativos e os postulados da razoabilidade e da proporcionalidade, permitem que haja mais de uma solução juridicamente válida para o caso.

poderes e a idéia rousseauniana da superioridade da lei (da legislação) em relação às outras funções ou poderes estaduais - a partir daí deixou de ser possível reduzir a função executiva a uma atividade puramente mecânica de tradução em ato de imperativos legais, e dêste modo deixou de ser possível submetê-lo a um completo e total contrôle jurisdicional. Daí uma hesitação do órgão ou órgãos jurisdicionais encarregados dêsse controle. Na evolução jurídica da época moderna pode considerar-se capital o momento em que se verificou essa impossibilidade quanto às suas conseqüências na vida jurídica prática e também, e sobretudo, quanto às teoréticas, pois veio oferecer à reflexão dos juristas um torturante problema. Por todo o tempo que o Estado-Polícia regeu na Europa a vida administrativa, o problema não se pôs, e não podia pôr-se: esta não se desenvolvia em obediência aos ditames de uma norma geral e abstrata com eficácia legal, mas sim subordinada à vontade soberana do Príncipe, atuando por meio de ordens e instruções sem eficácia bilateral (Jehring)". (A teoria do 'desvio de poder' em direito administrativo. Revista de Direito Administrativo, ${ }^{\circ}$ 6, p. 49-51).

Nas valiosas palavras de LUIS MANUEL FONSECA PIRES, "a competência discricionária do Poder Público justifica-se pela necessidade de efetivar a identidade do Poder Executivo. Em outros termos, e em companhia de Afonso Rodrigues Queiró, haveria comprometimento do Estado de Direito, na divisão de poderes, se a lei pudesse deixar de ser, como regra, uma norma geral e abstrata para atuar em todo e qualquer caso concreto de execução suas próprias orientações normativas. Em última análise, o Legislativo açambarcaria a competência atribuída ao Executivo que reclama, para assegurar sua existência, de uma parcela de liberdade de atuação". (Controle Judicial..., cit., p. 157). 
Assim, é possível que no texto legal sejam conferidas diversas opções para o administrador agir quando da ocorrência da situação fática ali descrita, mas, diante das peculiaridades do caso concreto e do influxo dos princípios da razoabilidade e da proporcionalidade, somente reste ao administrador uma única solução juridicamente possível.

Tem-se, então, um estreitamento da discricionariedade por tais elementos fáticos e jurídicos. Tal estreitamento decorre do fato de a discricionariedade ser uma competência pública, ligada ao dever de atingimento dos fins públicos preconizados pelo Estado, de tal forma que os poderes colocados ao administrador o são na exata medida da necessidade de atingimento do interesse público. Assim, somente se concebe a escolha de atuação do administrador na exata medida em que esta existir, no caso concreto, como forma de melhor se chegar ao interesse público, o que impede a Administração de escolher, livremente, dentre as diversas atuações legalmente previstas, qual irá realizar, quando a situação fática não permitir tal amplitude de escolha ${ }^{312}$.

\footnotetext{
312 A respeito deste "estreitamento" da discricionariedade administrativa fundamental o quanto exposto por CELSO ANTÔNIO BANDEIRA DE MELlo: "Com efeito, se a lei comporta a possibilidade de soluções diferentes, só pode ser porque pretende que se dê uma certa solução um dado tipo de casos e outra solução para outra espécie de casos, de modo a que sempre seja adotada a decisão pertinente, adequada à fisionomia própria de cada situação, tendo em vista atender a finalidade que inspirou a regra de direito aplicanda. A existência de uma variedade de soluções comportadas em lei outorgadora de discrição evidentemente não significa que esta considere que todas as soluções são igual e indiferentemente adequadas para todos os casos de sua aplicação. Significa, pelo contrário, que a lei considera que algumas delas são adequadas para alguns casos e que outras delas são adequadas para outros casos.

Ora, em sendo verdadeira esta afirmação, em sendo corretas - como certamente o são - as lições de Guido Falzone, segundo quem existe um dever jurídico de boa administração e não apenas um dever moral ou de Ciência da Administração, porque a norma só que a solução excelente, se não for esta a adotada haverá pura e simplesmente violação da norma de Direito, o que enseja correção jurisdicional, dado que terá havido vício de legitimidade. Donde perante eventos desta compostura, em despeito da discrição presumida na regra de direito, se o administrador houver praticado ato discrepante do único cabível, ou se tiver eleito algum seguramente impróprio ante o confronto com a finalidade da norma, o Judiciário deverá prestar a adequada revisão jurisdicional, porquanto, em rigor, a Administração terá desbordado da esfera discricionária, já que esta, no plano das relações jurídicas, só existe perante o caso concreto. Na regra de direito, ela está prevista como uma possibilidade - não como uma certeza. A 'admissão' de discricionariedade no plano da norma é condição necessária, mas não suficiente para que ocorra in concreto. Sua previsão na 'estática' do Direito, não lhe assegura presença na 'dinâmica' do Direito. Pra servirmo-nos de expressões da filosofia aristotélico-tomista: a discricionariedade na regra de direito contém in potencia a discricionariedade in actu, mas nada mais que isto. Logo, não bastará invocar a expressão legal enunciadora de conceito fluido ou que dá liberdade de fazer ou não fazer, o que permite praticar o ato A, B, ou C, para fazer o órgão controlador (interno ou externo) da legitimidade, seja o Judiciário, seja a Administração Pública, tenha que concluir que existe discrição e que, por isso, não pode ser examinado a fundo o ato, sob pena de estar-se entrando no mérito do ato administrativo. É que isto não é 'mérito' do ato administrativo". (Discricionariedade..., cit., p. 36-37).

Também importante a lição de ADILSON ABREU DALLARI:“Está totalmente superado, por ser inteiramente equivocado, o entendimento segundo o qual a discricionariedade que a lei confere ao agente legitima qualquer conduta e, pior que isso, impede o exame pelo Poder Judiciário. Essa questão da discricionariedade precisa ser mais bem explicada, mediante uma comparação entre competência
} 
Vale notar, que o estreitamento da discricionariedade pode chegar ao ponto de eliminá-la, de tal forma que a competência do agente incialmente discricionária acabe por gerar um ato vinculado, ou seja, a despeito de a competência legalmente prevista permitir em tese uma gama de escolhas, pode ser verificado no caso concreto aquilo que se convencionou chamar de discricionariedade zero e conduz à vinculação à uma única solução juridicamente correta ${ }^{313}$.

$\mathrm{Na}$ realidade, a escolha do administrador somente será cabível naquelas situações em que esta se transformar em indiferente jurídico, ou seja, todas as opções, decorrentes do processo de análise do caso concreto e fruto da eliminação daquelas juridicamente impossíveis, são válidas perante o Direito, passando-se à fase de escolha pelo administrador da opção que melhor atenda ao interesse público a ser atingido de acordo com a norma de regência.

E a observação aqui feita não se resume a questões meramente acadêmicas, uma vez que traz consequências para o próprio exercício do controle judicial da Administração. Com efeito, a inexistência de discricionariedade perante um caso concreto implica em vinculação do administrador ao único resultado juridicamente

vinculada e competência discricionária. Quando a lei confere ao agente público competência vinculada, significa que já escolheu previamente qual a única e melhor conduta para a plena satisfação do interesse público. Quando a lei confere ao agente público competência discricionária, isso significa que atribuiu ao agente o dever/poder de escolher a melhor conduta, dentre um universo de condutas possíveis, para a plena satisfação do interesse público. Resulta daí uma enorme diferença entre a competência em tese e o exercício dessa competência diante do caso concreto. Em tese é possível afirmar que a lei estaria validando previamente toda e qualquer das condutas possíveis, mas em concreto, diante do caso concreto, sempre haverá uma só conduta mais adequada à plena satisfação do interesse público. O titular da competência discricionária, diante do caso concreto, não está autorizado a adotar qualquer conduta, mas tem o dever de desvendar e adotar o único comportamento que as circunstâncias indicarem como o mais adequado". (Controle do desvio de poder, Revista Trimestral de Direito Público, n 46, 2004, p. 35). Discordamos, entretanto, de tal autor ao afirmar que o caso somente abrigará uma única solução correta, eis que certamente haverá casos em que duas ou mais soluções serão juridicamente possíveis, autorizando o manejo da competência discricionária.

${ }^{313}$ Tal conceito de discricionalidad cero é bem explorado pela doutrina espanhola e argentina, conforme noticia Agustín GoRdillo (Tratado de derecho administrativo, Tomo 1, 2003, p. X-17). No Brasil, também trabalha com a noção de que a discricionariedade no caso concreto pode levar a uma única solução juridicamente correta o professor CELSO ANTÔNIO BANDEIRA DE MELlO (Legalidade Discricionariedade - Seus limites e controle, in Grandes Temas de Direito Administrativo, 2009, p. 60). 
possível e, portanto, submete o ato expedido ao pleno controle pelo Poder Judiciário ${ }^{314}$, conforme será visto no capítulo III do presente trabalho.

De acordo, então, com o conceito proposto, temos que o chamado mérito do ato administrativo, aqui entendido como o resultado do exercício da competência discricionária $^{315}$, ou seja, aquela disposição do ato administrativo que resulte de uma escolha realizada pelo administrador, somente existirá naquelas hipóteses em que efetivamente o administrador estiver diante de decisões juridicamente válidas (os irrelevantes jurídicos).

Ora, na medida em que o mérito "é o campo de liberdade suposto na lei e que, efetivamente, venha a remanescer no caso concreto, para que o administrador, segundo critérios de conveniência e oportunidade, se decida entre duas ou mais soluções admissíveis perante ele, tendo em vista o exato atendimento da finalidade legal, dada a impossibilidade de ser objetivamente reconhecida qual delas seria a única adequada" ${ }^{316}$, temos que somente nas hipóteses em que efetivamente houver opções válidas é que estaremos diante de um ato emitido na competência discricionária e, portanto, detentor de um mérito administrativo.

Em efetivamente existindo margem para escolha dos critérios de conveniência e oportunidade pelo administrador, inexistirá campo para o controle judicial da escolha administrativa, que resultará no mérito do ato, uma vez que, ao tratar de irrelevantes jurídicos, o ato acabará por exteriorizar apenas a opção que melhor atendeu à finalidade legalmente estabelecida (o interesse público presente no caso), objeto insindicável pelo Judiciário, uma vez que somente ao Poder Público cabe sobre eles decidir ${ }^{317}$.

\footnotetext{
314 Tal pleno controle judicial já levou o Superior Tribunal de Justiça a afirmar a possibilidade de substituição da decisão administrativa pela judicial, nos seguintes termos: "As circunstâncias fáticas podem reduzir a margem de discricionariedade do administrador, ou até eliminá-la, de modo que, quando este age em desconformidade com a finalidade legal, é possível ao Poder Judiciário substituí-lo e tomar a decisão que se ajusta à vontade da lei, sem que isto constitua violação do princípio da separação dos Poderes". (STJ - 2 Turma, REsp 973.686/PR, Rel. Min. Humberto Martins, j. 15.09.2009).

${ }^{315}$ Diogo de FigueIREDO MoreIRA NeTO, Legitimidade..., cit., p. 47.

316 Celso Antônio Bandeira de Mello, Discricionariedade..., cit., p. 38. Na mesma linha, cf. Germana de Oliveira Moraes, Controle jurisdicional..., cit., p. 50.

317 Consoante lição de Germana DE Oliveira MoraEs: "As definições de conveniência e de oportunidade vão, assim, compor substancialmente o mérito do ato administrativo. 'Saber se aquele acto é ou não o meio idôneo para a satisfação do interesse público - escreve Rogério Erhardt Soares, 'se é conveniente ou oportuno, é neste domínio que se afirma o mérito'. Por conveniência do ato, entende-se 'sua adequação ao interesse público especifico que justifica a sua prática ou a necessária harmonia entre
} 


\section{II.D.2 - A Discricionariedade na Atividade Normativa Regulatória}

Colocados os apontamentos acima, cabe a análise de como o instituto da discricionariedade é aplicado na atividade regulatória. A leitura das normas de criação das agências reguladoras pode dar a impressão de que estes entes possuem uma discricionariedade alargada em relação à Administração em geral, tendo em vista a própria estrutura normativa das leis que criam tais entes.

De acordo com Floriano de AzEVEdo MARques Neto ${ }^{318}$, a discricionariedade pode estar prevista nos seguintes elementos da lei: (i) na deslegificação, ou seja, na conferência de margem para que a Administração concretize o comando legal na parte em que o legislador se absteve de fazê-lo; (ii) na utilização de conceitos jurídicos indeterminados; (iii) na prescrição de poderes implícitos, para os quais a lei não traga os meios a serem utilizados pela Administração no atingimento das finalidades legais previstas; e (iv) na conferência explícita de uma margem de escolha para que a Administração escolha pela utilização total ou parcial da sua competência, diante do caso concreto.

E uma leitura das leis que criam as agências reguladoras permite verificar que elas possuem os elementos acima enumerados, de tal forma que tanto transferem para as agências a normatização pormenorizada de dadas matérias, quanto possuem conceitos jurídicos indeterminados em sua estrutura, que serão complementados pelo administrador diante do caso concreto, quanto atribuem uma série de competências às agências para o atingimento das finalidades do setor regulado, sem, contudo, estipular os meios a serem manejados para o atingimento de tais fins, bem como o momento no qual as competências devem ser manejadas.

este interesse e os demais interesses públicos eventualmente afectados pelo ato'. O juízo de oportunidade, por seu turno, consiste na 'ponderação de interesses múltiplos carecidos de acomodação parcial', em vista do fim que se propõe na norma atributiva de discricionariedade. Em síntese, o mérito é o núcleo da discricionariedade e insuscetível de controle jurisdicional, quer à luz de legalidade,que à luz dos princípios de Direito. (...) O terreno do mérito do ato administrativo persiste infenso ao controle jurisdicional, pois reporta-se a regras não positivas de boa administração". (Controle jurisdicional...., cit., p. 51).

${ }^{318}$ Discricionariedade e regulação setorial - o caso do controle dos atos de concentração pelo regulador setorial, in Alexandre Santos de Aragão. O Poder Normativo das Agências Reguladoras, 2a ed., 2011, p. 430 . 
No entanto, a despeito do caráter aparentemente mais aberto da legislação regulatória, as agências reguladoras possuem uma discricionariedade menor do que a de outros entes e órgãos da Administração Pública, o que se verifica por diversas razões.

Em primeiro lugar, pois as finalidades macro da regulação estão previstas no artigo 170 da Constituição Federal, que estipula os fundamentos da ordem econômica e que não podem ser ignorados pelos órgãos reguladores.

Em segundo plano, ainda na matriz constitucional, o artigo 174 impede que o Estado deixe de exercer o seu papel regulador na economia, pois "a criação de uma agência só é justificável se lhe forem atribuídas competências irrenunciáveis de atuar em face do setor regulado, aplicando em concreto as medidas postas à sua disposição com vistas ao cumprimento dos objetivos da regulação setorial" ${ }^{319}$.

Em terceiro lugar, as próprias leis de criação de tais entes determinam quais são as finalidades a serem seguidas em cada setor regulado, o que impede que a regulação setorial seja exercida de acordo com a liberdade dos reguladores, que devem manejar as competências que lhes foram atribuídas com o objetivo de alcançar as finalidades dos setores regulados.

Em quarto lugar, o plexo de interesses envolvidos nos setores regulados e que devem ser levados em consideração, sopesados e equilibrados pela agência ao tomar a decisão normativa implica em importante mecanismo de limitação às escolhas feitas pelo regulador, de tal forma que aquela competência que parece discricionária no texto legal pode ser restringida na ponderação dos interesses no caso concreto.

Em quinto lugar, as características da atividade reguladora do Estado, pautada pela processualidade, participação dos interessados e necessidade de que o ato normativo seja expedido de acordo com os elementos do processo e consoante uma motivação lógica e congruente - o que será visto no próximo item -, impõe uma forte limitação à discricionariedade, uma vez que o ato normativo não poderá contrariar os elementos do processo administrativo ${ }^{320}$.

\footnotetext{
${ }^{319}$ Idem, p. 436.

${ }^{320}$ Floriano DE AZEVEdo MARQues Neto, Op. cit., p. 429.
} 
Em sexto lugar, a constante necessidade que o regular tem de se socorrer de conhecimentos econômicos de outras áreas com a finalidade de editar os atos normativos (tais como economia, contabilidade, engenharia das mais diversas especialidades etc.), ao invés de aumentar o campo de escolhas, acaba, muitas vezes, por reduzi-las ${ }^{321}$.

Assim, todas estas limitações, ao invés de ampliarem a discricionariedade do ente regulador, representam importantes mecanismos de limitação das escolhas administrativas na edição de atos normativos, o que pode implicar, por vezes, na própria ausência de discricionariedade quando da tomada da decisão pelo regulador.

\section{II.E - A Motivação de Acordo com os Elementos do Procedimento}

Outro elemento de fundamental importância na expedição dos atos normativos regulatórios se refere à motivação, que, em nosso sentir, deve sofrer uma nova abordagem no que se refere à atuação das agências reguladoras.

O dever de motivação dos atos administrativos é questão que tem chamado a atenção dos administrativistas há pouco tempo, se comparado com o percurso de duzentos anos de tal ciência. Neste aspecto, apontam ANDRÉ DE LAUBADÈRE, JEAN Claude Venezia e Yves GaUdemeT ${ }^{322}$, que durante muito tempo e de acordo com um tradicional princípio, a Administração não estava obrigada a motivar seus atos, ou seja, a explicitar os motivos de fato e de direito que a levaram a editar determinado ato, sendo que somente em 1979 surgiu na França a lei de 11 de julho, que impôs tal obrigação para diversos atos administrativos, sendo o rol ampliado pela lei de 17 de janeiro de 1986.

No Brasil, tal tendência também foi observada, notadamente durante a segunda metade do século passado, período no qual foram cunhados ensinamentos no sentido da

\footnotetext{
${ }^{321}$ A respeito das questões técnicas como limitadoras da discricionariedade administrativa, cf. MARÇAL JUSTEN FILHO, $O$ direito das agências reguladoras independentes, cit., p. 528 e segs.

${ }^{322}$ Droit administratif, tome I, $13^{\mathrm{a}}$ ed., 1994, p. 635-636. Apontam os autores que, antes de tal período, a motivação era obrigatória somente com relação a alguns atos, seja em virtude de textos legais esparsos, seja em virtude de imposição da jurisprudência.
} 
inexistência de obrigatoriedade da motivação de atos administrativos, salvo quando a lei expressamente os determinar. Assim, por exemplo, THEMÍsTOCLES BRANDÃO CAVAlCANTI asseverou que "A investigação do motivo do ato só se justifica quando assemelhado à legalidade, quando a motivação é explícita e do próprio conteúdo do ato administrativo. Nada pode obrigar a Administração a motivar todos os seus atos, sendo esta apenas condição de alguns atos administrativos" ${ }^{\text {"23 }}$.

Para outros autores, como Hely LOPES MeIRElles, o dever de motivação era maior nos atos tidos como vinculados ou decisórios e dispensável nos atos decorrentes da competência discricionária - tomada pelo autor como poder discricionário. Apontava o autor que "nos atos oriundo do poder discricionário, a justificação será dispensável, bastando apenas evidenciar a competência para o exercício desse poder e a conformação do ato com o interesse público, que é pressuposto de toda atividade administrativa" ${ }^{\circledR 24}$.

Não se nega mais hoje que a motivação é um dos requisitos de validade do ato administrativo de cunho decisório, seja ele expedido no exercício de competência vinculada, seja, principalmente, no de competência discricionária, de tal forma que o vício na motivação implica na ilegalidade do ato administrativo ${ }^{325}$.

Neste passo, o artigo 50 da Lei de Processo Administrativo Federal (Lei $\mathrm{n}^{\circ}$ 9.784/99 $9^{326}$ ) elenca oito hipóteses nas quais a motivação do ato administrativo é obrigatória, sendo que tais incisos contemplam as situações nas quais há efetivamente a tomada de decisões pela autoridade administrativa. Da mesma forma, a Lei de Processo

\footnotetext{
${ }^{323}$ Teoria dos atos administrativos, 1973, p. 76.

${ }^{324}$ Direito administrativo brasileiro, $14^{\mathrm{a}}$ ed., 1989, p. 174.

325 Nesse sentido, cf. MARÇAL Justen Filho, Curso..., cit., p. 442-443 e AleXANDRE SANTOS DE ARAGÃO, Curso de direito administrativo, 2012, p. 153-154. Na linha dos que admitem a motivação como regra geral, o que nos leva a crer que admitem, ainda que implicitamente a possibilidade de ato não motivado, cf. MARIA SYLVIA ZANELlA DI PIETRO, Direito administrativo..., cit., p. 213.

326 “Art. 50. Os atos administrativos deverão ser motivados, com indicação dos fatos e dos fundamentos jurídicos, quando:

I - neguem, limitem ou afetem direitos ou interesses;

II - imponham ou agravem deveres, encargos ou sanções;

III - decidam processos administrativos de concurso ou seleção pública;

IV - dispensem ou declarem a inexigibilidade de processo licitatório;

$\mathrm{V}$ - decidam recursos administrativos;

VI - decorram de reexame de ofício;

VII - deixem de aplicar jurisprudência firmada sobre a questão ou discrepem de pareceres, laudos, propostas e relatórios oficiais;

VIII - importem anulação, revogação, suspensão ou convalidação de ato administrativo".
} 
Administrativo do Estado de São Paulo (Lei Estadual no 10.177/98) impõe o dever de motivação dos atos administrativos, afirmando a invalidade destes nos casos de ausência ou insuficiência de motivação (arts. $4^{\circ}, 8^{\circ}$, incisos IV e VI, e $9^{\circ}$ ).

Em referidas leis houve a expressa previsão não apenas do dever de motivação, mas, mais do que isto, de quais os requisitos que devem ser observados pela autoridade ao editar o ato administrativo, com a finalidade de que a motivação seja considerada válida. Assim, a Lei no 9.784/99 determina que "[A] motivação deve ser explícita, clara e congruente, podendo consistir em declaração de concordância com fundamentos de anteriores pareceres, informações, decisões ou propostas, que, neste caso, serão parte integrante do ato" (art. 50, $\S 1^{\circ}$ ), sendo que a Lei Estadual de São Paulo no 10.177/98 assevera que "[A] motivação indicará as razões que justifiquem a edição do ato, especialmente a regra de competência, os fundamentos de fato e de direito e a finalidade objetivada" (art. $9^{\circ}$, caput).

No entanto, referidas leis não são capazes de determinar, de modo claro e objetivo, o que venha a ser uma motivação válida, ou seja, uma motivação "explícita, clara e congruente" ou mesmo uma motivação que para justificar a edição do ato explicite "a regra de competência, os fundamentos de fato e de direito e a finalidade objetivada" , o que implica na necessidade de investigação de tais critérios para que se possa aferir a validade da motivação do ato administrativo.

Uma primeira nota que deve ser feita é no sentido de que tais critérios de motivação não são novos no direito administrativo brasileiro, tendo em vista que já foram cunhados pela doutrina antes mesmo da edição de tais textos normativos. Com efeito, ANTÔNIO CARlos de ARAÚJo CINTRA, em obra clássica a respeito do tema, já afirmava que a motivação suficiente "deve conter todos os elementos idôneos a justificar a edição do ato administrativo a que se refere, seja no plano da legalidade, seja - tratando-se de ato discricionário - no plano da conveniência e oportunidade" ${ }^{\$ 27}$.

A despeito de reconhecer que os elementos que tornam idônea a motivação variam de caso para caso, o referido autor afirma ser possível definir um esquema

\footnotetext{
${ }^{327}$ Motivo e motivação do ato administrativo, 1979, p. 126-127.
} 
básico pelo qual se possa aferir se a motivação é ou não suficiente ${ }^{328}$. Assim, aponta que a motivação válida deve: (i) indicar as premissas de fato e de direito em que o agente se apoiou para editar o ato administrativo, o que implica na análise das provas em que se baseou o agente e das normas legais aplicadas, sua interpretação e, eventualmente, os motivos de não aplicação de outras normas; (ii) apontar as regras de inferência pelas quais o agente passou das premissas - de fato e de direito - à conclusão, se houver necessidade; (iii) ser precisa em relação ao caso concreto, com a menção às circunstâncias do caso, sem que se possa utilizar de expressões vagas e genéricas e com meras remissões ao "interesse público" ou à "necessidade do serviço"; (iv) ser clara e congruente, com a finalidade de permitir a efetiva comunicação com os destinatários.

Em primoroso trabalho escrito em 1985, portanto antes da Constituição Federal de 1988 e das leis de processo administrativo, CARLOS ARI SundFELD ${ }^{329}$ afirmou categoricamente a necessidade de motivação do ato administrativo como forma de demonstração de sua legalidade e de sua conformidade com o interesse público perseguido pela Administração, sendo inclusive requisito para as prerrogativas da presunção de legitimidade e de executoriedade. De acordo com o autor, a motivação “invocará as normas que autorizam o agir da autoridade, ressalvará, se for o caso, a obediência aos trâmites procedimentais, discriminará os fatos antecedentes e demonstrará sua subsunção à hipótese legal. Além disto, em havendo discricionariedade, seja na escolha ou apreciação dos motivos, seja quanto ao conteúdo, seja quanto à finalidade, justificará suas opções, expondo a causa do ato e demonstrando sua legalidade" ${ }^{, 330}$.

Em outro trabalho específico a respeito do tema da motivação, FLORIVALDO DUTRA DE ARAÚJO ${ }^{331}$ afirma, com farta menção à doutrina estrangeira, que a motivação deve obedecer a quatro requisitos: (i) a congruência, pela qual das premissas invocadas pelo agente (motivos, normas e razões) deve-se extrair a conclusão; (ii) a exatidão, que significa que "as razões de direito devem corresponder aos textos invocados, e que os

\footnotetext{
${ }^{328}$ Op. cit., p. 127-129.

${ }^{329}$ Motivação do ato administrativo como garantia dos administrados, Revista de Direito Público, $\mathrm{n}^{\circ} 75$, jul./set. 1985, p. 118-127.

${ }_{330}$ Op. cit., p. 123-124.

${ }^{331}$ Motivação e controle do ato administrativo, 1992, p. 121-122.
} 
motivos fáticos devem ser verídicos"332; (iii) a suficiência, que implica no dever de a Administração explicitar o percurso lógico e jurídico que a levou a tomar dada decisão expressa no ato administrativo; (iv) a clareza, por meio da qual "o interessado terá o perfeito conhecimento do processo lógico e jurídico que conduziu o agente à decisão" ${ }^{\prime 33}$.

Em segundo lugar, para a correta compreensão do instituto da motivação e dos seus requisitos de validade, devemos compreender a sua finalidade, ou seja, por qual motivo o ordenamento impõe o dever de motivação ao administrador.

A resposta, em nosso sentir, está intimamente ligada ao controle da atuação administrativa, ou seja, é por meio da análise da motivação que se analisará se o ato administrativo foi praticado dentro dos parâmetros e da finalidade legal ou se o agente se valeu da competência outorgada pela lei para praticar ato com desvio de finalidade. Nesta linha, de acordo com MAurice Hauriou, "é nos motivos do ato que o desvio de poder é apreensível." ${ }^{334}$, sendo cabível também o ensinamento de GUIDO ZANOBINI ${ }^{335}$, no sentido de ser característico do desvio de poder a ilogicidade manifesta do ato, que se expressa pela ausência de nexo lógico entre os vários motivos ou entre a motivação e o dispositivo do ato. Ora, sendo a motivação a explicitação dos motivos ${ }^{336}$, há relação umbilical ente a apreciação dos motivos e o controle do ato administrativo.

No mesmo sentido do que aqui defendemos, Michel StassinOPOUlOS ${ }^{337}$ aponta que a motivação é necessária para a atividade de controle da Administração, em virtude do princípio da legalidade e da impossibilidade de controle jurisdicional do mérito do ato administrativo, sendo a motivação, assim, uma forma de comprovar ao juiz que o poder foi exercido dentro dos limites legais, em conformidade com a lei e com os princípios gerais que regem a atividade administrativa. Assim, sem a exigência de

\footnotetext{
${ }^{332}$ Op. cit., p. 121.

${ }^{333}$ Op. cit., p. 122.

${ }^{334}$ Précis de droit administratif et de droit public, $7^{\text {a }}$ ed., 1911, p. 450. No original: "C'est dans les motifs de l'acte que le détournement de pouvoir est saisissable".

${ }^{335}$ Corso di diritto amministrativo, vol. I, 8 a ed., 1958, p. 313.

${ }^{336}$ Motivo e motivação não se confundem, conforme a clássica lição doutrinária, tendo em vista que o motivo "significa as circunstâncias de fato e os elementos de direito que provocam e precedem a edição do ato administrativo", sendo a enunciação destes motivos a motivação. (ODETE MEdAUAR, Direito administrativo moderno, $17^{\mathrm{a}}$ ed., 2013, p. 156).

${ }^{337}$ Traité des actes administratifs, 1973 [reimp. da edição de 1954], p. 198 e 202.
} 
motivação que venha a explicitar a legalidade do ato administrativo, a atuação discricionária da Administração seria incontrolável.

Conforme bem pontua TOMÁS-RAMÓN FERNÁNDEZ ${ }^{338}$, é na motivação da decisão que se começa a diferenciar o discricionário do arbitrário, tendo em vista que a ausência de motivação que sustente a decisão administrativa implica na existência de ato administrativo fundado apenas na vontade do agente, o que é insuficiente no Estado de Direito, no qual não há margem, em regra, para o poder fundado na pessoa do administrador. Ainda na linha do referido professor, valendo-se de duas decisões do Tribunal Supremo Espanhol, exaradas na década de 80 do século passado ${ }^{339}$, a motivação válida deve trazer todas as provas que demonstrem que a decisão possui apoio em realidade fática que valide a legalidade e a oportunidade do agir administrativo, bem como a congruência entre os motivos e finalidades que a justificaram, sem que a Administração possa se valer da mera fórmula da presunção de legitimidade dos atos administrativos, pois a ela recai o dever de motivar sua atuação.

Ora, se o ato administrativo é uma das peças que integra o Estado de Direito e este, por sua vez, é caracterizado pela ideia de controle do poder, resta claro que a exigência de motivação é decorrente da necessidade de controle da Administração, seja na perspectiva do controle interno, seja na do controle externo, o que implica na imperatividade da exigência de motivação do ato administrativo, como decorrência direta do Estado de Direito ${ }^{340}$.

O que resta claro, então, é que a motivação é elemento fundamental do ato administrativo, sendo que a sua ausência ou insuficiência são causas de nulidade do ato administrativo, tendo em vista que a sua ausência ou insuficiência é sinal patente do desvio de finalidade ou abuso de poder ${ }^{341}$.

Tendo em vista, de um lado, as lições doutrinárias e a legislação a respeito da obrigatoriedade da motivação e, de outro, a finalidade dela, parece-nos possível traçar

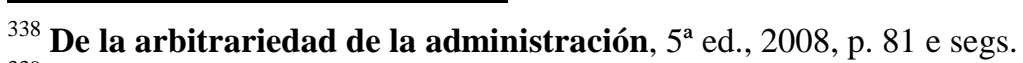

${ }^{339}$ Sentenças de 22.06.1982 e de 15.10.1985.

${ }^{340}$ CARlos ARI SundFEld, Motivação do ato..., cit., p. 120-121.

${ }^{341}$ Nesse sentido, cf. José CRETELla JúNIOR, Anulação do ato administrativo por desvio de poder, 1978, p. 110 e segs.
} 
algumas linhas a respeito da motivação dos atos administrativos no que se refere aos atos normativos regulatórios.

Um primeiro ponto que merece atenção é o fato de que, a despeito de a maioria das leis instituidoras das agências reguladoras no Brasil fazer referência à publicidade dos procedimentos de edição de atos normativos, poucas delas fazem menção ao dever de motivação de tais atos.

Assim, por exemplo, a Lei no 9.478/97 (ANP) possui disposições no sentido de que os atos decisórios da ANP serão submetidos ao princípio da publicidade (art. 17), bem como que "As iniciativas de projetos de lei ou de alteração de normas administrativas que impliquem afetação de direito dos agentes econômicos ou de consumidores e usuários de bens e serviços das indústrias de petróleo, de gás natural ou de biocombustíveis serão precedidas de audiência pública convocada e dirigida pela ANP" (art. 19), sem, contudo, afirmar a necessidade de motivação de tais atos ${ }^{342}$.

Da mesma forma, a Lei $\mathrm{n}^{\circ}$ 10.233/01 (ANTT e ANTAQ), também submete os atos normativos ao princípio da publicidade (art. 66), bem como à necessidade de prévia audiência pública (art. 68, caput), mas não impõe o dever de motivação de tais $\operatorname{atos}^{343}$. No mesmo sentido, a Lei n ${ }^{\circ}$ 9.427/96 (ANEEL) possui disposição no sentido de que "O processo decisório que implicar afetação de direitos dos agentes econômicos do setor elétrico ou dos consumidores, mediante iniciativa de projeto de lei ou, quando possível, por via administrativa, será precedido de audiência pública convocada pela ANEEL" (art. $\left.4^{\circ}, \S 3^{\circ}\right)$, sem, contudo, impor o dever de motivação aos atos normativos expedidos.

\footnotetext{
${ }^{342}$ O regimento interno da ANP, aprovado pela Portaria no 69/2011, também não dispõe a respeito da motivação dos atos normativos, sendo que o artigo 56, ao tratar das audiências públicas apenas determina: "Art. 56. As iniciativas de projetos de lei ou de alteração de normas administrativas que impliquem afetação de direitos dos agentes econômicos ou de consumidores e usuários de bens e serviços da indústria do petróleo serão precedidas de consulta e audiência pública, convocadas pela Diretoria Colegiada da ANP e dirigidas pelos titulares das unidades da estrutura organizacional respectiva ou por servidores por eles indicados.

Parágrafo único. Os objetivos básicos das consultas e audiências públicas são:

I - identificar e debater os aspectos relevantes da matéria em discussão;

II - recolher subsídios, informações e dados para a decisão ou o encaminhamento final do assunto;

III - propiciar aos agentes econômicos, usuários e consumidores, a possibilidade de oferecerem comentários e sugestões sobre a matéria em discussão; IV - dar publicidade e transparência às ações da ANP”.

343 O Regimento Interno da ANTT também nada dispõe a respeito da motivação dos atos normativos, conforme se verifica do artigo 108 da Resolução no 3.000/09.
} 
Diversamente das leis acima mencionadas, a Lei $n^{\circ}$ 9.472/97 (ANATEL) trouxe expressamente o dever de motivação nos artigos $40^{344}$ e $42^{345}$, o que implica em importante avanço legislativo.

Diante destas disposições legais, pode surgir o seguinte questionamento: não tendo ocorrido a estipulação do dever de motivação nas leis criadoras da ANTAQ, ANTT, ANEEL e ANP (tomadas aqui apenas exemplificativamente), estariam os atos normativos por elas expedidos eximidos do dever de motivação? Somente os atos normativos da ANATEL são de motivação obrigatória?

A resposta, em nossa concepção é negativa às das perguntas, tendo em vista que entendemos que todos os atos normativos devem ser devidamente motivados, o que decorre de três fatores.

Em primeiro plano, da natureza de atos administrativos que estes possuem, o que, por si só, é fundamento suficiente para obrigar a agência a fundamentar o seus atos, sendo certo que não faria qualquer sentido submeter os atos administrativos de efeitos individuais ao dever de motivação e excluir de tal obrigação os atos normativos ${ }^{346}$.

Em segundo lugar, as leis que instituem tais autarquias são dotadas de dispositivos que conferem finalidades sem, contudo, estipular os meios de alcançá-las, o que implica na atribuição de competências discricionárias que, por isto mesmo, devem ser objeto de fundamentação detida, para que se evite que tais competências se transformem em arbítrio.

Em terceiro lugar, a intensa conflituosidade dos interesses que permeiam a atividade regulatória implica na necessidade de que a Administração justifique as razões de agir de uma forma ou de outra, com a análise dos argumentos aduzidos pelos interessados, com a finalidade de legitimar a decisão tomada, conferindo transparência à

\footnotetext{
344 “Art. 40. Os atos da Agência deverão ser sempre acompanhados da exposição formal dos motivos que os justifiquem".

345 "Art. 42. As minutas de atos normativos serão submetidas à consulta pública, formalizada por publicação no Diário Oficial da União, devendo as críticas e sugestões merecer exame e permanecer à disposição do público na Biblioteca" (g.n.).

${ }^{346}$ CARlos ARI SundFeld e JACINTHO ARRUda CÂMARA, O dever de motivação na edição de atos normativos pela Administração Pública, Revista de Direito Administrativo e Constitucional, $\mathrm{n}^{\circ}$ 45, jul./set. 2011, versão eletrônica.
} 
atividade regulatória. A este respeito, importantes os ensinamentos de GIANDOMENICO MAJONE:

\begin{abstract}
"O meio mais simples e básico de melhorar a transparência e a responsabilização das agências é exigir que os reguladores fundamentem suas decisões. Isto porque a exigência de tal fundamentação ativa um número de outros mecanismos para controlar o critério regulador, tais como o exame judicial, a participação e a deliberação públicas, o exame pelos pares, a análise de políticas para justificar prioridades regulatórias, e assim por diante" ${ }^{, 347}$.
\end{abstract}

Também importante o quanto afirmado por JULIA BLACK, ao asseverar que a procedimentalização "coloca o ônus no emissor, que deve apresentar razões que o outro possa entender. Requer, ainda, que o receptor reconheça o emissor, e o direito de ambos de ser parte da deliberação, bem como de suas visões serem levadas a sério (tendo em mente, é claro, que cada um será tanto emissor quanto receptor)" ${ }^{3_{3}}$.

Ainda no que se refere ao dever de motivar, inquestionável no âmbito da edição de atos normativos regulatórios, outro problema que se coloca diz respeito a como realizar a motivação legítima, de tal modo que não se questiona mais se, mas sim como motivar.

Neste sentido, de acordo com o quanto visto até o presente momento do trabalho, parece-nos ser possível traçar algumas diretrizes de como deve ser devidamente motivado um ato normativo regulatório, com a finalidade de legitimar a expedição de normas pelas agências reguladoras.

Em primeiro lugar, a agência reguladora deverá analisar todas as manifestações ofertadas pelos interessados, com a exposição motivada a respeito da opção $\operatorname{adotada}^{349}$, tendo em vista que de nada adiantaria estabelecer-se um procedimento amplo e com a participação de diversos interessados, se a agência viesse posteriormente a selecionar as manifestações sobre as quais irá tecer comentários.

\footnotetext{
${ }^{347}$ Do estado positivo..., cit., p. 77.

348 Procedimentalizando a regulação: parte II, in Paulo Todescan Lessa Mattos (org.), Regulação Econômica...cit., p. 171.

${ }^{349}$ MARÇAL JuSTEN FILHO, O direito das agências reguladoras independentes, cit., p. 568.
} 
Assim, entendemos ser necessário que a agência analise cada uma das contribuições ofertadas pelos interessados e as acolha ou rejeite motivadamente na decisão, sem que o requisito da motivação seja satisfeito pela manifestação apenas a respeito dos elementos e argumentos acolhidos pela agência.

Em segundo lugar, a motivação deve ser exercida em um sentido forte, na linha do quanto propugnado por CARLOS ARI SUNDFELD e JACINTHO ARRUDA CÂMARA, de tal forma que:

\begin{abstract}
"[A] ideia aqui lançada busca sustentar a existência de um dever de motivar as decisões de caráter regulamentar num sentido forte. Não basta arrolar artigos e incisos de lei ou constitucionais. A Administração, ao motivar, deve explicar e expor os motivos que a levaram a decidir daquele modo e não de outro. Deve apontar os estudos de natureza técnica, econômica, científica que tenham servido de base para aquela regulamentação"350.
\end{abstract}

Assim, a motivação deve abranger detidamente todos os aspectos técnicos, jurídicos e fáticos que foram levantados no procedimento administrativo, com a finalidade de que se possa compreender o que foi decidido ${ }^{351}$, as razões para tanto e, mais do que isto, o porque de não se admitir outra decisão para a normatização em apreço. Não vale, portanto, para o âmbito da regulação - e mesmo para os atos administrativos em geral - a jurisprudência dos tribunais brasileiros, relativa às decisões judiciais, no sentido de que "se os fundamentos adotados bastam para justificar o concluído na decisão, o julgador não está obrigado a rebater, um a um, os argumentos utilizados pela parte" ${ }^{352}$.

Em terceiro plano, a motivação deve ser certa e determinada para o caso concreto, sem que se possa valer de conceitos amplos e vagos, tais como "interesse público", "saúde pública" etc. como única ou uma das principais razões de decidir. É dizer: por mais que as agências tenham sido instituídas para a tutela de determinados objetivos de interesse público, exercendo a regulação sobre atividades de interesse coletivo, isto não significa que as decisões normativas por elas tomadas devam ser feitas com base no argumento do "interesse público".

\footnotetext{
${ }^{350} \mathrm{O}$ dever de motivação...cit.

351 É o quanto de depreende da própria Lei de Processo Administrativo Federal, cujo artigo 38, $\$ 1^{\circ}$, determina que "Os elementos probatórios deverão ser considerados na motivação do relatório e da decisão".

${ }^{352}$ STJ - $3^{\text {a }}$ Turma, AgRg no Ag 1.140.328/RJ, Rel. Min. Sidnei Beneti, j. 18/08/2009.
} 
Por mais que a decisão que atenda ao interesse público seja aquela que deverá prevalecer no caso concreto, o procedimento de justificação para se chegar a ela deve ser técnico-racional, ou seja, derivar racionalmente dos elementos técnicos, jurídicos e fáticos do procedimento regulatório, sem que se possa lançar mão única e principalmente de argumentos calcados em princípios gerais que quase nada dizem a respeito das soluções de casos concretos ${ }^{353}$.

Em quarto lugar, a motivação do ato normativo regulatório deve trazer em si uma visão prospectiva, ou seja, deve demonstrar que a solução adotada pela Administração não apenas é a melhor no momento presente, como também se mostra a mais acertada de acordo com os efeitos futuros da decisão sobre o sistema regulado e os demais sistemas com ele relacionados, o que demanda a explicitação de como o regulador enxerga os impactos futuros do ato administrativo, inclusive sob os aspectos de razoabilidade e proporcionalidade ${ }^{354}$.

Assim, é necessário que o agente regulador demonstre na decisão como se operará o impacto do ato regulatório no setor regulado e nos demais setores com ele conexos no momento presente, além de uma ponderação ex ante e de forma prospectiva a respeito dos impactos da decisão no futuro, no que se refere à razoabilidade e proporcionalidade da medida, bem como dos efeitos econômicos projetados.

Em quinto lugar, como regra, a motivação deve ser contemporânea ou pretérita à edição do ato, "a fim de assegurar sua legitimidade e impedir que a Administração pretenda inovar na motivação de seus atos ao sabor de eventual impugnação do

\footnotetext{
${ }^{353}$ Para uma acertada e bem humorada crítica do argumento com base em princípios gerais no direito administrativo, cf. CARLOS ARI SUNDFELD, Crítica à doutrina dos princípios do direito administrativo, in , Direito Administrativo para Céticos, $2^{\mathrm{a}}$ ed., p. 179-203.

$\overline{354}$ De acordo com SÉRGIO GUERRA: "A regulação exercida pelas Agências Reguladoras deve ser implementada por meio de uma interpretação prospectiva, para o futuro. Esse aspecto, que sempre deve estar presente na orientação do agente regulador, poderá custos, benefícios e impactos da ação regulatória no subsistema a ele afeto. Nesse contexto, pode-se avaliar que para a validade dos atos regulatórios emanados das Agências Reguladoras impõe-se que os mesmos sejam devidamente motivados, com a perfeita identificação da fundamentação técnica e a razoabilidade e proporcionalidade justificadora da decisão que atingirá todo um subsistema (motivação do ato regulatório)". (Introdução ao direito das agências reguladoras, 2004, p. 51-52).
} 
particular afetado" ${ }^{355}$. Excluem-se deste dever os atos normativos que não possuam confronto com a esfera de direitos dos administrados diretamente, tais como os atos de organização interna da agência, os que aprovam as regras de licitação, bem como aqueles atos normativos de setores regulados nos quais ainda não haja interessados, como ocorre com a regulação original de um novo serviço público ${ }^{356}$.

\section{II.F - Conclusões Parciais}

Do quanto demonstrado no presente capítulo, é possível concluir, em primeiro lugar, que a natureza jurídica da competência normativa das agências reguladoras é a de delegação legislativa, instituto expressamente autorizado pela Constituição atual e que sempre foi utilizado no direito brasileiro, mesmo no período da Carta de 1946, que expressamente o vedava, ante o fenômeno da mutação constitucional.

Em segundo lugar, é possível concluir que as agências reguladoras, a despeito de serem compostas por membros não eleitos que gozam de mandatos estáveis, possuem sua legitimidade democrática nos procedimentos administrativos prévios à edição dos atos normativos, o que nos remete ao conceito de democracia procedimental.

De acordo com tal tipo de democracia, a legitimidade do agir estatal está não apenas no voto recebido pelos eleitores, mas também na procedimentalização da atuação administrativa, com a finalidade de permitir a todos os interessados a oportunidade de oferecer argumentos que venham a influir na tomada da decisão pela Administração.

Nesse passo, as agências reguladoras devem realizar procedimentos administrativos prévios à edição de atos normativos regulatórios, com a finalidade de permitir que todos os agentes do setor possam influir na tomada de decisão que venha a

\footnotetext{
355 EgOn Bockmann Moreira, Processo administrativo..., cit., p. 374. Não negamos a doutrina que defende a possibilidade de motivação posterior dos atos administrativos vinculados - também conhecida como motivação aliunde -, hipóteses nas quais bastaria a comprovação da ocorrência do fato descrito na norma para gerar a motivação (cf. neste sentido: EGON BOCKMANN MOREIRA, Processo administrativo..., cit., p. 374 e CElso ANTÔNIO BANDEIRA DE MEllo, Curso..., cit., p. 115-116). No entanto, ao falarmos de atos normativos regulatórios, tais hipóteses são praticamente inexistentes, de modo que entendemos não ser cabível maior delonga com relação a tais situações de motivação posterior.

${ }^{356}$ CARlos ARI SUNDFEld e JACINTHO ARRUdA CÂMARA, O dever..., cit.
} 
se refletir na expedição do ato normativo regulatório, o que implica em importante requisito procedimental a ser analisado.

No que se refere aos requisitos materiais para a expedição dos atos normativos, as agências devem obediência aos princípios da subsidiariedade, eficiência, razoabilidade e proporcionalidade, que norteiam toda a atividade regulatória, devendo ser analisados de acordo com as finalidades legalmente estabelecidas para o setor regulado.

Também ganha relevo a necessidade de uma motivação para a expedição do ato regulatório que seja totalmente condizente com o processo administrativo, ou seja, que traduza os elementos do processo, com os argumentos levados pelas partes devidamente respondidos, bem como que seja racional, o que a constitui em importante elementos para a diferenciação entre a decisão legítima e a arbitrária.

Ainda no que se refere aos requisitos materiais, foi demonstrado que a discricionariedade dos entes reguladores é menor do que a dos demais entes da Administração, uma vez que os aspectos procedimentais, materiais, as finalidades do setor regulado e a tecnicidade das decisões acabam por impor uma série de limitações à escolha concreta do regulador no momento de editar o ato normativo. 


\section{CAPÍTULO III - O CONTROLE JUDICIAL DOS ATOS NORMATIVOS DAS AGÊNCIAS REGULADORAS NO BRASIL}

“[L]a qualité d'une décision est appréciée en function des principles qu'elle met en ouvre, mais aussi des consequences qu'elle entraîne".

(Julie Allard e Antoine Garapon) ${ }^{357}$

Nos capítulos anteriores tratamos, de um lado, de contextualizar o debate travado no presente trabalho e, de outro, de demonstrar como se opera a atividade normativa das agências reguladoras no Brasil, com a verificação dos pressupostos processuais e materiais que devem ser observados e obedecidos por tais autarquias para a validade de seus atos normativos.

No presente capítulo, pretendemos analisar a questão do controle judicial da atividade normativa das agências reguladoras, notadamente no que se refere aos limites institucionais impostos ao Judiciário e à luz do consequencialismo jurídico.

\section{III.A - Colocação do Problema: O Judiciário Brasileiro e o Controle da} Administração Pública entre a Bipolaridade e a Explosão da Conflituosidade

Conforme verificado no capítulo I, o direito administrativo somente começa a ser delineado como objeto autônomo de estudo a partir do momento em que há a concentração do poder nas mãos do soberano e ocorre a delimitação de tal poder, com a estipulação de regras a serem seguidas na atuação administrativa (princípio da legalidade).

Assim, a essência do direito administrativo de matriz europeia-continental foi cunhada com base em um caráter bipolar ${ }^{358}$ da relação entre Estado e cidadãos: a autoridade versus a liberdade. Neste passo, ao mesmo tempo em que eram atribuídas à Administração Pública diversas prerrogativas de atuação, tais como a

\footnotetext{
${ }^{357}$ Les juges dans la mondialisation. La nouvelle revolution de droit, 2005, p. 67

358 A respeito da bipolaridade na construção do direito administrativo, cf. FLORIANO DE AZEVEDO MARQues Neto, A concessão..., cit., p. 489 e segs.
} 
autoexecutoriedade dos atos administrativos, as cláusulas exorbitantes nos contratos administrativos, discricionariedade insindicável pelo Judiciário etc. (vertente da autoridade), estipulavam-se formas de controle para conter o poder e garantir os direitos dos cidadãos (vertente da liberdade).

Diante desta relação de bipolaridade, surgiu a necessidade da criação de órgãos de controle externo da Administração, com a finalidade de verificar se a atuação administrativa efetivamente atendeu aos parâmetros legalmente estabelecidos. Dentre os órgãos incumbidos do controle do aparato administrativo, os países ocidentais tiveram a preocupação de submeter a Administração ao controle jurisdicional ${ }^{359}$, o que implicou no surgimento, em suma ${ }^{360}$, de dois tipos de jurisdições de controle.

No direito administrativo europeu continental, o sistema que mais ganhou força foi o da dualidade de jurisdição, originado na França pós-revolucionária e que se espalhou pelos demais países do continente. Tal sistema implica na existência de dois órgãos independentes responsáveis pela aplicação do direito, por exarar a juris dictio, de modo que contra as decisões por eles tomadas em última instância não há a possibilidade de interposição de qualquer medida a outro órgão estatal para a desconstituição do quanto decidido. Assim, um órgão jurisdicional fica responsável pelo julgamento de questões afetas à Administração Pública (o Conselho de Estado) e outro, pela resolução dos casos que envolvam a aplicação do direito comum (o Poder Judiciário).

Tal sistema é magistralmente esclarecido nas palavras de ODETE MEDAUAR:

"O sistema de jurisdição dupla, de dualidade de jurisdição ou dualista caracteriza-se pela existência paralela de duas ordens de jurisdição: a jurisdição ordinária ou comum e a jurisdição administrativa, esta destinada a julgar litígios

\footnotetext{
359 Controle jurisdicional entendido como aquele realizado por algum órgão estatal que possua a competência para decidir algum conflito jurídico de forma definitiva, ou seja, no caso do direito administrativo, para revisar a atuação do administrador - do ponto de vista jurídico -, de modo definitivo, sem que contra as decisões de última instância de tal órgão caiba qualquer medida para outro órgão visando a desconstituição da decisão. Assim, jurisdicional não se confunde obrigatoriamente com judicial, do que é exemplo o sistema de jurisdição dupla, que possui a jurisdição administrativa e a jurisdição judicial.

${ }^{360}$ Aponta ODETE MedauAR a existência de três tipos de sistemas: o da dualidade de jurisdição, o da unidade de jurisdição e o misto. (Controle da Administração Pública, $2^{a}$ ed., 2012, p. 191). No entanto, para a finalidade do presente trabalho, interessam-nos apenas os sistemas de unidade e dualidade de jurisdição.
} 
que envolvam a Administração Pública. A jurisdição administrativa ou contencioso administrativo forma um conjunto hierárquico de juízes e/ou tribunais administrativos, encabeçados por um órgão supremo próprio, de regra denominado Conselho de Estado ou Corte Suprema Administrativa, independente do tribunal supremo da jurisdição ordinária, e cujas decisões representam a última instância"361.

Tal jurisdição dupla se originou na França em virtude de uma interpretação um tanto extremada do princípio da separação das funções estatais (executiva, legislativa e judiciária), impulsionada pela desconfiança que os revolucionários franceses tinham com relação à magistratura.

Nesse passo, apontam André de LAubadère, JeAn-Claude Venezia e YveS GAUDEMENT $^{362}$ que, em primeiro plano, havia a impressão de que a submissão dos atos administrativos ao Poder Judiciário implicaria em afronta ao princípio da separação dos poderes, tendo em vista que este poderia causar empecilhos às operações dos corpos administrativos. Tal concepção vigente à época possuía uma preocupação histórica concreta, advinda da forma de atuação do Parlamento (que abrigava o corpo de magistrados, que após a Revolução seria alocado nos tribunais judiciários), seja no Antigo Regime, quando obstruiu as tentativas de reformas pretendidas pelo Rei, seja no próprio período revolucionário, quando o Parlamento se mostrou hostil à Revolução empreendida, de modo que a burguesia que ascendia ao poder possuía concretos receios de que as novas concepções que passariam a vigorar fossem obstadas pelo Poder Judiciário, entendido, então, como "rival do poder administrativo".

Em virtude de tal construção teórica, surgiu, ainda em 1789, o decreto de 22 de dezembro, que determinava: “As administrações de departamentos e distritos não poderão ser perturbadas no exercício de suas funções administrativas por nenhum ato do poder judiciário". Posteriormente, foi editada a lei 16-24 de agosto de 1790, cujo artigo 13 dispunha: "As funções jurisdicionais são distintas e permanecerão sempre separadas das funções administrativas; os juízes não poderão, sob pena de prevaricação, perturbar, por qualquer forma, as operações dos corpos administrativos, nem citar perante si os administradores em razão de suas funções" ${ }^{363}$.

\footnotetext{
${ }^{361}$ Controle..., cit., p. 193.

${ }^{362}$ Droit administratif..., cit., p. 280. Para uma leitura feita pelos ingleses a respeito da dualidade de jurisdição francesa, cf. ALBERT VENN DICEY, Introduction..., cit., p. 337 e segs.

363 Apud Odete Medauar, Controle..., cit., p. 194.
} 
Tal sistema de dualidade de jurisdição amplamente aceito e utilizado na Europa continental também chegou a vigorar parcialmente no Brasil na época do Império, com a criação em 1824 do Conselho de Estado, órgão que, num primeiro momento, teve funções unicamente consultivas, mas que, ao longo do século XIX, foi tendo a si incorporadas funções jurisdicionais, ainda que $\operatorname{limitadas}^{364}$. No entanto, sem ter efetivamente exercido a função de controlar os atos administrativos do Imperador, o Conselho de Estado foi considerado como um colaborador do Império e instituição típica da Monarquia, o que levou à sua extinção quando da proclamação da República, em 1889.

O outro sistema de controle jurisdicional da Administração é o de unidade de jurisdição, pelo qual há apenas um órgão estatal encarregado de decidir os conflitos a respeito da aplicação do direito em caráter definitivo, esteja o Estado envolvido ou não em ditos conflitos. Assim, é da jurisdição comum a competência para o julgamento dos litígios em geral, inclusive aqueles que envolverem a Administração Pública.

Tal sistema possui sua origem nos países da Common Law (principalmente Inglaterra e Estados Unidos ${ }^{365}$ ), que possuem como base do direito administrativo, ao contrário do que se dá nos países de matriz continental, a inexistência de qualquer privilégio ou prerrogativa para a Administração Pública nas suas relações com os particulares, o que inclui a submissão de todos ao mesmo órgão jurisdicional ${ }^{366}$, excluída, portanto, a criação de uma jurisdição especial para a solução dos litígios do Poder Público.

\footnotetext{
${ }^{364}$ A respeito da evolução da competência do Conselho de Estado no Brasil, cf. JULIANA BONACORSI DE PALMA, Atividade normativa..., cit., p. 110-111, e JOSÉ REINALDO DE LIMA LOPES, O oráculo de Delfos: o Conselho de Estado no Brasil-Império, 2010, p. 91 e segs.

${ }^{365}$ Para um aprofundamento histórico a respeito das causas do surgimento de unidade de jurisdição em tais países, cf. EDUARDO LOBO BOTELHO GUALAZZI, Justiça administrativa, 1986, p. 115-120.

${ }^{366}$ Segundo AlbERT VENN DiCEY, "Droit administratif, in short, rests upon ideas absolutely foreign to English law: the one, as I have already explained, is that the relation of individuals to the State is governed by principles essentially different from those rules of private law which govern the rights of private persons towards their neighbours; the other is that questions as to the application of these principles do not lie within the jurisdiction of the ordinary courts. This essential difference renders the identification of droit administratif with any branch of English law an impossibility". (Introduction..., cit., p. 388).
} 
A unidade de jurisdição foi adotada no Brasil desde a Constituição de $1891^{367}$, sendo repetida em todas as constituições posteriores, variando apenas a expressa menção, ou não, aos limites do controle judicial. Assim, a Constituição de 1934, no artigo 68, afirmava ser "vedado ao Poder Judiciário conhecer de questões exclusivamente políticas". A Constituição de 1937, em um cenário de maior restrição às liberdades, trouxe igualmente a vedação ao controle judicial de atos exclusivamente políticos (art. 94), além de vedar a apreciação judicial dos atos praticados em estado de guerra ou de emergência (art. 170). As Constituições de 1946, 1967 e 1969 estipularam que "A lei não poderá excluir da apreciação do Poder Judiciário qualquer lesão de direito individual" (arts. $141, \S 4^{\circ} ; 150, \S 4^{\circ}$; e $153, \S 4^{\circ}$ ), cláusula que evoluiu para o atual art. 5', XXXV, da atual Constituição, no sentido de que "a lei não excluirá da apreciação do Poder Judiciário lesão ou ameaça a direito".

No entanto, tal adoção do modelo de unidade de jurisdição trouxe uma grave contradição para o direito administrativo brasileiro, com importantes consequências para o controle da Administração.

Com efeito, ao mesmo tempo em que as Constituições estabeleciam o sistema de unidade jurisdicional - baseado, então, no sistema da Common Law, que não prevê qualquer tipo de privilégio ao Estado no trato com o cidadão -, o direito administrativo brasileiro buscava suas fontes doutrinárias na matriz francesa, concedendo prerrogativas de atuação da Administração Pública, sem, no entanto, importar da França o modelo de dualidade jurisdicional que formou - e ainda forma - os contornos do direito administrativo de tal país.

Na realidade, a jurisprudência do contencioso administrativo é instrumento de constante evolução da ação administrativa, pois, como bem aponta MARIA PAULA DALLARI BUCCI, a jurisdição administrativa francesa possui duas funções: controlar o exercício do poder e organizar a ação da Administração Pública, o que é feito por meio de sua jurisprudência, que "é quem sedimenta a experiência administrativa. As decisões

\footnotetext{
367 “Art 60 - Compete aos Juízes ou Tribunais Federais, processar e julgar:

(...)

b) todas as causas propostas contra o Governo da União ou Fazenda Nacional, fundadas em disposições da Constituição, leis e regulamentos do Poder Executivo, ou em contratos celebrados com o mesmo Governo".
} 
do contencioso administrativo vão fixando os padrões de conduta aceitos para a Administração. A evolução desses padrões tem como marco os arestos da jurisprudência administrativa" ${ }^{368}$.

Neste sentido, CHARLES EISENMANN ${ }^{369}$ afirma que as grandes questões jurídicas que envolvem a Administração não são regradas pelo legislador, pois tais questões são resolvidas com base em princípios gerais que regem o Estado, que raramente estão previstas em leis e textos regulamentares, havendo matérias em que inexiste qualquer texto de legislativo, decorrendo da aplicação de máximas pelo juiz administrativo ${ }^{370}$.

E os exemplos da construção de temas fundamentais para o direito administrativo pelo Conselho de Estado e pelo Tribunal de Conflitos ${ }^{371}$ são colhidos aos montes. Assim, o critério de ato administrativo - como veículo exarado no exercício de prerrogativas públicas - para a finalidade de fixar a competência do Conselho de Estado foi firmado quando do julgamento do Arrêt Canal de Gignac (1899); a exigência de que os contratos administrativos tenham cláusulas exorbitantes do direito comum, para que possam ser caracterizados como tais, foi instituídos no Arrêt Société des Granits porphyroïdes des Voges (1912); a preservação do equilíbrio econômico-financeiro do contrato administrativo, seja pela mutabilidade imposta pela Administração (Arrêt Compagnie Générale Française de Tramwais, 1910), seja pela aplicação da teoria da imprevisão (Arrêt Compagnie Générale d'Éclairage de Bordeaux, 1916), também decorreram de construção jurisprudencial; a responsabilidade civil da Administração também decorre de uma construção jurisprudencial da jurisdição administrativa, conforme se verifica dos Arrêts Blanco (1873), Pelletier (1873), Cames (1895), Anguet (1911) etc etr $^{372}$

\footnotetext{
${ }^{368}$ Direito administrativo e políticas públicas, $1^{\text {a }}$ ed., $2^{\text {a }}$ tir., 2006, p. 225.

${ }^{369}$ Cours..., cit., p. 310-311.

$370 \mathrm{O}$ que leva, por outro lado, à uma certa instabilidade dos regramentos impostos à Administração Pública, pois estes podem ser alterados de acordo com a conviç̧ão dos magistrados em outro período. A respeito dos efeitos da instabilidade jurisprudencial no direito administrativo francês - tema que obviamente não será tratado aqui - cf. HUGUES LE BERRE, Les revirements de jurisprudence en droit administratif de l'an VIII à 1998 (Conseil d'État et Tribunal de Conflits), Paris: LGDJ, 1999.

371 Órgão responsável por solucionar os conflitos de competência entre a jurisdição administrativa e a jurisdição ordinária.

${ }^{372}$ Para um aprofundamento a respeito de tais julgamentos, cf. M. LONG et alli, Les grands arrêts de la jurisprudence administratif, $18^{\mathrm{a}}$ ed., Paris: Dalloz, 2011; e JEAN-FranÇOIS LANCHAUME et alli, Droit administratif: les grandes décisions de la jurisprudence, Paris: PUF, 2010.
} 
O que tal análise demonstra é que, para o direito administrativo francês, a jurisdição administrativa possui importante função na formação e consolidação dos institutos a serem aplicados pelos administradores, sendo, portanto, o órgão de controle, dotado de características não apenas de reprimenda do agir administrativos, mas também de construção da dogmática de tal ramo jurídico ${ }^{373}$.

No Brasil, no entanto, o sincretismo dogmático (unidade de jurisdição somado direito administrativo de matriz francesa) formou um modelo "lacunoso quanto à organização e ainda falho quanto ao controle" ${ }^{374}$, sem que houvesse qualquer instituição capaz de estabelecer parâmetros mínimos de atuação aplicáveis a toda a Administração Pública, de tal modo que "as tentativas de erigir um sistema administrativo brasileiro, sempre a partir de algum modelo mal copiado ou mal adaptado do exterior são em parte responsáveis pela irracionalidade administrativa que perdura ainda hoje" ${ }^{\text {375 }}$.

O fato é que a forma de controle pela via da unidade de jurisdição implica na possibilidade de submissão de todas as questões jurídicas à apreciação judicial, o que, dentro da perspectiva bipolar do direito administrativo (autoridade $\mathrm{x}$ liberdade) representava basicamente a anulação da atuação administrativa pela ilegalidade praticada, consoante a lição de MigUEL SEABRA FAGUNDES:

"O controle jurisdicional se torna oportuno quando os efeitos do ato administrativo incidem sobre o administrado (excepcionalmente, quando esteja na iminência de incidir) e tem como resultado obstá-los, uma vez reconhecida a ilegalidade.

O Poder Judiciário, chamado a atuar no processo de realização do direito, para remover normalidade nele surgida, circunscreve o âmbito da sua atuação ao caso sobre o qual tenha sido provocado. Extinguindo-se a situação anormal com o seu pronunciamento, cessa, por isso mesmo, a razão de ser da sua interferência" ${ }^{376}$.

O Judiciário, assim, foi alçado ao ponto máximo do controle da Administração do ponto de vista jurídico, com atuação adstrita ao binômio legalidade/ilegalidade ${ }^{377}$ da

\footnotetext{
${ }^{373}$ Nesse passo, importante verificar que Albert Venn Dicey, ao observar e comparar os sistemas do Common Law e do droit administratif francês, afirmou que ambos se assemelham por serem decorrentes da construção pretoriana, sendo direitos construídos pelo case-law ou judge-made law (Introduction..., cit., p,. 373-375).

${ }^{374}$ MARIA PAUla DALlari BuCCI, Direito administrativo..., cit., p. 226.

375 Idem, p. 231.

${ }^{376}$ O controle..., cit., p. 193-194.

${ }^{377}$ Binômio que pode ser entendido como juridicidade/antijuridicidade, tendo em vista que o direito não é apenas a lei e que o jurídico e o legal não se confundem. Manteremos, no entanto, a menção a legalidade/ilegalidade, por ser o que mais aparece na literatura a respeito da matéria.
} 
atuação administrativa, sem que tal intervenção tenha a intenção de construir uma dogmática ou uma forma de agir a ser seguida pela Administração Pública. O controle judicial, quando da existência de ilegalidade administrativa, tem, por consequência, anular os atos inválidos.

Neste quadrante de bipolaridade, a função atribuída ao Poder Judiciário é a de resguardar a legalidade, com a finalidade de evitar o abuso de poder, não a de efetivar as finalidades legais, o que implica no exercício de um controle com baixa ou nenhuma preocupação com os efeitos de tal anulação. Ao juiz, em tal panorama simplório da relação Estado (autoridade) versus cidadão (liberdade), basta a aferição da legalidade/ilegalidade da atuação administrativa para, caso seja ilegal, estar autorizado pelo ordenamento a anular o ato praticado à margem das normas.

É dentro deste quadrante que vislumbramos os principais debates a respeito do controle judicial da Administração Pública, ou seja, os principais autores a respeito do tema possuem como pressuposto de análise o caráter bipolar do direito administrativo, bem como a análise judicial pautada única e exclusivamente pelo binômio legalidade/ilegalidade. Assim, os grandes debates a respeito do tema se centram na maior ou menor possibilidade de o Judiciário anular os atos administrativos, o que nos remete aos temas do controle do mérito do ato administrativo, que será abordado adiante.

No entanto, ao que nos parece, as alterações sociais das últimas décadas impõem a necessidade de uma nova luz sobre o tema, notadamente ante os conflitos sociais cada vez mais comuns e que passaram a desembocar no Judiciário, forçando-o a se manifestar sobre questões coletivas, de índole eminentemente distributiva, em substituição às questões de índole retributiva que são a marca dos conflitos intersubjetivos.

$\mathrm{Na}$ realidade, diante de uma legislação cada vez mais abrangente e que contempla direitos para grupos antagônicos - a começar pela Constituição Federal -, que passam a pressionar o Estado no atendimento de seus interesses, a judicialização ${ }^{378}$ de

\footnotetext{
378 “Judicialização significa que questões relevantes do ponto de vista político, social ou moral estão
} sendo decididas, em caráter final, pelo Poder Judiciário. Trata-se, como intuitivo, de uma transferência de 
questões distributivas passa a ser até mesmo intuitiva, eis que "constitucionalizar é, em última análise, retirar um tema do debate político e trazê-lo para o universo das pretensões judicializáveis" ${ }^{379}$.

Afinal, se as relações sociais estão regradas pelo direito e este deve ser interpretado em última instância pelo Poder Judiciário, especialmente naqueles países que abraçam a inafastabilidade do controle judicial, a hipertrofia da lei implicará na judicialização de todas as relações sociais. Nesse sentido, lembra-nos Luís ROBERTO BARROSO $^{380}$, que praticamente todas as questões relevantes do ponto de vista social, moral ou político acabaram sendo objeto de julgamento pelo Supremo Tribunal Federal em recente período, como as questões de células-tronco embrionárias (ADI 3.510-DF), demarcação da reserva indígena Raposa Serra do Sol (Pet. 3.388-RR), interrupção da gestação de fetos anencefálicos (ADPF-54), ações afirmativas e quotas sociais e raciais (ADI 3.330) etc.

Assim, contra todas as manifestações dos demais Poderes do Estado, que se dão por meio da linguagem jurídica, será, ao menos em tese, cabível o controle judicial, com a finalidade de analisar se a interpretação do direito pelo agente público foi feita corretamente ou não, bem como se houve violação ou ameaça a direito.

Some-se a esta hipertrofia legislativa, duas características do Poder Judiciário no Brasil, que em muito contribuem para a judicialização: (i) de um lado, a vedação ao non liquet ${ }^{381}$, que impede que o juiz deixe de julgar sob o argumento de inexistência de norma legal que se aplique ao caso. Assim, ao contrário do Legislativo e do Executivo que podem não decidir determinadas demandas sociais ou postergar a decisão, com a finalidade de não arcar com o preço político de suas ações, o Judiciário é obrigado a decidir as questões que lhe são submetidas ${ }^{382}$; (ii) de outro lado, a formação do

poder para as instituições judiciais, em detrimento das instâncias políticas tradicionais, que são o Legislativo e o Executivo". (Luís ROBERTO BARROSO, Constituição, democracia e supremacia judicial: direito e política no Brasil contemporâneo, Revista Trimestral de Direito Público, no 55, jul. 2011, p. 39-76, acesso à versão digital).

${ }^{379}$ LUÍs ROBERTO BARROSO, Constituição.., cit.

380 Idem, ibidem.

${ }^{381}$ Adotada expressamente no Brasil pelo art. 126 do Código de Processo Civil: "O juiz não se exime de sentenciar ou despachar alegando lacuna ou obscuridade da lei. No julgamento da lide caber-lhe-á aplicar as normas legais; não as havendo, recorrerá à analogia, aos costumes e aos princípios gerais de direito".

${ }^{382}$ Celso Fernandes Campilongo, Política..., cit., p. 41. 
Judiciário por membros vitalícios e não eleitos implica na existência de um Poder, ao menos em tese, não suscetível a pressões políticas, com decisões tomadas em caráter técnico-jurídico e não guiadas em sua maior parte por critérios subjetivos e personalíssimos, como ocorre com a política. Logo, aqueles grupos que se sentem desprezados pelas decisões políticas acabam por recorrer ao Judiciário com a esperança de que seus interesses sejam atendidos pela via judicial, já que não obtiveram êxito na arena política propriamente dita.

Tal conjugação de fatores faz com que a judicialização se constitua em "um fato inelutável, uma circunstância decorrente do desenho institucional vigente, e não uma opção política do Judiciário. Juízes e tribunais, uma vez provocados pela via processual adequada, não têm a alternativa de se pronunciarem ou não sobre a questão" ${ }^{383}$. Diante disso, parece-nos que a judicialização da política é fenômeno que não pode ser negado, sendo decorrente da própria invasão do direito em todos os campos sociais, políticos e econômicos, sem que se possa lutar contra tal tendência.

No âmbito das atividades regulatórias, esta questão se coloca mais latente. Com efeito, os atos normativos das agências reguladoras serão expedidos por meio de atos jurídicos, que trazem em si elementos técnicos, econômicos e políticos (de política regulatória), de tal forma que, sob a roupagem jurídica, há outros tantos elementos não jurídicos que integram tal ato.

Assim, a despeito de possuírem a forma jurídica, tais atos guardam em si elementos distintos do sistema jurídico, de modo que o controle sobre eles, por mais que à primeira vista possa parecer eminentemente jurídico - pois, afinal, ao menos do ponto de vista do rótulo externo é um ato administrativo normativo - é, na realidade, multifacetado, abrangendo diversas outras considerações de ordem política, econômica e técnica.

Logo, da mesma forma que se dá com a judicialização em geral (das relações políticas, sociais e econômicas), parece-nos que controle judicial dos atos normativos das agências reguladoras deve seguir duas linhas de questionamentos.

\footnotetext{
${ }^{383}$ Luís RoBerto BARRoso, Constituição.., cit.
} 
Em primeiro lugar, devemos questionar qual a profundidade que o controle judicial deve ter sobre tais atos, ou seja, qual o limite à revisibilidade judicial dos atos que expressam uma política regulatória. Aqui, entra em cena a questão dos obstáculos institucionais a que a judicialização da política venha a se tornar em ativismo judicial, conceitos que para nós não se confundem, tendo em vista que a judicialização é a atribuição de competência judicial para dirimir conflitos que tradicionalmente eram resolvidos pela política, ao passo que o ativismo judicial é a forma de exercício de tal competência ${ }^{384}$.

Em segundo plano, devemos perguntar se a forma tradicional de controle dos atos administrativos, calcada na relação bilateral do direito administrativo (liberdade versus autoridade) e cujo foco principal é a nulidade dos atos tidos como ilegais, numa relação binária ilegalidade $=$ nulidade, é suficiente ou não para o resguardo tanto dos direitos fundamentais, quanto das finalidades legais tuteladas pela lei que embasou o ato administrativo sub judice.

O presente capítulo possui a pretensão de responder a estas duas perguntas.

\section{III.B - A Legitimidade do Judiciário para o Controle de Atos Normativos Regulatórios}

O primeiro ponto a ser analisado se refere à legitimidade do Poder Judiciário para analisar os atos normativos das agências reguladoras, questão que se coloca ante os aspectos políticos, econômicos, técnicos e jurídicos que são subjacentes a tais atos, expedidos sob a roupagem de normas jurídicas. Ou seja, ante este aspecto complexo dos atos normativos regulatórios, haveria a possibilidade de o Judiciário - que, ao menos em tese, somente analisa questões jurídicas - ser provocado a aferir a validade de tais atos administrativos normativos?

\footnotetext{
${ }^{384}$ Nesse sentido, cf. LUís RoBERTO BARROSO, Constituição..., cit. Em sentido contrário, considerando judicialização da política e ativismo judicial como faces da mesma moeda, cf. José RODRIGO RODRIGUEZ e MARCOS NoBRE, Judicialização da política? Sobre a naturalização da separação de poderes (I), in José Rodrigo Rodriguez, Como decidem as cortes? Para uma crítica do direito (brasileiro), p. 177-199.
} 
A resposta a tal questão implica na análise do significado da garantia prevista no artigo $5^{\circ}$, inciso XXXV, da Constituição Federal, que determina: "a lei não excluirá da apreciação do Poder Judiciário lesão ou ameaça a direito". Tal disposição alberga aquilo que se considera como a consagração da tutela judicial efetiva, tendo em vista que garante a tutela tanto com relação à lesão quanto à ameaça a direitos ${ }^{385}$. Assim, a tutela judicial pode ser buscada pelos interessados nos casos em que houver direitos ofendidos ou ao menos ameaçados.

No entanto, isto não significa que a tutela judicial efetiva implique na possibilidade de que qualquer tipo de conflito social possa ser levado à apreciação judicial, nem que tal garantia impossibilite a estipulação de regras procedimentais a serem observadas pelos cidadãos no acesso à tutela judicial. Tem-se, então, que os próprios sistemas constitucional e processual podem estabelecer limitadores legítimos ao acesso à jurisdição.

Assim, do ponto de vista do sistema constitucional, especificamente no que se se refere à separação de funções estatais, o Judiciário não pode se imiscuir em funções que devem ser desempenhadas por outros órgãos de poder, tais como o planejamento e a execução de políticas públicas, os atos eminentemente políticos ou mesmo o exercício do ato de legislar. Assim, o que deve ficar registrado é que "a garantia constitucional da ação não significa, certamente, uma garantia ilimitada de acesso do Poder Judiciário a todas as questões da vida nacional, nem mesmo uma garantia ilimitada de acesso de todo e qualquer tipo de conflito ao Poder Judiciário" ${ }^{386}$.

Nesta toada, por exemplo, o Supremo Tribunal Federal possui forte jurisprudência no sentido de que a anistia é ato político, calcado em juízos de conveniência e oportunidade insindicáveis pelo Poder Judiciário, salvo nos casos de abuso do poder de legislar e de afronta ao devido processo legal ${ }^{387}$. No entanto, em havendo lesão a direitos, ainda que oriunda de atos políticos, mostra-se legítima a intervenção judicial, conforme se verifica de precedente que afirma: "Controle judicial

\footnotetext{
${ }^{385}$ GILMAR FERREIRA MENDES et alli, Curso...cit., p. 480.

${ }^{386}$ Marcos Paulo Veríssimo, Aproximação sistemática..., cit., p. 34.

387 ADIn 1.231/DF, Rel. Min. Carlos Velloso e ADIn 2.036, Rel. Min. Ellen Gracie, apud GILMAR FERREIRA MENDES et alli, Curso...cit., p. 491.
} 
do impeachment: Possibilidade, desde que se alegue lesão ou ameaça a direito" ${ }^{388}$. Assim, ainda que o ato questionado em juízo possua uma índole política, se ele lesar ou ameaçar direitos, é possível que haja a intervenção judicial com a finalidade de tutelas os direitos assegurados pelo ordenamento jurídico.

De outro lado, no que se refere aos limites procedimentais, a cláusula da inafastabilidade de jurisdição implica na existência de um direito de ação em sentido amplo, ou seja, um direito a que o Judiciário analise a pretensão deduzida pela parte, ainda que para afirmar que ela não atende às formalidades procedimentais.

Com efeito, o amplo acesso à jurisdição não significa que este deva se dar por qualquer meio, mas sim, por outro lado, que sejam estabelecidas regras procedimentais voltadas à própria preservação da garantia de acesso à justiça, de tal forma que "As garantias constitucionais do direito de petição e da inafastabilidade da apreciação do Poder Judiciário, quando se trata de lesão ou ameaça a direito, reclamam, para o seu exercício, a observância do que preceitua o direito processual (art. $5^{\circ}, \mathrm{XXXIV}, a, \mathrm{e}$ XXXV, da CF/1988)" ${ }^{389}$.

Assim, o próprio sistema jurídico estipula uma série de limitações e condicionantes ao acesso à jurisdição, com a finalidade de se auto proteger e evitar a autofagia, o que se daria se as demandas judiciais pudessem ser propostas de qualquer maneira, sem a existência de requisitos procedimentais e de legitimidade que regrassem a forma de acesso ao Judiciário ${ }^{390}$.

\footnotetext{
${ }^{388}$ MS 21.689, Rel. Min. Carlos Velloso, julgamento em 16-12-1993.

${ }^{389}$ STF - Pleno, Pet 4.556-AgR, Rel. Min. Eros Grau, j. 25.06.2009. Em outra oportunidade, asseverou a o STF que "Os princípios constitucionais que garantem o livre acesso ao Poder Judiciário, o contraditório e a ampla defesa, não são absolutos e hão de ser exercidos, pelos jurisdicionados, por meio das normas processuais que regem a matéria, não se constituindo negativa de prestação jurisdicional e cerceamento de defesa a inadmissão de recursos quando não observados os procedimentos estatuídos nas normas instrumentais." (1 $1^{a}$ Turma, AI 152.676-AgR, Rel. Min. Maurício Corrêa, j. 15.09.1995). Na mesma linha, mais recentemente, restou consignado que "A CR estabeleceu que o acesso à justiça e o direito de petição são direitos fundamentais (art. $5^{\circ}, \mathrm{XXXIV}, a$, e XXXV), porém estes não garantem a quem não tenha capacidade postulatória litigar em juízo, ou seja, é vedado o exercício do direito de ação sem a presença de um advogado, considerado 'indispensável à administração da justiça' (art. $133 \mathrm{da} \mathrm{CF}$ e art. $1^{\circ}$ da Lei 8.906/1994), com as ressalvas legais. (...) Incluem-se, ainda, no rol das exceções, as ações protocoladas nos juizados especiais cíveis, nas causas de valor até vinte salários mínimos (art. $9^{\circ}$ da Lei 9.099/1995) e as ações trabalhistas (art. 791 da CLT), não fazendo parte dessa situação privilegiada a ação popular." (STF - Pleno, AO 1.531-AgR, voto da Rel. Min. Cármen Lúcia, j. 03.06.2009).

${ }^{390} \mathrm{Com}$ efeito, em atenção à própria necessidade de se estabelecerem tais limites, o Supremo Tribunal Federal tem considerado lícitas, por exemplo, a fixação de prazo decadencial para a impetração de mandado de segurança (Súmula $n^{\circ} 632$ - "É constitucional lei que fixa prazo de decadência para
} 


\section{III.C - Os Problemas Institucionais do Controle Judicial dos Atos Normativos das}

\section{Agências Reguladoras}

No entanto, a existência da jurisdição una no Brasil não impede que o controle judicial gere problemas dogmáticos, notadamente no que se refere ao controle dos atos normativos das agências reguladoras, que expressam medidas de política regulatória, aqui entendida como a escolha "do ente incumbido da atividade regulatória acerca dos instrumentos de regulação à seu dispor com vistas à consecução das pautas de políticas públicas estabelecidas para o setor regulado"391.

Com efeito, se a própria noção de controle judicial da Administração Pública sempre gerou polêmicas a respeito da extensão e dos limites impostos a tal atividade, ainda quando o objeto sobre o qual recaía o controle era um ato praticado num contexto intersubjetivo entre o Estado e o cidadão, parece-nos claro que o controle sobre atos normativos dos entes de regulação tende a trazer maiores problemas institucionais para a atividade de controle.

Ao falarmos de problemas institucionais fazemos referência à questão da separação de funções e da atribuição aos diversos entes e órgãos estatais de competências diversas para o exercício das finalidades públicas atribuídas ao Estado, de tal forma que o nosso ponto de análise se restringe a verificar como um desses órgãos, o Poder Judiciário, deve se portar na análise e controle dos atos emitidos pelas agências reguladoras, institucionalmente competentes para o regramento e fiscalização de atividades econômicas. Assim, não analisaremos questões como (i) lentidão do Poder Judiciário para solucionar as demandas que envolvem as agências reguladoras, (ii) a insegurança jurídica pelo Judiciário com a concessão e cassação de liminares de acordo com a instância (primeira, segunda ou superior) que analisa o feito; (iii) a falta de conhecimento dos membros do Judiciários e de seus auxiliares a respeito de matérias

impetração de mandado de segurança") e a estipulação de taxa judiciária ${ }^{390}$, sendo certo que, com relação à esta última, o seu cálculo sem limites sobre o valor da ação, implica em afronta à garantia do acesso à jurisdição (Súmula no 667 - "Viola a garantia constitucional de acesso à jurisdição a taxa judiciária calculada sem limite sobre o valor da causa.").

${ }^{391}$ Floriano DE AZEVEDO MARQUES NETO, Agências reguladoras..., cit., p. 87-88. 
atinentes à regulação econômica; (iv) os efeitos de tais questões sobre os agentes regulados e os entes reguladores etc ${ }^{392}$.

Ademais, ao falarmos de problemas institucionais, não estamos nos referindo propriamente aos limites do controle judicial, mas apenas apontando eventuais problemas que poderão ocorrer em virtude do exercício de tal controle sobre o sistema regulado.

De outro lado, o presente tópico não se constitui em qualquer crítica ao Judiciário ou menosprezo de nossa parte a respeito dos direitos sociais, que possuem a finalidade de efetivar a isonomia material entre os cidadãos. Estamos plenamente cientes de que a maioria das demandas que aportam ao Judiciário para discutir questões que envolvam saúde, educação, moradia etc. são fruto da falta de planejamento administrativo para a consecução de finalidades constitucionalmente asseguradas aos cidadãos e não cumpridas pelo Estado, também, em virtude da corrupção e do aparelhamento partidário da máquina administrativa. Nossa preocupação com este tópico é apenas a de apontar problemas que surgem quando da politização dos tribunais.

A análise será feita tendo em vista as divergências entre as características das funções judiciais e de estruturação e implementação de políticas regulatórias, que, em nosso sentir, equipara-se à formulação de políticas públicas - no entanto com um objeto mais restrito e menos macro, pois centrada no setor regulado -, de tal modo que a doutrina mencionada a seguir, a despeito de fazer referência às políticas públicas, parece-nos pertinente para discutir a judicialização da política regulatória.

\section{III.C.1 - Os Problemas Ligados às Diferenciações entre Administração e Judiciário}

Um primeiro problema que surge na análise do controle judicial da atividade regulatória diz respeito às formas de diferente de agir das agências reguladoras e do Judiciário, sem que façamos com isto referência às funções primordiais diferentes que

\footnotetext{
392 Para uma aprofundada análise teórica e empírica de tais questões, cf. JULIANO SOUZA DE Albuquerque Maranhão, Paulo Furquim de AZEVEdo e Tercio SAmPaio Ferraz Júnior (coords.) Direito regulatório e concorrencial no Poder Judiciário, São Paulo: Editora Singular, 2014.
} 
exercem. Referimo-nos às diferentes formas pelas quais decidem as questões que lhes são atribuídas institucionalmente.

Conforme passaremos a demonstrar, a despeito de tanto as agências, quanto o Judiciário possuírem procedimentos decisórios a respeito das matérias que lhes são submetidas para análise, há notáveis diferenças entre as formas pelas quais eles atuam, o que implica em importantes consequências para o controle judicial da regulação.

\section{III.C.1.1 - Imutabilidade da Coisa Julgada e Mutabilidade Técnico-Econômica das Relações do Mercado}

O primeiro problema que vislumbramos no controle judicial dos atos normativos das agências reguladoras se refere a um conflito entre a imutabilidade da coisa julgada e a mutabilidade a que estão sujeitos todos os agentes de determinado mercado regulado.

Com efeito, o ordenamento jurídico brasileiro consagra a imutabilidade das sentenças de mérito não mais sujeitas a recurso, com a finalidade de evitar que a mesma questão venha a ser novamente suscitada perante o Judiciário, mesmo após a emissão de decisão que analise o mérito da causa, o que implicaria na ausência de segurança e estabilidade das relações jurídicas.

À esta qualidade de imutabilidade da sentença, que projeta os seus efeitos para além do processo no qual foi proferida, denomina-se coisa julgada material, cujo resguardo pelo ordenamento jurídico é perceptível tanto em nível constitucional, com a previsão no artigo $5^{\circ}$, inciso XXXVI, da Constituição Federal, de que "a lei não prejudicará o direito adquirido, o ato jurídico perfeito e a coisa julgada", quanto infraconstitucional, com a estipulação pelo artigo 467 do Código de Processo Civil, no sentido de que "Denomina-se coisa julgada material a eficácia, que torna imutável e indiscutível a sentença, não mais sujeita a recurso ordinário ou extraordinário”.

Assim, o que se percebe é que, no Brasil, a decisão judicial que enfrenta o mérito de uma causa está sujeita ao efeito da imutabilidade, qualidade esta que não está presente nas políticas regulatórias, sempre sujeitas às alterações impostas pelas 
condições técnicas e econômicas que afetam o setor regulado e à interação entre os próprios agentes de tal setor (prestadores, reguladores e usuários de diversas categorias).

Do ponto de vista técnico-econômico, os serviços regulados, sejam eles enquadrados na categoria de serviços públicos ou não, são serviços que estão constantemente sujeitos à mutabilidade, ante a descoberta de novas tecnologias, de novas formas de aperfeiçoamento e da pressão dos próprios usuários. Assim, os setores regulados estão mais afetos à noção de rebus sic stantibus, do que à de imutabilidade da coisa julgada.

Logo, a imutabilidade da coisa julgada pode ser prejudicial para o futuro do setor regulado, uma vez que podem ocorrer situações (p.ex. fixação de tarifas, modos de prestação do serviço etc.) nas quais tal qualidade da sentença proferida possa prejudicar a evolução tecnológica do setor regulado. À constante revisão das questões políticas, fixadas com base em "testes" realizados pelos agentes administrativos, contrapõe-se a imutabilidade da coisa julgada.

Um exemplo, em tanto hipotético, pode ajudar a visualizar a questão. Em algumas ações judiciais, tem sido questionada a forma pela qual a ANATEL realiza a divisão territorial das regiões atendidas pelo serviço de telefonia, para fins de definição da "área local" e, consequentemente, de cobrança da discagem direta a distância (DDD). As ações judiciais costumam questionar a ausência de identidade entre a divisão promovida pela ANATEL e a divisão político-geográfica, o que levaria à ausência de isonomia entre os consumidores, tendo em vista que alguns que fazem ligações para localidades mais próximas acabariam por pagar tarifas mais altas dos que alguns que fazem ligações para localidades mais distantes.

O Superior Tribunal de Justiça possui o entendimento no sentido de que "os critérios adotados pela ANATEL para delimitação da chamada "área local" para efeito de cobrança de tarifa de telefonia fixa local ou interurbana, observam dados técnicos, não necessariamente vinculados à divisão político-geográfica dos Municípios. Desse 
modo, o Poder Judiciário somente atuará com legitimidade quando e se a Agência Reguladora extrapolar os limites de sua atividade legal" ${ }^{393}$.

Assim, o posicionamento do Judiciário é no sentido de que preservar a competência da ANATEL para a fixação da "área local", com a finalidade de definir as tarifas a serem cobradas para as ligações.

No entanto, suponhamos que o Judiciário, ao invés de tomar tal atitude, resolvesse efetivamente se imiscuir no mérito do ato normativo com a finalidade de definir o que deve ser considerado como "área local" para os fins da ação proposta, ou seja, para a localidade abrangida pelo ato normativo questionado. Nesta hipótese, mesmo que o Judiciário tomasse a decisão baseado em pareceres técnicos, econômicos, que o processo participasse com ampla participação dos interessados, para a política regulatória setorial, a decisão não seria das melhores, ante a impossibilidade de alteração futura.

Com efeito, a partir do momento em que transitasse em julgado a decisão determinando o que seria a "área local” para a localidade abrangida pela ação, tal critério não poderia mais ser alterado ao longo do tempo, ainda que fosse necessário para manter o equilíbrio do sistema regulado, o que colocaria obstáculo para o bom desenvolvimento do setor.

Vale notar que a observação aqui feita não se liga a qualquer análise qualitativa da decisão judicial, ou seja, se ela seria ou não melhor que a decisão da ANATEL no momento do controle. A análise que fazemos se refere ao problema que a imutabilidade da coisa julgada traz ao controle da política regulatória, no que se refere à impossibilidade de mudança posterior do quanto decidido na decisão judicial.

No que toca à interação entre os agentes regulados, é ínsita à regulação estatal a busca por um equilíbrio sistêmico, que venha ser exercida por meio da interlocução entre os agentes do sistema regulado e o ente regulador, sendo esta interação, inclusive,

${ }^{393}$ STJ - $1^{\text {a }}$ Turma, AgRg no REsp 1.171.443/RS, Rel. Min. Napoleão Nunes Maia Filho, j. 06.02.2014. No mesmo sentido: REsp. 1.164.700/PR, Rel. Min. Humberto Martins, DJe 17.05.2010; REsp. 1.009.902/SC, Rel. Min. Herman Benjamin, DJe 11.09.2009 e REsp. 757.971/RS, Rel. Min. Luiz Fux, DJe 19.12.2008. 
o principal motivo pelo qual surgiram as agências reguladoras no Brasil. Consoante Floriano DE Azevedo MARques Neto, “A emergência de entes reguladores autônomos corresponde indubitavelmente à necessidade do poder público de constituir espaços em que sejam possíveis a articulação e a mediação de interesses, em que seja viável a interlocução com os diversos pólos de poder político existentes na Sociedade contemporânea" ${ }^{394}$.

Diante desta realidade, o equilíbrio entre os agentes tende a ser alterada ao longo do tempo, em virtude dos próprios jogos econômicos e das mudanças tecnológicas a que tais setores regulados são submetidos, o que tende a intensificar o efeito rebus sic stantibus sobre eles.

Ora, para setores nos quais a estabilidade é substituída pela instabilidade decorrente do jogo técnico-econômico, bem como da interação constante entre os agentes regulados, parece-nos que a imutabilidade da coisa julgada pode representar obstáculo ao bom desenvolvimento de tais sistemas.

\section{III.C.1.2 - Restrição da Visão Judicial aos Elementos do Caso e Visão Macro da Administração a Respeito do Sistema Regulado}

Em segundo lugar, o Judiciário somente pode se manifestar nos estritos termos das postulações postas pelas partes, o que decorre, de um lado, da inércia da jurisdição (art. $2^{\text {o }}$ do Código de Processo Civil ${ }^{395}$ ) e, de outro, do princípio do dispositivo, que impede o juiz de conhecer de fatos e de pedidos além dos feitos pelas partes na ação, conforme se verifica do artigo 460 do diploma processual civil: "É defeso ao juiz proferir sentença, a favor do autor, de natureza diversa da pedida, bem como condenar o réu em quantidade superior ou em objeto diverso do que lhe foi demandado".

E tais limitações de ordem processual fazem com que o Judiciário possua apenas uma visão pontual do problema da política pública ou política regulatória em análise. É dizer: ao invés de possuir uma visão macro do problema e das soluções que

\footnotetext{
${ }^{394}$ A nova regulação..., cit., p. 81.

395 "Nenhum juiz prestará a tutela jurisdicional senão quando a parte ou o interessado a requerer, nos casos e forma legais".
} 
podem ser adotadas ou das correções necessárias, o Judiciário possui apenas a visão daquele problema específico em jogo na ação proposta.

Assim, por exemplo, no caso da política pública de saúde, o magistrado não possui a visão global da política instituída pelo governo, seus beneficiários, suas fontes de custeio etc., mas apenas a visão do problema daquele cidadão que buscou junto à Administração determinado tratamento de saúde e não foi atendido.

De outro lado, a Administração Pública possui uma visão bem mais ampla do objeto sobre o qual expedirá a política pública ou regulatória, uma vez que possui informações a respeito das fontes de receitas, qual o público que necessita de tal política (beneficiários), qual o objeto que será entregue, qual o melhor meio para o atingimento da finalidade etc., informações estas de que não dispõe o Judiciário no julgamento da ação que verse a respeito da política pública ou regulatória.

\section{Conforme Celso Fernandes CAMPILONGO:}

“o Judiciário tem uma visão necessariamente casuística, descontínua e fragmentária, própria de quem examina o problema nos limites da lide proposta pelas partes (comutativamente) e não com referência à totalidade de relações circulares entre o público, o político e o administrativo (distributivamente). O sistema político trata das decisões globais e o sistema jurídico trata de decisões isoladas. Dada a complexidade e interdependência dos diversos programas de ação governamental, é natural que o sistema político desenvolva uma revisão e correção dos efeitos de suas iniciativas. O sistema jurídico, se bem que possa estar orientado para as consequências da decisão, não vê nem controla o impacto de suas medidas. O juiz trabalha quase que exclusivamente com as referências de sua formação generalista. Nas questões mais específicas, quando muito, pode valer-se de peritos capazes de produzir ou complementar peças probatórias. (...) Em suma, o sistema jurídico trabalha com informações e ferramentas menos imponentes e menos numerosas, se não absolutamente inadequadas, para iniciar, corrigir ou interromper políticas públicas" ${ }^{, 396}$.

E tais visões diversas do magistrado e do agente público implicam em consequências relevantes para a problematização do controle das políticas públicas ou regulatórias, tendo em vista (i) que o exercício da função judicial para além de determinados limites implicará na fixação da política pelo magistrado, por exemplo, como ocorre com diversas ações civis públicas nas quais o Ministério Público pretende impor a política pública a ser estabelecida; e (ii) mesmo em casos de conflitos

\footnotetext{
${ }^{396}$ Política..., cit., p. 105-106.
} 
individuais contra o Estado, a concessão de liminares possui o condão de desestabilizar a política setorial planejada.

Assim, por mais que do ponto de vista subjetivo, do cidadão que ingressa com a ação judicial, possa ser vantajosa a concessão de medida para que a Administração lhe forneça determinada prestação ${ }^{397}$, ante a satisfação de suas necessidades, do ponto de vista institucional, a longo prazo, a medida costuma se mostrar problemática, ante as deficiências que ela cria na questão do planejamento de tais atividades estatais, que devem ser revistas no curso da implementação, para atendimento às decisões judiciais.

No que se refere à política regulatória, o Judiciário, ao realizar o seu controle, acaba por não considerar os aspectos técnicos e finalísticos do setor regulado, observando apenas as consequências da decisão para o direito subjetivo em jogo, sem possuir uma análise macro do sistema regulado e para os demais agentes do setor, o que pode prejudicar o planejamento da política regulatória ${ }^{398}$. Assim, no ímpeto de tutelar direitos tidos como excluídos pela agência reguladora, o Judiciário acaba por interferir na política regulatória, o que pode implicar em consequências drásticas para todo o setor regulado.

\section{III.C.1.3 - Vedação Judicial ao non liquet e Possibilidade de Postergação da Decisão pela Agência Reguladora}

Outro problema que se coloca no controle judicial dos atos normativos das agências reguladoras se refere à impossibilidade de o Judiciário se recusar a decidir determinada matéria ou posterga-la em demasia, o que é permitido às autoridades administrativas.

Conforme já mencionado no presente texto, vigora no Brasil a vedação ao non liquet $^{399}$, que impede que o juiz deixe de sentenciar ou despachar, sob o argumento de inexistência de norma aplicável. Diante disto, para toda ação ajuizada deve haver a

\footnotetext{
397 Fernando dias Menezes de Almeida e Mariana Augusta dos Santos Zago, Controle de políticas públicas pelo Poder Judiciário: breves ideias a partir do modo de estruturação da jurisdição, in Carlos Ari Sundfeld e André Rosilho (coord.), Direito da Regulação e Políticas Públicas, 2014, p. 103.

398 Juliano Souza de AlbuQuerque Maranhão, PAulo Furquim de AZEVEdo e Tercio SamPaio FERRAZ JÚNIOR (coords.) Direito regulatório..., cit., p. 242.

${ }^{399}$ Prevista no art. 126 do Código de Processo Civil, já mencionado anteriormente.
} 
prolação de sentença que a extinga, seja para analisar o mérito da causa, seja para extingui-la por questões processuais.

E mais, não só deve haver uma decisão final no processo, como o Judiciário não possui a opção temporal de quando analisar determinado processo, uma vez que o andamento processual é feito quase que automaticamente, seguindo-se cada uma das fases processuais não de acordo com a vontade do juiz e dos servidores, mas sim de acordo com as regras processuais e procedimentais estipuladas nas leis e normas internas dos Tribunais. Em suma, não apenas o juiz é obrigado a julgar, como não possui condições de escolher quando julgar, para mitigar os efeitos sociais de suas decisões.

Em sentido oposto, o Executivo e o Legislativo possuem maior margem de escolha do momento de agir para a implementação e execução de uma política pública ou regulatória, de tal modo que possuem margem de apreciação do momento de agir e da melhor forma de fazê-lo, o que permite calcular os efeitos sociais, políticos e econômicos da decisão tomada de antemão.

Mais uma vez, valemo-nos das lições de Celso Fernandes CAMPILONGO:

\begin{abstract}
"Legislador e juiz enfatizam aspectos, técnicas, programas e etapas do processo decisório completamente distintos. Enquanto o legislador (e também o administrador) controla a própria agenda decisória, tem iniciativa na constituição dessa agenda e seleciona os temas sobre os quais deseja decidir, o juiz não tem nenhum controle sobre as causas que têm acesso ao Judiciário (e, como condição básica da sua imparcialidade, não pode ter nenhuma iniciativa na proposição de casos judiciais nem selecionar os temas submetidos à sua apreciação). Se o Legislativo pode escolher sobre o que decidir, o Judiciário não tem alternativas: deve sempre decidir todas as causas que lhe são apresentadas (non liquet). Isso explica a maior liberdade do sistema político no momento de definir os programas decisionais. Os limites impostos pelo ordenamento jurídico e pela Constituição ao processo decisório legislativo, excluídas as chamadas "cláusulas pétreas", são muito menores do que as restrições impostas ao juiz. Daí, igualmente a aproximação da justiça distributiva ao sistema político e das justiças comutativas e procedimental ao sistema jurídico" ${ }^{400}$.
\end{abstract}

Justamente em virtude desta diferenciação é que o problema do controle judicial das políticas públicas e regulatórias se coloca, tendo em vista que torna-se possível a utilização de demandas judiciais com a finalidade de pular etapas

\footnotetext{
${ }^{400}$ Política..., cit., p. 104.
} 
procedimentais do planejamento e execução de tais políticas, o que tende a causar transtornos dentro do sistema regulado, sobretudo ante a necessidade de reestruturação do planejamento feito.

\section{III.C.2 - O Problema Institucional de Quem Realiza a Política Regulatória}

Conforme já visto no presente trabalho, os atos normativos das agências reguladoras são os portadores da política regulatória, de tal forma que esta, a despeito de ser o fruto de uma análise econômica, política, técnica e jurídica, é expressada por meio de um ato normativo, o que permite e justifica o controle de juridicidade de tal atuação administrativa.

Diante disto, é possível afirmar, na linha de CARLOS ARI SundFELD e ANDRÉ RosILHO $^{401}$, que as políticas regulatórias se expressam por meio de normas e atos jurídicos, de modo que o DNA de tais políticas é escrito em código jurídico, o que implica numa relação de dependência entre elas e o Direito. Assim, sendo o código delas expresso por meio do direito, mostra-se possível "o controle da aplicação das políticas feito a partir de parâmetros jurídicos, isto é, para verificar sua conformidade com as normas jurídicas. Como se verá adiante, este fator pode ser determinante na definição de seus rumos e de suas características, bem como de sua paralisação ou continuidade" ${ }^{402}$.

No entanto, a despeito de se expressarem por atos jurídicos, tais políticas não são apenas jurídicas, pois congregam uma série de aspectos políticos, econômicos e técnicos, que são sopesados e valorados pelas agências reguladoras quando da formulação de tais políticas, tendo por finalidade o atendimento dos objetivos de cada setor regulado.

Conforme visto no capítulo II, do ponto de vista institucional, compete às agências reguladoras a função de desenvolver a moderna regulação econômica em um

\footnotetext{
${ }^{401}$ Direito e políticas públicas: dois mundos?, in Carlos Ari Sundfeld e André Rosilho (coords.) Direito da Regulação e Políticas Públicas, 2014, p. 48. Em tal texto, os autores tratam de políticas públicas, que, conforme afirmamos acima, parece-nos em muito semelhante com as políticas regulatórias, com as ressalvas feitas no presente trabalho.

${ }^{402}$ Idem, p. 49.
} 
cenário de abertura dos serviços públicos à prestação privada (republicização de atividades estatais) e, inclusive, em regime de competição entre os prestadores, de tal modo que a regulação deve ser exercida, consoante FlORIANO DE AZEVEDO MARQUES $\mathrm{NETO}^{403}$, (i) sem afastar a participação dos agentes privados do setor regulado; (ii) com a separação das tarefas de regulação e de exploração da atividade econômica, de tal modo que, ainda que haja ente estatal prestando o serviço, ele não pode ser ao mesmo tempo executor e regulador; (iii) com vistas à defesa dos interesses do cidadãos usuários dos serviços; (iv) com a finalidade de manter o equilíbrio interno do sistema regulado, de modo a permitir e estimular a concorrência, aliando esta aos objetivos distributivos e desenvolvimentistas; e (v) com a utilização de mecanismos menos impositivos e mais voltados à composição e arbitramento de interesses.

Para bem exercer tais funções, as normas criadoras das agências estipulam uma série de metas a serem observadas, o que as dota de uma discricionariedade em diversos campos de ação, que vai desde a escolha do momento de implementação de determinada diretriz regulatória, até o meio utilizado para tanto, o que implica em amplo campo para o exercício da discricionariedade regulatória.

Assim, a implementação de políticas regulatórias traz em si uma complexidade ímpar, que determina uma série de escolhas, inclusive políticas, que tendem a impedir que tais políticas sejam decorrência do mero silogismo fato-norma-consequência jurídica. Consoante ARTHUR SANCEZ BADIN, "a atividade de aplicação do direito, e em especial das normas de regulação dos mercados, não se resume à mera subsunção silogística de fatos à norma, como se supunha outrora. Elas implicam inúmeras escolhas, inclusive de políticas públicas. No próprio balanceamento dos princípios constitucionais encontram-se escolhas de valores e de prioridades" ${ }^{904}$.

Assim, a complexidade ínsita à regulação econômica hodierna gerou a necessidade de criação de entes reguladores altamente especializados e técnicos, uma vez que a implementação de políticas regulatórias não se dá pela mera execução de escolhas feitas a priori pelo legislador, mas sim de acordo com as finalidades setoriais e

\footnotetext{
${ }^{403}$ Agências reguladoras..., cit., p. 46.

${ }^{404}$ Controle..., cit., p. 91.
} 
as necessidades de conciliar evolução tecnológica, direitos dos usuários e interesses dos agentes econômicos.

Justamente em virtude da complexidade de tais escolhas é que foram criadas as agências reguladoras no direito brasileiro, dotadas de "ampla gama de competências associadas a uma alta especialização técnica, de modo a intervir num determinado setor da economia (cuja relevância ou essencialidade da atividade econômica justifiquem essa intervenção)" ${ }^{405}$.

Porém, o fato de as políticas regulatórias se expressarem por atos jurídicos, implica na possibilidade de haver o controle de tais atos pelo Poder Judiciário, tendo em vista que é a este que cabe dizer em última instância o que é o direito no caso concreto (justamente o significado de jurisdição), órgão este não dotado, ao menos inicialmente, de competência para instituir políticas regulatórias.

Assim, cria-se um sistema um tanto paradoxal, uma vez que a política regulatória será expedida por meio de ato jurídico, sendo possível o seu controle por meio de um órgão não incumbido de formular políticas e que possui por atribuição analisar apenas um dos aspectos da regulação, o jurídico, sendo, no entanto, que tal aspecto pode ser determinante para a continuidade ou paralisação da política regulatória.

Diante disto, (i) sendo o aspecto jurídico fundamental para as políticas regulatórias; (ii) sendo as agências entes especificamente criados para formular as complexas políticas regulatórias; e (iii) sendo o Judiciário o órgão de poder competente para o exercício da jurisdição (= juris dictio) em caráter definitivo, ou seja, sendo ele incumbido institucionalmente de decidir em caráter definitivo os conflitos de interesses (lides) que girem em tornos das normas jurídicas, o que inclui as normas regulatórias (incorporadoras das políticas regulatórias); a questão que se coloca é: sendo possível o controle judicial da política regulatória, quem, afinal, decide os rumos da regulação econômica?

${ }^{405}$ FloRIANO DE AZEVEDO MARQUES NETO, Agências reguladoras..., cit., p. 46. 
A resposta parece trivial e conduzir às agências reguladoras. No entanto, ao que nos parece, a questão ganha complexidade, tendo em vista que somente o Judiciário possui condições de afirmar quais os limites de suas atribuições enquanto órgão de revisão. Em outras palavras, a amplitude da cláusula da inafastabilidade da jurisdição somada à exteriorização das políticas regulatórias por meio de atos normativos, implica na colocação do Judiciário em uma posição um tanto privilegiada, tendo em vista que somente ele possui a competência para dizer qual o limite de sua atuação revisional sem invadir a esfera de atribuição das agências reguladoras.

Logo, ainda que do ponto de vista institucional caiba às agências reguladoras a estipulação das políticas regulatórias, a partir do momento em que o Judiciário é provocado a se manifestar a respeito de algum ato normativo regulatório, ele deve ter cautela na análise a ser feita, com a finalidade de não adentrar em aspectos que impliquem na supressão da competência regulatória da agência, com a avocação de tal competência pelo juiz.

Ou seja, é o Judiciário que decidirá quem decide a política regulatória, sem que contra tal ato haja qualquer recurso a outro poder, o que implica na análise criteriosa da postulação feita e dos efeitos da decisão judicial adotada, com a finalidade de preservar a competência institucional da agência de definir a política regulatória.

\section{III.D - Entre Ativismo Judicial e Leniência com o Abuso de Poder: o Controle Judicial da Atividade Normativa das Agências Reguladoras e seus Contornos Institucionais}

Diante dos problemas inerentes ao controle judicial dos atos normativos das agências reguladoras, surge a questão de se saber quais são os limites ao exercício de tal atividade jurisdicional.

O ponto que se coloca é justamente no sentido de evitar, de um lado, que o Judiciário acabe ultrapassando as fronteiras da sua função de tutela dos direitos e passe a se substituir ao regulador na atividade de ordenação de dado setor econômico e, de outro, que exercite um controle tímido da atividade administrativa, dando margem à concretização do abuso de poder por parte do administrador público, sob o auspício da 
prática de ato lícito e embasado em competência discricionária. Como se pudéssemos representar o controle judicial como um pêndulo, de um lado há o leniência com o abuso de poder, de outro o ativismo judicial e no centro, no ponto de equilíbrio, o controle judicial legitimamente realizado. A questão, então, é localizar o centro do pêndulo.

Assim, em nosso sentir, é necessário analisar tal atividade estatal de forma serena e que leve em consideração as funções institucionais do Judiciário e das agências reguladoras. Para tanto, vislumbramos duas formas de controle que incidirão sobre os atos normativos regulatórios: o controle incidente sobre a formalidade do processo regulatório e o controle a respeito do mérito do ato normativo regulatório.

\section{III.D.1 - O Controle Judicial sobre as Formalidades do Procedimento Regulatório}

O primeiro objeto de controle a respeito dos atos normativos regulatórios se refere ao controle do procedimento regulatório, o que implica na aferição pelo Judiciário da regularidade procedimental.

Conforme visto, a legitimidade da atividade normativa das agências reguladoras está justamente no procedimento que leva à expedição do ato regulatório, que deve ser um procedimento que tenha por característica a ampla participação dos interessados no setor regulado, com a finalidade de permitir a correta identificação dos diversos interesses em conflito e a ponderação entre eles para se verificar quais interesses deverão prevalecer no caso concreto.

Diante disto, entendemos que o principal foco da análise judicial no processo administrativo regulatório está na questão da efetiva participação dos interessados do setor regulado, o que inclui tanto os players que já atuam em tal mercado, quanto aqueles agentes que, a despeito de não participarem, possuam interesses que serão atingidos pela decisão normativa da agência reguladora.

Assim, deve ser analisado não apenas se houve a possibilidade de participação dos interessados, mas, mais do que isto, se tal participação foi efetiva, ou seja, se foi oportunizada a possibilidade de oferecimento de razões por escrito e elementos técnicos 
na defesa dos interesses dos participantes do processo, bem como se tais razões foram efetivamente analisadas pela agência durante o procedimento.

Dentro da sistemática do procedimento normativo que descrevemos no item II.B.2.2 do capítulo II, deve ser analisado se foi conferida a oportunidade de efetiva manifestação tanto quando das contribuições dos administrados na fase de análise do primeiro esboço de norma regulatória, quanto na análise das contribuições por ocasião da apresentação do segundo esboço pela agência.

E tal participação, que deve ser efetiva, não deve ser tratada pelo Judiciário como um mero favor por parte da Administração ou mesmo uma benesse ao particular. É simplesmente um corolário do direito ao contraditório e à ampla defesa, previstos constitucionalmente (artigo $5^{\circ}$, inciso LIV) e fonte da legitimidade do ato estatal, de tal forma que a ausência de participação efetiva (oportunidade de manifestação + efetiva apreciação da manifestação apresentada) implica em violação a tal garantia.

Outro aspecto que deve ser analisado quanto à formalidade procedimental se refere à existência de motivação do ato regulatório. Não integra o aspecto formal a análise a respeito da motivação em si, mas apenas a análise da existência de motivação nos autos. A verificação da motivação no que se refere à racionalidade, à existência de solução aos debates dos autos, a congruência dela em relação aos elementos dos autos e ao quanto decidido etc., será analisada sob o aspecto material do ato regulatório.

De outro lado, é possível que eventuais vícios procedimentais - desde que não ligados à participação efetiva, insistimos - sejam relevados, em situações nas quais eles efetivamente não afetarem a substância do processo e do ato normativo. Trata-se, como anota EGON BOCKMANN MOREIRA, do acolhimento da doutrina do pas de nullité sans grief, pela qual "a nulidade não deve ser decretada se não houver prejuízo real à parte que a alega. O sistema de nulidades processuais não pode ser compreendido em abstrato, como um fim em si mesmo, mas é construído na defesa do processo e das partes que nele interagem. Para sua aplicação exige a configuração de dano efetivo, que 
prejudique o processo em si ou seus sujeitos (Administração e particulares interessados) ${ }^{\prime 406}$.

Assim, por exemplo, a ausência de comunicação de dado ato à parte interessada pode ser suprida pelo comparecimento espontâneo dela aos autos; a publicação extemporânea de determinada decisão não possui o condão de anular o processo como um todo, caso o ato venha a ser publicado posteriormente sem prejuízo para os interessados etc.

\section{III.D.2 - O Controle Judicial com Relação ao Mérito do Ato Regulatório}

Além de recair sobre os aspectos procedimentais que deram origem ao ato normativo regulatório, é possível ao Judiciário também sindicar a validade do conteúdo material de tal ato, com a finalidade de verificar a adequação dele ao ordenamento jurídico.

A grande questão que se coloca, neste ponto, é a de saber quais os limites para tal controle, ou seja, até onde o Judiciário pode ir ao analisar a conformidade do ato normativo regulatório com o ordenamento.

\section{III.D.2.1 - Ainda a Questão do Controle Judicial do Mérito do Ato Administrativo}

A verificação dos limites ao controle judicial dos atos normativos das agências reguladoras nos coloca diante de um dos debates mais intensos do direito público brasileiro, que é o dos limites ao controle judicial do mérito do ato administrativo.

Com efeito, desde o momento em que MiguEl SEABRA FAGUNDES ${ }^{407}$ asseverou que o mérito do ato administrativo se cinge a um juízo político impossível de ser reanalisado pelo Poder Judiciário, que se limita aos aspectos de legalidade, aspectos estes que, no entanto, abrangem a análise das prescrições legais do ato administrativo, a

\footnotetext{
${ }^{406}$ Processo administrativo..., cit., p. 217.

${ }^{407}$ O controle..., cit., p. 179 e segs. Vale lembrar, aqui, que a primeira edição de tal obra foi publicada em 1941.
} 
competência, o motivo, o objeto, a finalidade e a forma, o tema do controle da discricionariedade administrativa ganhou fôlego no direito brasileiro.

Desde aquela época (início dos anos 40 do século passado), o tema tem chamado cada vez mais a atenção dos publicistas, notadamente no que se refere (i) à distinção entre a discricionariedade e o abuso de poder, notadamente sob a vertente do desvio de finalidade; (ii) aos padrões de juridicidade a que se submete a Administração, ante a normatividade principiológica e à doutrina dos direitos fundamentais; e (iii) relacionados a estes dois temas, os limites do controle judicial da discricionariedade administrativa.

A primeira vertente acima apontada (distinção entre discricionariedade e abuso de poder) é a mais antiga no direito administrativo nacional, sendo decorrência das considerações de Miguel SEABRA Fagundes já mencionadas e da própria tradição autoritária do Estado brasileiro, de tal forma que se justifica historicamente como o principal ponto de estudo e reflexão a respeito da discricionariedade administrativa.

Para esta corrente, as questões afetas à motivação ${ }^{408}$ e à finalidade ${ }^{409}$ do ato administrativo são questões de legalidade, que não se confundem com o mérito do ato administrativo, de tal forma que cabe ao Judiciário realizar a análise do ato

\footnotetext{
${ }^{408}$ Ao tratar do controle judicial da motivação, MiguEl SEABRA FAGUNDES realizou a análise da possibilidade de revisão judicial das provas colhidas em inquéritos administrativos instaurados para a punição disciplinar de servidores público, com a finalidade de averiguar não apenas os aspectos formais do inquérito, mas também a conformidade da penalidade imposta com aquilo que foi apurado no procedimento investigativo. "Conquanto a demissão se processe no âmbito interno da Administração Pública, que apura a falta e aplica a penalidade, uma vez levado o ato ao conhecimento do Poder Judiciário, os tribunais entram no exame do inquérito, fundamento da medida, quer para constatar se foi feito como manda a lei, quer para aferir a conformidade do ato com o que se apurou no processo. A primeira questão é manifestamente de legalidade, a segunda, entretanto, poderá parecer de mérito. Mas não é. O Judiciário se limita a verificar se o processo administrativo apurou um dos motivos dados pela lei como capazes de justificar a exoneração de funcionário". (O controle..., cit., p. 182-183, nota de rodapé 127).

409 "A finalidade do ato é examinada como aspecto da legalidade, tendo-se em vista verificar se a Administração Pública agiu ou não com o fim previsto na lei. Indaga-se da finalidade para apurar se o ato administrativo foi praticado para alcançar o fim desejado pelo texto legal. A desvirtuação de finalidade (détournement de pouvoir do direito francês) pode tornar o ato ilegal. Aqui o exame da legalidade quase chega ao mérito. Há, porém, um sutil limite que se não deve esquecer. $O$ julgamento examina se o ato se conteve dentro do poder do administrador, isto é, se foi praticado segundo os fins, em virtude dos quais o poder de agir the foi outorgado pela lei, mas não se o uso que fez do poder foi o melhor. Enquanto se discute se o fim do ato foi o querido pela lei, há uma simples questão de legitimidade. Só haveria exame do mérito, se se quisesse discutir o acerto do ato pelo bom uso da competência, em face das necessidades coletivas" (MiguEL SeABRA FAGUNDES, O controle..., cit., p. 190, nota de roda-pé 128).
} 
administrativo exarado no exercício de competência discricionária, também por estes aspectos e não apenas pelos aspectos externos do ato (competência, objeto e forma).

Assim, a partir da década de 40, o Judiciário passou a exercer controle sobre a motivação dos atos de demissão dos funcionários públicos - já àquela época tidos como discricionários -, com a finalidade de aferir a respeito da coerência entre o que fora apurado e o quanto decidido ${ }^{410}$.

Nesta linha, ao julgar a Apelação Cível n 7.307, o Supremo Tribunal Federal asseverou a possibilidade de serem reanalisadas as provas produzidas no inquérito instaurado para a apuração funcional e demissão do servidor, bem como que novas provas pudessem ser produzidas em juízo ${ }^{411}$, com a finalidade de averiguar se houve ou não a ocorrência dos motivos que ensejariam a demissão do funcionário.

Ao analisar tal acórdão, Victor Nunes LEAL asseverou que “A 'legalidade’ do ato administrativo compreende, não só a competência para a prática do ato e as suas formalidades extrínsecas, como também os seus requisitos substanciais, os seus motivos, os seus pressupostos de direito e de fato (desde que tais elementos estejam definidos em lei como vinculadores do ato administrativo", de tal forma que "A inconformidade do ato com os fatos que a lei declara pressupostos dêle constitui ilegalidade, do mesmo modo que o constitui a forma inadequada que o ato porventura apresente" ${ }^{412}$.

Esta primeira vertente possui o grande mérito de tentar estipular uma diferença entre a discricionariedade, entendida como manifestação legítima da Administração calcada na legalidade, e o abuso de poder, que "surge com a violação da legalidade, pela qual se rompe o equilíbrio da ordem jurídica. Tanto da legalidade externa do ato

\footnotetext{
${ }^{410}$ A respeito da evolução do controle judicial da Administração no Brasil, cf. PAULO MAGALHÃES DA Costa COElHo, Controle jurisdicional da administração pública, 2002, p. 42 e segs.

${ }^{411}$ VICTOR NUNES LEAL, Os atos administrativos perante o Judiciário, in Público, 1960, p. 256 e segs.

${ }^{412}$ Op. cit., p. 264. Temas de Direito
} 
administrativo (competência, forma prevista ou não proibida em lei, objeto lícito) como da legalidade interna (existência dos motivos, finalidade)"413.

Aponta Oswaldo Aranha BAndeIRA DE MEllo que, enquanto a discricionariedade administrativa se refere a "atividade circunscrita dentro de limites jurídicos", a arbitrariedade se manifesta pela atividade "sem limites jurídicos, em que o agente atua segundo seu exclusivo critério" ${ }^{414}$, o que é inadmissível no Estado de Direito. Continua referido autor a asseverar que os limites à discricionariedade estão expressos na motivação e na finalidade pública que o ato deve perseguir.

O grande mérito dos administrativistas de tal período - meados do século passado - foi o de conceber uma teoria jurídica que permitisse ao Judiciário o controle de dois aspectos capitais para a aferição do desvio de finalidade: a motivação e a finalidade legal do ato.

Mais recentemente, tal corrente foi complementada por autores que passaram a entender ser possível o controle judicial da discricionariedade administrativa de acordo com os princípios aplicáveis à Administração, o que implica em maior restrição às escolhas feitas pelo administrador.

Neste sentido, aponta MARIA SYlVia ZANElla Di PIETRO ${ }^{415}$, que na atualidade servem como parâmetros se limitação da discricionariedade, uma vez que possibilitam o controle judicial da atividade administrativa: (i) a constitucionalização de princípios e valores integrantes do sentido amplo de legalidade administrativa; (ii) a existência de uma efetividade mínima nas normas constitucionais de direitos sociais, que deixam de ser consideradas totalmente programáticas, o que lhes conferiu a possibilidade de exigibilidade judicial; (iii) o entendimento de que o conceitos jurídicos indeterminados podem ser objeto de interpretação judicial, de modo que nem sempre constituir-se-ão em efetivamente opções discricionárias para a Administração.

\footnotetext{
${ }^{413}$ CAIO TÁCITO, O abuso de poder administrativo no Brasil (conceito e remédios), 1959, p. 29.

${ }^{414}$ Princípios gerais..., cit., p. 473.

${ }^{415}$ Discricionariedade administrativa..., cit., p. 46-47.
} 
Na mesma linha, Celso Antônio BAndeIRA DE Mello também entende incidirem como limitadores da discricionariedade administrativa os princípios a que se submete a Administração Pública, principalmente os princípios da razoabilidade e proporcionalidade. Afirma o autor que "não se poderiam admitir medidas desproporcionadas em relação às circunstâncias que suscitaram o ato - e, portanto, assintônicas com o fim legal - não apenas porque conduta desproporcional é, em si mesma, comportamento desarrazoado, mas também porque representaria um extravasamento da competência" ${ }^{416}$.

Trata-se, aqui, de uma ampliação dos parâmetros de juridicidade da atuação administrativa, o que implica no aumento da base sobre a qual incidirá o controle judicial da discricionariedade. Não se trata, obviamente, de extinguir a discricionariedade administrativa enquanto instituto, mas sim de analisar se efetivamente o caso concreto, visto à luz dos fatos em julgamento e das regras e princípios incidentes, ainda contemplava algum tipo de escolha administrativa ou não.

Em virtude de tais novos parâmetros de juridicidade, Gustavo BinENBOJM assevera que não se deve mais falar em dicotomia atos vinculado e ato discricionário, mas sim em graus de vinculação do ato administrativo à juridicidade, de acordo com uma escala de vinculação normativa. Nas palavras do autor:

\footnotetext{
“O mérito - núcleo do ato -, antes intocável, passa a sofrer a incidência direta dos princípios constitucionais. Deste modo, ao invés de uma dicotomia em moldes tradicionais (ato vinculado $v$. ato discricionário), já superada, passa-se a uma classificação em graus de vinculação à juridicidade, em uma escala decrescente de densidade normativa vinculativa:

a) atos vinculados por regras (constitucionais, legais ou regulamentares);

b) atos vinculados por conceitos jurídicos indeterminados (constitucionais, legais ou regulamentares);

c) atos vinculados diretamente por princípios (constitucionais, legais ou regulamentares)" ${ }^{\prime 17}$.
}

Assim, mostra-se plenamente possível o controle do mérito do ato administrativo, com a finalidade de se assegurar a sua conformação ao ordenamento jurídico, como meio de se evitar o abuso de poder e o desvio de finalidade, sob as

\footnotetext{
${ }^{416}$ Discricionariedade..., cit., p. 97.

${ }^{417}$ Uma teoria do direito administrativo: direitos fundamentais, democracia e constitucionalização, $2^{a}$ ed., 2008, p. 209-210.
} 
formas de atos tidos como discricionários. De acordo com PAUlo MagalHães DA Costa Coelho:

"Cuida-se apenas de verificar se, na sua atuação concretizadora da finalidade da lei, a administração pública está não só respeitando como ainda implementando os vetores axiológicos do ordenamento jurídico. O que não se pode pretender, à evidência, é que, ao exercer faculdades discricionárias, possa ela se colocar ao abrigo do controle da principiologia constitucional, que deve ser levada a efeito, até suas últimas consequências, pelo Poder Judiciário, que, ao agir assim, estará apenas e tão-somente cumprindo sua missão constitucional. Nem se pretenda que, ao fazê-lo, estará a invadir o 'mérito' do ato administrativo. Fazer valer os vetores constitucionais é tarefa imperiosa do Poder Judiciário, que não pode se acovardar a pretexto de invasão de competência de outro poder" ${ }^{118}$.

Logo, em nossa opinião, não cabe mais a discussão se o Judiciário pode ou não sindicar o mérito do ato administrativo, com a finalidade de verificar a sua juridicidade, mas sim, como deve ser realizado este controle. Assim, não cabe mais a pergunta se é possível o controle judicial do mérito, mas como deve ele ser feito.

\section{III.D.2.2 - Um Importante Parâmetro do Direito Estrangeiro: A Hardlook Doctrine}

No direito norte-americano, a questão do controle judicial da Administração passa obrigatoriamente pelo controle das agências reguladoras, o que aproxima de nosso trabalho a verificação dos parâmetros utilizados pelo Judiciário dos Estados Unidos para revisar os atos de tais entes.

Um importante método utilizado pelo Judiciário norte-americano para realizar o controle da atividade normativa das agências reguladoras é o que se denominou de hard look review, pelo qual os juízes analisam tanto aspectos procedimentais, quanto materiais dos atos das agências reguladoras.

Mais do que fazer aqui uma reconstituição histórica da construção desta doutrina pela Suprema Corte norte-americana ${ }^{419}$, o que nos interessa para os fins do presente trabalho é verificar quais são os aspectos substanciais que emergem dela e como podem ser aproveitados pelo direito brasileiro.

\footnotetext{
${ }^{418}$ Controle jurisdicional..., cit., p. 54.

${ }^{419}$ Para uma profunda análise do histórico de evolução da hard look doctrine, cf. STEPHEN G. BREYER et alli, Administrative law..., cit., p. 386 e segs; e SERGIO VARELla BRUNA, Agências reguladoras..., cit., p. 221 e segs.
} 
Conforme aponta Sergio Varella Bruna, tal doutrina de controle possui um aspecto híbrido, pois conjuga as exigências do devido processo legal adjetivo e substantivo, sendo que, ao lado da análise dos aspectos processuais da atuação da agência, o Judiciário também verifica a razoabilidade da medida tomada, em uma “abordagem mais objetiva, orientada pelos princípios estabelecidos pelo próprio legislador para o exercício das competências legais atribuídas à autoridade administrativa" ${ }^{420}$.

No aspecto processual, a hard look doctrine impõe às agências o dever de considerar todos os interesses envolvidos na questão a ser regulada, sem que o administrador possa decidir à margem de fatores relevantes, que são levados ao processo pelas partes ${ }^{421}$. Ademais, tal doutrina demanda que as agências possuam a maior quantidade de dados possível a respeito do processo de regulação (rule-making record), com a finalidade de verificar se as demandas dos diversos grupos foram devidamente respondidas, bem como os elementos e fatos apurados no procedimento ${ }^{422}$.

No entanto, se o aspecto processual é relevante, o aspecto material mostra-se de maior valia para a finalidade de se tentar invalidar os atos desarrazoados e que sejam praticados de modo abusivo ou caprichoso. Neste passo, para que o ato da agência reguladora seja válido, ele deve (i) estar de acordo com os elementos dos autos do processo administrativo e (ii) ser razoável, "em vista dos elementos dos autos constantes dos autos administrativos e de sua confrontação com as finalidades legais a atingir" ${ }^{" 23}$, de tal forma que o Judiciário tem considerado ilegítimas as medidas regulatórias consideradas caprichosas e arbitrárias, o que, no Brasil, pode ser considerado como sinônimo de regulação desarrazoada ou desproporcional.

Além disto, o Judiciário tem exigido que as agências levem em consideração todas as questões significantes, não apenas aquelas significantes levadas aos autos pelas

\footnotetext{
${ }^{420}$ Agências reguladoras..., cit., p. 233.

${ }^{421}$ Este aspecto processual foi ressaltado no caso Overton Park, de 1971.

${ }^{422}$ MARTIN SHAPIRO, Who guards the guardians? Judicial control of administration, 1988, p. 53.

${ }^{423}$ Sergio VArella Bruna, Agências reguladoras..., cit., p. 225.
} 
partes, mas todas as questões relevantes, o que inclui as questões de custo-benefício da medida regulatória ${ }^{424}$.

Em suma, tal doutrina implica na possibilidade de revisão judicial do ato normativo regulatório, tendo em vista os elementos existentes nos autos do processo administrativo, de tal forma que MARTIN SHAPIRO afirma serem as agências e o Judiciário "parceiros" nesta análise mais detalhada e aprofundada do processo. No entanto, afirma o autor, que as cortes possuem uma posição privilegiada, tendo em vista que, de um lado, possuem a última palavra quão aprofundada e detalhada deve ser a análise da agência em cada processo normativo e, de outro lado, decidem de modo soberano não apenas se as agências adotaram o procedimento normativo correto, mas também se editaram a norma substantivamente correta. Assim, ante tal doutrina, as agências acabam por possuir o dever de convencer os tribunais de que elas fizeram substancialmente a melhor política ${ }^{425}$.

Outra característica relevante de tal doutrina se refere aos efeitos da decisão judicial sobre o ato normativo considerado por alguma razão ilegal. Em regra, o tribunal não considera a escolha feita pela agência como irremediável, mas apenas assevera que a agência não justificou adequadamente as suas escolhas, ainda que a justificativa para a reprovação judicial seja o caráter arbitrário ou caprichoso da medida adotada. Assim, os tribunais costumeiramente reencaminham o procedimento para a agência envolvida no caso, com a finalidade de que ela possa reforçar a política que pretende adotar, por meio de uma análise mais extensiva e com maior esclarecimento de acordo com o processo ${ }^{426}$.

\section{III.D.2.3 - A Hard Look Doctrine e sua Aplicabilidade no Direito Brasileiro}

Feita esta breve análise a respeito da hard look doctrine, resta-nos saber se ela é aplicável ao direito brasileiro e em que medida ela pode ser proveitosa para o controle dos atos normativos das agências reguladoras.

\footnotetext{
${ }^{424}$ MARTIN SHAPIRO, Who guards the guardians?..., cit., p. 52-53 e 72-73.

${ }^{425}$ Idem, p. 53-54.

${ }^{426}$ STEPHEN G. BREYER et alli, Administrative law..., cit., p. 386-387.
} 
Em nosso sentir, ela pode ser válida para a construção dogmática do controle judicial dos atos normativos das agências reguladoras no Brasil, com base em dois aspectos verificados no item anterior ${ }^{427}$, quais sejam (i) o controle material da regulação conforme os elementos do procedimento; e (ii) o resultado do controle judicial realizado. Tais elementos serão analisados a seguir.

\section{III.D.2.3.1 - O Controle Material da Regulação de Acordo com os Elementos do Procedimento Administrativo e com os Princípios e Postulados Incidentes Sobre a} Regulação

Conforme verificado, a doutrina norte-americana da hard look review permite que o Judiciário analise os aspectos substanciais do ato regulatório, em conformidade com os elementos do procedimento administrativo. Assim, em nosso sentir, tal doutrina coloca a possibilidade de o Judiciário exercer ampla sindicabilidade da medida regulatória, sem esbarrar no simplório argumento de que se trata de medida de caráter técnico e, portanto, infensa ao controle judicial.

Dessa forma, parece-nos que do ponto de vista do controle material da regulação ganham relevância a aferição judicial que recaia sobre (i) a motivação do ato regulatório e (ii) os parâmetros de eficiência, subsidiariedade, razoabilidade e proporcionalidade da atuação regulatória.

No que se refere à motivação, do ato regulatório - já analisada sob o aspecto formal -, impõe-se que o Judiciário analise-a não apenas no aspecto da existência de motivação, mas sim da qualidade da motivação fornecida pela agência reguladora, ou seja, quanto aos próprios aspectos da fundamentação.

Neste passo, deve ser verificado se a motivação analisou todos os elementos do processo administrativo regulatório, notadamente as manifestações fornecidas pelos interessados, com a finalidade de aferir se houve ou não interessados preteridos pela Administração no procedimento regulatório, bem como se os elementos dos autos foram devidamente sopesados pela autoridade que tomou a decisão.

\footnotetext{
${ }^{427}$ A questão atinente ao controle procedimental, que seria o terceiro aspecto, já foi analisada no item III.D. 1 acima.
} 
Aqui, não se trata de substituir o juízo técnico da agência pelo do Judiciário, mas apenas de analisar se efetivamente a justificativa técnica fornecida pela agência decorre dos elementos dos autos e, mais, se o ato normativo editado possui congruência com a motivação fornecida.

Também deverá o Judiciário analisar se a motivação possui uma lógica interna, ou seja, se pela leitura dela é possível compreender quais foram os debates ocorridos no procedimento, quais os elementos técnicos e fáticos sopesados, bem como se dos debates e elementos decorre logicamente a conclusão tomada pela agência.

Com base nesta análise da motivação, entendemos que o Judiciário poderá exercer um completo controle a respeito dos fundamentos fornecidos pela Administração na decisão, com a finalidade de aferir a sua racionalidade e a sua completude de acordo com o quanto apurado nos autos. Justamente por esta razão é que colocamos tal análise nesta parte do trabalho que se refere ao mérito, pois entendemos que a análise detida da motivação e seus aspectos internos implica não análise dos aspectos formais, mas sim de seus aspectos materiais.

No que se refere ao controle judicial sobre os parâmetros de subsidiariedade, eficiência, razoabilidade e proporcionalidade, também entendemos que não deverá haver timidez do Judiciário em analisar tais questões, sob o argumento de que se constituiriam em matérias discricionárias, o que, conforme visto, de modo algum elide o controle judicial.

O primeiro dos aspectos acima apontados se refere à subsidiariedade da intervenção regulatória estatal. Neste ponto, desde que devidamente provocado para tanto, o Judiciário deverá analisar se a medida regulatória se mostra desnecessária em relação à atuação satisfatória dos agentes prestadores dos serviços no sistema regulado na efetivação dos direitos fundamentais.

Conforme visto no capítulo anterior, a intervenção regulatória estatal possui como pressuposto a insuficiência dos agentes privados para atingir os objetivos de interesse coletivo do sistema no qual se insere o mercado. Dessa forma, se os próprios 
agentes do mercado puderem atender às finalidades legais sem a necessidade de intervenção estatal regulatória, inexiste razão para que seja expedido o ato regulador.

Em ocorrendo situação como esta, de desnecessidade da intervenção estatal, haverá a possibilidade de provocação do Judiciário para sustar a medida regulatória, ante a afronta ao princípio da subsidiariedade.

No que se refere aos padrões de eficiência da medida regulatória, entendemos também ser possível o controle judicial da regulação, caso reste demonstrado que a medida regulatória adotada não atende minimamente a parâmetros de eficiência administrativa, aqui entendida como a eficiência do setor regulado.

É dizer, mostra-se possível que o controle judicial analise se a medida adotada é eficiente para o atendimento às finalidades do setor regulado, de acordo com a lei que instituiu o marco regulatório, bem como se é eficiente no sentido de tutelar os direitos dos usuários do setor.

O padrão de eficiência a ser analisado é o da eficiência mínima, ou seja, não nos parece que o Judiciário deva analisar se a medida adotada foi a melhor dentre aquelas que se apresentavam ao regulador - até porque isto representaria substituir o juízo da agência pelo do magistrado -, mas sim se a medida se apresentava, à época da decisão, minimamente apta a gerar eficiência ao setor regulado.

No que se refere ao controle pela via dos postulados da razoabilidade e proporcionalidade deve ser analisado pelo Judiciário se a medida regulatória foi proporcional e razoável dentro do sistema regulado, de acordo com as finalidades e com os interesses em jogo quando da normatização pela agência.

Assim, deve o Judiciário analisar se a medida regulatória restringiu em demasia ou não os direitos dos agentes do subsistema regulado, bem como se há pertinência lógica entre a restrição imposta e a finalidade que se pretende alcançar com tal medida. 


\section{III.D.2.3.2 - O Resultado do Controle Material da Regulação}

Em terceiro lugar, tal doutrina não permite que o Judiciário se substitua no papel do regulador, ou seja, não existe permissão para que o juiz exerça um papel ativo, no sentido de dizer ao regulador qual a opção que deveria ter adotado. Em nosso sentir, tal doutrina procede e deve ser adotada no direito brasileiro.

Conforme já exposto no presente trabalho, as agências reguladoras foram criadas com a finalidade de regular os setores econômicos e sociais específicos, de acordo com os interesses e finalidades de cada um destes setores. Apesar de isto parecer obviedade - e, de fato, é -, para o estudo do controle judicial da regulação tal informação traz um dado bastante significante no que se refere aos limites impostos ao Judiciário na análise das normas regulatórias.

É que a existência de entidades institucionalmente dotadas de competência regulatória implica na impossibilidade de o Judiciário se substituir ao regulador. Aqui, a questão, em nosso sentir, não é solucionada pela ausência de conhecimentos técnicos dos magistrados - como dos operadores do Direito em geral - em relação às matérias reguladas. Até mesmo porque, a ausência de conhecimentos técnicos das matérias reguladas poderia ser suprida seja pela apresentação de elementos técnicos pelas partes, seja pelo aparelhamento do Judiciário com técnicos de diversos setores, sejam eles peritos ou mesmo servidores concursados em diversas áreas do conhecimento (engenharia, economia, telecomunicações etc. $)^{428}$.

A nosso ver, a impossibilidade do Judiciário se substituir ao regulador na determinação de qual a política regulatória a ser seguida decorre de uma questão institucional, ou seja, da atribuição a entes específicos da competência para a regulação de setores específicos, de acordo com leis setoriais específicas. Em suma, não compete ao Judiciário estipular os padrões e a política regulatória dos setores regulados, o que impede que ele venha a substituir o regulador setorial.

\footnotetext{
${ }^{428}$ Como ocorre, por exemplo, nos Tribunais de Contas que possuem Assessorias Técnicas em diversas áreas do conhecimento, como engenharia e economia, ou mesmo no Ministério Público, com órgãos especializados para a realização de cálculos e perícias de engenharia para a instrução de inquéritos civis e outros procedimentos investigatórios.
} 
Assim, diante da prática de um ato normativo tido como ilegal, o Judiciário, em nosso sentir, somente pode anulá-lo, ou seja, praticar um controle negativo sobre o ato, sem, determinar à agência qual seria a solução correta ${ }^{429}$, tendo em vista que, além de não ser competência judicial a estipulação do conteúdo do ato regulador, pode ser que, quando da decisão judicial, o contexto do sistema regulado haja se alterado, o que implicará em tomada de decisão totalmente impertinente para o sistema regulado.

No entanto, isto não significa, nem de longe, que o controle judicial da regulação esteja impossibilitado. Pelo contrário, conforme expusemos acima, compete ao Judiciário analisar tanto os aspectos processuais, quanto materiais do ato normativo regulador, com a finalidade de evitar que haja lesão ou ameaça a direitos de todos os envolvidos no setor regulado.

Para tanto, pode ser feito um controle sobre o próprio mérito do ato regulatório, com a finalidade de que se analise a racionalidade da motivação, sua completude e congruência, bem como a verificação do atendimento aos princípios da subsidiariedade, eficiência, razoabilidade e proporcionalidade.

No que toca a estes elementos (princípios e postulados), a cautela do controle se apresenta entre a deferência ao juízo formulado pela agência e a impossibilidade de substituição deste pelo juízo formulado pelo Judiciário. Ou seja, se não é permitido ao Judiciário substituir o regulador, parece-nos que também não estará ele cumprindo seu papel institucional com uma postura retraída o bastante a ponto de não analisar as questões de razoabilidade e proporcionalidade que são submetidas.

O que queremos deixar expresso é que nos parece possível que o Judiciário adentre o mérito do ato regulatório, com a finalidade de aferir se houve violações a direitos e se foram respeitados os princípios e postulados do setor regulado, com vistas à finalidade legal de cada um deles.

429429 Em sentido contrário, entendendo possível o controle positivo do Judiciário, nos casos em que a norma possibilitar antever apenas uma solução legítima, cf. AlEXAndre SANTOS DE ARAGÃo, Agências reguladoras...cit., p. 353. 
Neste passo, caso o processo judicial demonstre que a agência observou os parâmetros que deveria, com regular procedimento prévio, no qual todos os interessados participaram e foram devidamente ouvidos, com suas contribuições sopesadas pela agência no momento da decisão, bem como que a decisão chegou a uma solução eficiente, razoável e proporcional, dentre as alternativas possíveis - não a melhor solução, mas a solução possível -, não nos parece possível que o Judiciário possa anular o ato ou mesmo substituir a opção do regulador pela sua própria. Cabe-lhe, então, a deferência ao que fora decidido pela agência, o que tem sido feito com a finalidade de manter o equilíbrio e a estabilidade dos setores regulados ${ }^{430}$.

\footnotetext{
${ }^{430}$ Neste sentido, importantes os seguintes julgados dos tribunais pátrios:

"PROCESSUAL CIVIL. SISTEMA DE TELEFONIA PRÉ-PAGO. VALIDADE DOS CRÉDITOS. MEDIDA CAUTELAR. EFEITO SUSPENSIVO. RECURSO ESPECIAL. CONJUGAÇÃO DOS PRESSUPOSTOS DE CONCESSÃO DA LIMINAR.

I - O agravante postula a reforma da decisão que indeferiu a liminar que buscava atribuir efeito suspensivo ao recurso especial interposto contra o acórdão que viabilizou tutela antecipada para acabar com a prescrição dos créditos do sistema de celulares pré-pagos.

II - Entendo relevantes os argumentos lançados pelo requerente, pelo que se dessume que, para a execução do acórdão infirmado pelo recurso especial vinculado, far-se-ia necessária uma alteração no sistema técnico implantado, o qual implicaria em efetivo prejuízo para a parte em face mesmo da mudança no planejamento, que segundo o requerente implica em investimentos da ordem de $\mathrm{R} \$$ 16.000,000,00 (dezesseis milhões de reais) para os próximos dois anos.

III - Nesse diapasão, estaria mesmo caracterizada lesão irreparável para o requerente, tendo em vista que, in casu, o acórdão que ampara a tutela antecipada tem natureza provisória pendente de confirmação no juízo ordinário, sem falar dos recursos aplicáveis, e a reversibilidade da implantação de nova tecnologia para permitir a utilização dos créditos para período indeterminado importaria em maior prejuízo para a companhia requerente.

IV - Além da análise encimada observe-se ainda que os valores não auferidos pelo requerente dificilmente seriam recompostos em face da natureza do sistema pré-pago.

V - Agravo regimental provido".

(STJ - $1^{\text {a }}$ Turma, AgRg na MC 10.443/PB, Rel. Min. Francisco Falcão, j. 13/12/2005.)
}

"RECURSO ESPECIAL DA TELEPAR BRASIL TELECOM S/A - ADMINISTRATIVO - AÇÃO CIVIL PÚBLICA - AUSÊNCIA DE PREQUESTIONAMENTO - PRELIMINARES NÃOACOLHIDAS - SERVIÇO DE TELECOMUNICAÇÕES - LEI N. 9.472/97 - ATRIBUIÇÃO À ANATEL PARA ESTABELECER A ESTRUTURA TARIFÁRIA - RESOLUÇÃO 85/98 - CONCEITO DE ÁREA LOCAL DEFINIDO DE ACORDO COM CRITÉRIOS TÉCNICOS E ECONÔMICOS TARIFA DE LIGAÇÃO INTERURBANA INCIDENTE SOBRE LIGAÇÕES INTRAMUNICIPAIS IMPOSSIBILIDADE, NO CASO CONCRETO, DO PODER JUDICIÁRIO ADENTRAR NO MÉRITO DO ATO ADMINISTRATIVO - VIOLAÇÃO DO PRINCÍPIO DA SEPARAÇÃO DOS PODERES E DISPOSIÇÕES DA LEI N. 9472/97. PRECEDENTES DAS PRIMEIRA E SEGUNDA TURMAS.

1. Não viola o artigo 535 do CPC o julgado que decide de forma clara e objetiva acerca do ponto alegado como omisso, ainda que de forma contrária à pretensão do recorrente.

2. O julgamento antecipado da lide não ocasiona cerceamento de defesa quando o Juízo entende que não há mais controvérsia quanto aos fatos nucleares da demanda, restando apenas o deslinde das questões de direito.

3. O pedido deve ser interpretado em consonância com a pretensão deduzida na exordial como um todo, sendo certo que o acolhimento do pedido extraído da interpretação lógico-sistemática da peça inicial não implica em julgamento extra-petita.

4. As circunstâncias fáticas podem reduzir a margem de discricionariedade do administrador, ou até eliminá-la, de modo que, quando este age em desconformidade com a finalidade legal, é possível ao 
O que não nos parece possível é que o Judiciário deixe de efetuar um controle mais robusto a respeito do ato regulatório, simplesmente por considerar que sendo ele portador de "discricionariedade técnica", mostra-se impossível o controle judicial. Isto,

Poder Judiciário substituí-lo e tomar a decisão que se ajusta à vontade da lei, sem que isto constitua violação do princípio da separação dos Poderes.

5. In casu, todavia, há dúvidas insuperáveis quanto à legalidade da atuação do agente público na escolha dos critérios que definiram o conceito de área local, e que permitiu, no caso dos autos, que localidades diversas, ainda que dentro do mesmo município, em razão de fatores técnicos e econômicos, pudessem sofrer tarifação de ligações interurbanas.

6. É na dúvida, na zona onde não se pode emitir um juízo de certeza, que reside o mérito do ato administrativo discricionário e que cabe ao administrador público, e somente a ele, agir para encontrar o caminho que melhor atenda à finalidade legal. Sendo assim, na situação dos autos, ao adentrar no mérito das normas e procedimentos regulatórios que inspiraram a configuração das "áreas locais", o Tribunal de origem invadiu seara atribuída à administração pública, atitude esta que ultrapassou os limites impostos pelo princípio da separação dos Poderes e violou as disposições da Lei n. 9472/97”.

(STJ - 2 ${ }^{\text {a }}$ Turma, REsp 973.686/PR, Rel. Min. Humberto Martins, j. 15/09/2009)

"CONSTITUCIONAL. ADMINISTRATIVO. ANS - AGÊNCIA NACIONAL DE SAÚDE SUPLEMENTAR. AGÊNCIA REGULADORA. PODER NORMATIVO. LEIS $\mathrm{N}^{\circ} \mathrm{s}$ 9.661/2000 E 9.656/1998. RESOLUÇÃO NORMATIVA ANS N¹67/2008. ROL DE REFERÊNCIA BÁSICA. COBERTURA DE TRANSPLANTES DE FÍGADO, CORAÇÃO E DEMAIS ÓRGÃOS. PLANOS DE SAÚDE. APELAÇÕES PROVIDAS. 1. Sentença que determinou à ANS que complementasse o rol de procedimentos previstos na Resolução Normativa $n^{\circ} 167 / 2008$, pertinente ao plano de referência, inserindo os procedimentos e eventos de saúde relativos ao transplante de fígado, coração e demais órgãos. 2. A despeito de a Constituição ter erigido a saúde como dever do Estado, também assegurou a prestação de serviços de saúde por meio de instituições privadas (art. 199), cabendo ao Poder Público dispor, nos termos da lei, sobre sua regulamentação, fiscalização e controle. Nos termos da Lei 9.961/2000, foi criada a Agência Nacional de Saúde Suplementar - ANS, autarquia especial, vinculada ao Ministério da Saúde, para fins de atuação no papel de promoção do interesse público na assistência suplementar à saúde, regulando as operadoras setoriais, inclusive quanto às suas relações com prestadores e consumidores, contribuindo para o desenvolvimento das ações de saúde no País. 3. Nos moldes do art. $4^{\text {o }}$, III da Lei 9.961/2000 cabe à ANS - Agência Nacional de Saúde Suplementar a competência para "elaborar o rol de procedimentos e eventos em saúde, que constituirão referência básica para os fins do disposto na Lei $n^{\circ}$ 9.656, de 3 de junho de 1998 e suas excepcionalidades". 4. A Resolução Normativa ANS n. ${ }^{\circ}$ 167/07, atualizou o rol básico de procedimentos e eventos de saúde, ampliando coberturas para os beneficiários de planos de saúde, cujo atendimento é obrigatório para todos estes. O rol básico teve o objetivo de estabelecer uma cobertura de procedimentos médico-hospitalares mínima e suficientemente ampla, mas que não comprometesse desmedidamente as finanças dos planos de saúde, acarretando um aumento conseqüente no preço pago pelos particulares, o que inviabilizaria a prestação privada da saúde, e ao mesmo tempo traria uma acréscimo comprometedor ao tão sobrecarregado sistema único de saúde. 5. Apresenta-se inviável para o equilíbrio financeiro e atuarial dos planos de saúde a cobertura integral e irrestrita, tanto assim que o art. 10 da Lei $n^{\circ}$ 9.656/98, ao fazer a previsão de plano de referência de assistência à saúde,excluiu expressamente alguns procedimentos. 6. No parágrafo $4^{\circ}$ do referido artigo existe previsão expressa no sentido de que "A amplitude das coberturas, inclusive de transplantes e de procedimentos de alta complexidade, será definida por normas editadas pela ANS". Assim, a disposição normativa em questão deixou à discricionariedade (e não ao arbítrio) da ANS a regulamentação dos procedimentos afeitos à transplantes, podendo esta excepcionar aqueles que sejam inviáveis diante da realidade técnica, econômica e social. 7. Os critérios valorativos adotados pela ANS para excluir da cobertura básica mínima dos planos de saúde transplante de coração e de fígado fundaram-se em razões técnicas e razoáveis, não se podendo catalogar a Resolução no 167/07 como arbítrio científico, notadamente porque também geraria um excessivo ônus direto às empresas privadas que exploram atividade econômica no ramo da saúde, causando, conseqüentemente repercussão para os assistidos e para toda a coletividade em geral. 8. A regulamentação em questão não viola o princípio constitucional da dignidade da pessoa humana, e nem dispositivos legais do CDC, tendo em vista que se pauta na razoabilidade. 9. Apelações providas". (TRF 5a Região - $2^{\mathrm{a}}$ Turma, Apelação Cível $\mathrm{n}^{\mathrm{o}}$ 465575/PE (2008.83.00.008368-8), Rel. Des. Manuel Maia, j. 17.08.2010). 
nada tem de deferência ao entendimento da agência, uma vez que a deferência implica na análise dos elementos do ato regulatório e sua confirmação, caso se mostrem minimamente razoáveis.

Em outras, palavras, deferência significa o respeito ao quanto decidido, por entender o órgão judicial que a decisão é juridicamente correta, não a não análise da questão sob o argumento da tecnicidade ou da complexidade do setor regulado. Este último comportamento, com o devido respeito, implica na criação de um ramo estatal sem controle, o que não é admissível no Estado de Direito.

\section{III.E. - Um Fundamental Parâmetro a ser Observado pelo Judiciário: o Consequencialismo}

Até o presente ponto, a exposição deste capítulo teve como preocupação analisar a primeira questão feita no item III.A, ou seja, analisar qual a profundidade do controle judicial dos atos normativos das agências reguladoras.

O presente tópico possui como finalidade analisar a segunda questão colocada naquele item, qual seja, se a visão do controle da Administração calcada apenas na relação binária ilegalidade $=$ nulidade é suficiente para a atuação judicial frente aos atos normativos regulatórios.

Em nosso sentir, e isto será explorado neste tópico, a complexidade regulatória impõe ao órgão de controle ${ }^{431}$, no caso do presente trabalho o Judiciário, o dever de ponderar prospectivamente as consequências da sua atuação, com a finalidade de evitar que o controle se torne em mecanismo puro e simples de freio da atividade administrativa e que traga consequências mais gravosas aos cidadãos do que o ato ilegal já praticado.

\footnotetext{
${ }^{431}$ Falamos em órgão de controle, pois a análise consequencialista, em nosso entendimento, deve ser adotada por todos os órgãos de controle, tanto internos, quanto externos à Administração, tal como o Tribunal de Contas.
} 


\section{III.E.1 - O Consequencialismo: Noção Geral e sua Presença no Direito Brasileiro}

A análise consequencialista do direito tem por objetivo verificar as consequências econômicas e sociais das decisões jurídicas, o que implica em uma importante alteração do referencial que sempre embasou a atuação dos aplicadores do Direito.

Com efeito, conforme cediço, sempre se pensou a aplicação do Direito com base no simples silogismo: fatos-norma-consequência prevista na norma, de modo que a função do aplicador estava em identificar os fatos no mundo concreto, extrair do texto legal o seu conteúdo normativo e aplicar aos envolvidos na situação fática as consequências previstas no texto legal.

Por mais que nos últimos anos tenha surgido a doutrina da normatividade dos princípios jurídicos, o esquema geral de aplicação do Direito não foi alterado, ganhando apenas mais elementos a serem considerados na extração do conteúdo normativo do texto legal, que agora passa a ter o influxo dos princípios incidentes sobre determinado caso.

Se tal esquema de aplicação normativa baseado no Direito puro, ou seja, sem qualquer interferência de outras áreas do conhecimento, foi, e ainda é, útil para a regulação de conflitos intersubjetivos de índole retributiva ${ }^{432}$, ele mostra problemas no que se refere aos conflitos coletivos de natureza distributiva, tendo em vista que não se presta a analisar as consequências sociais e econômicas das decisões jurídicas.

Com efeito, o modelo de aplicação tradicional do Direito implica em que o aplicador tenha os olhos voltados para trás, para o que ocorreu, com a finalidade de impor as consequências jurídicas normativamente previstas à época dos fatos, sem a preocupação com as consequências coletivas de tal aplicação.

\footnotetext{
${ }^{432}$ Tal esquema prevalece no âmbito dos conflitos privados, tais como nas locações, relações de direito de família, relações comerciais, direitos dos contratos etc., o que não impede que em tais relações jurídicas haja uma análise das consequências coletivas das ações individuais. Nesse sentido, cf. RICARDO LUIS LORENZETTI, Teoria da decisão judicial: fundamento de direito, 2010, p. 305 e segs.
} 
E tal ausência de análise das consequências dos atos estatais implica em importante obstáculo para a eficiência do Estado enquanto instituição voltada à consecução de finalidades coletivas, tendo em vista que não se deve analisar apenas o que se faz, as razões pelas quais se faz, mas, também, as consequências do que se faz ${ }^{433}$.

Nesse sentido, então, o ferramental jurídico puro, baseado apenas na relação fato-norma não se mostra totalmente adequado para a solução dos conflitos que envolvem direitos coletivos e de decisões que têm o condão de causar impactos sobre os sistemas regulados e, por consequência, sobre os direitos dos agentes de tais sistemas, gerando um desequilíbrio sistêmico.

E o Direito, a despeito de toda a evolução doutrinária pela qual passou nos últimos séculos, não se mostrou capaz de servir como um ferramental que tenha por finalidade a aferição das consequências da aplicação do direito, tendo em vista que é construído sobre um código binário conformidade com o direito/desconformidade com o direito.

Assim, é necessário buscar um novo ferramental que venha a permitir que os operadores jurídicos analisem as consequências dos atos jurídicos, o que envolve tanto a Administração Pública quanto os órgãos de controle. A esse respeito aponta PHILLIP GIL FRANÇA:

\begin{abstract}
"Saber o que fazer, quando fazer, como fazer e, fundamentalmente, quais as consequências do que é feito é importantíssimo para a se verificar uma boa gestão pública. Obviamente, o administrador público precisa ter em mente quais serão os reflexos de sua responsável atuação para que sua atividade efetivamente alcance a realização do desenvolvimento esperado.

Não apenas no momento de preparação e de realização do ato administrativo tal preocupação precisa ser priorizada no bom agir administrativo, mas, de sobremaneira, no momento do controle da gestão pública. Verificar como a atuação administrativa vai influir na vida dos administrados e de que forma, ao longo do tempo, tal atuação administrativa continuará trazendo benefícios à população é dever tanto do responsável pela boa gestão pública, como dos respectivos órgãos controladores (inclusive, o Judiciário) ${ }^{\text {"334. }}$
\end{abstract}

A questão do consequencialismo liga-se a um Direito responsivo, reflexivo, preocupado com a efetividade das finalidades públicas que pretende instituir, sendo os

\footnotetext{
${ }^{433}$ PHILliP GIL FRANÇA, Ato administrativo e interesse público: gestão pública, controle judicial e consequencialismo administrativo, 2013, p. 122.

${ }^{434}$ Ato administrativo..., cit., p. 96.
} 
institutos jurídicos entendidos como meios para o alcance de tais finalidades, não mais como finalidades em si, com a desconsideração do contexto social e econômico.

Não nos aprofundaremos na questão teórica subjacente a tal forma jurídica, o que nos remeteria à profunda e densa teoria dos sistemas e da autopoiese jurídica ${ }^{435}$, no entanto, não podemos deixar de apontar que tal análise implica no reconhecimento de que o Direito moderno, constituído apenas na aplicação das normas enquanto tal não é mais suficiente para manter os padrões de legitimidade da ação do Estado.

Isto não significa que o Direito deva se curvar à economia ou a outras ciências, mas, apenas, que sua construção teórica leva em consideração as questões sociais e econômicas como meio de criação do Direito. Assim, dentro de um sistema social, o subsistema jurídico possui elementos (antenas, como nos diz GUNTHER TEUBNER ${ }^{436}$ ) para captar as interferências externas e transformá-las em normas jurídicas, que serão utilizadas como posteriores normas de decisão.

É deste embate entre o sistema jurídico e os demais sistemas sociais - que, num Estado de Direito devem se manifestar legitimamente por meio do Direito -, que surge a questão da finalidade das normas e das consequências de suas aplicações. Nas palavras AleXANDRE SANTOS DE ARAGÃO, "O Direito não pode ignorar a realidade social sobre a qual incide. As regras jurídicas devem ter a validade de sua aplicação aferida do ponto de vista da sua eficácia, instrumental à realização prática dos seus objetivos públicos, não apenas do ponto de vista de sua conformidade em tese com os atos normativos hierarquicamente superiores" ${ }^{437}$.

Nesse passo, PhilipPe Nonet e PhILIP SElzNICK ${ }^{438}$ apontam que a responsividade do direito sugere a existência de uma capacidade para manter a sua integridade, ao mesmo tempo em que possui elementos que permitam a captação dos elementos extrínsecos necessários ao seu desenvolvimento, de modo que percebe as forças sociais como fonte de autocorreção e evolução.

\footnotetext{
${ }^{435}$ Para tanto, cf. Celso Fernandes Campilongo, Política..., cit., e José Eduardo Faria, O direito na economia globalizada, cit.

${ }^{436}$ Le droit: un systhéme autopoietique, 1993, p. 112.

${ }^{437}$ Ensaio de uma visão autopoiética do direito administrativo, Revista de Direito Público da Economia, $\mathrm{n}^{\mathrm{o}}$ 04, out/dez 2003, p. 10.

${ }^{438}$ Law and society in transition: toward responsive law, $2^{\mathrm{a}}$ ed., $2^{\mathrm{a}}$ reimp., 2005, p. 77.
} 
Com efeito, tal forma jurídica inovada implica também em novos métodos de análise jurídica e de controle das instituições. Tendo por base que tal Direito possui também a preocupação de se legitimar perante as demais forças da sociedade, a sua forma de aplicação deve levar em consideração as consequências da decisão, sem se contentar com a pura e simples subsunção fato-norma-consequencia normativamente prevista.

Surge, então, a seguinte pergunta: a despeito do aspecto teórico, haveria no direito brasileiro alguma manifestação de julgamento que leve em consideração, além dos aspectos jurídicos, as consequências da decisão judicial?

A resposta é afirmativa e encontra-se no próprio direito público nacional, no instituto da suspensão de liminar, de segurança e de tutela antecipada, previstos há muito no direito brasileiro ${ }^{439}$. Tal instituto está previsto em diversas leis processuais civis, quais sejam, a Lei $\mathrm{n}^{\mathrm{o}} 12.016 / 09^{440}$ (mandado de segurança), a Lei $\mathrm{n}^{\circ} 7.347 / 85^{441}$ (ação civil pública), e Lei no $8.437 / 92^{442}$, bem como estendida para tutela antecipada por

${ }^{439}$ O instituto da suspensão de segurança já era previsto no artigo 13 da Lei no 191/1936 (JOSÉ MiGUEL GARCIA MEDINA e FÁBIO CALDAS DE ARAÚJO, Mandado de segurança individual e coletivo: comentário à Lei 12.016, de 7 de agosto de 2009, 2009, p. 175).

440 “Art. 15. Quando, a requerimento de pessoa jurídica de direito público interessada ou do Ministério Público e para evitar grave lesão à ordem, à saúde, à segurança e à economia públicas, o presidente do tribunal ao qual couber o conhecimento do respectivo recurso suspender, em decisão fundamentada, a execução da liminar e da sentença, dessa decisão caberá agravo, sem efeito suspensivo, no prazo de 5 (cinco) dias, que será levado a julgamento na sessão seguinte à sua interposição.

$\S 1^{\circ}$ Indeferido o pedido de suspensão ou provido o agravo a que se refere o caput deste artigo, caberá novo pedido de suspensão ao presidente do tribunal competente para conhecer de eventual recurso especial ou extraordinário.

$\S 2^{\underline{o}}$ É cabível também o pedido de suspensão a que se refere o $\S 1^{\circ}$ deste artigo, quando negado provimento a agravo de instrumento interposto contra a liminar a que se refere este artigo.

$\S 3^{\mathrm{o}}$ A interposição de agravo de instrumento contra liminar concedida nas ações movidas contra o poder público e seus agentes não prejudica nem condiciona o julgamento do pedido de suspensão a que se refere este artigo.

$\S 4^{\mathrm{O}}$ O presidente do tribunal poderá conferir ao pedido efeito suspensivo liminar se constatar, em juízo prévio, a plausibilidade do direito invocado e a urgência na concessão da medida.

$\S 5^{\mathrm{o}}$ As liminares cujo objeto seja idêntico poderão ser suspensas em uma única decisão, podendo o presidente do tribunal estender os efeitos da suspensão a liminares supervenientes, mediante simples aditamento do pedido original".

${ }^{441}$ É o quanto determina o artigo $12, \S 1^{\circ}$ : “§ $1^{\circ}$ A requerimento de pessoa jurídica de direito público interessada, e para evitar grave lesão à ordem, à saúde, à segurança e à economia pública, poderá o Presidente do Tribunal a que competir o conhecimento do respectivo recurso suspender a execução da liminar, em decisão fundamentada, da qual caberá agravo para uma das turmas julgadoras, no prazo de 5 (cinco) dias a partir da publicação do ato".

${ }^{442}$ Consoante o artigo $4^{\circ}$, caput e $\$ 1^{\circ}$ :

"Art. $4^{\circ}$ Compete ao presidente do tribunal, ao qual couber o conhecimento do respectivo recurso, suspender, em despacho fundamentado, a execução da liminar nas ações movidas contra o Poder Público 
meio do art. $1^{\text {o }}$, da Lei $\mathrm{n}^{\circ}$ 9.494/97, e possui por finalidade evitar que a liminar ou a sentença cujo cumprimento possa implicar em grave lesão à ordem, à saúde, à segurança e à economia públicas, sendo que o Presidente do Tribunal competente para conhecer do recurso (contra a sentença ou liminar) poderá suspender a execução ou o cumprimento da medida judicial. Nas palavras de LEONARdo CARNEIRO DA CUNHA, "Objetiva-se com o pedido de suspensão, sobrestar o cumprimento da liminar ou da ordem concedida, subtraindo seus efeitos, com o que se desobriga a Fazenda Pública do cumprimento da medida" ${ }^{443}$.

Sem adentrar em celeumas processuais, parece-nos que tal instituto não pode ser considerado como recurso ou sucedâneo recursal, tendo em vista que o pedido de suspensão é destinado, tão somente, "a retirar da decisão a sua executoriedade; serve, simplesmente, para suspender a decisão, mantendo-a, em sua existência, incólume" ${ }^{444}$, de tal forma que não se aplica à decisão do Presidente que a conceder o efeito substitutivo do recurso, previsto no artigo 512 do Código de Processo Civil ${ }^{445}$.

Assim, por meio de tal medida não se analisa a correção ou incorreção jurídica da decisão judicial que concedeu a liminar ou a segurança ${ }^{446}$, mas sim os efeitos da execução de tal decisão à ordem, à saúde, à segurança e à economia popular, o que implica, em nosso sentir, em um juízo consequencialista por parte do Presidente do Tribunal (= magistrado), bem como a plausibilidade do direito invocado por aquele que suscita a medida suspensiva ${ }^{447}$. Ou seja, há uma análise jurídica superficial e com foco nas consequências da decisão judicial.

ou seus agentes, a requerimento do Ministério Público ou da pessoa jurídica de direito público interessada, em caso de manifesto interesse público ou de flagrante ilegitimidade, e para evitar grave lesão à ordem, à saúde, à segurança e à economia públicas.

$\S 1^{\circ}$ Aplica-se o disposto neste artigo à sentença proferida em processo de ação cautelar inominada, no processo de ação popular e na ação civil pública, enquanto não transitada em julgado”.

443 A Fazenda Pública em juízo, 2009, p. 569.

${ }^{444}$ Idem, p. 573.

${ }^{445}$ Idem, ibidem. Determina o referido dispositivo: "O julgamento proferido pelo tribunal substituirá a sentença ou a decisão recorrida no que tiver sido objeto de recurso".

${ }^{446}$ A incolumidade da decisão que concedeu a liminar ou a segurança é comprovada pela Súmula ${ }^{\circ} 626$ do STF, que determina: “A suspensão da liminar em mandado de segurança, salvo determinação em contrário da decisão que a deferir, vigorará até o trânsito em julgado da decisão definitiva de concessão da segurança ou, havendo recurso, até a sua manutenção pelo Supremo Tribunal Federal, desde que o objeto da liminar deferida coincida, total ou parcialmente, com o da impetração".

${ }^{447}$ Cf. STF, AgRg na SS 846/DF e STJ, SLS 1818. 
Em outras palavras, tal instituto consiste em demonstração da existência no direito brasileiro de um instrumento muito utilizado e que tem por finalidade precípua a análise das consequências de uma decisão judicial para a coletividade, sem que se adentre no mérito da causa em debate ou na correção jurídica da decisão atacada.

\section{III.E.2 - A Importância do Consequencialismo na Atividade de Controle da}

\section{Administração Pública}

Visto, em breves palavras, o significado do direito responsivo, devemos analisar qual a importância do consequencialismo para o controle judicial da regulação estatal.

A evolução legislativa das últimas décadas elevou o Judiciário a um novo patamar no que se refere à consecução de finalidades públicas. De órgão apenas de controle do abuso de poder, com a finalidade precípua de anular o ato ilegal, exatamente naquele binômio de que falamos acima (autoridade $\mathrm{x}$ liberdade), passou-se a ter um órgão que foi autorizado a disputar com a Administração Pública a realização do interesse público.

Tal novo papel do judiciário ganhou fôlego, conforme anota CARLOS ARI SUNDFELD $^{448}$, com a edição da Lei n ${ }^{\circ} 7.347 / 85$ (ação civil pública), que elenca no artigo $1^{\text {o449 }}$ uma série de interesses de índole difusa a serem tutelados e estipula uma ação a ser ajuizada pelo Ministério Público ou por outros co-legitimados, com a finalidade de tutelar tais interesses.

\footnotetext{
448 Administração e justiça: um novo equilíbrio?, in Direito Administrativo para Céticos, $2^{a}$ ed., 2014, p. 332 e segs.

${ }^{449}$ É a redação de tal dispositivo, com as alterações legislativas até dezembro de 2014:

“Art. $1^{\circ}$ Regem-se pelas disposições desta Lei, sem prejuízo da ação popular, as ações de responsabilidade por danos morais e patrimoniais causados: (Redação dada pela Lei n 12.529 , de 2011). 1 - ao meio-ambiente;

11 - ao consumidor;

III - a bens e direitos de valor artístico, estético, histórico, turístico e paisagístico;

IV - a qualquer outro interesse difuso ou coletivo. (Incluído pela Lei no 8.078 de 1990)

V - por infração da ordem econômica; (Redação dada pela Lei n ${ }^{\circ} 12.529$, de 2011).

VI - à ordem urbanística. (Incluído pela Medida provisória no 2.180-35, de 2001)

VII - à honra e à dignidade de grupos raciais, étnicos ou religiosos. (Incluído pela Lei no 12.966 , de 2014) VIII - ao patrimônio público e social. (Incluído pela Lei no 13.004 , de 2014)”.
} 
Da leitura dos interesses tutelados por referida Lei, o que se percebe é que, na realidade, a despeito de chamados de interesses difusos ou coletivos ${ }^{450}$, nada mais são do que interesses públicos na acepção aqui defendida, ou seja, (i) de inexistência de um único interesse público a ser perseguido e tutelado pelo Estado, e (ii) da existência de diversos interesses públicos, tutelados pelo ordenamento e que são objeto de ponderação e de consideração no caso concreto, definindo-se qual será o interesse público primário e como se dará a efetivação, ou não, dos demais interesses, públicos $a$ priori, mas secundários para o caso concreto.

Assim, a propositura da ação judicial permite ao "Judiciário disputar de verdade com a Administração o papel que ela desempenhava no cuidado com o interesse público" ${ }^{451}$, o que mudou a forma de gestão pública, com a entrada de mais um ator, de modo que "O foro judicial se politizou, a Administração e o Legislativo perderam claramente o monopólio do interesse público. Mais um capítulo da instigante judicialização da vida"452.

No entanto, a despeito de tais mudanças importantes na legislação e no papel do Judiciário no âmbito dos conflitos distributivos, a forma de controle da Administração pouco ou quase nada mudou nos últimos anos, sendo exercido um controle nos mesmos moldes do controle realizado há décadas e sob o pálio da bipolaridade autoridade versus liberdade, ou seja, sob a lógica do direito subjetivo tido como violado pela ação administrativa ${ }^{453}$.

\footnotetext{
${ }^{450}$ Em nosso sentir, a denominação interesses difusos e coletivos se deve a duas concepçães ainda muito enraizadas em nosso direito administrativo e que era praticamente unânime nas décadas de 80 e 90 do século passado, quando surgiram a Lei no 7.347/85 e o Código de Defesa do Consumidor: (i) de um lado, a concepção de que o interesse público é identificado com o interesse tutelado apenas pelo Estado, sem que os particulares possam fazê-lo; e (ii) de outro, a concepção de que o interesse público não pode ser objeto de análise ou controle pelo Poder Judiciário, sob pena de ofensa à separação de poderes, o que demanda uma exclusividade administrativa na sua consideração e perseguição.

${ }^{451}$ CARLOS ARI SUNDFELD, Administração e justiça..., cit., p. 333.

${ }^{452}$ Idem, p. 334.

${ }^{453}$ A esse respeito, importantes as considerações do estudo coordenado por JULIANO SOUZA DE Albuquerque Maranhão, Paulo Furquim de AZEVedo e Tércio Sampaio Ferraz Júnior: "Diante de uma forte tendência ainda arraigada na cultura jurídica do País, o que se observa é o tratamento entre a agência reguladora e o agente regulado nos quadros tradicionais de um Direito Administrativo que, ao lidar com a intervenção do Estado no domínio privado, ora oscila entre o uso instrumental de atos vinculados e discricionariedade técnica, ora dá preferência a soluções privatistas mesmo se tratando de bens e ativos consistentes em infraestrutura essencial, de interesse coletivo, como se fossem ativos privados, em detrimento de julgamento capaz de sopesar as questões à luz de uma ordem jurídica que lida com políticas regulatórias setoriais, cujas diretrizes estão em resoluções setorialmente técnicas, mas se encontram em leis e decretos, estando aí a necessidade de conciliar a tradicional supremacia dos interesses públicos do Estado sobre interesses privados com os interesses difusos da coletividade. (...) as
} 
E, ao que nos parece, é necessária uma mudança de visão do controle judicial e dos seus agentes. Com efeito, por mais que em nosso entendimento a atuação judicial na análise das questões discricionárias, o que inclui as matérias de políticas públicas e regulatórias não permita ao Judiciário se substituir à Administração, não podemos negar que, de fato, a inclusão do Judiciário em tal circuito implica (i) na mudança na visão comum de que juízes e promotores são apenas controladores - no sentido de "anuladores" da ação administrativa - para a visão de que a própria legislação dotou tais agentes de poderes para "disputarem com os agentes administradores a realização do interesse público" ${ }^{454}$; e (ii) na alteração de postura que os magistrados devem ter diante de conflitos de tal natureza.

A atribuição de novos poderes a tais atores judiciais implica na necessidade de uma mudança na forma de se conceber o controle da atividade administrativa, tendo em vista que todos aqueles que sejam partícipes na consecução de finalidades de interesse público devem agir de modo eficiente e analisar as consequências para a coletividade das decisões tomadas.

Ainda nas palavras de CARLOS ARI SUNDFELD, "Do mesmo modo que o direito administrativo histórico procurou coibir a ineficiência e o arbítrio administrativos, o novo direito público teria de ser capaz de regular consistentemente a construção do interesse público nos processos judiciais, impedindo o arbítrio e a ineficiência dos órgãos e agentes judiciais" ${ }^{\prime 455}$.

Mostra-se necessário, então, alterar a forma como se pensa o controle, com a finalidade de que ele seja instrumento de consecução de finalidades públicas outras que não apenas o abuso de poder e a corrupção.

ações levadas ao Judiciário não tomam efetivamente contato com a finalidade e os fundamentos das políticas tecnicamente regulatórias. Em vez disso, o Judiciário observa as consequências de uma intervenção só na esfera privada do direito subjetivo em questão no caso concreto, ignorando as consequências de uma decisão judicial para a política regulatória e para a sinalização proporcionada para o comportamento do mercado e dos agentes daquele setor. Modificar esse comportamento, obviamente, não significa abandonar o instrumental conceitual tradicional, nem agir fora dos contornos da lei, mas entender que as atividades privadas de interesse público ou de interesses difusos afetam os consumidores em um mercado livre e por isso exige-se que este seja regulado por técnicas restritivas e diretrizes econômicas impositivas". (Direito regulatório..., cit., p. 241-242).

${ }^{454}$ Idem, p. 332.

455 Idem, p. 339. 
Conforme bem aponta Floriano de Azevedo Marques Neto ${ }^{456}$, o controle da Administração é visto na atualidade sob a perspectiva da "autonomização", ou seja, como um fim em si mesmo, o que tem levado, entre outros, aos seguintes problemas: (i) déficit de responsividade, o que implica na visão do controle mais como meio de coibir abusos, ainda que isto implique na inoperância da Administração, do que como forma de analisar os impactos que a atividade administrativa e seus efeitos; (ii) captura das políticas públicas pelo controlador, com a apropriação pelo controlador da pauta de políticas públicas; e (iii) o deslocamento da discricionariedade da Administração para o controlador, que, agindo ex ante, acaba por fazer a escolha do que entenda ser a melhor opção para o administrador, o que reduz a margem de atuação deste.

Tal forma de controle, baseada na noção de controle do poder, que tem por finalidade tutelar os indivíduos contra o arbítrio estatal, não parece ser a melhor no que se refere ao controle das políticas públicas e regulatórias, pois não é um controle exercido com a preocupação das consequências da atividade controladora, mas apenas voltado à coibição do abuso de poder.

Assim, sob o argumento de tutelar o interesse público, sob esta perspectiva entendido como sinônimo de uma administração proba e que não abuse do poder, a atividade judicial acaba, muitas vezes, inviabilizando a própria atividade administrativa, causando danos a outros interesses públicos que não tenham sido objeto da lide e, portanto, não vislumbrados pelo magistrado.

É dizer, com a finalidade de coibir uma ilegalidade, o Judiciário acaba afrontando outros tantos direitos que estavam presentes no caso em tela, a despeito de não vislumbrados, o que implica em um efeito em cadeia, que implique na multiplicação de ações e recursos judiciais.

Diante desta realidade complexa e ao mesmo tempo contraditória, é necessário que as decisões judiciais de controle da atividade regulatória possuam uma análise

\footnotetext{
${ }^{456}$ Os grandes desafios..., cit., p. 228-231.
} 
prospectiva e consequencialista, não mais se limitando ao silogismo fato-normaconsequencia normativa.

Na linha do quanto aponta RICARDO LuIS LORENZETTI, “O julgador que não mede os efeitos da decisão quanto ao caso concreto, ou também as consequências posteriores ou o impacto do julgado em outros pronunciamentos, consuma uma interpretação desqualificável por imprevidente" ${ }^{\text {457. }}$.

Na mesma linha, pontifica Diogo DE Figueiredo Moreira Neto:

“O aplicador da lei, seja o administrador, seja o juiz, não pode desligar-se do resultado de sua ação e considerar cumprido seu dever com a mera e simples aplicação racional da norma aos fatos. Sua tarefa deve ir além: é criativa por natureza, pois que com ela deve integrar a ordem jurídica.

A ordem jurídica, com efeito, contém o ordenamento positivo, mas nele não se esgota; a par de seus preceitos, gerais e abstratos, integram-na também os atos do Poder Público que a aplicam concretamente. Os atos administrativos e judiciários que executam o direito, dito de outra forma, conformam a ordem jurídica.

São, efetivamente, esses atos de aplicação que irão, em última análise concretizar o direito, dar-lhe vida, realizar efetivamente os interesses por ele destacados e protegidos. A aplicação do direito não é um ato puramente técnico, neutro ou mecânico; não se esgota no racional nem prescinde de valorações e estimativas. A realização da ordem jurídica se faz por atos humanos, interessados, razoavelmente aptos a impor os valores e os interesses estabelecidos pelo legislador" ${ }^{458}$.

Diante disto, surge a questão: como operacionalizar um controle da Administração que ao mesmo tempo iniba e coíba o desvio de finalidade e possua uma visão prospectiva?

A questão, em nosso sentir, está intimamente ligada à preservação das competências administrativas para a atuação nos setores que institucionalmente ela dever agir. É dizer, o controle não deve ser exercido apenas pela vertente de tolher a atividade administrativa, mas sim com a finalidade de demonstrar o caminho errado, com o propósito de aperfeiçoá-la.

Com efeito, como bem apontam PhilipPe Nonet e Philip SElzNicK ${ }^{459}$, a melhor forma de se evitar a arbitrariedade dentro da lógica do direito responsivo é

\footnotetext{
${ }^{457}$ Teoria da decisão..., cit., p. 321.

${ }^{458}$ Legitimidade..., cit., p. 56.

${ }^{459}$ Law and society in transition: toward responsive law, $2^{\mathrm{a}}$ ed., $2^{\mathrm{a}}$ reimp., 2005, p. 110 e 106-107.
} 
aumentar a competência das instituições, não diminuí-las, sendo certo que uma forma de melhorar a legitimidade do Direito seria através do diagnóstico institucional dos problemas e redesenho do arranjo institucional.

Ou seja, o controle deve servir como meio de aprimoramento da atividade administrativa, o que não significa que o controlador deva fechar os olhos à ilegalidade ou ao abuso de poder. O que o controle deve fazer é servir de mecanismo para a consecução de finalidades públicas, sempre com vistas a, ao mesmo tempo em que reprime os abusos, permitir que as finalidades públicas sejam alcançadas.

A esse respeito, importantes as considerações de Floriano DE AzEVEdo MARQues Neto, que, a despeito de longas, bem deixam expressas as novas funções do controle da Administração:

\begin{abstract}
"Uma das vertentes que deve sempre ser considerada quando tratamos do tema do controle é a que diz com suas consequências. O controle não é um fim em si mesmo. Ele é um instrumento para o aperfeiçoamento da Administração e para a busca de eficiência e efetividade. A presunção de que o controle valha por si só, como se a mera existência de estruturas de controle seja suficiente para a boa administração trai uma visão formalista do controle. A Administração Pública somente é eficiente se, além de não desperdiçar recursos públicos (evitando o desvio ou o desperdício) ela logra atender às necessidades coletivas que correspondem à finalidade do agir administrativo. Qualquer controle que, sob o pálio de coibir o desvio e o desperdício impede a consecução de uma ação administrativa acaba por produzir um efeito contrário àquele que justifica a existência do controle. Para impedir que a Administração gaste mais do que o devido numa obra ou numa compra, não se deve predicar que ela seja impedida de executar uma obra ou adquirir um insumo. O entrave da Administração pelo controle acaba por causar malefício comparável àquele gerado pelas condutas ímprobas. Uma Administração pia, proba e imprógida não é necessariamente uma Boa Administração. Será de conciliar lisura e economicidade com eficiência e efetividade. Do mesmo modo, um sistema de controle que só pune, invalida e impede não será um controle conforme aos cânones do Estado Democrático de Direito. Será de conseguir combinar rigor no combate aos despautérios com a verificação ponderada das consequências das medidas de coibição a seu alcance. Ademais, será um bom sistema de controle se aferir também os resultados das políticas públicas e das ações administrativas, verificando o quanto elas estão a reverter para a sociedade ${ }^{360}$.
\end{abstract}

Aplicado ao âmbito da regulação econômica, o controle pela matriz responsiva implica na necessidade de que o Judiciário analise quais serão as consequências da medida adotada (a concessão de uma liminar, a decretação da nulidade do ato normativo etc.) perante o sistema regulado, o que implica em um juízo prospectivo, que tenha em

${ }^{460}$ Os grandes desafios..., cit., p. 207. 
vista não apenas a norma eventualmente afrontada pela Administração, mas também os impactos da medida judicial no sistema regulado.

\title{
Como bem ensina Marcos PaUlo Veríssimo
}

\begin{abstract}
"Nesse passo, não basta a menção a fatos provados e ao direito legislado, porque esses elementos, por sis sós, pouco dizem à ação regulatória. Nessa área, a decisão judicial precisa explicitar as razões sociais, econômicas e políticas que a fundamentam. Cuidando-se de decisões que possuem muitas vezes conteúdo econômico marcante, é importante que a decisão considere sempre e de forma declarada, a medida em que uma determinada distribuição de custos e benefícios é, por ela, empreendida entre a sociedade, determinados grupos de interesse e determinados agentes em especial, inclusive para fins de controle" ${ }^{461}$.
\end{abstract}

Tal aferição dos impactos da medida judicial no sistema regulado não é feita com a finalidade de "tornar o controle mais lasso, mas para modular as medidas corretivas ou acautelatórias no sentido de que a elas tenham o menor impacto para o interesse público mais denso envolvido no caso" ${ }^{\text {462 }}$. Assim, por exemplo, caso seja questionada em juízo norma que venha a fixar valor das tarifas, deve o Judiciário analisar qual será o impacto no setor regulado, antes de decretar a nulidade do ato normativo.

Aqui, parece-nos de extrema valia a utilização pelo magistrado da modulação dos efeitos da decisão tomada, com a finalidade de temperar os efeitos que a invalidação total ou parcial do ato normativo regulatório terá no sistema regulado. Não cabem mais afirmações como aquelas clássicas de que "Os efeitos da anulação dos atos administrativos retroagem às suas origens, invalidando as consequiências passadas, presentes e futuras do ato anulado. E assim é porque o ato nulo (ou o inexistente) não gera direitos ou obrigações para as partes; não cria situações jurídicas definitivas; não admite convalidação" ${ }^{463}$.

Parece-nos que o controle judicial que a sociedade necessita hoje, para a concretização dos direitos inerentes aos setores regulados, o que implica estabilidade e segurança jurídica, é um controle que module os efeitos das decisões que invalidam atos

\footnotetext{
${ }^{461}$ Controle judicial da atividade normativa das agências de regulação brasileiras, in Alexandre Santos de Aragão, $\mathbf{O}$ poder normativo das agência reguladoras, $2^{\mathrm{a}}$ ed., 2011, p. 312.

${ }^{462}$ FLORIANO DE AZEVEDO MARQUES NETO, Os grandes desafios..., cit., p. 207.

${ }^{463}$ Hely LOPES MeIRELLES, Direito administrativo..., cit., p. 182.
} 
administrativos, com a finalidade de gerar o menor impacto sistêmico no setor regulado e o impacto menos abrupto possível.

Consoante as percucientes colocações de CARLOS ARI SUNDFELD, a respeito da intervenção judicial na regulação, que leva o Judiciário a assumir o ônus do regulador:

\begin{abstract}
"Elaborar e enunciar com clareza e precisão a regra que, a partir dos princípios, entendem dever ser utilizada em juízo para resolver os casos concretos do mesmo modo que o regulador faz regulamentos, com suas especificações, antes de sair tomando atitudes caso a caso. Estudar com profundidade a realidade em que vão mexer, entender as características e razões da regulação anterior, identificar as alternativas regulatórias existentes, antever os possíveis custos e os impactos, positivos e negativos, em todos os seus aspectos, da nova regulação judicial que se cogita instituir, comparar as características da regulação existente e da cogitada. Tudo isso tem de aparecer na motivação da decisão judicial"464.
\end{abstract}

Assim, ao decidir a respeito da invalidação de determinado ato regulatório, o Judiciário deve se perguntar se o sistema regulado atingirá melhor suas finalidades legalmente previstas sem o ato impugnado, ou seja, se a invalidação total e retroativa do ato regulatório é efetivamente necessária para a salvaguarda da legalidade e da finalidade do setor regulado.

Com efeito, ao controlar os atos regulatórios, o Judiciário deve se perguntar, por exemplo, (i) se a invalidação do ato normativo regulatório é o melhor meio de salvaguardar a legalidade e a finalidade do setor regulado sobre o qual se exerce o controle; (ii) se a invalidação deve ou não retroagir à época da edição do ato normativo; (iii) se é possível a permanência do ato regulatório no ordenamento até que outro seja expedido em substituição a ele; (iv) quais os efeitos concretos que a anulação total, parcial, retroativa ou não terá sobre o sistema regulado; (v) quais as razões que levaram a agência a adotar determinada política regulatória no sentido do ato normativo expedido.

Enfim, há uma miríade de questões a serem feitas com a finalidade de evitar que medidas judiciais calcadas apenas na relação legalidade/ilegalidade acabem por prejudicar a estabilidade e o desenvolvimento de um sistema regulado.

${ }^{464}$ Princípio é preguiça?, in Direito Administrativo para Céticos, $2^{\text {a }}$ ed., 2014, p. 228-229. 


\section{III.F - Conclusões Parciais}

De acordo com o quanto afirmado nas páginas acima, o que resta patente para nós é que o Judiciário possui a missão institucional de controlar a atuação normativa das agências reguladoras, com a finalidade de evitar a violação de direitos eventualmente praticada sob a roupagem da prática de atos discricionários e dotados de ampla margem de apreciação técnica.

A queda de alguns mitos que sempre povoaram os manuais de direito administrativo, notadamente a questão da insindicabilidade do mérito do ato administrativo abre uma importante possibilidade de controle da atividade regulatória, tendo em vista que esta é exercida com base em leis criadoras de subsistemas, que institucionalizam diversas finalidades a serem atingidas, sem colocar, no entanto, os meios de serem atingidas.

Nesse sentido, o Judiciário deve analisar tanto os aspectos da motivação, quanto os aspectos ligados aos princípios e postulados incidentes sobre os atos normativos, em vista das finalidades dos setores regulados e dos direitos dos diversos agentes do subsistema, para a aferição da juridicidade da atuação da agência.

No entanto, o controle judicial deve possuir a cautela de não se substituir à atividade reguladora, tendo em vista a competência institucional das agências para a regulação econômica. Assim, em sendo o ato regulador minimamente eficiência, razoável e proporcional, deve o Judiciário assumir uma postura de deferência com relação ao ato regulatório.

Ponto importante que deve nortear toda a atividade de controle da regulação se refere à análise das consequências a serem levadas em consideração pelo Judiciário, com a finalidade de mensurar os impactos da decisão judicial no subsistema regulado, notadamente em virtude da complexidade que é ínsita a eles. Assim, não basta mais a mera subsunção da norma ao caso, sendo também imposto ao magistrado a aferição e justificação da medida tomada, de acordo com os efeitos que ela gerará. 
Com efeito, tendo o Judiciário sido elevado à categoria de co-partícipe na análise das questões de políticas públicas e regulatórias, passa-se a exigir que ele atue não mais com a visão de olho no retrovisor, mas sim com uma visão prospectiva, que venha a sopesar causas e efeitos das decisões judiciais em lides coletivas e de serviços regulados, para que seja possível construir a finalidade legal posta no ordenamento para a efetivação dos direitos individuais. 


\section{CONCLUSÕES}

As alterações sociais, econômicas e políticas dos últimos implicaram em alterações tanto na função das leis, quanto nas próprias instituições de controle. Se o século XX viu a emergência do Executivo enquanto órgão central em torno do qual gravitavam os interesses e os grupos que pretendiam ver suas pretensões acolhidas pelo Estado, as últimas décadas do século XX e este nascer do século XXI viram outra realidade.

As crescentes demandas sociais dos diversos grupos antagônicos implicou no colapso do Estado Social calcado na intervenção direta do Estado na economia, o que levou à necessidade, nos países de direito administrativo de tradição europeiacontinental, de conceder a gestão e execução de serviços públicos e privados de interesse público à iniciativa.

Longe de representar uma retirada do Estado da intervenção econômica, apenas ocorreu a sua mudança de eixo, deixando de ser interventor na economia e passando a atuar sobre esta, na condição de regulador. Surgem as agências reguladoras como entes dotados de capacidade técnica absolutamente especializada, com a finalidade de permitir a instituição de setores regulados específicos e que possam atender aos anseios da sociedade pluricentrica.

No entanto, a existência dos ordenamentos setoriais das diversas agências não impediu a conflituosidade ou a conteve em seus seios. Pelo contrário, houve uma explosão da litigiosidade e da judicialização de questões de políticas regulatórias, o que nos leva à necessidade de repensar o papel do Judiciário enquanto órgão de controle.

Ao mesmo tempo em que foi alçado à categoria de policy maker, ainda que em nossa visão pelo aspecto negativo, ou seja, com a missão de emitir juízo apenas anulatório a respeito da política regulatória, o Judiciário acaba por assumir um papel cada vez mais central na sociedade contemporânea.

O problema que se coloca, então, é saber qual o novo papel do Judiciário em tal contexto, bem como qual a função do controle das agências reguladoras no atual 
contexto. O que pretendemos demonstrar foi que os novos conflitos de interesse que são decididos pelo Judiciário, não mais sob a perspectiva retributiva, mas sim distributiva, implicam na necessidade de uma mudança da forma como o controle é exercido, sendo necessária a superação do controle focado apenas na subsunção fato-normaconsequência normativa, mas também nas consequências do controle para o subsistema regulado.

Assim, propomos no presente trabalho que o controle judicial das agências reguladoras seja feito numa perspectiva consequencialista, pela qual o Judiciário analise não apenas a legalidade da atuação da agência, mas também os efeitos que a decisão por ele proferida terá no setor regulado, com vistas à maximização das finalidades sistêmicas e dos direitos individuais. 


\section{BIBLIOGRAFIA}

ALMEIDA, Fernando Dias Menezes de. Formação da teoria do direito administrativo no Brasil, Tese de Titularidade apresentada para a Faculdade de Direito da Universidade de São Paulo, São Paulo, 2013.

; ZAGO, Mariana Augusta dos Santos. Controle de políticas públicas pelo Poder Judiciário: breves ideias a partir do modo de estruturação da jurisdição, in SUNDFELD, Carlos Ari; ROSILHO, André. Direito da Regulação e Políticas Públicas, São Paulo: Malheiros, 2014, p. 91-103.

ÁLVAREZ-GEDIN, Sabino. Tratado general de derecho administrativo, Tomo I, Barcelona: Bosch, 1958.

AMARAL JÚNIOR, José Levi Mello do. Sobre a organização de poderes em Montesquieu: comentários ao capítulo VI do livro XI de o espírito das leis, Revista dos Tribunais, $n^{\circ} 868$, fev./2008, p. 53-68.

ARAGÃO, Alexandre Santos. Agências reguladoras e a evolução do direito administrativo econômico, $2^{\text {a }}$ Ed., Rio de Janeiro: Forense, 2003.

Curso de direito administrativo, Rio de Janeiro: Forense, 2012.

. Ensaio de uma visão autopoiética do direito administrativo, Revista de Direito Público da Economia, nº 04, out./dez. 2003, p. 9-15.

$\mathrm{O}$ poder normativo das agências reguladoras independentes e o estado democrático de direito, Revista de Informação Legislativa, $\mathrm{n}^{\circ}$ 148, out./dez. 2000, p. 275-299.

O princípio da eficiência, in MARRARA, Thiago (org.), Princípios de Direito Administrativo, São Paulo: Atlas, 2012, p. 375-381.

ARAÚJO, Florivaldo Dutra de. Motivação e controle do ato administrativo, Belo Horizonte: Del Rey, 1992.

ÁVILA, Humberto Bergmann. Teoria dos princípios: da definição à aplicação dos princípios jurídicos, 12a ed., São Paulo: Malheiros, 2011.

BADIN, Arthur Sanchez. Controle judicial das políticas públicas, São Paulo: Malheiros, 2013.

BANDEIRA DE MELlO, Celso Antônio. Curso de direito administrativo, $30^{\mathrm{a}}$ ed., São Paulo: Malheiros, 2013; e 22ª ed., São Paulo: Malheiros, 2007.

Discricionariedade e controle jurisdicional, $2^{\text {a }}$ ed., São Paulo:

Malheiros, 2007. 
Legalidade - discricionariedade - seus limites e controle, in

Grandes Temas de Direito Administrativo, São Paulo: Malheiros, 2009, p. 56-80.

O equilíbrio econômico nos contratos administrativos, in

Grandes Temas de Direito Administrativo, São Paulo: Malheiros, 2009, p. 199-218.

BANDEIRA DE MELLO, Oswaldo Aranha. Princípios gerais de direito administrativo, Vol. I, $2^{\text {a }}$ Ed., 1979.

BAQUER, Lorenzo Martín-Retorillo. La configuración jurídica de la administración pública y el concepto da "daseinsvorsorge", Revista de Administración Pública, n. 38, maio/agosto 1962, p. 35-65.

BARACHO, José Alfredo de Oliveira. O princípio da subsidiariedade: conceito e revolução, Revista de Direito Administrativo, nº 200, p. 21-54.

BARROSO, Luís Roberto. Curso de direito constitucional contemporâneo, São Paulo: Saraiva, 2009.

A constitucionalização do direito e suas repercussões no âmbito administrativo, in ARAGÃO, Alexandre Santos de; MARQUES NETO, Floriano de Azevedo. Direito Administrativo e Seus Novos Paradigmas, Belo Horizonte: Fórum, 2008, p. 31-63.

Apontamentos sobre as agências reguladoras, in MORAES, Alexandre de (org.), Agências Reguladoras, São Paulo: Atlas, 2002, p. 109-131.

Constituição, democracia e supremacia judicial: Direito e política no

Brasil contemporâneo, Revista Trimestral de Direito Público, $\mathrm{n}^{\circ}$ 55, julho 2011, disponível em http://www.bidforum.com.br/bid/PDI0006.aspx?pdiCntd=120637, acesso em 18.09.2014.

Princípio da legalidade - Delegações legislativas - Poder regulamentar - Repartição constitucional das competências legislativas. Boletim de Direito Administrativo, jan. 1997, p. 15-28.

BASSI, Franco. Note sulla discrezionalitá amministrativa, in AMOROSINO, Sandro (coord.). Le Transformazioni del Diritto Amministrativo: Scritti degli allievi per gli ottanta anni di Massimo Severo Giannini, Milano: Giuffrè, 1995.

BIELSA, Rafael. Derecho administrativo, vol. I, Buenos Aires: Libreria y Editorial "El Ateneo", 1947.

BINENBOJM, Gustavo. Uma teoria do direito administrativo, $2^{\mathrm{a}}$ ed., Rio de Janeiro: Renovar, 2008. 
BLACK, Julia. Procedimentalizando a regulação: parte II, in MATTOS, Paulo Todescan Lessa (coord.). Regulação Econômica e Democracia: O Debate Europeu, São Paulo: Singular, 2006, p. 167-203.

BOBBIO, Norberto. Liberalismo e democracia, Brasília: Brasiliense, 2000.

BONAVIDES, Paulo. Curso de direito constitucional, 23ª ed, São Paulo: Malheiros, 2008.

BONNARD, Roger. Le contrôle juridictionnel de l'administration, Paris: Dalloz, 2006 [reimpressão da edição de 1934].

BREYER, Stephen G.; STEWART, Richard B.; SUNSTEIN, Cass R.; VERMEULE, Adrian; HERZ, Michael E. Administrative law and regulatory policy: problems, texts and cases, $7^{\mathrm{a}}$ ed., New York: Wolters Kluwer, 2011.

BRUNA, Sérgio Varella. Agências reguladoras: poder normativo, consulta pública, revisão judicial, São Paulo: Revista dos Tribunais, 2003.

BUCCI, Maria Paula Dallari. Direito administrativo e políticas públicas, $1^{\text {a }}$ ed., $2^{\mathrm{a}}$ tir., São Paulo: Saraiva, 2006.

Políticas públicas e direito administrativo, Revista de Informação Legislativa, $n^{\circ} 133$, jan./mar. 1997, p.89-98.

BUENO, José Antônio Pimenta. Direito publico brazileiro e analyse da Constituição do Império, Rio de Janeiro: Typographia, Imp. e Const. de J. Villeneuve e Co., 1857.

BUENO, Vera Scarpinella. As lei de procedimento administrativo: uma leitura operacional do princípio constitucional da eficiência, in SUNDFELD, Carlos Ari; MUÑOZ, Guillermo Andrés (coords.). As Leis de Processo Administrativo (Lei Federal 9.784/99 e Lei Paulista 10.177/98), São Paulo: Malheiros, 2000, p. 342-363.

CAMPILONGO, Celso Fernandes. Política, sistema jurídico e decisão judicial, São Paulo: Saraiva, 2012.

CAMPOS, Francisco. Direito Administrativo, Rio de Janeiro: Imprensa Nacional, 1953. CANOTILHO, José Joaquim Gomes. Direito Constitucional e Teoria da Constituição, $7^{\mathrm{a}}$ Ed., Coimbra: Almedina, 2003.

CARVALHO FILHO, José dos Santos. A discricionariedade: análise de seu delineamento jurídico, in GARCIA, Emerson (coord.). Discricionariedade Administrativa, Rio de Janeiro: Lumen Juris, 2005, p. 3-42.

CASAGRANDE FILHO, Ary. Estado Regulador e Controle Judicial, São Paulo: Quartier Latin, 2007. 
CASSAGNE, Juan Carlos. El principio de legalidad y el control judicial de la dicricionalidad administrativa, Buenos Aires: Marcial Pons, 2009.

CASSESE, Sabino. A crise do Estado, São Paulo: Síntese, 2010.

CASTRO, Carlos Roberto Siqueira. O devido processo legal e os princípios da razoabilidade e da proporcionalidade, $4^{\mathrm{a}}$ ed., Rio de Janeiro: Forense, 2006.

CASTRO, Marcus Faro de. Formas jurídicas e mudança social: interações entre o direito, a filosofia, a política e a economia, São Paulo: Saraiva, 2012.

CAVALCANTI, Themístocles Bandão. A intervenção do Estado e as suas conseqüências na estrutura administrativa, in ; SILVA, Carlos Medeiros; e LEAL, Victor Nunes, Cinco Estudos, Rio de Janeiro: EDITORA, 1955, PÁGINAS Teoria dos atos administrativos, São Paulo: Revista dos Tribunais, 1973.

CHAPUS, René. Droit administratif général, tome 1, 15ª ed., Paris: Montchrestien, 2001.

CHEVALLIER, Jacques. La dimension symbolique du principe de légalité, Revue du Droit Public et de la Science Politique en France et à l'Étranger, no 6, 1990, p. 1651-1677.

L'état de droit, Revue du Droit Public et de la Science Politique en France et à l'Étranger, $n^{\circ} 2,1988$, p. 313-380.

O estado pós-moderno, trad. de Marçal Justen Filho, Belo Horizonte: Fórum, 2009.

CINTRA, Antônio Carlos de Araújo. Motivo e motivação do ato administrativo, São Paulo: Revista dos Tribunais, 1973.

CLÈVE, Clèmerson Merlin. Atividade legislativa do Poder Executivo, $3^{\text {a }}$ ed., São Paulo: Revista dos Tribunais, 2011.

COELHO, Paulo Magalhães da Costa. Controle jurisdicional da administração pública, São Paulo: Saraiva, 2001.

COMPARATO, Fábio Konder. Ensaio sobre o juízo de constitucionalidade das políticas públicas, in Revista de Informação Legislativa, n. 138, abr/jun. 1998, p. 39-48.

O indispensável direito econômico, Revista dos Tribunais, $n^{\circ}$ 923, set./2012, p. 37-52.

CORREIA, José Manuel Sérvulo. Legalidade e autonomia contratual nos contratos administrativos, Coimbra: Almedina, 1987. 
CRETELLA JÚNIOR, José. Anulação do ato administrativo por desvio de poder, Rio de Janeiro: Forense, 1978.

CRUZ, Alcides. Direito administrativo brasileiro, $2^{\text {a }}$ ed., Rio de Janeiro/São Paulo/Belo Horizonte: Francisco Alves e Cia., 1914.

CUÉLLAR, Leila. As Agências Reguladoras e seu poder normativo, São Paulo: Dialética, 2001.

CUNHA, Carlos Eduardo Bergamini. A subsidiariedade como vetor objetivo de restrição à intervenção regulatória do Estado na economia: definição e instrumentalização, Dissertação de Mestrado apresentada à Faculdade de Direito da Universidade de São Paulo, São Paulo, 2013.

CUNHA, Leonardo Carneiro da. A fazenda pública em juízo, $9^{a}$ ed., São Paulo: Dialética, 2011.

DALlARI, Adilson Abreu. Controle do desvio de poder, Revista Trimestral de Direito Público, n 46, 2004, p. 33-46.

DI PIETRO, Maria Sylvia Zanella. Direito administrativo, 24a ed., São Paulo: Atlas, 2012.

Discricionariedade administrativa na Constituição de 1988, $2^{\mathrm{a}}$ ed., São Paulo: Atlas, 2001.

Discricionariedade administrativa na Constituição de 1988, $3^{\text {a }}$ ed., São Paulo: Atlas, 2012.

. Parcerias na Administração Pública, 7ª ed., São Paulo: Atlas, 2009. . 500 anos de direito administrativo brasileiro, Revista Eletrônica de Direito do Estado, Salvador: Instituto de Direito Público da Bahia, $\mathrm{n}^{\circ}$ 5, janeiro/fevereiro/março de 2006, disponível em www.direitodoestado.com.br, acesso em 15.06.2011.

Da constitucionalização do direito administrativo: reflexos sobre o princípio da legalidade e a discricionariedade administrativa, in e RIBEIRO, Carlos Vinicius Alves, Supremacia do Interesse Público e outros Temas Relevantes do Direito Administrativo, São Paulo: Atlas, 2010, p. 175-196.

O direito administrativo brasileiro sob influência dos sistemas de base romanística e da Common Law, Revista Eletrônica de Direito Administrativo Econômico, $\quad \mathrm{n}^{\mathrm{o}} \quad 8, \quad$ nov./dez. 2006, disponível em http://www.direitodoestado.com/revista/REDAE-8-NOVEMBRO-2006-

MARIA\%20SYLVIA.pdf, acesso em 11.12.2010. 
DICEY, Albert Venn. Introduction to the study of the law of the constitution, $9^{\mathrm{a}}$ ed., Londres: Macmillan \& Co., 1956.

DROMI, Roberto. Sistema jurídico e valores administrativos, Porto Alegre: Sergio Antônio Fabris Editor, 2007.

DUGUIT, Léon. La separación de poderes y la asamblea nacional de 1789, Madri: Centro de Estudios Constitucionales, 1996.

EISENMANN, Charles. Cours de droit administratif, tomo II, Paris: LGDJ, 2014 [reimp. da edição de 1983].

ENTERRÍA, Eduardo García de. La lengua de los derechos. La formación del derecho publico europeo tras la revolución francesa, $3^{\text {a }}$ ed., Navarra: Civitas, 2009.

ENTERRÍA, Eduardo García de; FERNÁNDEZ, Tomás-Ramón. Curso de derecho administrativo, Vol. I, 13 ${ }^{\text {a }}$ ed., e Vol. II, 10 a ed., Madri: Civitas, 2006.

ESTORNINHO, Maria João. A fuga para o direito privado: contributo para o estudo da actividade de direito privado da Administração Pública, $2^{\text {a }}$ reimp., Coimbra: Almedina, 2009.

FAGUNDES, Miguel Seabra. O Controle dos atos administrativos pelo Poder Judiciário, $7^{\mathrm{a}}$ ed. (revista e atualizada por Gustavo Binenbojm), Rio de Janeiro: Forense, 2006.

FARIA, José Eduardo. O Direito na economia globalizada, $1^{a}$ Ed., $4^{\circ}$ tir., São Paulo: Malheiros, 2004.

FERNÁNDEZ, Tomás-Ramón. De la arbitrariedad de la administración, $5^{\text {a ed., }}$ Navarra: Civitas, 2008.

FERRAZ JÚNIOR, Tércio Sampaio. Agências reguladoras: legalidade e constitucionalidade, Revista Tributária e de Finanças Públicas, nº 35, 143-158.

. O judiciário frente à divisão dos poderes: um princípio em decadência?, Revista Trimestral de Direito Público, nº 9, 1995, p. 40-48.

FERREIRA FILHO, Manoel Gonçalves. Estado de direito e Constituição, $4^{\mathrm{a}}$ ed., São Paulo: Saraiva, 2007.

FIGUEIREDO, Lúcia Valle. Curso de direito administrativo, $8^{\mathrm{a}}$ ed., São Paulo: Malheiros, 2006.

FIORINI, Bartolomeu A. Manual de derecho administrativo, 2 vols., Buenos Aires: La Ley, 1968.

FLEINER, Fritz. Instituciones de derecho administrativo, Barcelona - Madri - Buenos Aires: Editorial Labor, 1933. 
FORSTHOFF, Ernst. Tratado de derecho administrativo, Madri: Instituto de Estudios Politicos, 1958.

FRANÇA, Phillip Gil. Ato administrativo e interesse público: gestão pública, controle judicial e consequencialismo administrativo, São Paulo: Revista dos Tribunais, 2013.

GABARDO, Emerson. Princípio constitucional da eficiência administrativa, São Paulo: Dialética, 2002.

GARCIA, Emerson (coord.). Discricionariedade administrativa, Rio de Janeiro: Lumen Juris, 2005.

GARCÍA-PELAYO, Manuel. Las transformaciones del Estado contemporáneo, Madri: Alianza Editorial, 1977.

GASPARINI, Diógenes. Direito administrativo, 14ª ed., São Paulo: Saraiva, 2009.

GENTOT, Michel. Les autoritès administratives indépendants, $2^{\mathrm{a}}$ ed., Paris : Montchrestien, 1994.

GIANNINI, Massimo Severo. Diritto amministrativo, $3^{\text {a }}$ ed., vols. I e II, Milão: Giuffrè, 1993.

GORDILlO, Agustín. Tratado de derecho administrativo, Tomo I, $7^{\mathrm{a}}$ Ed., Belo Horizonte: Del Rey, 2003.

GRAU, Eros Roberto. A ordem econômica na Constituição de 1988, 12a ed., São Paulo: Malheiros, 2007.

Ensaio e discurso sobre a interpretação/aplicação do Direito, $4^{\text {a }}$ ed., São Paulo: Malheiros, 2006.

O direito posto e o direito pressuposto, $6^{\mathrm{a}}$ ed., São Paulo:

Malheiros, 2005.

Por que tenho medo dos juízes (a interpretação/aplicação do direito e os princípios), $6^{\mathbf{a}}$ edição refundida do ensaio e discurso sobre a interpretação/aplicação do direito, São Paulo: Malheiros, 2013.

As agências, essas repartições públicas, in SALOMÃO FILHO,

Calixto (coord.). Regulação e Desenvolvimento, São Paulo: Malheiros, 2002, p. 25-28.

GUALAZZI, Eduardo Lobo Botelho, Justiça administrativa, São Paulo: Revista dos Tribunais, 1986.

GUERRA, Sérgio. Controle judicial dos atos regulatórios, Rio de Janeiro: Lumen Iuris, 2005. 
Discricionariedade e reflexividade: uma nova teoria sobre as escolhas administrativas, Belo Horizonte: Fórum, 2008.

Introdução ao direito das agências reguladoras, São Paulo: Freitas Bastos, 2004.

Direito administrativo e a nova hermenêutica: uma releitura do modelo regulatório brasileiro, Revista de Direito Administrativo, no 243, p. 168-207.

HAURIOU, Maurice. Précis de droit administratif et de droit public, $7^{\mathrm{a}}$ ed., Paris: Recueil Sirey, 1911.

JELLINEK, Georg. Reforma y mutación de la constitución, Madri: Centro de Estudios Constitucionales, 1991.

JUSTEN FILHO, Marçal. Concessões de serviços públicos (comentários às Leis $\mathbf{n}^{\mathbf{0}} \mathbf{s}$ 8.987 e 9.074, de 1995), São Paulo: Dialética, 1997.

Curso de direito administrativo, $9^{a}$ ed., São Paulo: Revista dos

Tribunais, 2013.

O direito das agências reguladoras independentes, São Paulo:

Dialética, 2002.

Teoria geral das concessões de serviços públicos, São Paulo:

Dialética, 2003.

LACHAUME, Jean-François; PAULIAT, Hélène; BRACONIER, Stéphane; DEFFIGIER, Clotilde. Droit administrative: Les grandes decisions de la jurisprudence, $15^{\mathrm{a}}$ ed., Paris: PUF, 2010.

LAUBADÈRE, André. Droit public économique, Paris: Dalloz, 1974.

; VENEZIA, Jean Claude; GAUDEMET, Yves. Droit administratif, tome I, 13 ${ }^{\text {a }}$ ed., Paris: LGDJ, 1994.

LEAL, Victor Nunes. Delegações legislativas, in Problemas de Direito Público, Rio de Janeiro: Forense, 1960, p. 92-108. . Lei e regulamento, in Problemas de Direito Público, Rio de Janeiro: Forense, 1960, p. 57-91. Os atos administrativos perante o Judiciário, in

Problemas de Direito Público, Rio de Janeiro: Forense, 1960, p. 256-277.

LONG, Marceau; WEIL, Prosper; BRAIBANT, Guy; DEVOLVÉ, Pierre; GENEVOIS, Bruno. Les grands arrêts de la jurisprudence administrative, $18^{\mathrm{a}}$ ed., Paris: Dalloz, 2011. 
LOPES, José Reinaldo de Lima. O oráculo de Delfos: o Conselho de Estado no Brasil-Império, São Paulo: Saraiva, 2010.

Raciocínio jurídico e economia. Revista de Direito Público da

Economia, $\mathrm{n}^{\mathrm{o}}$ 08, out./dez. 2004, versão digital, disponível em <http://www.bidforum.com.br/bid/PDI0006.aspx?pdiCntd=12790>. Acesso em: 02 setembro 2012

LORENZETTI, Ricardo Luís. Teoria da decisão judicial: fundamento de direito, São Paulo: Revista dos Tribunais, 2010.

LOWENSTEIN, Karl. Teoría de la constitución, $2^{a}$ ed., Barcelona: Editorial Ariel, 1976.

MAJONE, Giandomenico. Do Estado positivo ao Estado regulador: causas e consequências da mudança no modo de governança, in MATTOS, Paulo Todescan Lessa (coord.). Regulação Econômica e Democracia: O Debate Europeu, São Paulo: Singular, 2006, p. 53-85.

MARANHÃO, Juliano Souza de Albuquerque; AZEVEDO, Paulo Furquim; FERRAZ JÚNIOR, Tércio Sampaio Ferraz (coords.). Direito regulatório e concorrencial no Poder Judiciário, São Paulo: Singular, 2014.

MARQUES NETO, Floriano de Azevedo. A concessão como instituto do direito administrativo, Tese de Titularidade apresentada à Faculdade de Direito da Universidade de São Paulo, São Paulo, 2013.

Agências reguladoras independentes: fundamentos e seu regime jurídico, Belo Horizonte: Fórum, 2005.

Regulação estatal e interesses públicos, São Paulo: Malheiros, 2002.

A nova regulação estatal e as agências independentes, in Carlos Ari Sundfeld (coord.), Direito Administrativo Econômico, $1^{\mathrm{a}}$ ed., $2^{\mathrm{a}}$ tir., São Paulo: Malheiros, 2002, p. 72-98.

. A nova regulação jurídica dos serviços públicos, Revista Eletrônica de

Direito Administrativo Econômico, no 1, disponível em www.direitodoestado.com.br.

A responsabilidade objetiva das concessionárias de serviço público. A jurisprudência do STF e o papel da doutrina, Revista de Direito Administrativo Contemporâneo, $n^{\circ}$ 0, maio/junho 2013, p. 15-30.

A superação do ato administrativo autista, in MEDAUAR, Odete; SCHIRATO, Vitor Rhein. Os Caminhos do Ato Administrativo, São Paulo: Revista dos Tribunais, 2011, p. 89-113. 
Discricionariedade e regulação setorial - $\mathrm{O}$ caso do controle dos atos de concentração por regulador setorial, in ARAGÃO, Alexandre Santos de (coord.). O Poder Normativo das Agências Reguladoras, $2^{\text {a }}$ Ed., Rio de Janeiro: Forense, 2011, p. $427-453$.

Limites à abrangência e à intensidade da regulação estatal. Revista Eletrônica de Direito Administrativo Econômico, no 4, nov/dez 2005, jan/2006, disponível em www.direitodoestado.com.br, acesso em 09.09.2010.

- Os grandes desafios do controle da Administração Pública, in

MODESTO, Paulo (coord.). Nova Organização Administrativa Brasileira, 2a ed., Belo Horizonte: Fórum, 2010, p. 199-238.

. Pensando o controle da atividade de regulação estatal, in GUERRA, Sérgio (coord.). Temas de Direito Regulatório, Rio de Janeiro: Freitas Bastos, 2004, p. 200-248.

Poderes da Administração Pública, in FIGUEIREDO, Marcelo (coord.).

Novos Rumos para o Direito Público: Reflexões em Homenagem à Professora Lúcia Valle Figueiredo, Belo Horizonte: Fórum, 2012, p. 221-236.

. Princípios da proporcionalidade e da legalidade na regulação estatal,

Revista de Direito Administrativo, no 232, p. 368-397.

MATTOS, Paulo Todescan Lessa. O novo Estado regulador no Brasil: eficiência e legitimidade, São Paulo: Singular, 2006.

MEDAUAR, Odete. Controle da administração pública, São Paulo: Revista dos Tribunais, 1993.

Direito administrativo moderno, $17^{\mathrm{a}}$ Ed., São Paulo: Revista dos

Tribunais, 2013.

O direito administrativo em evolução, $2^{\mathrm{a}}$ ed., São Paulo: Revista dos Tribunais, 2003.

MEDIDA, José Miguel Garcia; ARAÚJO, Fábio Caldas de. Mandado de segurança individual e coletivo: comentário à Lei 12.016, de 7 de agosto de 2009, São Paulo: Revista dos Tribunais, 2009.

MEIRELLES, Hely Lopes. Direito administrativo brasileiro, $14^{\mathrm{a}}$ ed., São Paulo: Revista dos Tribunais, 1989.

MENDES, Gilmar Ferreira; COELHO, Inocêncio Mártires; BRANCO, Paulo Gustavo Gonet. Curso de Direito Constitucional, São Paulo: Saraiva, 2007. 
MESTRE, Jean-Louis, Introduction historique au droit administratif français, Paris: PUF, 1985.

MODESTO, Paulo. Notas para um debate sobre o princípio da eficiência. Revista Trimestral de Direito Público, vol. 31, 2000, p. 47-55.

MONTESQUIEU, Charles de Secondant, Baron de. De l'espirit des lois, Paris: Garnier Frères, Libraires-Éditeurs, s.d.

MORAES, Alexandre de. Agências reguladoras, in Agências Reguladoras, São Paulo: Atlas, 2002, p. 13-38.

MORAES, Germana Oliveira de. Controle jurisdicional da Administração Pública, $2^{a}$ ed., São Paulo: Dialética, 2004.

MOREIRA, Egon Bockmann. Processo administrativo: princípios constitucionais e a lei 9.784/1999, $4^{\text {a }}$ ed., São Paulo: Malheiros, 2010.

MOREIRA, Vital. A auto-regulação profissional e a administração pública, Almedina: Coimbra, 1997.

MAÇÃS, Fernanda. Autoridades reguladoras independentes: estudo e projecto de lei-quadro, Coimbra: Coimbra Editora, 2003.

MOREIRA NETO, Diogo de Figueiredo. Direito regulatório, Rio de Janeiro: Renovar, 2003.

Legitimidade e discricionariedade, $3^{\mathrm{a}}$ ed., Rio de Janeiro: Forense, 1998.

Mutações do direito administrativo, $3^{\text {a }}$ Ed., Rio de Janeiro: Renovar, 2007.

MORENO, Fernando Díez. El estado social, Madri: Centro de Estudios Políticos y Constitucionales, 2004.

NALINI, José Renato. O Poder Judiciário na Constituição de 1988, in Ives Gandra da Silva Martins et alli, Tratado de Direito Constitucional, vol. 1, São Paulo: Saraiva, 2010, p. 952-989.

NOBRE JÚNIOR, Edilson Pereira. Administração pública e o princípio constitucional da eficiência. Revista de Direito Administrativo, nº 241, jul./set. 2005, 209-240.

NONET, Philippe; SELZNICK, Philip. Law and society in transition: toward responsive law, $2^{\mathrm{a}}$ ed., $2^{\mathrm{a}}$ reimp., New Burnswick: Transaction Publishers, 2005.

OLIVEIRA, José Roberto Pimenta. Os princípios da razoabilidade e da proporcionalidade no direito administrativo brasileiro, São Paulo: Malheiros, 2006. 
ORTIZ, Gaspar Ariño. De la empresa pública a la empresa com participación pública: privatización o reforma? Quizas ambas cosas, in Revista de Administración Pública, n. 138, set./dez. 1995, p. 07-36.

Sobre la naturaleza y razón de ser de los entes regladores y el alcance de su poder reglamentário, Revista Eletrônica de Direito Administrativo Econômico, $\mathrm{n}^{\circ}$ 10, disponível em www.direitodoestado.com.br.

OTERO, Paulo. Legalidade e administração pública: o sentido da vinculação administrativa à juridicidade, Coimbra: Almedina, 2003.

OVIEDO, Carlos Garcia. Derecho administrativo, 2 vols., Madri: E.I.S.A., 1955.

PALMA, Juliana Bonacorsi de. Atividade normativa da Administração Pública. Estudo do processo administrativo normativo, Tese de Doutorado apresentada para a Faculdade de Direito da Universidade de São Paulo, São Paulo, 2014.

PEREIRA, César Augusto Guimarães. Usuários de serviços públicos: usuários, consumidores e os aspectos econômicos dos serviços públicos, $2^{a}$ ed., São Paulo: Saraiva, 2008.

PINTO, Bilac. Regulação efetiva dos serviços de utilidade pública, $2^{a}$ ed. (revista e atualizada por Alexandre Santos de Aragão), Rio de Janeiro: Forense, 2002.

PIRES, Luis Manuel Fonseca. Controle judicial da discricionariedade administrativa, Rio de Janeiro: Campus, 2008.

QUEIRÓ, Afonso Rodrigues. A teoria do "desvio de poder" em direito administrativo, Revista de Direito Administrativo, $n^{\circ}$ 06, p. 41-78.

Os limites do poder discricionário das autoridades administrativas,

Revista de Direito Administrativo, no 97, jul./set. 1969, p. 1-8.

RAMOS, Elival da Silva. Ativismo judicial: parâmetros dogmáticos, São Paulo: Saraiva, 2010.

ROCHA, Jean Paul Cabral Veiga da. Regulação econômica e separação de poderes: a delegação legislativa na tradição do direito público brasileiro, in ARAGÃO, Alexandre Santos de (coord.) Revista de Direito da Associação dos Procuradores do Novo Estado do Rio de Janeiro, vol XI - Direito da Regulação, Rio de Janeiro: Lumen Juris, 2002, p. 69-87.

RODRIGUEZ, José Rodrigo; NOBRE, Marcos. Judicialização da política? Sobre a naturalização da separação de poderes (I), in RODRIGUEZ, José Rodrigo. Como decidem as cortes? Para uma crítica do direito (brasileiro), Rio de Janeiro: FGV Editora, 2013, p. 177-199. 
ROSILHO, André. A constituição de 1988 e suas políticas em quatro atos, in SUNDFELD, Carlos Ari e ROSILHO, André (coord.), Direito da Regulação e Políticas Públicas, São Paulo: Malheiros, 2014, p. 17-43.

SAINT GIRONS, Antoine de. Essai sur la séparation des pouvoirs dans l'orde politique, administratif et judiciaire, Paris: L. Larouse, 1881.

SALOMÃO FILHO, Calixto. Regulação da atividade econômica (princípios e fundamentos jurídicos), São Paulo: Malheiros, 2001.

SCHIRATO, Vitor Rhein. A regulação para os serviços públicos como instrumento para o desenvolvimento, in Interesse Público, n. 30, mar./abr. 2005, 77-97.

As agências reguladoras independentes e alguns elementos da Teoria Geral do Estado, in ARAGÃO, Alexandre Santos de; MARQUES NETO, Floriano de Azevedo. Direito Administrativo e Seus Novos Paradigmas, Belo Horizonte: Fórum, 2008, p. 469-537.

O processo administrativo como instrumento do Estado de Direito e da Democracia, in MEDAUAR, Odete; SCHIRATO, Vitor Rhein (org.) Atuais Rumos do Processo Administrativo, São Paulo: Revista dos Tribunais, 2010, p. 9-51.

SHAPIRO, Martin. Who guards the guardians? Judicial control of administration, Georgia: University of Georigiua Press, 1988.

SILVA, Almiro do Couto e. Poder discricionário no direito administrativo brasileiro, Revista de Direito Administrativo, nº 179/180, jan./jun. 1990, p. 51-92.

SILVA, Luís Virgílio Afonso da. O proporcional e o razoável, Revista dos Tribunais, no 798, p. 23-50.

Princípios e regras: mitos e equívocos acerca de uma distinção, Revista

Latino-Americana de Estudos Constitucionais, nº 1, 2003, p. 607-630.

SOUTO, Marcos Juruena Villela. Direito administrativo regulatório, $2^{\mathrm{a}}$ ed., Rio de Janeiro: Lumen Juris, 2005.

As agências reguladoras e os princípios constitucionais, in

Direito Administrativo em Debate $2^{a}$ Série, Rio de Janeiro: Lumen Juris, 2007, p. 3957.

STASSINOPOULOS, Michel. Traité des actes administratifs, Paris: LGDJ, 1973 [reimp. da edição de 1954].

SUNDFELD, Carlos Ari. Administração e justiça: um novo equilíbrio?, in

Direito Administrativo para Céticos, $2^{a}$ ed., São Paulo: Malheiros, 2014, p. 317-340. 
Crítica à doutrina dos princípios do direito administrativo, in

Direito Administrativo para Céticos, $2^{a}$ ed., São Paulo: Malheiros, 2014, p. 179-203.

Motivação do ato administrativo como garantia dos administrados,

Revista de Direito Público, no 75, jul./set. 1985, p. 118-127.

Princípio é preguiça?, in

Direito Administrativo para

Céticos, $2^{\text {a }}$ ed., São Paulo: Malheiros, 2014, p. 205-229.

Processo administrativo: um diálogo necessário entre Estado e cidadão, in Revista de Direito Administrativo e Constitucional, nº 23, jan./mar. 2006,

$\begin{array}{llll}\text { versão } & \text { digital, } & \text { disponível }\end{array}$ http://www.bidforum.com.br/bid/PDI0006.aspx?pdiCntd=34582. Acesso em: 29 maio 2012.

Introdução às agências reguladoras, in

(Coord.). Direito

Administrativo Econômico, $1^{a}$ ed., $2^{a}$ tir., São Paulo: Malheiros, 2002, p. 17-38.

; CÂMARA, Jacintho de Arruda. O dever de motivação na edição de atos normativos pela Administração Pública, Revista de Direito Administrativo e Constitucional, $\quad \mathrm{n}^{\mathrm{o}} \quad 45, \quad$ jul./set. $\quad 2011, \quad$ disponível $\quad$ em http://www.bidforum.com.br/bid/PDI0006.aspx?pdxCntd=74840, $\quad$ acesso $\quad$ em 30.05.2012.

; ROSILHO, André. Direito e políticas públicas: dois mundos?, in Direito da Regulação e Políticas Públicas, São Paulo: Malheiros, 2014, p. 4579.

TÁCITO, Caio. Abuso de poder administrativo no Brasil (conceito e remédios), Rio de Janeiro: Departamento Administrativo do Serviço Público e Instituto Brasileiro de Ciências Administrativas, 1959.

Agências reguladoras da administração, Revista de Direito Administrativo, $\mathrm{n}^{\mathrm{o}} 221,2000$, p. 1-5.

As delegações legislativas e o poder regulamentar, in Temas de

Direito Público, $1^{\circ}$ vol., Rio de Janeiro: Renovar, 1997, 507-510.

As empresas estatais no direito brasileiro, in Temas de Direito

Público, $1^{\circ}$ vol., Rio de Janeiro: Renovar, 1997, 679-690.

. Comissão de Valores Mobiliário. Poder regulamentar, in Temas

de Direito Público, 2º vol., Rio de Janeiro: Renovar, 1997, p. 1.075 a 1.093.

Interpretação da norma administrativa. Métodos. Analogia. Equiidade, in

Temas de Direito Público, $1^{\circ}$ vol., Rio de Janeiro: Renovar, 1997, p-. 497-505. 
TEUBNER, Gunther. Le droit: un systhéme autopoietique, Paris: PUF, 1993.

VALENTE, Patrícia Pessôa. Análise de impacto regulatório: uma ferramenta à disposição do Estado, Belo Horizonte: Fórum, 2013.

VERÍSSIMO, Marcos Paulo. Aproximação sistemática ao controle judicial das agências de regulação econômica no Brasil, Dissertação de Mestrado, Faculdade de Direito da Universidade de São Paulo: São Paulo, 2002.

Controle judicial da atividade normativa das agências reguladoras brasileiras, in ARAGÃO, Alexandre Santos de (coord.). O Poder Normativo das Agências Reguladoras, $2^{\text {a }}$ Ed., Rio de Janeiro: Forense, 2011, p. 283-313.

WOLFE, Christopher. The rise of modern judicial review. From constitutional interpretation to judge-made Law, Revised Edition, Maryland: Littlefield Adams Quality Paperbacks, 1994.

ZANOBINI, Guido. Corso di diritto amministrativo, vol. I, $8^{\mathrm{a}}$ ed., Milano: Giuffrè, 1958.

ZIPPELIUS, Reinhold. Teoria geral do Estado, $3^{a}$ ed., Lisboa: Fundação Calouste Gulbenkian, 1997. 